\author{
UNIVERSIDADE DE SÃO PAULO \\ FACULDADE DE FILOSOFIA, LETRAS E CIÊNCIAS HuMANAS \\ DePARTAMENTO DE CIÊNCIA POLÍTICA
}

GRAZIELE SILOTTO

A DIMENSÃo REGIONAL DAS ESTRATÉGIAS PARTIDÁRIAS EM ELEIÇÕES PROPORCIONAIS DE LISTA ABERTA NO BRASIL

SÃO PAULO

2016 
GRAZIELE SILOTTO

\section{A DIMENSÃO REGIONAL DAS ESTRATÉGIAS PARTIDÁRIAS EM ELEIÇÕES PROPORCIONAIS DE LISTA ABERTA NO BRASIL}

Dissertação apresentada à Faculdade de Filosofia, Letras e Ciências Humanas da Universidade de São Paulo para obtenção do Título de Mestre em Ciência Política.

Orientador: Prof. Dr. Glauco Peres da Silva

SÃo PAULO

2016 
Nome: SILOTTO, Graziele

Título: A dimensão regional das estratégias partidárias em eleições proporcionais de lista aberta no Brasil

Dissertação apresentada à Faculdade de Filosofia, Letras e Ciências Humanas da Universidade de São Paulo para obtenção do Título de Mestre em Ciência Política.

Orientador: Prof. Dr. Glauco Peres da Silva

Aprovada em:

Banca examinadora

Prof. Dr.

Instituição:

Julgamento:

Assinatura:

Prof. Dr.

Instituição:

Julgamento:

Assinatura:

Prof. Dr.

Instituição:

Julgamento:

Assinatura: 
Aos meus pais, Maria e Onivaldo 


\section{Agradecimentos}

É difícil sintetizar a gratidão que sinto para com tantas pessoas que me acompanharam nessa trajetória de um aprendizado que vai muito além das páginas deste trabalho. $\mathrm{O}$ caminho que me trouxe até aqui começou em 2011, quando tive o privilégio de começar a trabalhar no Centro de Estudos da Metrópole. Andreza, agradeço a oportunidade que você e o Danilo me deram, e todo o aprendizado que você, pacientemente, me passou. Agradeço também à Lara Mesquita, com quem também tive o prazer de trabalhar e aprender a fazer meus mapinhas.

À Glauco Peres da Silva, meu orientador, com quem eu tinha medo de falar no ido 2012, mas com quem hoje eu tenho prazer de dividir meu trabalho, angústias e alegrias da vida. Glauco, sua fama de melhor orientador não surgiu por acaso, e sou em grande parte culpada por ela - e continuarei sendo! Sou muito agradecida pelos conselhos de "pai-Glauco", por poder aprender e trabalhar com você em todos esses anos. Espero que a nossa parceria acadêmica e na vida perdure por muito tempo. Hoje vejo em você não só muita qualidade profissional, mas uma inspiração e um amigo de porta sempre aberta, seja para tomar um cafezinho e jogar conversa fora, seja para quando "não sei o que fazer da minha vida, e agora!" e, em meia hora de conversa, saio com a alma leve e um sorriso no rosto. Agradeço a confiança no meu trabalho, a paciência e o carinho de sempre.

Danilo, você é um caso à parte. $\mathrm{O}$ tempo me fez ver em você muito mais que o moço engraçado do Cebrap, da namorada feminista do sorriso lindo, Ana. Te tenho como um amigo a quem recorro, mesmo à distância, quase que diariamente. Sinto sua falta sempre que chego no Neci e sei que ninguém vai me chamar de Bip, ou cantarolar o dia todo. Sinto falta dos cafés da tarde, junto com o Maurício, meu japonês preferido, e Patrick, meu nerd preferido. Maurício, agradeço pela prontidão em ajudar, e pelo coração enorme que você, às vezes, tenta esconder com poucas palavras. Patrick, obrigada pela companhia, conselhos e pelas risadas de longa data. Com você sempre tenho conversas instigantes sobre a vida, a academia, ou qualquer outra coisa. Sinto um carinho enorme por você, e te desejo toda a felicidade desse mundo.

Agradeço também aos demais amigos que o Cebrap, o CEM e o Neci me trouxeram. Ao Samir e ao Cássio, pela fofura de sempre. À Fernanda e à Mini Andrea pelas risadas e o 
apoio. Agradeço também os mais jovens (que são muitos!) pela companhia animada nos dias de trabalho: Ana, Ligiane, Vanessa, Isa, Leo, Giovana, Gabriel Z., Nathan e Bianca. Ao Nathan e Bianca agradeço ainda pela ajuda com parte dos dados deste trabalho. Ao Paulo Hubert, sempre tão atencioso e pronto pra ensinar complexidades aos empiristas vulgares. Também ao Flávio, gran fiesta, que contagia com sua alegria as festas do Neci. À Celi, sem a qual o Neci não existiria. E mais recentemente, ao Pedro, por partilhar a curiosidade sobre os mistérios do universo.

Andrea Freitas, a paixão que você tem pelo que faz é inspiradora! Minha companheira de discutir GoT, Harry Potter, ou qualquer outra coisa, foi e é um imenso prazer aprender e trabalhar com você. Descobri com o tempo que por trás de tanta dedicação, e fones de ouvido na escrita da tese, tem uma mulher carinhosa, preocupada e muito especial. Anseio pelos dias que você vem ao Neci! Agradeço profundamente o carinho, a atenção e o aprendizado.

Joyce e Ju, pra vocês, mal tenho palavras. Hoyce, você esteve presente em toda essa trajetória, me segurando a mão, com o coração e os braços abertos para rir ou chorar. Você está presente em cada uma dessas páginas. Ju, miga, te encontrar foi um presente do universo. Obrigada pelo apoio, pelos conselhos, por me emprestar os ombros e por me ensinar a me amar cada vez mais. A amizade de vocês quero levar para toda a vida. Agradeço ainda à Mari, que chegou de mansinho, e já faz parte disso tudo. Mari, obrigada por me inspirar coisas tão boas (e agradeça ao Reynaldo da CDHU pela ajuda mágica com o ArcGis!). Migas, gratidão pelo grupo e pelo carinho que me dá forças pra seguir em frente, sempre.

Agradeço também ao professor Fernando Limongi pela oportunidade, pela orientação provisória e pelos ensinamentos despretensiosos. À professora Maria do Socorro S. Braga, pelas sugestões na minha banca de qualificação. Ao Guarnieri, pela leitura e pelas ideias que me impressionam mais a cada encontro. Agradeço também ao professor Adrian Lavalle, por uma das melhores disciplinas que me guiaram até aqui.

Pela companhia nas listas de métodos e na vida, agradeço aos amigos de mestrado: Stefania, Thiago Meirelles, Vitor Diniz e Thiago Moreira, um doce de pessoa. Também à Dani Constanzo, a quem agradeço pela fofura e o ombro amigo. Pelas palavras de incentivo, pelo apoio, de perto e de longe, e pelas ótimas influências musicais, agradeço ao Thiago Nascimento, meu queridão mais querido! Aos amigos de corredor, sem os 
quais a vida seria mais quieta e o trabalho mais solitário. Vocês tornam o DCP um lugar onde me sinto muito à vontade. À Bruno Pessoa, pela amizade e pelas conversas no trajeto USP - Consolação. Às amigas do DCP que dão cor e talento à academia, tão masculina: Hannah, Bia, Natália Moreira, Gabi Rosa, Lilian querida, e Marina Merlo. Má, a menina descolada do orkut-2008, que prazer é dividir o caminho (e o orientador) com você! Gui Zanelatto, obrigada pelo carinho apesar do tempo e da distância. Agradeço ainda ao Grupo do Estudos Eleitorais, pelas manhãs de quartas de muito aprendizado e a companhia.

Pelo apoio institucional agradeço aos funcionários e amigos do departamento, Rai, Vasne e Márcia. Agradeço à Capes pela bolsa concedida, sem a qual essa pesquisa não seria possível.

Aos amigos de casa. À Cá, Ingrid, Mari, Anjo e Zé, por todos esses sete anos incríveis e pelo lar tão acolhedor, sempre. Agradeço pela paciência, pelas comemorações, pelos abraços sempre abertos e o apoio. Vocês são a família que eu escolhi partilhar a minha vida. Meu carinho por vocês transborda! Agradeço ao $\mathrm{Gu}$, companheiro na valentia contra animais selvagens na cozinha. E também à recém chegada Rochele, pela companhia e as risadas durante as noites e as leituras.

Agradeço, por fim, à melhor família que eu poderia ter. À Michele, a irmã que me foi dada pela tia $\mathrm{Lu}$, minha segunda mãe. Mi, minha risada mais gostosa é sua (e o leite do meu sucrilhos também). Também ao Tio Celso e ao Bruno. Meus fins de semana são muito mais divertidos com vocês. É tanto carinho que nem cabe no peito. Ofereço estas páginas em memória da minha avó Josefa, que se foi antes dessa jornada começar, mas que sempre me visitou nos meus sonhos.

Aos meus pais, Maria e Onivaldo, que me despertaram a curiosidade por política e a minha vontade de aprender. Obrigada por me proporcionar a oportunidade que vocês nunca tiveram, além do apoio, da admiração e confiança que vocês têm em mim. Vocês são os responsáveis por eu ter chegado até aqui. À vocês devo tudo, e dedico este trabalho com todo o meu amor. 


\section{RESUMO}

SILOTTO, Graziele. (2016). A dimensão regional das estratégias partidárias em eleições proporcionais de lista aberta no Brasil. Dissertação de Mestrado. Faculdade de Filosofia, Letras e Ciências Humanas, Universidade de São Paulo, São Paulo.

Este trabalho aborda a questão regional enquanto uma estratégia dos partidos na arena eleitoral. Ao acrescentar a dimensão partidária aos trabalhos que advogam pela regionalização dos distritos eleitorais de elevada magnitude, o intuito foi mostrar que é do sistema eleitoral, sobretudo da lista aberta, da magnitude e da estrutura da competição que emanam os incentivos à subdistritalização. Como uma perspectiva teórica alternativa à solução distributivista, o argumento é que o sistema eleitoral traz o elemento regional ao plano das decisões partidárias, isto é, a subdistritalização ocorreria em decorrência da ação intencional política que, com isso, garantiria a diminuição ou a ausência da competição intrapartidária no território. O resultado da análise da lista de candidatos brasileira reforça que o meio social e o político respondem aos fatores regionais, que influencia suas atitudes e estratégias. Por meio de uma dinâmica não política, mas geoespacial partidos encontram estratégias para lidar com as restrições institucionais a fim de atingir o sucesso eleitoral.

Palavras-chave: estratégias partidárias, partidos, competição intrapartidária, lista de candidatos, geografia eleitoral 


\begin{abstract}
SILOTTO, Graziele. (2016). The regional dimension of the partisan strategy in open list proportional elections in Brazil. Dissertação de Mestrado. Faculdade de Filosofia, Letras e Ciências Humanas, Universidade de São Paulo, São Paulo.

This thesis considers the regional question as a partisan strategy in the electoral arena. The goal is to show that from the electoral system, especially the open list proportional representation, the magnitude and the structure of the electoral competition, emanates the incentives for subdistricting. Therefore, partisanship is introduced, adding a new dimension to the scholarship that advocates for the regionalization of the high magnitude districts. When arguing that, in fact, parties' decisions are influenced by regional elements which were fostered by the electoral system, this study pursues an alternative theoretical perspective to distributivism. Subdistricting is a byproduct of intentional political action, which, in turn, ensures the decrease or absence of intra-party competition over the territory. The findings - based on the analysis of the list of candidates presented by parties in Brazil - reinforces that the social and political environment responds to regional factors that influence their attitudes and strategies. Through a non-political, but geospatial dynamic, parties can strategically deal with the institutional constraints in order to achieve electoral success.
\end{abstract}

Keywords: party strategies, parties, intraparty competition, list of candidates, electoral geography 


\section{Lista de gráficos}

Gráfico 1 - \% de candidatos lançados em relação ao permitido por UF por ano, ordenados pela magnitude dos distritos, da menor para a maior 66

Gráfico 2 - Posição do candidato na lista geral do partido e na sua respectiva região PFL/DEM

Gráfico 3 - Posição do candidato na lista geral do partido e na sua respectiva região -

PMDB

Gráfico 4 - Posição do candidato na lista geral do partido e na sua respectiva região $\mathrm{PPB} / \mathrm{PP}$

Gráfico 5 - Posição do candidato na lista geral do partido e na sua respectiva região - PT

Gráfico 6 - Posição do candidato na lista geral do partido e na sua respectiva região -

PSDB

Gráfico 7 - Posição do candidato na lista geral do partido e na sua respectiva região PSD. 


\section{Lista de Tabelas}

Tabela $1-\%$ de cadeiras dos cinco partidos nacionais mais votados. 68

Tabela 2 - \% de Cadeiras e Candidatos Lançados Pelos 5 Maiores Partidos Nacionais em SP

Tabela 3 - Níveis de hierarquia dos municípios brasileiros - Regic/IBGE ................... 71

Tabela 4 - Rede Urbana - São Paulo e População ........................................................... 74

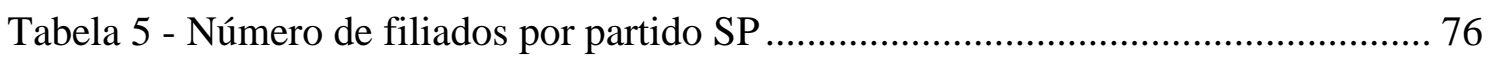

Tabela 6 - \% dos candidatos lançados encontrados na base de filiados em SP.............. 77

Tabela 7 - Candidatos a deputado federal dos partidos analisados com Passado Político Local 78

Tabela 8 - Magnitude eleitoral das Regiões de SP dado seu eleitorado 80

Tabela 9- Quociente Eleitoral - SP $(\mathrm{M}=70)$ e Corte do QE para Candidatos

Competitivos 93 


\section{Lista de Mapas}

Mapa 1 - A rede de municípios do estado de São Paulo ................................................. 73

Mapa 3 - Mapa da magnitude eleitoral das Regiões de SP dado seu eleitorado ............. 81

Mapa 4 - Alocação regional de candidatos do PFL/DEM entre 2002 e 2010 ................. 84

Mapa 5 - Alocação regional de candidatos do PMDB entre 2002 e 2014 ...................... 85

Mapa 6 - Alocação regional de candidatos do PPB/PP entre 2002 e 2014 .................... 87

Mapa 7 - Alocação regional de candidatos do PT entre 2002 e 2014 ............................ 88

Mapa 8 - Alocação regional de candidatos do PSD em 2014 ......................................... 89

Mapa 9 - Alocação regional de candidatos do PSDB entre 2002 e 2014 ........................ 90

Mapa 10 - Alocação regional de candidatos competitivos do PFL/DEM entre 2002 e 2010

Mapa 11 - Alocação regional de candidatos competitivos do PMDB entre 2002 e 2014

Mapa 12 - Alocação regional de candidatos competitivos do PPB/PP entre 2002 e 2014 96

Mapa 13 - Alocação regional de candidatos competitivos do PT entre 2002 e 2014..... 98

Mapa 14 - Alocação regional de candidatos competitivos do PSD entre 2002 e 2014 .. 99

Mapa 15 - Alocação regional de candidatos competitivos do PSDB entre 2002 e 2014 


\section{SUMÁRIO}

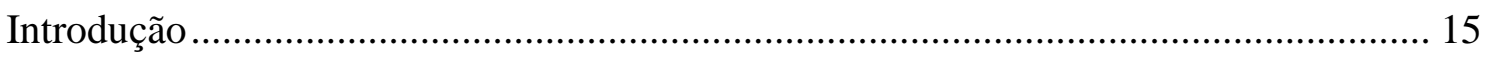

Capítulo 1 - Os múltiplos incentivos da arena eleitoral ............................................ 20

1.1 - Incentivos do sistema eleitoral: a lista aberta ................................................. 22

1.2 - Incentivos da legislação e os partidos enquanto agentes da decisão .................. 25

1.3 - Incentivos eleitorais: coordenação “estratégica" partidária............................... 29

1.4 - Incentivos eleitorais: magnitude, distritos e regionalização ............................. 31

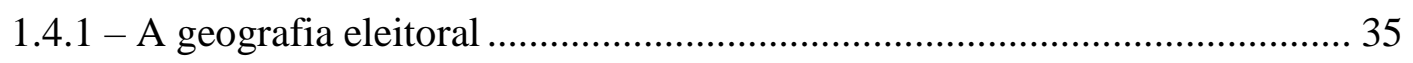

1.4.2 - Estratégias partidárias sob a perspectiva da geografia eleitoral ................ 39

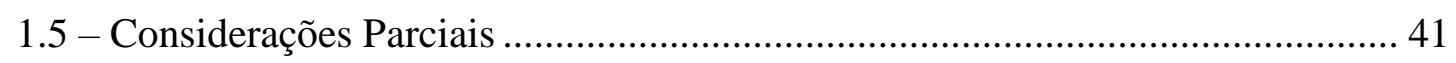

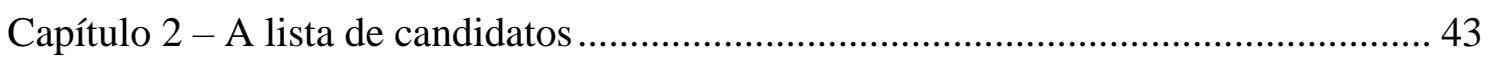

2.1 - O debate internacional sobre a seleção de candidatos e recrutamento ............... 45

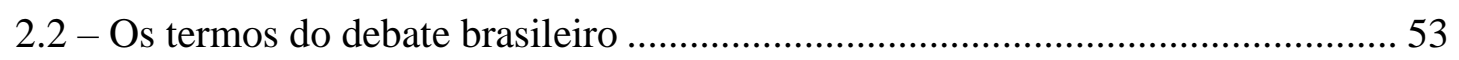

2.2.1 - O Recrutamento Político e Seleção de Candidatos no Brasil ...................... 53

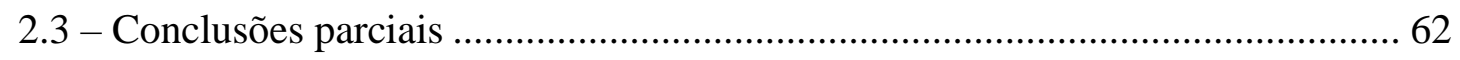

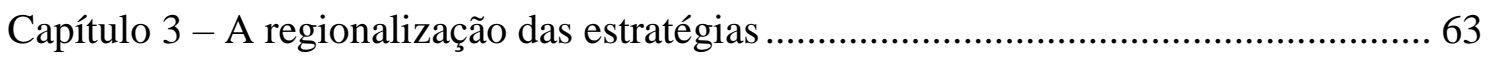

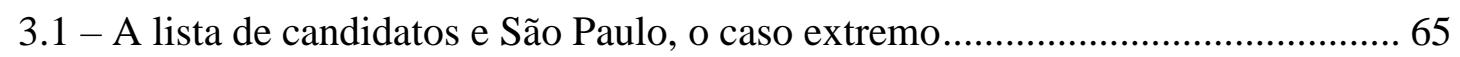

3.2 - A dinâmica regional: definindo as regiões ...................................................... 70

3.2.1 - A rede de São Paulo ......................................................................... 72

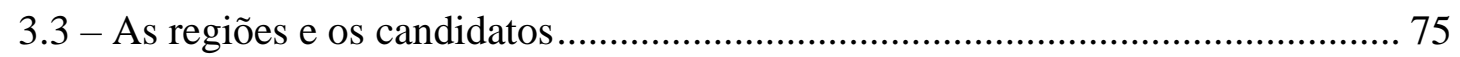

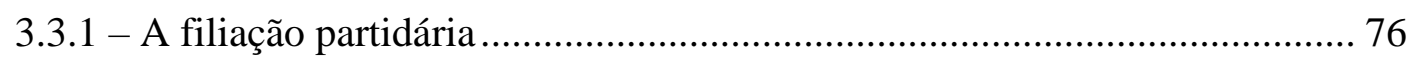

3.3.2 - O passado político local....................................................................... 77

3.3.3 - O candidato político local e a alocação regional ..................................... 79

3.4 - Como partidos alocam seus candidatos regionalmente? .................................. 83

3.5 - Mas candidatos regionais são mais votados em suas regiões? ....................... 102

3.6 - Considerações Parciais ............................................................................... 110

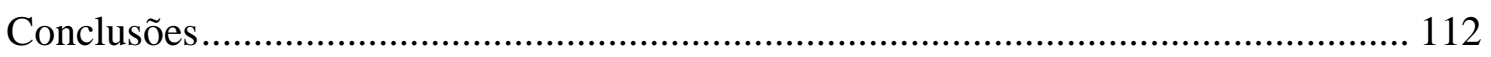

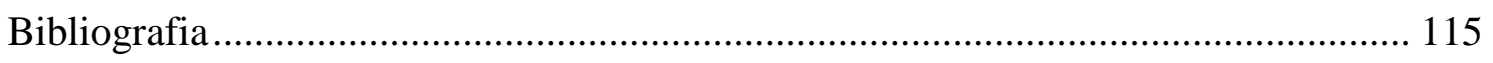

Anexo 1 - Magnitudes dos distritos brasileiros ....................................................... 124

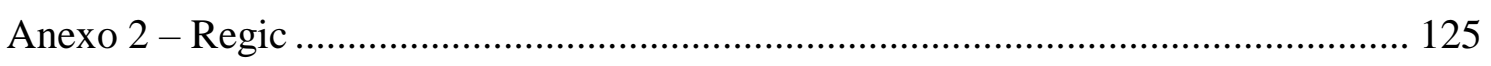

Anexo 3 - Número de candidatos alocados na lista por partido e por região de acordo com local de filiação.................................................................................. 128 
Anexo 4 - Número de candidatos alocados na lista por partido e por região de acordo

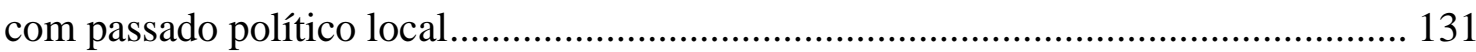

Anexo 5 - Regic: fluxo informacional e fluxo de pessoas

Anexo 6 - Número de candidatos competitivos alocados na lista por partido e por região

Anexo 7 - Região do candidato de acordo com a sua posição na lista do partido por região 


\section{INTRODUÇÃO}

Estudos contemporâneos sobre a arena eleitoral brasileira têm se preocupado em compreender o papel dos partidos na organização do processo eleitoral e seu comportamento nas eleições em si. Estes trabalhos partem do pressuposto que partidos são, conforme o paradigma da escolha racional postula, atores estratégicos. Como tal, eles visariam a maximização de seus interesses e objetivos. No caso, partidos agiriam com a finalidade de conquistar eleitores e votos como um meio para a obtenção de postos de representação.

Nesse cenário, essa literatura mais recente procura lançar luz sobre uma série de questões sobre as quais a Ciência Política brasileira tenta encontrar respostas. Há autores que se preocupam em compreender como se dá a organização interna dos partidos (e.g. Amaral \& Meneguello, 2010; Braga, 2008; Guarnieri, 2011, 2012; Ribeiro, 2013), outros investigam em profundidade os partidos brasileiros, sua história e seus movimentos (ver Amaral, 2013; Maciel, 2014; Meneguello, 1989; Mucinhato, 2015; Ribeiro, 2014; Roma, 2002; Terron \& Soares, 2010), há trabalhos sobre financiamento eleitoral (e.g. Cervi, 2010; Sacchet \& Speck, 2012; Speck \& Mancuso, 2014), representação de gênero e raça (e.g. Araújo, 2009; Praça, Freitas, \& Hoepers, 2012; Sacchet \& Speck, 2012), e uma infinidade de outros temas.

Essas novas pesquisas introduzem uma nova abordagem em relação a uma geração de trabalhos anteriores. Às análises, é acrescida a dimensão partidária, antes desconsiderada. Isto é, elas pressupõem que partidos têm relevância enquanto atores no processo eleitoral, em contraposição às abordagens que advogavam pelo esvaziamento das agremiações quanto ao papel de organizadoras da arena eleitoral. Se antes partidos brasileiros eram tratados como "máquinas de patronagem", fadados ao fisiologismo engendrado pelo arranjo eleitoral adotado (Ames, 2003; Lamounier, 1992; Mainwaring, 1991), agora são a unidade primordial da qual partem as pesquisas.

Dessa suposição da dimensão estratégica como intrínseca às organizações partidárias resulta que essas agremiações tomam decisões imersas num ambiente cercado de restrições que são instigadas pelos incentivos que emanam do sistema eleitoral brasileiro. É necessário, portanto, que os partidos assimilem esses incentivos para que 
possam atingir o sucesso eleitoral. Vários são os caminhos possíveis para a obtenção deste êxito. Alguns partidos optam pelo caminho da capilarização organizacional a fim de conquistar votos, como é o caso do PT (Davidian, 2013), outros investem na conquista de cargos locais para se fazer presente no imaginário do eleitor, como o PMDB. No geral, partidos adotam mais que uma estratégia ao mesmo tempo. De toda forma, ainda que diversas sejam as motivações estratégicas dos partidos, à todos eles são apresentadas restrições institucionais que procedem da legislação que rege as eleições com as quais eles tem que lidar.

Mas quais são essas restrições geradas pelos incentivos institucionais? À representação proporcional de lista aberta se atribuía a origem da deficiência e do desgoverno partidário. A centralidade do candidato conferida por esse sistema levaria agremiações à mingua, somada à elevada magnitude dos distritos, seria responsável pela formação de constituencies no interior dos distritos eleitorais que seriam seladas por relações fisiologistas, políticas distributivistas (Ames, 2003) e competição intrapartidária. Estas análises foram um sem número de vezes apontadas como insuficientes (c.f. Figueiredo \& Limongi, 2002), ou negligentes pela literatura recente que, crítica, passou a incorporar outras características prescritas pela legislação, como as prerrogativas que habilitam partidos a atuarem como atores elementares no processo eleitoral.

Há, entretanto, um elemento fundamental presente naquelas pesquisas que pouco tem sido tratado pelos trabalhos atuais. Hoje apontado apenas lateralmente, o componente regional que origina as constituencies estaria presente em qualquer sorte de sistema eleitoral, mesmo naqueles em que não há qualquer tipo de prescrição institucional formal para tal, como no caso da representação proporcional (Latner \& McGann, 2005). Nesse ínterim, o subtipo "lista aberta" sobreposto à distritos de magnitude elevada como os brasileiros - constituiria base para que estes territórios grandes se subdistritalizassem. Esse fator foi apontado por Ames (2003) sob a perspectiva distributivista, mas assume-se aqui que há outra motivação para tal fenômeno: a própria estrutura da competição originaria a opção regionalista por parte dos atores envolvidos.

Em outras palavras, a elevada magnitude dos distritos brasileiros levaria à regionalização dos distritos. Isso porque enquanto a dinâmica dos distritos uninominais é de um cenário no qual há um baixo número de candidatos que concorrem num distrito menor, a lógica é diferente para sistemas de magnitude alta, como o brasileiro. A dimensão territorial cria obstáculos em termos de custos financeiros e humanos para a 
promoção dos vários candidatos. Esses candidatos são postos num quadro em que o eleitorado de um distrito está espacialmente disperso e distante, o que se constitui como obstáculo real à conquista dos votos. Em virtude disso, seria a própria dinâmica da competição que levaria as campanhas a serem tratadas não em termos distritais - o que seria incongruente do ponto de vista racional-maximizador dados os custos que acarretaria -, mas em termos regionais.

Não obstante, a opção da regionalização, ao invés de uma consequência natural da estrutura da competição, pode ser antes parte de uma estratégia dos partidos. À luz da existência dos partidos enquanto agentes organizadores do processo eleitoral se pode assumir que essas agremiações coletivas poderiam assimilar esse efeito restritivo característico da magnitude elevada e se apropriar dessa dinâmica que propicia a subdistritalização. A partir da formulação de estratégias eleitorais regionais poderiam conquistar mais votos sob os menores custos. Isto é, partidos poderiam incorporar a regionalização como um elemento decisivo que baliza e influencia suas escolhas e, com isso, obter maiores chances de sucesso eleitoral. É este movimento partidário que esta pesquisa se propõe a verificar e analisar.

Nesse sentido, a formulação da lista de candidatos pode ser um primeiro momento em que o movimento estratégico é implementado. Por sua formulação ser uma prerrogativa exclusiva do partido, elas podem funcionar como uma "etapa de controle" na qual as lideranças partidárias atuam como coordenadoras estratégicas, formando listas otimizadas do ponto de vista eleitoral, o que pode garantir maiores chances de vitória aos partidos. A questão que se delineia, então, é que dado os incentivos eleitorais e as restrições que os partidos enfrentam, como eles lidam com a composição da sua lista de candidatos.

A resposta para esta questão passa por um duplo esforço. O primeiro estende-se sobre uma questão geográfica, isto é, encontrar uma definição de região que não seja formulada $a d$ hoc ou com base na dinâmica política em si, uma vez que a política está assentada sob estas divisões e não o contrário. A busca é por uma divisão regional que contemple a dinâmica geoespacial do mundo social e do mundo político. Já o segundo esforço é entrelaçar esse elemento espacial com a dimensão político-partidária, de forma que esta arena não política engendrada pelo mundo socioespacial, encontre-se refletida na lógica eleitoral, tornando possível a identificação de estratégias regionais na formação das listas por parte dos partidos. 
A presente pesquisa optou pelo uso de uma alternativa singular na Ciência Política. Ao analisar o caso extremo posto pelo argumento da centralidade do candidato em detrimento do partido enquanto agente organizador eleitoral, o caso do legislativo nacional do estado de São Paulo de magnitude $\mathrm{M}=70$ será explorado sob a perspectiva regional proposta pelo Instituto Brasileiro de Geografia e Estatística por meio do layer geoespacial proposto pela "Região de Influência das Cidades", a Regic. O intuito foi verificar e explorar se esta definição regional se refletia na arena político-eleitoral do ponto de vista partidário.

O capítulo 1 se voltará à discussão dos incentivos eleitorais subjacentes a essa discussão. Serão apresentados e discutidos os argumentos teóricos da literatura que identifica a representação proporcional de lista aberta como o elemento central do qual emanam incentivos aos atores políticos envolvidos: candidatos, políticos, partidos e eleitores. Depois serão apresentadas outras dinâmicas institucionais igualmente presentes no sistema eleitoral cujas consequências são apenas lateralmente dimensionadas por essa literatura. O papel institucional dos partidos, garantidos pela legislação, e o efeito da magnitude elevada dos distritos sobre os incentivos que levam à regionalização das estratégias será explorado. Por fim, uma discussão sobre como pesquisas da geografia eleitoral tratam a questão regional e lançam luz sobre a plausibilidade desse argumento sobre as estratégias partidárias fecham o quadro teórico das motivações que emergem do contexto institucional à esfera partidária.

O capítulo 2 se concentrará em mostrar como a literatura trata a questão da formação da lista de candidatos. Serão apresentados, em linhas gerais, os avanços e as respostas que pesquisas internacionais fazem sobre o tema da seleção de candidatos e o recrutamento partidário e como estes trabalhos incidem sobre a forma que se pesquisa e analisa estes mesmos fenômenos no Brasil. O diagnóstico que se delineia é que os avanços alcançados até agora, embora fundamentais, versam pouco sobre uma dimensão estratégica do uso da lista de candidatos por parte dos partidos. Alguns poucos trabalhos recentes sobre o Brasil apontam tal característica, ainda que não necessariamente investiguem-na. A proposta é, com base na extensa descrição fornecida pelos autores, avançar sobre este campo em que se abre uma primeira possibilidade de gerência tática do processo eleitoral por parte dos partidos.

O capítulo 3, por fim, tratará da dimensão analítica da estratégia regional na lista de candidatos partidária. Nele será empreendido o duplo esforço da identificação do quadro 
regional que será utilizado na análise e como o cenário político se comporta quando sobreposto neste enquadramento. O primeiro passo consistiu na identificação de um critério de desenho regional, no qual se privilegiou um elemento exógeno à arena política, e, posto isso, partiu-se para a identificação das estratégias partidárias frente à dinâmica regional. Neste passo, foi necessário encontrar meios de identificar candidatos de acordo com essas regiões, e buscar compreender como se dá a alocação regional.

Os resultados se mostraram promissores no sentido de reforçar que partidos não só podem agir como atores estratégicos, como o fazem quando essas estratégias são vistas sob o ângulo da perspectiva regional. A alocação regional dos candidatos mostrou que partidos encontram meios para contornar a competição intrapartidária. Além disso, que essa dinâmica regional tem reflexos também sobre decisão do eleitor, que privilegia os candidatos locais em detrimento dos demais.

Por fim, serão tratadas as conclusões finais, onde se retomará os argumentos tratados ao longo deste trabalho, bem como os resultados encontrados. Serão apontados, ainda, os múltiplos caminhos que se abrem a partir destes achados da pesquisa aqui desenvolvida. 


\section{CAPÍTULO 1 - OS MÚLTIPLOS INCENTIVOS DA ARENA ELEITORAL}

Das regras dos sistemas eleitorais emanam incentivos que incentivos que atores terão em um determinado sistema político e estes são responsáveis por moldar o comportamento de candidatos, líderes partidários, parlamentares, eleitores, entre outros. O presente capítulo pretende lançar luz sobre como a Ciência Política negligencia alguns incentivos do ponto de vista analítico ao focar sua atenção em outros. O objetivo será mostrar que os incentivos tradicionalmente apontados pela ciência político interagem com um conjunto maior de incentivos que atuam igualmente sobre a arena eleitoral.

Esse debate está aqui organizado, inicialmente, em torno desses incentivos institucionais que a literatura articula para derivar teorias sobre o funcionamento do sistema político brasileiro, sobretudo no que tange à arena eleitoral. Assim, primeiro será discutido como são interpretados os incentivos que emanam diretamente do sistema eleitoral adotado, acima de tudo aqueles derivados da representação proporcional de lista aberta. Em seguida, serão discutidos os incentivos ofertados aos partidos que são originados pela legislação eleitoral. O objetivo é mostrar que a despeito das motivações personalistas da lista aberta, a lei cria espaço para que partidos atuem incisivamente no processo (pré)eleitoral. Nesse ínterim, incentivos negligenciados pela literatura atuam em sentido contrário àqueles habitualmente explorados.

O passo seguinte consistirá em apontar que partidos não só exercem papel fundamental na organização eleitoral, como têm incentivos da própria dinâmica da competição para fazê-lo estrategicamente. Em outras palavras, têm prerrogativas exclusivas que geram uma "etapa de controle" do processo, permitindo que eles atuem como coordenadores estratégicos na formação das listas de candidatos porque é "o melhor a ser feito" do ponto de vista racional-maximizador, característica que lhes é assegurada pelo paradigma do neoinstitucionalismo da escolha racional.

Entretanto, a coordenação estratégica restrita ao plano político-eleitoral, a saber, a escolha de candidatos de acordo com as suas chances de sucesso eleitoral, não seria suficiente para contornar outra dimensão do problema lançado aos partidos pelo sistema e pela competição eleitoral: a disputa intrapartidária. O intuito será, portanto, mostrar 
como a estrutura da competição, os distritos e sua magnitude indicam que a adoção de estratégias regionalistas na resolução deste problema seja uma das mais eficientes. Os argumentos levantados pela geografia eleitoral, por fim, pretendem ajudar a elucidar teoricamente as razões pelas quais essas estratégias geográficas podem ajudar a driblar a dupla competição (intra e interpartidária) que candidatos enfrentam nas eleições. $\mathrm{O}$ contexto socioespacial que permeia o mundo social e cria fluxos de informações pode ajudar partidos a encontrar táticas de campanhas mais eficazes, contornando a questão da canibalização de candidaturas em seu interior. 


\section{1 - Incentivos do sistema eleitoral: a lista aberta}

As regras que regem os sistemas eleitorais são responsáveis por criar determinados incentivos que moldam o comportamento dos partidos, dos candidatos, políticos e eleitores. É com base nesses incentivos engendrados pela legislação eleitoral que são definidas e interpretadas as estratégias dos atores políticos. Em outras palavras, a ação desses atores dependeria, de acordo com a Ciência Política, de como está dado o arranjo institucional na arena eleitoral.

Em The personal vote, Cain, Ferejohn e Fiorina (1987, p. 214) apontaram que em sistemas em que eleitores escolhem candidatos individualmente há incentivos para o estabelecimento do voto de cunho pessoal. Por outro lado, se eleitores votam numa lista partidária pré-formulada, esses incentivos passam a ser fracos ou até inexistentes. De forma análoga, Carey e Shugart (1995) afirmaram que em sistemas de representação proporcional de lista aberta a reputação individual do candidato tem papel crucial na obtenção do sucesso eleitoral, em detrimento da reputação partidária como fiadora eleitoral - característica conferida aos sistemas de lista fechada.

Para estas interpretações, a centralidade da reputação pessoal na lista aberta seria consequência da possibilidade de escolha nominal dos candidatos pelos eleitores. Estar entre os mais votados estaria relacionado preponderantemente ao prestígio associado ao nome do candidato, e pouco relacionado com o partido ao qual ele pertence. Importaria para a obtenção do sucesso eleitoral, nesse sentido, o empenho e o vínculo que o candidato consegue estabelecer com o seu eleitorado, às custas de um vínculo baseado na centralidade partidária. A base do voto do eleitor teria um caráter personalista, em contraposição a um ideal de voto cunhado na identificação partidária.

Dada a grande importância da figura do candidato, políticas geograficamente localizadas seriam frequentemente utilizadas para alavancar as candidaturas frente ao eleitorado (Cain et al., 1987). Políticas distributivistas e constituency services seriam estratégias adotadas para impulsionar a figura do político frente ao eleitorado, que o recompensaria com votos levando-o a alcançar seu sumo objetivo: reeleger-se. A análise que articula a representação proporcional de lista aberta e o voto pessoal alavancado por 
políticas geograficamente localizadas no caso brasileiro foi concebida por Ames (1995, 2003) sob o conceito de conexão eleitoral ${ }^{1}$.

Nesse horizonte teórico, partidos teriam papel esvaziado. Serviriam apenas formalmente, no processo de registro e lançamento de candidaturas sem, contudo, controlá-los. Sem o papel efetivo das agremiações, poucas seriam as barreiras institucionais para o ingresso na lista de candidatos, e não haveria qualquer tipo de organização partidária da competição. Com um elevado número de candidatos que se baseiam na reputação individual e nenhum controle partidário sobre o processo, candidatos competiriam não apenas com oponentes de outros partidos, mas com os candidatos do seu próprio partido, criando disputas internas no partido.

À análise é acrescida, portanto, a competição intrapartidária. Isto é, além do partido “desaparecer" porque a lista aberta estimularia o individualismo, é feito ausente também como elemento organizador das candidaturas, permitindo que políticos de um mesmo partido disputem os mesmos votos. Esses candidatos, sob uma mesma agremiação, poderiam canibalizar-se nesse sistema em que todo mundo compete entre si ao mesmo tempo (Carey \& Shugart, 1995, p.423), reforçando a deslealdade no interior do partido, o que contribui para seu enfraquecimento.

Sob esta abordagem são feitas as análises e interpretações sobre o caso brasileiro. A adoção da representação proporcional de lista aberta seria responsável, portanto, não apenas pelo distanciamento de partidos enquanto agremiações de caráter societárioideológico orgânico, e consequentemente uma aproximação do modelo em que agremiações são entes funcionais que apenas servem aos interesses políticogovernativos. Adicionalmente, as escolhas institucionais levariam partidos ao extremo do modelo do individualismo: seu papel seria meramente protocolar, esvaziado de ação coletiva e motivações político-ideológicas.

A análise do modelo adotado para o sistema eleitoral revela que dele emanam, de fato, incentivos às ações individualistas dos candidatos e políticos. A lista aberta contribui para que o vínculo estabelecido entre eleito e eleitor seja pessoal. E, desta estrita perspectiva, é coerente afirmar que partidos são preteridos do sistema, bem como da

\footnotetext{
${ }^{1}$ Termo primeiramente cunhado por Mayhew (1974).
} 
análise. Sob esta abordagem, eles desempenham apenas um papel formal, servindo meramente à inscrição das candidaturas.

Essa não é uma análise equivocada da lista aberta quando se concentra apenas nos incentivos que emanam dela. Partidos são omitidos da interpretação porque a engenharia institucional adotada, cristalizada grosso modo na lista aberta, teria os tornado irrelevantes na organização do processo eleitoral que se inicia já no momento pré-eleições. É preciso ressaltar, entretanto, que se por um lado, esse desenho institucional traçado da arena eleitoral confere ampla expressão à individualidade dos candidatos e políticos e - à primeira vista - parcas possibilidades de controle partidário, por outro ele não é o único determinante de incentivos no sistema eleitoral nacional. Ele figura apenas parte do desenho, apenas alguns aspectos dos elementos institucionais vigentes, mas outros elementos coexistem. O equívoco analítico não reside em afirmar que a lista aberta cria tais incentivos, mas em considerar que apenas ela caracteriza todo o desenho institucional.

O cálculo cujo único expoente é a lista aberta peca por não incluir outras variáveis institucionais que alteram os incentivos desse sistema de representação - e é sob esta perspectiva negligente que se assenta a maior parte dos diagnósticos sobre o Brasil (por exemplo, Lamounier, 1992). Não são considerados, sob esta abordagem, múltiplos incentivos que a legislação eleitoral suscita, como as leis que incidem sobre as organizações partidárias e seus limites de atuação, e a dinâmica da competição em si. Sobretudo deixa-se de considerar os incentivos gerados pela magnitude dos distritos eleitorais, particularmente elevada no Brasil, mesmo nos estados menos populosos. É sintomático que a magnitude seja um assunto recorrente nas análises da ciência política (Benoit, 2001; Carey \& Hix, 2011; Chang \& Golden, 2007; Rae, 1995; Shugart, Valdini, \& Suominen, 2005), mas essa relevância não se reflete nos estudos dos incentivos que atuam sobre a arena eleitoral brasileira. 


\section{2 - Incentivos da legislação e os partidos enquanto agentes da decisão}

Um sistema eleitoral não é composto apenas da regra de seleção que determina a maneira pela qual os votos serão traduzidos em cadeiras legislativas. Análises que consideram apenas essa característica desconsideram outros elementos institucionais existentes dos quais emergem, igualmente, incentivos que balizam o comportamento dos atores envolvidos: partidos, candidatos e eleitores. É preciso observar, também, quais são os movimentos ditados pelas instituições no que tange, especificamente, ao papel dos partidos.

Se acrescido o controle partidário conferido pela legislação àquelas análises, o quadro se apresenta de uma forma diferente. De acordo com o artigo 87 do Código Eleitoral $\left(\text { Lei } \mathrm{n}^{\circ} 4.737 / 1965\right)^{2}$ partidos são o único meio de obtenção de cargos públicos elegíveis. Isto é, partidos possuem legalmente o monopólio da representação política porque as candidaturas dependem de vínculo comprovado com essas agremiações (Lavareda, 2009).

A justificativa dos estudos que advogam pela deficiência das lideranças partidárias no processo eleitoral assenta-se sobre a cláusula do candidato nato ${ }^{3}$ somado à lista aberta (Carey \& Shugart, 1995; Samuels, 1997). O artifício do candidato nato garantia a manutenção da candidatura dos incumbentes, ou seja, partidos não tinham permissão para barrar eleitoralmente um deputado que quisesse concorrer à reeleição. Entretanto, sua revogação em $2002^{4}$ torna esse argumento inconsistente ${ }^{5}$. O papel dos partidos

\footnotetext{
${ }^{2}$ Conforme o Código Eleitoral supracitado,
} "Do registro dos candidatos:

Art. 87. Somente podem concorrer às eleições candidatos registrados por partidos.

Parágrafo único. Nenhum registro será admitido fora do período de 6 (seis) meses antes da eleição.

Art. 88. Não é permitido registro de candidato embora para cargos diferentes, por mais de uma circunscrição ou para mais de um cargo na mesma circunscrição.

Parágrafo único. Nas eleições realizadas pelo sistema proporcional o candidato deverá ser filiado ao partido, na circunscrição em que concorrer, pelo tempo que for fixado nos respectivos estatutos."

3 “Art. 8 (..), § $1^{\circ}$ Aos detentores de mandato de Deputado Federal, Estadual ou Distrital, ou de Vereador, e aos que tenham exercido esses cargos em qualquer período da legislatura que estiver em curso, é assegurado o registro de candidatura para o mesmo cargo pelo partido a que estejam filiados." (Lei n ${ }^{\circ}$ 9.504/1997)

4 Ação Direta de Inconstitucionalidade (ADIN) no 2.530-9, segundo a qual "O Tribunal, por maioria, deferiu a medida cautelar para suspender a eficácia do $\S 001^{\circ}$ do artigo $008^{\circ}$ da Lei $n^{\circ} 9.504$, de 30 de setembro de 1997 “. 
enquanto agentes decisórios, compelidos pela legislação, a decidir pela autorização de um candidato ao exercício da representação e do sustento público-eleitoral do partido foi reforçado. Como oportunamente já afirmara, mesmo antes da queda da candidatura nata, o político Claudio Lembo, "só se é candidato quando a oligarquia partidária permite" (1999, p. 77).

Ora, se por um lado, partidos são forçados a assumirem as rédeas decisórias no momento pré-eleitoral pela legislação, é somente perante essa determinação que a eleição se faz possível. A autorização legal confere, assim, ao partido uma oportunidade de desenvolvimento de gerência tática num terreno cujo alicerce era interpretado como o desgoverno partidário habilitado no isolado cenário permissivo da lista aberta.

Esse argumento que toma partidos como a pedra-de-toque das candidaturas é mobilizado por Norris (1993; Norris \& Lovenduski, 1995) na efígie do gatekeeper. São os porteiros partidários que decidem quem poderá integrar a lista de candidatos. Cristalizados nos filiados, ou nos membros do partido, da organização partidária, de várias lideranças ou apenas um líder (variando de partido a partido), o corpo do gatekeeper é o responsável por escolher quem poderá concorrer.

Segundo o argumento (Norris, 1997), cidadãos elegíveis do ponto de vista legal estariam sujeitos às demandas e preferências políticas dos gatekeepers. Junto ao processo de recrutamento, eles seriam moldados pelas implicações do sistema eleitoral num funil de causalidade no qual, em um extremo haveria todas as possibilidades de cidadãos elegíveis e, no outro, a lista de candidatos formatada internamente. Nesse afunilamento, a escolha racional assume que o outcome sempre será guiado por selectores maximizadores. Assim selecionadores procurariam compor listas com forte apelo frente ao eleitorado, com o objetivo de conquistar o maior número de cadeiras quanto que for possível (Norris, 2004).

Norris e Lovenduski (1995) evidenciam que o sistemático enviesamento social que acomete parlamentos é fruto do trabalho deliberado dos gatekeepers. O caso britânico, por exemplo, evidencia que parlamentares eleitos (no geral "middle-aged white men") têm olhar crítico à sub-representação de gênero e raça, e conferem aos selecionadores a

\footnotetext{
${ }^{5}$ Vale ressaltar que o artifício do candidato nato, prescrito pela Lei $n^{\circ}$ 9.504/97, só vigorou nas eleições de 1998 - ver nota 4 acima.
} 
responsabilidade sobre a não inclusão desses setores no corpo parlamentar. Essa responsabilidade não teria sua origem, segundo eles, no preconceito ou num imaginário no qual mulheres e negros seriam menos dotados de capacidades e habilidades políticas, mas na escolha partidária de candidatos com "perfil seguro" do ponto de vista eleitoral, evidenciando que o corpo que seleciona preocupa-se com a formatação da lista sob o prisma maximizador.

Dado que o funil de seleção é delineado pelo sistema político (Norris, 1997) cabe, portanto, questionar como ele age sob o ângulo da lista aberta. O caso finlandês, a exemplo disso, é observado por Helander (1997). O autor argumenta que na Finlândia se soma à lista aberta a possibilidade de candidaturas avulsas ${ }^{6}$, reforçando o caráter individualista do sistema político do país. Nele, partidos não têm prerrogativas para impor obstáculos substanciais às candidaturas, mas, ainda assim, a análise revela que a lista de candidatos é relativamente elitizada, composta majoritariamente pelo "perfil eleitoral seguro" do ponto de vista partidário, à semelhança do caso britânico. Helander aponta que a despeito dos incentivos da lista aberta, há evidências de que o funil de seletores age na escolha de candidatos, optando por aqueles com altas chances de vencer e vetando candidatos pouco competitivos.

Destarte, o controle partidário maximizador sobre a lista de candidatos pode existir mesmo em sistemas cuja ênfase não recai sobre as agremiações partidárias, mas sobre a reputação individual dos candidatos. Convém destacar, entretanto, a reputação dos candidatos se faria necessária na construção das campanhas com vistas à obtenção de votos, mas não no momento pré-eleições. Isso implica que incentivos individualistas nas eleições e a atuação partidária na formação das listas podem coexistir. Na escolha de seus candidatos partidos estariam livres daqueles incentivos individualistas para atuarem como gatekeepers, conforme afirma Norris. A preponderância da reputação individual dos candidatos propalada pela lista aberta não bloqueia a atuação da coordenação partidária no caso finlandês (Helander, 1997). Ora, resguardadas as devidas diferenças, porque haveria de bloquear no caso brasileiro?

Essas indagações são partilhadas por um volume considerável de trabalhos que buscam compreender o papel partidário sobre o recrutamento político e a seleção de candidatos

\footnotetext{
${ }^{6}$ Desde que cumpram a exigência de colher cem assinaturas de cidadãos aptos ao voto.
} 
(cf. Bolognesi, 2013; Braga, 2008; Braga, Veiga, \& Miríade, 2009; Guarnieri, 2004; Marenco \& Serna, 2007; Perissinotto \& Miríade, 2009). Estes, em variados graus, encontram, seja ao apontar especificações estatutárias dos partidos, ou analisar os processos de seleção da máquina organizacional, que as decisões ocorrem no interior das agremiações respeitando as preferências, vontades e demandas do partido em questão. Se, a despeito dos estímulos de centralização nos candidatos providos pela lista aberta, partidos se fazem presentes via determinação legal no processo eleitoral, caberia refletir, então, quais seriam as motivações e os meios de atuação dessas agremiações. 


\section{3 - Incentivos eleitorais: coordenação "estratégica” partidária}

Àquela abordagem que reconhece os partidos enquanto agentes da decisão sobre a representação política avança outra perspectiva que salienta o papel estratégico que tais decisões podem ter. Norris (2004) já salientara essa possibilidade, perante as premissas do neoinstitucionalismo da escolha racional, apontando partidos enquanto atores que buscam a maximização de seus votos e, consequentemente, de cadeiras.

Deveras um partido pode ter um sem número de fundamentos que podem justificar suas escolhas. Norris aponta que estes podem ser fatores ideológicos, ou o mero favorecimento a candidatos próximos a uma facção do partido. A nomeação pode acontecer ainda por proximidades pessoais, papel preponderante frente ao eleitorado, ou habilidades políticas, retóricas, etc. Sejam quais forem essas motivações, entretanto, elas só serão razoáveis de uma perspectiva maximizadora se os candidatos escolhidos tiverem chance de sucesso, isto é, se conseguirem garantir o acesso do partido a cadeiras parlamentares.

Nesse sentido, Cheibub e Sin (2015) apontam para o uso das listas de candidatos enquanto recurso estratégico de partidos. Apontam a importância dos partidos em sistemas de representação proporcional de lista aberta de altas magnitudes, já que eles teriam papel decisivo no equilíbrio de um sistema cuja estabilidade é fluida (p.4). Partidos são responsáveis, segundo os autores, pela continuidade temporal das escolhas eleitorais. Em contrapartida às análises que descartam o papel partidário em sistemas de elevado nível de personalismo, os autores defendem que se houverem meios institucionais para o exercício do controle do partido sobre a arena eleitoral, ele o fará. Se esta possibilidade for real, não resta ao partido a opção de não coordenar uma vez que a abdicação do papel de gerência pode acarretar em custos reais à agremiação.

Cheibub e Sin mostram que agremiações não podem permitir que qualquer candidato endosse sua lista de candidatos porque isso poderia colocar em risco outras candidaturas. Se por um lado a legislação brasileira permite que partidos apresentem um número bastante elevado de candidatos ${ }^{7}$, o número de candidaturas nunca excede

\footnotetext{
${ }^{7}$ A legislação prescreve que partidos ou coligações podem apresentar duas vezes o número de cadeiras quando a magnitude $\mathrm{M}$ do distrito não exceder $\mathrm{M}=20$ e 1,5 vezes o número de cadeiras quando $\mathrm{M}$ for maior ou igual a $\mathrm{M}=20$. No caso das coligações, o número de candidatos lançados por um partido pode
} 
metade do total permitido. Somada a essa evidência, apontam que partidos diferenciam seus candidatos de acordo com as suas chances de sucesso eleitoral. Candidatos podem ser invencíveis, fortes ou fracos na tipologia dos autores. A grande massa deles seria composta pelos candidatos fracos, que agregam votos ao partido, mas não prejudicam os postos "garantidos" dos invencíveis, bem como não põem em perigo as chances de sucesso dos candidatos fortes.

Assim, partidos teriam de promover um cálculo estratégico na definição e no veto das possíveis candidaturas de forma a não ameaçar candidatos bem estabelecidos no partido e conseguir alocar o maior número de candidatos elegíveis quanto o possível. Para tal, precisam considerar que quão maior for o número de candidatos competitivos na lista, maior é a incerteza de um candidato sobre sua vitória. E quão maior for sua incerteza de sucesso, maiores as chances que este possa migrar de partido ou deixar de concorrer, diminuindo assim as possíveis conquistas partidárias.

Sob esta perspectiva, a organização otimizada da lista de candidatos pode conferir aos partidos maior estabilidade em suas relações com candidatos competitivos eleitoralmente e, consequentemente, maior número de cadeiras obtidas em uma eleição. Já aos candidatos, o uso tático da lista pode garantir segurança e alta probabilidade de sucesso eleitoral. Essa otimização dependeria do cálculo estratégico que apenas as lideranças partidárias seriam capazes de elaborar.

O segredo da lista bem elaborada residiria na alocação adequada de candidatos. Se um partido for capaz de contornar a dupla competição, interpartidária e intrapartidária, que candidatos enfrentam em sistemas de representação proporcional de lista aberta, conseguiriam eleger o número máximo possível de candidatos no interior dos distritos, maximizando de fato seus ganhos eleitorais. O caminho que resta é traçar estratégias com capacidade de driblar a competição interna originada pelo sistema eleitoral. Este caminho passa pelo esquivo da sobreposição das candidaturas sob um mesmo eleitorado.

exceder o limite deste partido caso seu parceiro de coligação não preencha toda a lista. Assim, se um partido A e um partido B são coligados num distrito de $\mathrm{M}=8$ e o partido A lançar apenas 10 candidatos, o partido B pode lançar até 22 candidatos (ocupando suas 16 vagas possíveis prescritas pela lei e as vagas não preenchidas pelo partido $\mathrm{A}$ da coligação). 


\section{4 - Incentivos eleitorais: magnitude, distritos e regionalização}

A alocação premeditada de candidatos na lista pelos partidos não seria suficiente para evadir os efeitos da competição intrapartidária. Isso porque candidatos de toda sorte fracos, fortes ou invencíveis (Cheibub \& Sin, 2015) - poderiam disputar votos de um eleitorado coincidente, uma mesma base eleitoral. Isto é, candidatos considerados competitivos no interior de um mesmo partido podem competir pelos votos dos mesmos eleitores. A estratégia da mera designação de um determinado número de candidatos, por si, não logra tais efeitos.

Há várias estratégias que partidos podem adotar para contornar a sobreposição de candidatos sob um mesmo eleitorado. Eles podem lançar candidaturas extraterritoriais, como os puxadores de votos, ou candidatos por categoriais (como sindicalistas, professores, policiais), pinçando um eleitorado específico e disperso. Outra forma possível é recorrer a estratégias de regionalização de candidatos na lista. Shugart et al (2005) destacam a importância de atributos pessoais fixos, como local de nascimento e experiência política prévia $^{8}$, na obtenção de votos em sistemas centralizados nos candidatos, como é o caso da lista aberta. Sobretudo em sistemas de alta magnitude, quando um número elevado de candidatos concorre por um mesmo partido, os atributos fixos ${ }^{9}$ conferem aos candidatos expertise sobre a localidade em questão e ao eleitor, atalhos sobre como escolher o seu candidato.

Além disso, ainda que, diferente de sistemas uninominais - nos quais a representação geográfica é uma matéria institucional -, a representação proporcional não engendre, ao

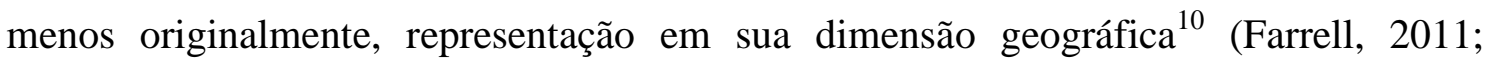
Lijphart, 1977, 1999), Latner e McGann (2005) mostram que esse componente espacial se faz presente. Ao analisar o caso holandês e israelense, os autores assinalam que mesmo com o sistema de representação proporcional nacional ${ }^{11}$ é possível identificar

\footnotetext{
${ }^{8}$ Segundo os autores, o comportamento dos políticos pode ser alterado toda vez que for racional fazê-lo, entretanto, atributos fixos são indissociáveis dos candidatos, figurando bons indicadores frente ao eleitorado (Shugart et al, 2005).

9 Gallagher e Marsh já destacaram a importância das "raízes locais" no que tange a características pessoais dos candidatos (1988, p. 251).

${ }^{10}$ Isso é, inclusive, apontado como uma crítica ao sistema de representação proporcional, como aponta Farrel, 2001.

${ }^{11}$ Sistema em que há apenas um distrito eleitoral nacional, ao invés de múltiplos distritos, como no caso brasileiro.
} 
estratégias de regionalização (Latner \& McGann, 2005). Vale ressaltar que esse sistema eleitoral é o que, em teoria, menos fornece incentivos para estratégias espacializadas. Não obstante, em ambos os casos, partidos teriam regras internas balizadas pelo regionalismo sem, contudo, ter incentivos institucionais formais para tal. Essas regras seriam resultado da motivação dos partidos, cujos objetivos seriam a maximização de seus votos. Essa estratégia de regionalização ocorreria, afirmam, em decorrência da dinâmica da competição eleitoral em si.

Ora, se mesmo em sistemas sem qualquer base para regionalização, como é o caso daqueles em que há apenas um distrito eleitoral nacional, existem estratégias nesse sentido, porque o mesmo não aconteceria em sistemas de múltiplos distritos com altas magnitudes? A distribuição de cadeiras legislativas em distritos sub-nacionais seria responsável por motivar a criação de bases regionais para a representação (Latner \& McGann, 2005, p.712), sendo a hipótese da espacialização nitidamente plausível, inclusive, para esses sistemas ${ }^{12}$. Esse é o exato caso do sistema brasileiro.

O caso brasileiro fornece um cenário análogo aos investigados por Latner e McGann. Ao distrito nacional dos casos israelense e holandês estudados pelos autores pode ser traçado um paralelo aos distritos brasileiros, isto é, suas unidades federativas. Seus distritos têm, majoritariamente ${ }^{13}$, magnitude elevada e, consequentemente considerável extensão territorial e populacional. Ademais, o caso brasileiro de representação proporcional não foi adotado para contemplar clivagens (étnicas, raciais ou de gênero, por exemplo) (Souza, 2001), o que reforça que bases eleitorais de cada distrito não estão necessariamente dispersas ao longo do território. Em outras palavras, a constituição de uma possível base eleitoral não se dá necessariamente com base em características dos eleitores que se distribuem ao longo do país (como raça), mas pode se dar com base em características concentradas, como a localidade.

\footnotetext{
${ }^{12}$ Esse argumento é também apontado por Ames (2003) para o caso brasileiro. Entretanto ele assenta-se sob o pressuposto do distributivismo. Endossado por Pereira e Mueller (2003a, 2003b), a hipótese distributivista como regra do funcionamento do sistema político brasileiro foi rebatida por Figueiredo e Limongi (2002), Mesquita (2008), entre outros.

${ }^{13}$ A magnitude mínima dos distritos brasileiros é $\mathrm{M}=8$, que seguindo os critérios de Carey e Hix (2011) são o limite superior dos distritos de magnitude moderada (que variam entre 3 e 8). A maior parte dos distritos brasileiros tem magnitude superior a 8 , sendo a média $M=19$ e a mediana de $M=10$.
} 
Em consonância, o tamanho dos distritos pode ser um empecilho a muitas candidaturas. É custoso, tanto da perspectiva financeira e temporal, quanto da mobilização do capital humano partidário, fazer campanha em distritos de magnitudes tão elevadas. Esse fator dificulta o cenário não só para partidos, mas também para candidatos. Samuels (2001) apontou que, dentre outros fatores, a estrutura do sistema eleitoral brasileiro causa demasiado aumento no custo das campanhas eleitorais. Nesse sentido, é plausível tanto para candidatos quando para partidos adotar uma abordagem territorial quando da formação de suas estratégias eleitorais. Além disso, como afirmam Latner e McGann (2005):

em termos de competição eleitoral, um partido seria extremamente ingênuo em lançar uma lista de candidatos de uma única região (digamos, a capital). Outros partidos poderiam facilmente se aproveitar disso e usar o regionalismo como um apelo. Além disso, seria bastante útil possuir candidatos locais para fazerem campanhas em regiões diferentes. A regionalização das listas também pode ser vista como um recurso político, o qual os partidos objetivam distribuir de forma a maximizar seus votos totais, bem como distribuem outros recursos ao longo da campanha, como dinheiro (p.712) ${ }^{14}$.

Assim, a motivação de regionalizar a lista de candidatos como um recurso estratégico de campanha se dá pela dinâmica da competição - se um partido não se aproveitar disso, outro o fará. E também por uma lógica partidária. Isso é, ao fazê-lo, ao menos intrapartidariamente, esquiva-se da competição (Latner \& McGann, 2005, p.713), que é resolvida pela alocação dos candidatos na lista de acordo com a divisão no interior dos distritos.

Dessa perspectiva, cada um dos múltiplos distritos brasileiros se assemelharia aos distritos nacionais analisados por Latner e McGann. Seria no interior de cada um deles que partidos lançariam mão de suas estratégias, compondo suas listas de forma a evitar que candidatos de uma mesma localidade sejam lançados num mesmo pleito. Sem a

\footnotetext{
14 Tradução própria.
} 
disputa no interior dos partidos, a incerteza intrapartidária eleitoral minguaria sensivelmente (Cheibub \& Sin, 2015, p.7).

Essa regionalização das campanhas e, consequentemente, dos votos não depende de relações clientelistas entre políticos e eleitores. Ainda que parte da literatura já tenha apontado para a baixa probabilidade de que essa estratégia distributivista seja a regra do funcionamento do sistema político brasileiro (Carvalho, 2003; Figueiredo \& Limongi, 2002; Mesquita et al., 2014), não se pretende aqui negar que ela possa existir no Brasil, ou em outros sistemas de lista aberta. O ponto central, por outro lado, é que mesmo sem o constrangimento institucional formal, partidos podem fazer uso da dinâmica regional dos distritos para tecer suas estratégias e aumentar suas chances de sucesso eleitoral.

Jankowsky (2016) mostra a efetividade da adoção de estratégias geográficas para o caso alemão de lista aberta. O autor reforça que o eleitorado não só "procura os locais" como já afirmaram Shugart et al (2005), mas vota neles preponderantemente. Conforme o autor, o localness de um candidato influi diretamente sobre as suas chances de sucesso eleitoral já que essa característica seria responsável por oferecer atalhos informacionais aos eleitores ${ }^{15}$, além de uma proximidade maior com o eleitorado e os problemas locais. Marsh (1987, p. 66) argumenta, antes, que a experiência política local contribui para canalizar demandas locais. Esse ponto é endossado por Tavits (2010), ao analisar o caso estoniano, que mostrar a predileção pelo candidato local que nasceu ou possui cargos políticos na região em questão, especialmente nos casos em que há muitos candidatos de um mesmo partido (e, portanto, possuem opiniões ideológicas semelhantes, de difícil diferenciação frente ao eleitor).

Essa argumentação ganha corpo nos estudos da geografia eleitoral. Seus autores mostram como a regionalização influencia a dinâmica do voto e lançam luz sobre como partidos podem fazer uso de uma estrutura espacial onde, inevitavelmente, estão assentadas todas as faces do processo político-eleitoral: a formação das listas, as estratégias partidárias, as campanhas, o voto e também a governança, em si.

\footnotetext{
${ }^{15}$ Esses atalhos seriam necessários porque, como já destacaram Lau e Redlawsk (2006), quão maior o número de candidatos, maior a necessidade de atalhos informacionais aos eleitores.
} 


\subsection{1 - A geografia eleitoral}

Se de um lado parte da Ciência Política aponta para as motivações e possibilidades de gerência estratégica que partidos podem desenvolver para maximizar seus votos, de outro a geografia eleitoral sofistica esse argumento ao acrescentá-lo ao debate da dimensão contextual que articula processos de interação que se dão num plano estrutural intrínseco ao mundo social. Esse plano, especificamente no caso da representação proporcional de distritos de alta magnitude, articula processos engendrados tanto em escala macro quanto micro. Em outras palavras, inclui a dimensão nacional, na qual estão inseridos o sistema eleitoral e os partidos, bem como suas decisões; e também a dimensão micro, na qual a dinâmica local caracteristicamente se reifica.

Sob esta ótica, candidatos não agiriam à revelia das decisões das lideranças de seus partidos, nem se descolariam do label que o partido lhes fornece, como advogam Cox e McCubbins (1993). Mas atuaria sobre esses candidatos, sobre partidos e eleitores a estrutura regional-distrital instituída no contexto em que se dão as relações entre os atores e os processos de interação de nível local e nacional. De maneira semelhante, Agnew (1987) argumenta que o comportamento político é necessariamente geográfico e sua compreensão deve, portanto, abranger uma perspectiva baseada em um processo de múltiplas dimensões.

Assim, candidaturas estariam subjugadas à dinâmica política, mas também à espacial. Essa dinâmica espacial, característica do environment, como destacam Huckfeldt e Sprague (1987), teria papel crucial ao expor atores a contextos e vieses específicos que variam conforme o local. Essa exposição seria o reflexo da estrutura sociogeográfica, que dita o ritmo e o fluxo de informações que chega aos eleitores, fluxo este que também influencia como um "viés local", inevitavelmente, os partidos e suas candidaturas - o comportamento político como um todo.

Dessa perspectiva, as esferas social e espacial formariam o contexto do dia-a-dia, da vizinhança dos atores. Este ponto já fora apontado originalmente por Key (1949), o qual, em estudo sobre o eleitorado do sul dos Estados Unidos, mostrou que as decisões dos eleitores se baseavam no que chamou de "friends-and-neighbors effect", o efeito da vizinhança. A opinião política dos eleitores seria influenciada pelo seu local de origem, 
ou de moradia. Eleitores teriam preferência por candidatos locais uma vez que se baseiam no cálculo da promoção do interesse local. O que justificaria essa preferência "localista" não seriam políticas de caráter distributivista, mas a valorização de sua região na arena legislativa e a informação que chega até eles, pelo fluxo informacional característico ao espaço e influencia a sua tomada de decisão. Em consonância, McPhee (1972) reforça que preferências políticas são configuradas por múltiplas interações sociais e que estas estão entrelaçadas com as estruturas locais.

Por conseguinte, atores políticos não podem ser considerados independentes do meio no qual estão inseridos. Esse meio seria o responsável, via localismo, pela provisão do núcleo eleitoral que concederia votos ao candidato local, ou de cidades contíguas (Key, 1949, p. 132). Nota-se que a influência do componente geográfico aparece aqui de forma um tanto mais sofisticada do que no argumento do paroquialismo (por exemplo, Ames, 2003).

O localismo ocasionado pelo environment que baliza o fluxo de informações é articulado, nesse enfoque, no conceito do contexto. O contexto seria responsável pela propagação das informações sobre os candidatos, alterando o que chega ao eleitor e influenciando a sua opinião e o seu voto. A dimensão do contexto é explorada como um “escopo geográfico de influências específicas, os limites em termos de razões práticas, e os significados distintos de discursos associados ao agente humano que convive com (...) influências" (Agnew, 1996, p. 130). Assim, a articulação promovida pela geografia eleitoral se dá entre um plano macro, estrutural, e um plano micro, mais contido à agência promovida na esfera local. Nas palavras do autor,

contexto se refere ao afunilamento hierárquico de estímulos através de escalas ou níveis geográficos para produzir efeitos na política e comportamento político. Estes efeitos podem ser pensados como uma junção em lugares onde processos de estruturação social micro (localizado) e macro (amplo alcance) são conjuntamente mediados. (...) [Ele] canaliza o fluxo de 
interesses, influencia e identifica qual atividade política emana. (Agnew, 1996, p. 132-133) ${ }^{16}$.

Preferências e comportamentos seriam expressões micro-sociológicas do contexto do espaço. Em outras palavras, o contexto seria a influência que atua na vida dos atores políticos diariamente. Isso independe da arena política eleitoral ou de constrangimentos institucionais e envolve as informações que chegam e são trocadas entre os moradores das cidades vizinhas, por exemplo. Ou, conforme Huckfeldt e Sprague (1987), o contexto é definido geográfica e socialmente e as informações que eleitores consomem são providas por ele, de forma que suas decisões são por ele balizadas.

Esse argumento é reforçado por Burbank (1997, p. 114), que afirma que as informações obtidas pelos eleitores vêm de seus ambientes sociais. Decorre disso que as informações políticas com as quais eleitores se deparam são enviesadas de acordo com a composição do arranjo local e social do eleitor. Da perspectiva do fluxo de informações, efeitos contextuais são resultados da estruturação da informação política pelo environment de maneira que elas atingem diretamente como eleitores pensam e agem politicamente.

O fluxo informacional constrangido pelo contexto impacta eleitores de maneira diferente, variando de acordo com o contexto, já que

(i)nformação eleitoral relevante flui através de redes sociais e estimula respostas na forma de decisões partidárias: se a informação atingindo um indivíduo através de suas conversas predominantemente favorece um partido, então este indivíduo é mais propenso a votar por (ele), a despeito de suas predisposições anteriores, do que se a informação fosse menos enviesada em outra determinada direção (Pattie \& Johnston, 2000, p. 42) ${ }^{17} 18$.

\footnotetext{
${ }^{16}$ Tradução própria.

${ }^{17}$ Cabe ressaltar aqui que os autores analisam as eleições parlamentares do Reino Unido. Neste país eleições legislativas são organizadas em torno dos três partidos nacionais, Liberal, Trabalhista e Conservador. Neste sistema, só há um candidato lançado por cada partido em cada uma das constituencies eleitorais, cuja magnitude é igual a um. O favorecimento de "um partido", como citam os autores, se deve a tal característica que, para os fins do argumento desenvolvido neste trabalho, se faz análoga a candidatos num sistema de multimember district como o brasileiro.

18 Tradução Própria.
} 
Dessa forma, a depender de como as informações chegam e, sobretudo, de quais informações chegam, a decisão eleitoral pode ser criada e alterada. Se as informações são constrangidas pelo contexto, então se deduz que a opinião do eleitor e seu voto também o são. Isso porque, nas palavras de Agnew,

(e)sta perspectiva assume, portanto, que o comportamento político é inevitavelmente estruturado por uma mudança de configuração das influências sociais e geográficas como as conexões globais-locais mudam ao longo do tempo (1996, p. $133)^{19}$.

Isto é, estruturas sociais e padrões de interação social gerados pelo espaço engendram comportamentos políticos, como o voto e as decisões político-partidárias (Dyck, Gaines, \& Shaw, 2009).

A importância das estruturas locais sob esta perspectiva tem seu lócus sob um conceito que é lugar comum na Ciência Política. Elas se situam no interior das constituencies, cujo processo de formação interessa também a esta abordagem (Johnston, 2001, p.4374), bem como a geografia do padrão de votação que delas resulta. Se sob a abordagem distributivista essas mesmas constituencies estavam relacionadas com a interação de cunho essencialmente paroquialista entre políticos e eleitores, nesta o argumento é refinado e seria, por outro lado, uma consequência da dimensão geoespacial que cria e retroalimenta a dimensão social, entrelaçando-se mutuamente.

Como consequência, não só a opinião eleitoral, mas também decisões e estratégias de candidatos e partidos são impactadas pelo contexto socioespacial (Potter \& Olivella, 2015). Nesta argumentação, múltiplos são os fatores de interação que justificam os resultados eleitorais, sendo as iniciativas clientelistas apenas uma deles.

Estes argumentos são aplicados ao caso brasileiro por Terron (2009). Ao tratar das eleições presidenciais, a autora argumenta que os “[c]ondicionantes políticos, econômicos e sociais interagem em diversas escalas geográficas e podem determinar diferenças significativas no comportamento eleitoral” (2009, p. 12). Remontando Key (1949), afirma que um candidato dependeria do efeito da vizinhança para firmar sua base eleitoral. Isso porque para o eleitor o que influenciaria suas escolhas políticas seria

\footnotetext{
${ }^{19}$ Tradução Própria.
} 
o contexto mais próximo do seu cotidiano, o que independe de candidatos e partidos políticos específicos, mas estaria envolvida na troca de informações.

Haveria também, para Terron, uma relação entre as preferências políticas e o contexto social dos eleitores, de maneira que seria fundamental dar maior atenção às interações entre os cidadãos que moram nas mesmas áreas e nas trocas de informações exercidas entre eles. Essas trocas se concretizariam no acesso aos jornais, redes de televisão e rádio locais que abrangem as regiões em que eleitores residem, bem como o uso que fazem dos transportes disponíveis entre cidades, tendo em vista a proximidade e a acessibilidade. Nesse contexto, o eleitorado não pode ser considerado independente do meio no qual vive e seria responsável, via localismo, pela provisão do núcleo eleitoral que concederia os votos ao candidato local, ou o candidato das cidades contíguas (Terron, 2009, p. 132).

Segundo a autora, a incorporação do espaço geográfico e suas relações sociais e econômicas nos estudos sobre o comportamento político-eleitoral e a concentração de votos pode "revelar processos subjacentes que permanece[riam] 'invisíveis"” (p.13), e contribuir para não subestimar ou sobrestimar efeitos daqueles que podem ser também importantes determinantes do comportamento político e sua expressão, concretizada no voto.

\subsection{2 - Estratégias partidárias sob a perspectiva da geografia eleitoral}

Se aceita a premissa de que os fluxos de informações são ocasionados pelo contexto socioespacial e estes, em consequência, modelam o comportamento dos eleitores, caberia aos partidos, enquanto atores organizadores do processo eleitoral e cujo objetivo é maximização de seus votos, enfrentar essa dinâmica.

A partir dessa apropriação, partidos poderiam formar suas estratégias a fim de contornar os efeitos perversos - pelo menos no que tange ao ponto de vista da própria agremiação - instaurados pelo sistema eleitoral e pela dinâmica própria da competição, como é caso da competição interna que candidatos de um mesmo partido enfrentam. Livres desses efeitos, partidos poderiam lançar listas otimizadas espacialmente, conferindo mais certeza ao resultado eleitoral esperado. 
Além disso, o uso de redes pré-estabelecidas de fluxo de informações é notadamente profícuo a partidos e candidatos que, ao se apropriar delas, empreenderiam menos esforços de recursos humanos, financeiros e tempo de campanha porque oportunamente seriam beneficiados pela estrutura geoespacial da constituency em questão.

Sob esse prisma interpretativo os sub-distritos informais, apontados por Ames (2003), estão presentes. Mas essas constituencies, resultantes de relações de caráter clientelista, são, na verdade, a expressão reverberada de uma estrutura de relações estabelecidas pelo desenho geográfico e as condições socioeconômicas que o permeia; o resultante da função que relaciona espaço, contexto e política. Consequentemente, a constituency em questão se aproxima mais de um modelo carregado de um sentido territorial-distrital do que a do sentido paroquialista ${ }^{20}$ que Ames confere ao caso brasileiro.

Ademais, ainda que no caso norte-americano e europeu o argumento esteja bastante ligado à fidelização de um eleitorado concentrado geograficamente, ele, na verdade, não se faz necessário. Isso porque não toca necessariamente em questões de fidelidade partidária - característica ausente no caso brasileiro -, mas em questões ligadas à localidade e à proximidade. Em outras palavras, a conexão estabelecida entre candidato e eleitor não se relaciona com questões de identificação propriamente ideológica, mas com a predileção objetiva por um candidato com o qual o eleitor tem algum tipo de contato, mesmo que seja apenas pelas páginas de um jornal local, ou uma conversa com o seu colega de trabalho.

Em suma, a escolha dos eleitores é pautada com base nas informações que eles recebem e estas são enviesadas pelo fluxo de informações que resulta do contexto socioespacial. Nessa dinâmica estão envolvidos eleitores, candidatos e partidos políticos. De um ponto de vista prático, partidos devem se apropriar da estrutura dos sub-distritos, as constituencies, e formular estratégias com bases no que elas favorecem: que eleitores escolham aqueles candidatos com que eles já têm contato mais próximo.

\footnotetext{
${ }^{20}$ Ames (2003) argumenta que a formação de constituencies se daria com base na fidelização clientelista de um eleitorado geograficamente localizado. Isto é, distritos informais seriam constituídos baseados no beneficiamento via políticas paroquialistas a um determinado eleitorado espacialmente localizado, independendo de questões geográficas-espaciais.
} 


\section{5 - Considerações Parciais}

O sistema eleitoral e a dinâmica da competição eleitoral levantam dois problemas aos atores políticos: competição entre diferentes partidos, e a competição entre candidatos de um mesmo partido. Quanto ao primeiro problema, cabe aos eleitores, com base nas informações que chegam a eles, resolver. Já o segundo, é essencialmente partidário. Cabe aos partidos otimizar o seu desempenho na competição e resolver este problema, ou permanecer alheio e arcar com as consequências causadas por problemas de erros estratégicos.

Por um lado, pode-se acreditar que eles o coordenarão porque, como ressaltou Norris (1993), eles são os gatekeepers do processo pré-eleitoral. Eles têm prerrogativas previstas pela legislação e estrutura interna própria para tal. Enquanto porteiros do processo, partidos podem escolher quem serão seus candidatos e, assim, podem barrar candidaturas que disputam entre si bases eleitorais semelhantes e promover candidaturas que não sejam mutuamente conflitantes. Por outro, pode-se acreditar que eles resolverão porque, enquanto agentes racionais maximizadores de seu interesse, como dita o paradigma neoinstitucionalista, é mais adequado, do ponto de vista estratégico, coordenar o processo e tentar evitar a canibalização das suas candidaturas. Desse ponto de vista, partidos que conseguirem organizar suas listas adequadamente teoricamente terão vantagem eleitoral perante aqueles que não o fazem.

Assim, na direção que apontam Cheibub e Sin (2015), essa decisão passaria, obrigatoriamente pela promoção de um cálculo estratégico na formação de suas listas eleitorais. Essas estratégias seriam reveladas pelo "baixo" número de candidatos na lista, e pela alocação destes enquanto uma tipologia de candidatos mais fortes e mais fracos. Mas essa mera alocação não resolve, por completo, o problema da competição intrapartidária. Mesmo sob este ângulo, candidatos competitivos podem disputar bases eleitorais coincidentes.

Dada a sugestão ditada pela abordagem da geografia eleitoral, a hipótese que se delineia é que partidos fazem uso da dinâmica contextual intrínseca ao espaço sob a qual se assentam eleitores, candidatos e partidos para elaborar estratégias de alocação mais eficientes e otimizadas. Nesse ínterim, partidos enquanto gatekeepers racionaismaximizadores elaborariam suas listas de candidatos não apenas estimando o perfil 
competitivo de seus candidatos, mas alocando-os de forma que eles não se canibalizem, garantindo maior certeza ao processo, deixando o resultado eleitoral sujeito não mais a uma dupla competição (no interior e fora dos partidos, como apontam Cheibub e Sin, 2015), mas apenas a uma delas, que só é resolvida pela escolha do eleitor. 


\section{CAPÍTULO 2 - A LISTA DE CANDIDATOS}

O presente capítulo explora a literatura sobre formação de listas de candidatos. Busca-se observar os movimentos traçados pela ciência política sobre este tema e compreender seus avanços, bem como evidenciar suas limitações. A abordagem majoritariamente utilizada por essas análises incide sobre alcance empírico-analítico do que se sabe da decisão partidária da formação da lista de candidatos.

Sabe-se que são as lideranças partidárias que escolhem seus candidatos ao formar as listas de candidatos. Apesar disso, pouco se sabe sobre quais são suas estratégias, como elas se desenvolvem e são postas em prática. Tais lacunas neste campo relativamente pouco explorado na ciência política devem-se tanto a sua recente emergência, quanto a dificuldade de observar e compreender como se dão as escolhas no interior do "jardim secreto" dos partidos.

Dois dos elementos deste processo de formação são o recrutamento político e a seleção de candidatos. Por vezes, as pesquisas tratam ambos separadamente, mas aqui, a exemplo de outros autores, serão expostos juntos porque se admite que são imbricados entre si. É preciso ressaltar, ainda, que uma vez que a finalidade do recrutamento político serve ao lançamento de candidaturas, parece leviano afirmar que partidos não levam em conta aspectos institucionais como as regras eleitorais, deixando essa preocupação para um processo posterior, como a seleção de candidatos. De forma contrária, parece razoável afirmar que as escolhas de caráter sociopolítico feitas no recrutamento são voltadas para o momento da seleção, ou seja, na formação das listas de candidatos. Dessa forma, será dada atenção aos dois processos conjuntamente.

Como será mostrado, os estudos sobre recrutamento aproximam-se do campo da sociologia política, já que carregam uma tradição de análise do perfil social, a educação, gênero, trajetória pública e política, bem como assuntos sobre a profissionalização da política. Tradição esta cujas origens residem no campo normativo estabelecido pelo paradigma behaviorista. Por outro lado, a seleção de candidatos, o processo por meio do qual os candidatos são escolhidos para compor a lista partidária nas eleições, bebe da fonte de premissas normativas do paradigma neoinstitucionalista. Assim, o processo deve respeitar tanto regras eleitorais (como as regras que limitam quem pode ser 
candidato) e regras internas dos próprios partidos em questão, como também fatores informais e contextuais, como aqueles característicos dos indivíduos e do meio no qual eles estão inseridos. A importância desta sugestão do "meio" fora ressaltada pela geografia eleitoral (ver capítulo 1), entretanto fatores contextuais originados pelas características geoespaciais são apenas lateralmente apontados pela Ciência Política.

Nas páginas que seguem, o intuito é oferecer uma sistematização teórica sobre o que foi produzido sobre o recrutamento e a seleção de candidatos que compõem as listas partidárias. Um primeiro esforço se concentrará em discutir a literatura internacional mais relevante sobre o tema, bem como seus problemas e abordagens. Posteriormente, a discussão se volta para análises sobre o Brasil, que são ainda mais recentes e incipientes quando confrontadas com a literatura internacional. Como consequência, esses estudos pouco avançam sobre o que está por trás das escolhas dos partidos, principalmente no que tange aos aspectos ressaltados pela geografia eleitoral, como fatores regionais e geoespaciais, ainda que alguns autores reconheçam a relevância destes elementos. 


\section{1 - O debate internacional sobre a seleção de candidatos e recrutamento}

A importância da seleção de candidatos e a evidência da distribuição de poder dentro dos partidos fora ressaltada, pela primeira vez, em meados da década de 1940. Schattshneider (1942, p. 101) argumentou que "the nominating process has become the crucial process of the party. He who can make the nominations is the owner of the party". É na designação de candidaturas que começa a atividade política. Ter o poder de decidir o ingresso na lista de candidatos define não só quem fará parte da elite política como formata também uma agenda de atuação qualitativa dos partidos, suas escolhas por políticas (Gallagher \& Marsh, 1988) e lança luz sobre a reputação destas agremiações (Cox \& McCubbins, 1993).

A definição da elite política estava posta no cerne dos estudos de seleção de candidatos e o recrutamento político. Inserida no paradigma behaviorista dos anos 1960-1970, a literatura apontava para a baixa relevância do aspecto institucional do processo, cristalizado na seleção de candidatos. Essa etapa pré-eleitoral, enquanto variável independente das análises da ciência política, seria responsável por apontar apenas descrições de parca relevância teórica. A análise dos aspectos institucionais deveria ficar no plano desfocado de um cenário no qual os aspectos "microteóricos" é que seriam capazes de revelar as motivações partidárias quando da formação de seu corpo de candidatos.

A "microteoria" estaria por trás das motivações porque, conforme a abordagem, as instituições seriam elas mesmas frutos das ações dos indivíduos (Homans, 1988). Assim, o sistema de seleção teria sido pensado, desenhado e adotado pela elite política para servir aos seus propósitos, com motivações políticas ${ }^{21}$ (Czudnowski, 1970). Nesse sentido, o estudo do recrutamento é que conseguiria desvendar os elementos diferenciais dos que teriam chance de ingresso político - e, portanto, de elaboração do sistema político e de políticas públicas - e o restante da população. A seleção dos candidatos seria o passo seguinte, um "mero" aspecto institucional de um complexo processo iniciado no recrutamento (Czudnowski, 1975).

\footnotetext{
${ }^{21}$ Nas palavras do autor, "(s)election systems serve political purposes; they are adopted for political purposes and can be changed for political purposes" (Czudnowski, 1970, p. 228).
} 
A tarefa que restou aos analistas foi, portanto, identificar e explorar o diferencial dos candidatos em seus aspectos micro, relegando ao segundo plano a análise macro dos aspectos institucionais. Essa perspectiva preocupou-se em destacar as características sociopsicológicas dos indivíduos recrutados, bem como aspectos econômicos e de sua politização. Assim, fatores como a incumbência, a proximidade com grupos de interesse, a participação no interior da vida do partido, a pertença à estrutura organizacional (Ranney, 1981), sua influência e conexão local (Key, 1949) foram evidenciados como importantes coeficientes na formação da elite política.

Com o início dos anos 1980 e a virada neoinstitucionalista, a análise micro deu lugar a análise macro. As instituições voltaram ao protagonismo analítico, se diferenciando do institucionalismo dos anos 1940, de enfoque detalhista e essencialmente normativo (Peres, 2008) que, carregado de análise de regras internas e estruturas administrativas, pouco dava conta de explicar fenômenos políticos (Steinmo, Thelen, \& Longstreth, 1992). O enfoque analítico passou a ser a maneira pela qual as instituições moldam e estruturam a política, além de buscar compreender como as instituições se desenvolvem e influenciam outcomes. O cerne normativo de que "instituições importam" (North, 1990) não pretendia ignorar avanços anteriores, descartando outras forças da sociedade, mas apontar que são as instituições que estruturam e dão corpo a essas forças, influenciando diretamente seus resultados.

O reflexo dessa guinada neoinstitucional foi notório. A seleção de candidatos, o "jardim secreto da política" 22 , passou a figurar entre as análises, da mesma forma que estudos sobre o recrutamento. Mas a ampla possibilidade de elegibilidade teria evidenciado que é na seleção de candidatos que partidos conseguem influenciar toda uma cadeia de política que se segue, desde a qualidade dos candidatos, a qualidade dos governantes e os outcomes de policy (Gallagher \& Marsh, 1988). Apesar da aparência de tarefa administrativa, procedimental, seria a seleção de candidatos que permitiria partidos moldar sua imagem política, e as policies que emanam do seu corpo político. Permitiria ainda evidenciar quão democráticos são partidos nas condutas dos assuntos internos ${ }^{23}$,

\footnotetext{
22 Anthony Howard apud Gallagher \& Marsh, 1988.

${ }^{23}$ Esse ponto é mais tarde explorado por Freidenberg (2003), que relaciona a democracia interna dos partidos com o grau de institucionalização do partido. A seleção de candidatos seria um indicador de mensuração do nível de democracia interna dos partidos, porque afeta a distribuição de poder no interior das organizações.
} 
constatação esta que trouxe à tona uma maior atenção à relação entre sistema político e a natureza dos partidos internamente.

Dessa perspectiva, ainda que o recrutamento e a seleção sejam regulados pelas leis eleitorais, a batuta legal incidiria mais diretamente sobre o recrutamento. Ele seria regulado por aspectos do sistema político, legais e eleitorais, bem como pelos quadros partidários e, destarte, mais "estático", tornando sua observação mais plausível. Nesse aspecto, Norris (1997) aponta que vários elementos podem influenciar as escolhas dos partidos, como a representação das mulheres, o viés profissional e socioeconômico, e a institucionalização da classe política. A seleção de candidatos, por outro lado, seria o espaço institucional que partidos têm para tratar de seus assuntos, tomar suas decisões de portas fechadas. Nele são considerados diferentes aspectos institucionais, como sistemas políticos, a formatação da lista (aberta, fechada) e as demandas dos partidos. O momento da seleção seria um espaço essencialmente partidário, onde só o próprio partido decide.

Inversamente às análises behavioristas, a opção neoinstitucionalista foi, portanto, investigar ambos os fenômenos. Um imbricado no outro, sem elencar a importância de um em detrimento do outro. Nesse caminho, Gallagher e Marsh (1988) analisam a centralização da seleção, quão extensiva é a participação dos filiados e quais são as qualidades necessárias do ponto de vista individual para ser recrutado e selecionado. Os autores consideram características distintivas do sistema político, como estrutura federativa ou unitária; do sistema eleitoral, como a magnitude dos distritos e a legislação eleitoral; como a natureza dos partidos (no clássico eixo esquerda-direta); e também fatores mais voltados aos indivíduos, como cultura política.

Outra dimensão analítica que emerge é sobre a influência da estrutura dos partidos e como os órgãos partidários incidem sobre as decisões. Ora, ao mesmo tempo em que antes a atenção voltava-se para a formação das elites, nunca como ou quem escolhe esteve no fronte. Conforme Gallagher e Marsh (1988), é notável a importância dos órgãos locais (de nível mais baixo) na escolha, ainda que o órgão nacional também seja essencial. No entanto, a maneira que escolhem depende do sistema eleitoral em questão, e partidos atuariam de modo a balancear interesses e incentivos no background, ou seja, numa arena interna, exclusivamente partidária. 
O equilíbrio de interesses e incentivos nada mais seria do que partidos se sobressaindo como agentes de controle no processo de formação das listas. Nesse sentido, partidos seriam os gatekeepers da seleção e recrutamento (Norris, 1993, 1997), como fora tratado no capítulo anterior. Eles têm prerrogativas para escolher e barrar (pré)candidatos (elegíveis) de acordo com seus interesses. Nesse processo, eles são responsáveis por favorecer e restringir a lista que será ofertada aos eleitores considerando, para tal, critérios legais (elegibilidade), critérios partidários (tempo de filiação, contribuição partidária, entre outros) e sociais (disponibilidade de interessados). Além, é claro, dos seus próprios interesses de maximização, manifestos na forma de estratégias na formação das listas.

A reflexão empírica disso se concretiza na análise das decisões internas dos partidos. Conforme Norris (1993), essas decisões podem ser mais institucionalizadas - quando são regidas por regras e estatutos - ou mais informais. Da mesma forma, podem ser mais centralizadas em órgãos nacionais/regionais, ou menos, quando as decisões são mais locais. Norris considera ainda a oferta de candidatos que desejam concorrer e a demanda dos gatekeepers, que expressam suas preferências na seleção de acordo com suas estratégias e necessidades políticas. O resultado de tudo isso é a lista de candidatos oferecida ao eleitorado.

Ao articular argumentos institucionais, como quando observa características organizacionais e legais dos partidos e quando aponta para a possível dimensão da estratégia na formação da lista, e sociopolíticos, como quando analisa o perfil e a carreira política dos (pré)candidatos, a autora ressalta a importância dos fatores institucionais à análise behaviorista, que não deve deixar de ser considerada. O processo de seleção tangeria a aspectos institucionais adicionais ao recrutamento. Essas contribuições de Norris decerto foram responsáveis por inaugurar uma agenda de pesquisa, cujas análises balizam avanços conforme a sugestão da autora, direta ou indiretamente. Uma série de trabalhos surgiram desde então (Bolognesi, 2013; Braga, 2008b; Braga, Veiga, \& Miríade, 2009; Marenco \& Serna, 2007; entre outros).

Hazan e Rahat (2010) podem ser apontados como o ápice desse desenvolvimento. Responsáveis por elaborar uma metodologia de análise que incide sobre quase todos os estudos de seleção de candidatos, os autores tocam lateralmente em Norris quando assumem a necessidade de optar pelo path institucional também para compreender o fenômeno do recrutamento político. A compreensão dos partidos e do processo político 
deveria passar pela compreensão do funcionamento dos processos de seleção e nas escolhas do recrutamento político. O método desenvolvido privilegia quatro diferentes dimensões, que são um roteiro para a análise da seleção de candidatos. São elas:

\section{Candidatura}

Dimensão que põe em questão quem pode ser candidato, quem é elegível. Pode ser pensada como um continuum, no qual no polo mais inclusivo, todos os eleitores podem ser candidatos. Já no polo oposto, o polo exclusivo, há uma série de restrições às candidaturas. Ela teria como objetivo compreender quais são os filtros partidários para as candidaturas.

\section{Selectorado}

É o corpo que seleciona candidatos, os "selecionadores": um ator intermediário no processo do recrutamento (Best e Cotta, 2000, p.11). Mais uma vez, em um dos seus extremos há um só líder de partido que toma as decisões, e no outro, há um corpo partidário. Essa dimensão é classificada de acordo com a sua inclusividade (Hazan, 2002): quão maior a participação (dos filiados e/ou membros dos partidos) nas decisões, mais inclusivo é o processo. É o selectorado que determina aqueles que são hábeis e elegíveis do ponto de vista do partido para o eleitorado (Norris \& Lovenduski, 2010, p. $135)$.

\section{Descentralização}

É o lócus da escolha. Um partido é centralizado quando o seu selectorado é exclusivamente nacional, ou seja, pertence aos diretórios nacionais. Já quando os candidatos são escolhidos por selecionadores locais, o processo é descentralizado.

\section{Votação versus indicação}

No sistema de indicação, os candidatos são escolhidos e nenhum outro órgão do partido precisa aprovar tais escolhas. Já no sistema de votação, são os votos que determinam a formação da lista, bem como o posicionamento dos candidatos nela.

A análise dessas quatro dimensões teria lançado luz sobre como funciona o processo da seleção dos candidatos no interior de um partido. Decerto a decisão sobre os métodos de 
escolha dos partidos acontece numa arena regulada pelos próprios partidos ${ }^{24}$ e que, apesar de ser decisão única desses atores, pode ser influenciada por diversos fatores (como grupos de pressão, etc.).

A decisão partidária sobre os métodos de seleção, é preciso ressaltar, torna o processo de formação de lista, por um lado, muito volátil entre diferentes partidos. Por outro, ele reflete estratégias e a dinâmica da política partidária (Norris e Lovenduski, 2010). Mas, alterações em seu processo acarretam em mudanças como um todo nessas organizações, já que não se trata apenas da oferta de candidaturas aos eleitores, mas também da composição dos partidos no interior dos governos. Assim, a seleção de candidatos separada da análise do recrutamento - deve ser tratada como um processo que tanto reflete como afeta a política dos partidos.

Um dos pontos centrais dessa discussão é onde ela toca o trabalho de Norris. Do ponto de vista do método proposto, os trabalhos se revelam dissonantes: Norris aponta pela análise dos perfis selecionados, enquanto Hazan e Rahat analisam como a escolha se dá nos partidos. Entretanto, quando Hazan e Rahat exploram o papel partidário no processo, eles se aproximam de Norris. O partido enquanto gatekeeper de Norris se encontra com o selectorado de Hazan e Rahat. A diferença dos termos é mais operacional que teórica quando se assume que, seja o nome que for, a decisão sobre a composição da lista é do partido. Livre de influências ou viés, é a agremiação corporificada em um líder, em lideranças, ou em todos os membros do partido - que bate o martelo, que permite ou não que um nome entre na sua lista. É na formação da lista que se limita o escopo da representação, e quem o faz são os partidos (Rahat, 2007).

Se por um lado as características institucionais e as características dos indivíduos são essenciais para a compreensão do processo de seleção e recrutamento, de outro, análises que observam apenas esses fatores falham ao tentar chegar a conclusões definitivas sobre a formação das listas nos partidos. Esses avanços permitem a descrição e análise dos partidos no que tange àquelas características, mas são incapazes de fornecer explicações abrangentes sobre o processo e sobre as escolhas partidárias. Reconhecer

\footnotetext{
${ }^{24}$ No Brasil, por exemplo, partidos devem publicitar como vai ser o processo de escolha das candidaturas, mas é preciso ressaltar que parte relevante desse processo é dada por meio de decisões informais dos partidos.
} 
este problema foi o ponto de partida de Siavelis e Morgenstern (2008), que criticam a "escolha" institucional de observar fenômenos macro-macro (como a legislação e o sistema eleitoral), mas não macro-micro, como os estatutos dos partidos e outras instituições informais.

A solução residiria na inclusão de variáveis contextuais ${ }^{25}$ e informais. Só considerando essas variáveis é que seria possível explicar a razão de num mesmo arranjo institucional, o resultado da seleção e recrutamento ser tão diferente. Em outras palavras, sob um mesmo arranjo e sob as mesmas leis, partidos ofertam aos eleitores listas de candidatos muito diferentes. Essas diferenças estariam relacionadas, conforme os autores, com processos internos particulares de cada um dos partidos. Seleção e recrutamento seriam apenas aspectos do layout, sem determinar o cenário, mas moldando-o. Os autores propõem tipologias de diferentes espectros que incluem:

1. Tipologia de candidatura: inclui variáveis legais, como o tamanho dos distritos e o tipo de lista, a possibilidade de reeleição e o efeito da incumbência, a organização geográfica do país analisado e a força dos partidos no poder legislativo.

2. Variáveis partidárias: considera as dimensões de Norris e Hazan e Rahat, a saber, quem escolhe candidatos, como a organização partidária o faz e quem financia(rá) os candidatos quando escolhidos.

3. Tipologia legislativa: considera a questão da lealdade partidária, a disciplina, os candidatos que servem suas constituencies e o peso que eles têm no interior delas, bem como considera candidaturas mais independentes (menos “partidárias") e a força de grupos de pressão que podem influenciar a ação de um partido.

Essas variáveis seriam capazes de, em conjunto, evidenciar os "caminhos para o poder" enfrentados pelos (pré)candidatos até a integração da lista e a eleição. O ponto central desta análise, entretanto, reside em mostrar que o regimento do recrutamento e da seleção de candidatos não surge apenas como resposta às instituições políticas, mas emergem da complexa interação de variáveis formais e informais, institucionais e partidárias. Assim, os dois processos, recrutamento e seleção, seriam delineados por

\footnotetext{
${ }^{25}$ Vale ressaltar aqui que os autores usam o termo com uma conotação diferente daquela utilizada pela geografia eleitoral; relaciona-se com as escolhas que partidos fazem em seu interior, apenas.
} 
instituições formais e informais que precisam ser analisadas para a compreensão da seleção de candidatos dos partidos.

São nesses moldes que a literatura internacional desenvolveu os estudos sobre a seleção de candidatos e o recrutamento político. Se seu início é marcado pela excessiva ênfase nas características de perfil dos indivíduos e de uma elite política - característicos do behaviorismo -, por outro, seu maior desenvolvimento se deu sob a vertente neoinstitucionalista, que acrescentou à análise a dimensão institucional. Ela, no entanto, têm se mostrado insuficiente quando circunscrita às instituições formais, e as propostas seguem pela inclusão de variáveis contextuais e informais de cada um dos partidos (por exemplo, Siavelis e Morgenstern, 2008).

É preciso ressaltar que muito do que foi produzido são análises que permanecem na descrição dos processos, ou no delineamento de tipologias cuja pretensão é tornar esses processos comparáveis, ou gerais. Há grande mérito no que foi desenvolvido até aqui, uma vez que estes estudos se baseiam teórica e empiricamente nestes trabalhos. Entretanto, a consequência disso é que análises que contemplam as questões de outras perspectivas, de forma mais analítica e que se centram em investigar o que está por trás das escolhas quando da formação da lista praticamente inexistem, bem como estudos que buscam compreender a ação estratégica que partidos podem ter ao formular suas listas de candidatos. Como será mostrado, esse problema persiste nos estudos do caso brasileiro. 


\section{2 - Os termos do debate brasileiro}

É recente o debate sobre recrutamento e seleção de candidatos no Brasil. Dada sua incipiência, o debate e transição do paradigma behaviorista para o neoinstitucionalista nunca foi uma questão nos trabalhos nacionais. Além disso, são modestos os avanços dessa literatura em comparação com os estudos internacionais. Como consequência, poucas são as incursões sobre a dimensão estratégica da lista de candidatos, elas são apenas apontamentos modestos sobre a possibilidade do uso tático, com singelas contribuições nesse sentido.

A literatura nacional é muito influenciada pelas análises previamente expostas. Norris (1993) e Hazan e Rahat (2010) são a fonte na qual bebem, extensivamente. Deles adotam não apenas a metodologia, mas também a conceituação teórica e a forma de operacionalizar os trabalhos. A vantagem óbvia desse movimento é se apropriar de uma metodologia em algum grau consolidada para explorar um problema inédito. Por outro lado, o alcance da pesquisa fica limitado a essa metodologia, e os problemas que acometem aquela literatura acometerão esta também. Ou seja, da mesma forma que aquela literatura é demasiadamente descritiva, apontando como funcionam os processos e avança pouco analiticamente, a literatura nacional sofre dos mesmos infortúnios. Há que se considerar que esse problema seja, talvez, uma consequência de sua condição ainda embrionária. Seja como for, não deixa de ser um fato.

\subsection{1 - O Recrutamento Político e Seleção de Candidatos no Brasil}

A produção brasileira sobre recrutamento político e seleção de candidatos começou a surgir no início dos anos 2000. Neste período, a ciência política nacional concentrava-se em rebater os diagnósticos sombrios feitos sobre o sistema político-eleitoral brasileiro (Ames, 1995b, 2003; Lamounier, 1992; Mainwaring, 1990, 1991, 1999; Pereira \& Mueller, 2003; Pereira \& Renno, 2007; Samuels, 2002). Essa literatura apontava para a fragilidade do sistema eleitoral brasileiro dada uma dita inexistência de partidos enquanto organizadores do sistema eleitoral. Um dos principais responsáveis por isso seria a representação proporcional de lista aberta, que dada sua permissividade, levaria à mingua o controle partidário sobre os candidatos. Além disso, o fato da lista acabar sendo ordenada pela preferência de voto evidenciaria o baixo controle das lideranças 
sobre elas, o que incentivaria ainda mais o comportamento individualista, já que candidatos de um mesmo partido disputariam entre si por ter seus nomes na lista de candidatos (e de eleitos).

Inversamente, a pretensão da literatura era mostrar que partidos atuam como organizadores do processo de recrutamento e seleção e, assim, são atores centrais no processo pré e eleitoral nacional, e não agentes coletivos esvaziados e distantes da ação e controle político. Nesse sentido, a produção brasileira se centra na compreensão dos fenômenos de recrutamento e seleção pelos caminhos apontados por Norris e Hazan e Rahat, aplicados e adaptados ao contexto brasileiro.

Seguindo a linha argumentativa das análises de Norris, Rodrigues (2002, 2006) mostra que o pertencimento de candidatos eleitos a setores sociais específicos (empresários, profissionais liberais, educadores e burocratas) e de níveis altos/baixos de escolaridade é um fator essencial para compreender o recrutamento. O autor argumenta que há um viés de classe no recrutamento e que ele também se apresenta na seleção dos candidatos. Atenta para uma maior popularização da classe política brasileira, uma resposta partidária à influência da eleição do presidente Lula/PT (2006). Nessa mesma direção, Santos (2003) mostra, ao comparar os deputados brasileiros, que o perfil social dos candidatos ao longo dos dois períodos é bastante estável; partidos teriam predileções determinadas e pouco voláteis. Já Marenco e Serna (2007b) encontram altas correspondências entre perfis ideológicos e tipos ocupacionais, como o caso dos operários e partidos de esquerda.

Com o desenvolvimento de estudos sobre o perfil dos candidatos, surgiram também os questionamentos sobre como partidos tratam setores sociais pouco beneficiados nos cargos legislativos. Estes incluem trabalhos sobre o déficit da participação de afrodescendentes, mas substancialmente sobre a representação de gênero (Htun e Power, 2006) - e a lei de cotas (Lei n 9100/1995) (Araújo e Alves, 2007; Araújo, 2001a, 2001b, 2009).

A representação feminina, principalmente após as reformulações da lei das eleições e da lei das cotas, ganhou centralidade no debate sobre o recrutamento político. Estudos foram feitos para tentar compreender a razão da sub-representação de gênero e a trajetória das candidatas (Álvares, 2008; Araújo \& Borges, 2013). Nesse caminho, os 
autores apontam para a importância da trajetória política, de um histórico de cargos públicos e dos recursos das campanhas, bem como a influência das associações parceiras e da militância da mulher e do partido ao qual ela pertence.

De forma análoga, Perissinoto e Miríade (2009) evidenciam a relevância significativa de determinadas ocupações/profissões, mas pontuam que, apesar disso, os maiores rendimentos eleitorais vêm aos que pertencem a partidos políticos "grandes" - que têm recursos do governo - e que se declaram como "políticos de profissão". Os que já tiveram algum cargo político controlariam ostensivamente a representação política e seriam os escolhidos, em detrimento dos "amadores" (Perissinotto e Miríade, 2009). A contribuição singular deste trabalho é a inclusão de todos os candidatos na análise e não apenas os vencedores eleitos. Segundo os autores, só a análise de todos aqueles que tiveram a oportunidade de disputar os cargos é capaz de encontrar resultados satisfatórios sobre quais grupos são e não são privilegiados.

Power e Mochel (2009) adicionam que o processo de recrutamento político não é aleatório. A ocorrência de determinados perfis não se daria por mera coincidência ou acaso, mas seria planejada pelos partidos, cujos filtros seriam os responsáveis por gerar obliquidades na formação da classe política. Os autores afirmam que partidos teriam papel preeminente no processo de recrutamento, o que se refletiria na escolha de determinados perfis, mas não discutem diretamente as motivações que levariam partidos a fazerem tais escolhas.

Outros trabalhos traçaram caminhos distintos. Incutido pela falta de compreensão de como funciona a lógica partidária brasileira, Guarnieri (2004) mostrou que as lideranças partidárias contam com importante controle sobre a ordenação e composição das listas eleitorais, uma vez que controlam o acesso dos filiados, as nomeações e as regras internas que estruturam o processo de seleção de candidatos, diferentemente do que apontava a literatura anterior. Além disso, eles podem delimitar o número de candidatos que serão lançados - a fim de controlar a competição e diminuir a competição intrapartidária - de forma que o processo de seleção de candidatos é bastante centralizado.

Esse achado contraria Mainwaring (1999), que advoga pela impotência dos partidos brasileiros e para quem o modelo de seleção de candidatos brasileiro seria do tipo 
descentralizado. Isto é, a seleção ocorreria em âmbitos locais e estaduais de forma que a organização nacional não teria papel algum nesse processo. Assim, uma nomeação para compor a lista dependeria do esforço pessoal de cada candidato em conseguir apoio no nível local ou estadual.

Ora, ainda que isso fosse verdadeiro, ainda que a organização nacional influísse pouco sobre a seleção de candidatos e a organização local fosse a arena decisória da lista de candidatos, da mesma forma o partido estaria presente, uma vez que seriam as lideranças locais que escolheriam os candidatos das listas. Também contrariando Mainwaring, Figueiredo e Limongi (2002) apontaram que a formação das listas eleitorais é uma prerrogativa exclusivamente partidária. Os autores aproximam o caso brasileiro ao caso chileno, o qual segundo Carey e Shugart (1995), dá grande importância à reputação partidária. Os autores citam, ainda, outras importantes formas de controle dos partidos sobre a lista, dentre eles o acesso e a distribuição de tempo de Propaganda Eleitoral Gratuita nos meios de comunicação, como sugerido por Schmitt et al (1999).

Relegando ao segundo plano o objetivo de dar uma resposta às críticas do sistema eleitoral, autores passaram a analisar dimensões específicas da seleção de candidatos. Grande parte dos estudos adotou o "roteiro" metodológico sugerido por Rahat e Hazan (2010), a saber, delimitar quem pode se candidatar, quem seleciona os candidatos, onde a seleção acontece e como se dá essa seleção.

Sobre quem pode se candidatar, Nicolau (2006) faz uma descrição precisa, na qual mostra que é preciso ter, no mínimo, um ano de filiação para se tornar candidato. Outro requisito é que, apesar do voto ser permitido aos analfabetos, todos os candidatos precisam ser alfabetizados e exigência de idade varia, conforme prevê a Constituição Federal $^{26}$. Além disso, o candidato precisa ter um vínculo do tipo domicílio eleitoral, ou seja, precisa ser filiado no país onde quer se candidatar, além de ser de nacionalidade brasileira. Cada candidato só pode concorrer para um cargo de cada vez. Em suma,

\footnotetext{
26 “Art. 14, § 3º inciso VI: a idade mínima de: a) trinta e cinco anos para Presidente e Vice-Presidente da República e Senador; b) trinta anos para Governador e Vice-Governador de Estado e do Distrito Federal; c) vinte e um anos para Deputado Federal, Deputado Estadual ou Distrital, Prefeito, Vice-Prefeito e juiz de paz; d) dezoito anos para Vereador".
} 
essas são as exigências legais sobre quem pode se candidatar. Todos os partidos devem respeitar essas leis, mas eles também têm a prerrogativa de estabelecer leis adicionais, por exemplo, sobre a contribuição financeira dos filiados, ou tempo mínimo de filiação para poder se candidatar a um pleito, como o caso do PT evidencia (Bolognesi, 2013).

Focando a atenção na dimensão organizativa do poder partidário, Braga (2008a) aponta para a indicação partidária de candidatos à lista - e não votação -, evidenciando que há um controle interno extensivo das lideranças partidárias sobre o processo de seleção de candidatos. Também Guarnieri (2011), ao estudar a estrutura de funcionamento e divisão de poder dos partidos, aponta que os partidos ditos enfraquecidos por parte da literatura, na verdade, são partidos nos quais também há coordenação partidária no momento pré-eleitoral. A análise do processo eleitoral possibilitou encontrar uma dinâmica altamente concentrada nas lideranças partidárias.

Observando a segunda dimensão de Hazan e Rahat (2010), quem seleciona, Braga (2008b) e Braga, Veiga e Miríade (2009a) apontaram que as escolhas sobre quem serão os candidatos a deputado federal são endógenas aos partidos (estabelecidas em seus regimentos internos) e realizadas nas convenções estaduais, que como aponta Nicolau (2006) são obrigatórias. Ainda assim, é importante notar, como destacam Power e Mochel (2009), que as convenções servem apenas para ratificar a lista de candidatos cujas decisões já foram tomadas. No mesmo sentido, Nicolau (2006) afirma que convenções têm como função ratificar a escolha dos candidatos que acontece em período anterior. De toda forma, a concentração decisória da escolha nos filiados, ou membros das convenções e nas lideranças partidárias confere centralização partidária à seleção de candidatos no Brasil, como já apontou Guarnieri (2004).

Assim, o lócus da seleção da lista, oficialmente, é a convenção, ainda que as listas sejam formuladas em momento anterior. Sabe-se que a dinâmica dessa formulação varia de partido a partido. Caberia ainda questionar se as escolhas são feitas de forma centralizada ou descentralizada e se são inclusivas ou não, isto é, realizadas por lideranças partidárias somente, ou se elas abrem espaço para a participação de seus filiados. Neste sentido, partidos atuam de maneiras diferentes. A literatura se concentra em avaliar os maiores partidos - ainda que em diferentes eleições - mas, no geral, aponta que o PT é o partido que atua de forma mais descentralizada. 
No PT as escolhas são feitas por filiados, que indicam pré-candidatos para uma posterior aprovação nas convenções, nas quais participam os diretórios partidários (estadual e nacional), compostos por delegados que são eleitos para exercerem tal função e apenas os membros com mais de um ano de filiação podem participar das convenções. Esse processo indica inclusividade no processo, como sugerem Braga (2008b) e Guarnieri (2004). Bolognesi (2013) indica, conforme Friedenberg (2003), que o PT é o partido com processo mais democrático de todos os demais partidos.

Em partidos como o PP e o DEM são as lideranças partidárias que formam a lista. Já no PSDB, a lista de candidatos chega fechada pela cúpula do partido na convenção e então seus convencionados aprovam ou não tal pré-seleção. A escolha da lista, também préelaborada, no PSDB e no PMDB é feita por órgãos executivos, sendo que há consulta de filiados no PSDB, e no PMDB não há seleção por delegados (Bolognesi, 2013). Nestes partidos o tempo de filiação mínima para participar das convenções é de seis meses.

Assim, enquanto o PT tem um processo mais inclusivo, PP e DEM são partidos cuja escolha da lista se dá de forma mais exclusiva, pelas lideranças partidárias. Já o PSDB e o PMDB são partidos que estão entre esses dois extremos. Essas evidências contribuem para estudos que analisam a democracia interna dos partidos.

Com esta diferenciação entre os partidos, Bolognesi (2013) se propõe a verificar se partidos de seleção inclusiva são mais democráticos internamente e, assim, mais representativos do ponto de vista da sociedade. Ainda que sem evidências concretas de que partidos mais inclusivos são mais representativos, o autor afirma a existência de requisitos informais para candidaturas, além de um significativo efeito da incumbência no momento de formar a lista. Soma-se a isso a conclusão de que, de qualquer forma, a seleção de candidatos é um bom indicador da democracia interna dos partidos.

Todavia, a despeito dos avanços sobre a compreensão do perfil daqueles cujos partidos dão a oportunidade de integrar a elite política e a seleção de candidatos, Power e Mochel (2009) evidenciam os problemas dessas análises. Os caminhos seguidos pela literatura produziram descobertas necessárias para a compreensão dos fenômenos do recrutamento e da seleção de candidatos. Entretanto é notável a limitação ditada tanto pelo constante retorno, seja como motivação ou como resposta, às análises pessimistas sobre o sistema eleitoral, quanto pelo caráter precipuamente descritivo das análises. 
Power e Mochel apontam, oportunamente, que apenas a descrição do perfil de candidatos ou a seleção destes por si só são contraproducentes quanto ao objetivo de compreender ambos os processos e suas decorrências. A descrição não dá conta de evidenciar consequências, nem estratégias adotadas pelos partidos no momento préeleitoral. Sendo assim, seria apenas um contar de história, "uma causa em busca de seu efeito" (Power e Mochel, 2009). Além disso, não há conclusões na literatura de como, a partir da lógica da escolha de características pessoais, é possível chegar à lógica da seleção de candidatos e a partir disso formular respostas que deem conta de compreender melhor todo esse processo, bem como compreender as estratégias dos partidos na congruência de formar as listas dos seus candidatos, de forma que estas operem com sucesso no intuito de maximizar os ganhos eleitorais dos partidos.

Numa primeira tentativa mais analítica e menos descritiva, e partindo do pressuposto de que partidos são estratégicos também na escolha de nomes que comporão a lista de candidatos disponível ao eleitor, a literatura que explora as estratégias partidárias eleitorais aponta para algumas outras hipóteses. Nicolau (2006), por exemplo, aponta que há viés na escolha dos nomes que comporão a lista. A quantidade de candidatos nas listas, bem como quem serão eles, dependeria das possibilidades das estratégias dos partidos, suas coligações e da oferta de candidatos.

Além disso, partidos considerariam dois fatores na formação das listas de forma a maximizar os seus ganhos: a diversidade social e a dimensão territorial, em consonância com a literatura de recrutamento político (idem, 2006). Nicolau aponta que partidos tenderiam a privilegiar alguns setores sociais, em detrimento de outros, em consonância com os achados de Rodrigues (2002, 2006) e Santos (2003). Dentre os grupos privilegiados estariam sindicalistas, professores, funcionários públicos, personalidades de destaque, dentre outros.

A preocupação com a ação estratégica dos partidos na formação da lista engendrou estudos sobre as possibilidades de escolha e alocação de candidatos territorialmente (Nicolau, 2006). Nesse sentido, a ponderação sobre os fatores geográficos-espaciais ganhou seu primeiro destaque. A hipótese que partidos alocam candidatos evitando a sobreposição locacional a fim de contornar a competição intrapartidária é apontada por Nicolau (2006), mas não explorada. 
Braga e Amaral (2013) exploram tal sugestão brevemente, mas mais apontando para o seu factível peso do que de fato testando-a. Apontam que ao considerar apenas candidaturas competitivas (com mais de $5 \%$ dos votos válidos), a incidência de sobreposição territorial de candidatos é baixíssima, sendo que na maioria dos municípios não há sobreposição alguma de candidatos (no interior de um mesmo partido). Esses achados evidenciariam estratégias geográficas no lançamento de candidaturas. Nesse mesmo formato analítico, os autores exploram a hipótese da diversidade social. Os autores mostram que há ocorrência de perfis sociais, como os sugeridos por Nicolau (2006), e que estes também não "coabitam”, isto é, candidatos de perfis semelhantes não competem no mesmo espaço. Por fim, apontam que o relativo baixo número de candidatos lançados (frente ao número total possível) evidenciam ação coordenada e coletiva no interior dos partidos quando da elaboração da lista eleitoral, também reiterando Nicolau. Estes pontos também são apontados por Cheibub e Sin (2015). Os autores exploram o uso estratégico da lista de candidatos, como já fora exposto anteriormente, e sugerem explorar estratégias nos distritos eleitorais (p.19).

Estes trabalhos são os únicos a apontarem para o uso estratégico da lista de candidatos. Mas a hipótese da regionalização da lista de candidatos como recurso estratégico partidário, entretanto, não é explorada. Como visto, o debate sobre o papel dos partidos no Brasil, como um todo, pauta-se nos apontamentos feitos ao sistema político adotado quando da instituição da democracia no país. Ainda que muitos trabalhos tenham sido feitos para mostrar que o país dista daquele diagnóstico primeiramente descrito, o cerne de quase todas as questões, principalmente àquelas que tangem à organização partidária - o que inclui os estudos de seleção de candidatos e recrutamento -, está em apontar fatores que confirmem tal distância.

Além disso, como destacado, os estudos se mostraram extensivamente descritivos e pouco analíticos. Isto é, os passos dados em direção a uma maior compreensão, principalmente da formação das listas, em sua maioria, se limitam ao detalhamento de como se dão os processos no interior de cada partido. Ainda que esses passos sejam, de fato, necessários, são poucos os estudos que avançam além deles, rumo às análises dos processos já descritos ou das motivações partidárias que permanecem ocultas no "jardim secreto". 
O balanço dos principais estudos sobre esses dois temas mostrou ainda que parte considerável da literatura brasileira norteia-se pelos estudos internacionais do campo. Vale ressaltar que estes trabalhos que servem como orientação para os estudos nacionais foram realizados em e para contextos norte-americanos e europeus de listas fechadas, em sua maioria. Ainda que eles possam se adaptar muitas vezes ao caso brasileiro, cabe compreender que suas conclusões precisam ser salvaguardadas.

É preciso ressaltar também que o avanço desses estudos está condicionado a formatos de análise, como o sugerido por Hazan e Rahat (2010), mas precisam avançar para além deles. Trabalhos descritivos são de extrema importância, mas dado que os processos estão descritos, é preciso compreender as resultantes deles, refletidas nas listas de candidatos em si.

O tema do recrutamento e da seleção de candidatos é um terreno vasto para análises que permitam a desmistificação das estratégias partidárias, que se iniciam não só na arena legislativa, mas ainda no período pré-eleitoral. Somente com o desenvolvimento dessas investigações será possível tirar o assunto do "jardim secreto" e trazê-lo ao plano principal, possibilitando tanto o conhecimento pontual sobre como os partidos planejam suas listas de candidatos, quanto abrindo o caminho para outros estudos que evidenciem o papel central dos partidos enquanto atores que agem de forma estratégica e racional para contornar incentivos perversos da legislação, como apontados no capítulo 1, e atingir seu objetivo principal de vencer eleições. 


\section{3 - Conclusões parciais}

A seleção de candidatos e o recrutamento político são processos políticos fundamentais para a compreensão do papel dos partidos enquanto organizadores do sistema eleitoral. A relativamente vasta literatura desenvolvida em contextos europeus e norte-americanos contribuiu enormemente não só para o início do desenvolvimento do tema, mas para a formatação dos estudos desenvolvidos recentemente no Brasil.

Balizada por essa literatura, a Ciência Política brasileira promoveu a partir do início dos anos 2000, as primeiras caminhadas rumo à compreensão do papel dos partidos no momento pré-eleitoral. Sua incipiência principalmente quanto às estratégias dos partidos, entretanto, torna claro o limiar analítico do estado atual da literatura brasileira sobre recrutamento e seleção de candidatos. A descrição dos processos de recrutamento e seleção, como eles acontecem, e entre quais atores se dão é fundamental, principalmente para que se possa ir além dos propósitos ilustrativos de como seleção e recrutamento se dão.

Esclarecidos como se dão estes processos - trabalho feito pela literatura -, é preciso transpassar essas análises descritivas e partir para exploração das estratégias partidárias que residem por trás da seleção. Compreender o campo de atuação dos partidos e das possibilidades de gerência tática do processo de seleção de candidatos pré-eleitoral no que tange ao seu aspecto geoespacial é o terreno em que este trabalho se insere.

Dado que partidos, agentes racionais do processo eleitoral, têm prerrogativas para exercer papel preponderante na formação de suas listas, cabe analisar como eles o fazem, qual é a lógica na qual se assentam suas escolhas quando o objetivo é maximizar seus ganhos, contornando os incentivos individualistas causados por parte do sistema eleitoral no qual residem. O capítulo seguinte pretende avançar por tal análise seguindo a sugestão da geografia eleitoral, na qual partidos podem fazer uso da dinâmica inerente ao espaço e, consequentemente à esfera política na qual está inserida toda a arena eleitoral. 


\section{CAPÍTULO 3 - A REGIONALIZAÇÃO DAS ESTRATÉGIAS}

O presente capítulo tem como objetivo analisar a relação entre a lista de candidatos e, a partir da hipótese sugerida pela geografia eleitoral, verificar se há evidências de que partidos enquanto atores com prerrogativas para coordenação no processo eleitoral o fazem estrategicamente por meio da dinâmica inerente do espaço na qual atores políticos estão inseridos. Tal emprego será verificado com base nas escolhas dos candidatos que compõem a lista de candidatos. Quando se toma partidos enquanto atores que decidem ativamente no processo eleitoral - porque têm prerrogativas para tal, e porque é racional fazê-lo (como posto no capítulo 1) -, cabe advogar pela formação da lista enquanto momento estratégico fundamental, e um dos caminhos para a efetivação desta estratégia é fazê-lo regionalmente.

O uso de estratégias regionais pode revelar que partidos se apropriam da dinâmica geoespacial e com isso conseguem contornar incentivos perversos da legislação, a saber, a competição intrapartidária. Em outras palavras, a alocação regional de candidatos pode evitar que candidatos de um mesmo partido disputem votos espacialmente coincidentes, canibalizando-se. Ao livrar-se da competição interna, partidos podem maximizar seus ganhos sob os menores custos uma vez que em cada uma das regiões dos distritos eles podem investir apenas no número adequado de candidaturas competitivas em meio a outros candidatos cujo perfil é "menos decisivo" e, portanto, despende menos recursos (partidário e financeiro) aos partidos. Como sugeriram Cheibub e Sin (2015), diminuir a competição no interior das agremiações pode garantir um processo eleitoral com maior certeza, dado que dependeria apenas da competição entre partidos.

Isto é o que será tratado a seguir. Essa análise que articula a ação partidária e uma dimensão geoespacial requer, vale ressaltar, um duplo esforço. O primeiro é sobre a questão geográfica. A subdivisão regional dos distritos para a observação do fenômeno não pode ser definida por critérios ad hoc já que a lógica eleitoral estaria sujeita a ela, e não o contrário. Assim, é preciso identificar uma definição das regiões que seja reflexo da dinâmica geoespacial, e não da dinâmica política propriamente. Isto posto, o segundo 
esforço está em entrelaçar o elemento geoespacial contextual ${ }^{27}$ e a dinâmica política. É nesta arena não-política, mas engendrada pelo mundo socioespacial, que será possível identificar a presença de estratégias regionais na formação das listas por parte dos partidos.

Dado que a competição intrapartidária e, consequentemente, os incentivos individualistas aos candidatos tendem a ser, teoricamente, maiores quanto mais elevada for a magnitude do distrito, São Paulo, o caso extremo, será objeto de análise neste capítulo. Com magnitude $\mathrm{M}=70$, a identificação de uma lógica regional de competição requer organização partidária. Assim, os partidos analisados serão os cinco maiores partidos nacionais ao longo das últimas quatro eleições - de 2002 a 2014. Inicialmente, o caso de São Paulo será apresentado frente ao cenário nacional. Em seguida, o trabalho se concentrará no esforço da identificação das regiões do distrito selecionado. Por fim, será apresentada a análise das listas de candidatos dos partidos escolhidos frente à dimensão regional.

\footnotetext{
${ }^{27}$ Ver capítulo 1.
} 


\section{1 - A lista de candidatos e São Paulo, o caso extremo}

Conforme discutido no capítulo anterior, os passos para a formação da lista de candidatos, bem como a descrição das particularidades de cada partido são bastante discutidos na literatura nacional. São discutidos como e quem forma as listas (Bolognesi, 2013; Braga \& Amaral, 2013), como cada partido encaminha esses procedimentos de acordo com a sua estrutura organizacional interna (Bolognesi, 2013; Braga, 2008; Guarnieri, 2004) e o perfil dos selecionados em cada pleito (Braga, Veiga, \& Miríade, 2009; Marenco \& Serna, 2007; Perissinotto \& Miríade, 2009). No entanto, a dimensão estratégica que a lista de candidatos pode ter, conforme sugerido por Norris (1993), Cheibub e Sin (2015) e Latner e McGann (2005), é apenas lateralmente apontada.

O principal fator apontado como evidência de ação partidária estratégica das listas é o número de candidatos lançados por cada partido. Braga e Amaral (2013) e Guarnieri (2004) são endossados por Cheibub e Sin (2015) neste argumento. No geral, segundo os autores, o número de candidatos na lista ficaria muito abaixo do limite permitido em todos os pleitos. Este limite é definido pela Lei das Eleições ( $n^{\circ}$ 9.504/1997), que estabelece que

Art. 10. Cada partido ou coligação poderá registrar candidatos para a Câmara dos Deputados (...) no total de até $150 \%$ (...) do número de lugares a preencher, salvo:

I - nas unidades da Federação em que o número de lugares a preencher para a Câmara dos Deputados não exceder a doze, nas quais cada partido ou coligação poderá registrar candidatos a Deputado Federal (...) no total de até $200 \%$ (duzentos por cento) das respectivas vagas; (...).

Ou seja, para as eleições para o Legislativo nacional, a regra pode ser simplificada da seguinte maneira: quando a magnitude do distrito em questão for inferior a 12, partidos ou coligações podem apresentar uma lista de até 2 vezes o número de cadeiras daquele distrito; quando a magnitude do distrito exceder 12, partidos podem apresentar até 1,5 vez o número de cadeiras do distrito. Isso implica que em São Paulo, em que a magnitude é igual a $\mathrm{M}=70$, um partido pode apresentar até 105 candidatos na sua lista. A distribuição da porcentagem de candidatos lançados por partidos em relação ao total 
permitido por distritos mostra que, de fato, a mediana das porcentagens é baixa, indicando que partidos lançam poucos candidatos frente ao total permitido ${ }^{28}$, exceto os casos em que totalizam o número de candidatos lançados no interior de uma coligação (casos que ultrapassam o $100 \%$ do total permitido, conforme a figura abaixo - conferir nota 2$)^{29}$.

\section{Gráfico 1 - \% de candidatos lançados em relação ao permitido por UF por ano, ordenados pela magnitude dos distritos, da menor para a maior ${ }^{30}$}
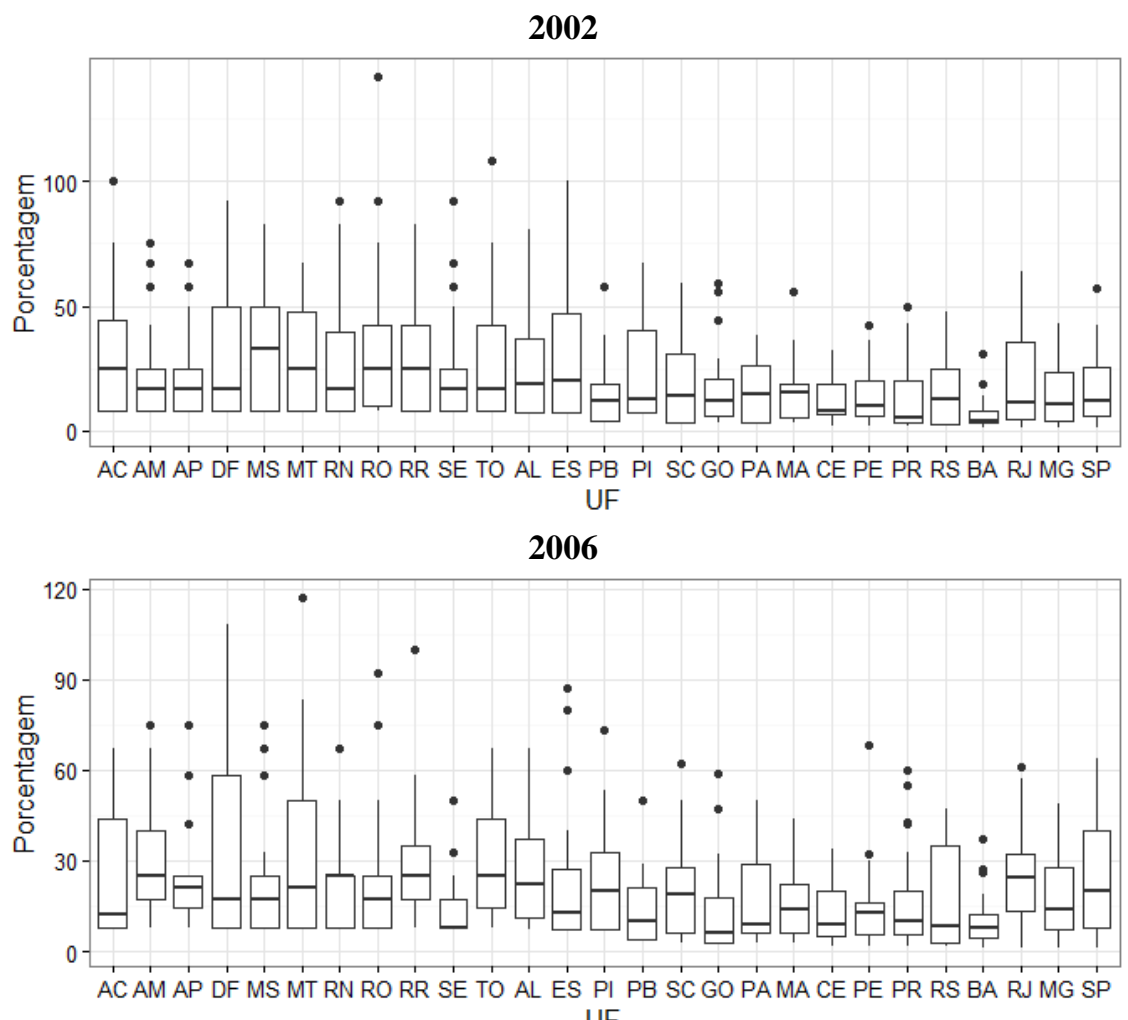

UF

${ }^{28}$ O número, conforme o cálculo feito, só ultrapassa $100 \%$ quando um partido lança mais do que o permitido porque integra uma coligação. Esses casos acontecem poucas vezes: em dois estados em 2002 (RO e TO), em dois em 2006 (DF e MT), em nenhum em 2010 e em seis estados em 2014 (DF, MS, MT, RN e AL e ES).

${ }^{29}$ Coligações não serão analisadas neste trabalho dado que é impossível afirmar se partidos que não “ocupam" vagas dos demais partidos coligados estão ou não empregando estratégias que consideram a coligação como um todo.

${ }^{30}$ Para conferir a magnitude de cada um dos distritos, ver anexo 1. 


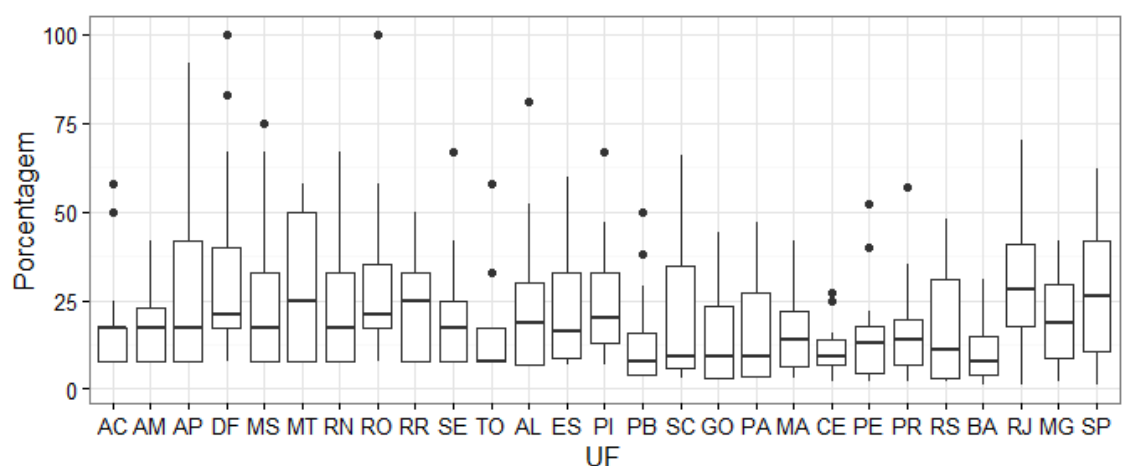

2014

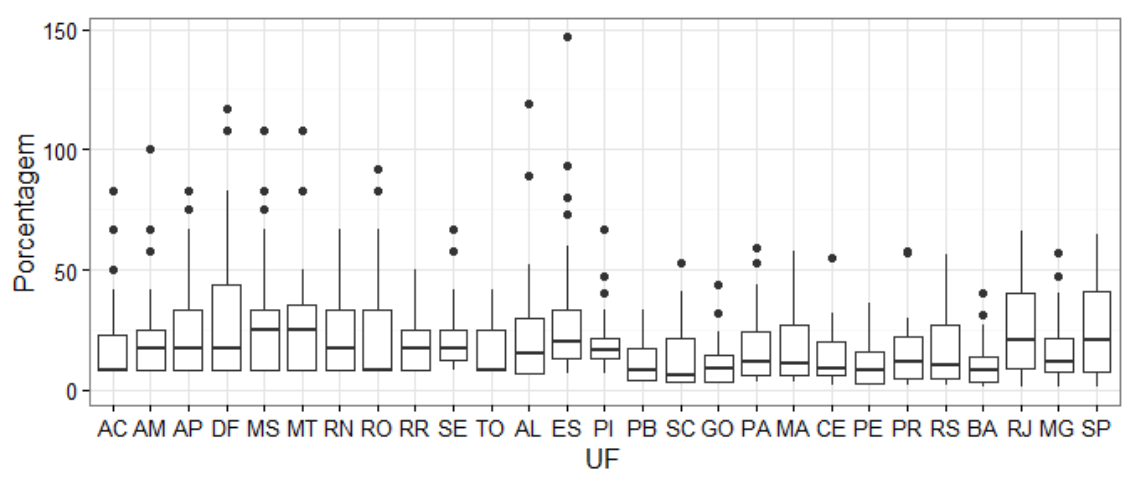

Fonte: TSE. Elaboração Própria.

A mediana da porcentagem de candidatos lançados em relação ao total permitido fica sempre abaixo de $50 \%$ em todo o país. Isto é, partidos no geral apresentam menos candidatos em suas listas do que a metade do total prescrito em lei. Nessa faixa se encaixa, vale notar, o caso do estado de São Paulo. Os partidos no estado paulista apresentaram, no máximo, cerca de $60 \%$ do total em relação à sua magnitude.

Ora, o caso de São Paulo representa, como discutido anteriormente, o caso mais extremo para o argumento do esvaziamento do papel dos partidos como consequência da lista aberta e da magnitude elevada. Ainda assim, é um estado que apresenta um número de candidatos à lista inferior ao total possível. Se a literatura tem razão em afirmar que uma lista partidária menor é reflexo de ações coordenadas dos partidos, então o argumento de que partidos coordenam o processo eleitoral porque têm meios para tal (Norris, 1993) encontra aqui seus primeiros reflexos.

Do estado de São Paulo, foram escolhidos os cinco maiores partidos nacionais (escolhidos de acordo com a sua bancada eleita nos pleitos analisados neste trabalho). A escolha destes partidos almeja um critério exógeno a São Paulo. Além disso, são nesses partidos que a chance de sucesso eleitoral é maior, dado que são os que mais elegem 
candidatos. Estes partidos têm as listas de candidatos nas quais, em teoria, mais candidatos querem estar. Consequentemente, o fato do número de candidatos neles ser menor que o total permitido não se relacionaria com uma baixa procura de cidadãos pela possibilidade de possuir postos eletivos.

Em outras palavras, como são partidos nos quais candidatos têm maiores chances de vencer, o número baixo de candidatos tem pouca possibilidade de estar relacionado com uma indisponibilidade de cidadãos interessados em concorrer aos cargos políticos. Dados os baixos níveis de identificação partidária no país (Kinzo, 2004) - 71\% dos brasileiros não tem preferência por partido algum, segundo o Datafolha ${ }^{31}$ - candidatos de outros partidos menores poderiam migrar para os partidos maiores e aumentar, portanto, suas chances de vitória. Mas isso não acontece: sistematicamente o número de candidatos lançados por esses partidos é inferior ao limite superior permitido. A tabela 1 ilustra a continuidade das mesmas siglas partidárias conquistando a maioria das cadeiras ao longo dos últimos cinco pleitos:

\begin{tabular}{|c|c|c|c|c|}
\hline \multirow[b]{2}{*}{ Partido } & \multicolumn{4}{|c|}{$\%$ Cadeiras } \\
\hline & 2002 & 2006 & 2010 & 2014 \\
\hline PT & $18 \%$ & $17 \%$ & $17 \%$ & $13 \%$ \\
\hline PMDB & $16 \%$ & $16 \%$ & $15 \%$ & $13 \%$ \\
\hline PSDB & $15 \%$ & $13 \%$ & $11 \%$ & $11 \%$ \\
\hline PPB/PP & $14 \%$ & $13 \%$ & $9 \%$ & $7 \%$ \\
\hline PFL/DEM ${ }^{32}$ & $10 \%$ & $8 \%$ & $8 \%$ & - \\
\hline PSD $^{33}$ & - & - & - & $7 \%$ \\
\hline Total & $72 \%$ & $67 \%$ & $59 \%$ & $51 \%$ \\
\hline
\end{tabular}

Conforme evidencia a tabela 1, os maiores partidos nacionais mantêm o posto ao longo dos pleitos. Com exceção do PFL/DEM que em 2014 perdeu o quinto lugar para o PSD

\footnotetext{
${ }^{31}$ Pesquisa de Fevereiro/2015. Este valor corresponde ao menor da série histórica, que se inicia em 1989. Mais detalhes, ver http://goo.gl/D9kLmT.

32 O PFL/DEM, em 2014, obteve apenas $4 \%$ das cadeiras, sendo o $10^{\circ}$ partido mais votado. Seguindo o critério adotado - analisar os cinco maiores partidos nacionais -, ele foi substituído nesta análise pelo $5^{\circ}$ mais votado em 2014, isto, é, o PSD.

${ }^{33}$ O PSD só foi criado em setembro de 2011. Ver http://goo.gl/t7qkvG.
} 
(fruto de dissidências internas do próprio PFL/DEM), os quatro maiores "vencedores" das eleições para o Legislativo federal são os mesmos: PT, PMDB, PSDB e PPB/PP.

Essa obtenção constante de cadeiras ao longo do território nacional evidencia que estes partidos são os quais possuem maior organização - seja centralizada ou não ${ }^{34}$ - do ponto de vista eleitoral. Essa organização engendraria a "grandeza" destes partidos também no nível estadual, conforme a Tabela 2:

Tabela 2 - \% de Cadeiras e Candidatos Lançados Pelos 5 Maiores Partidos Nacionais em SP

\begin{tabular}{|c|c|c|c|c|c|c|c|c|}
\hline \multirow[b]{2}{*}{ Partido } & \multicolumn{2}{|c|}{2002} & \multicolumn{2}{|c|}{2006} & \multicolumn{2}{|c|}{2010} & \multicolumn{2}{|c|}{2014} \\
\hline & $\begin{array}{c}\text { Candidatos } \\
\text { Lançados }\end{array}$ & $\begin{array}{c}\% \\
\text { Cadeiras } \\
\end{array}$ & $\begin{array}{c}\text { Candidatos } \\
\text { Lançados }\end{array}$ & $\begin{array}{c}\% \\
\text { Cadeiras } \\
\end{array}$ & $\begin{array}{c}\text { Candidatos } \\
\text { Lançados }\end{array}$ & $\begin{array}{c}\% \\
\text { Cadeiras } \\
\end{array}$ & $\begin{array}{c}\text { Candidatos } \\
\text { Lançados }\end{array}$ & $\begin{array}{c}\% \\
\text { Cadeiras } \\
\end{array}$ \\
\hline PMDB & 36 & $6 \%$ & 39 & $4 \%$ & 68 & $1 \%$ & 90 & $6 \%$ \\
\hline PPB/PP & 37 & $4 \%$ & 37 & $7 \%$ & 71 & $6 \%$ & 20 & $3 \%$ \\
\hline PSDB & 43 & $16 \%$ & 75 & $26 \%$ & 52 & $19 \%$ & 59 & $4 \%$ \\
\hline PT & 60 & $26 \%$ & 60 & $20 \%$ & 63 & $21 \%$ & 69 & $20 \%$ \\
\hline PFL/DEM & 58 & $10 \%$ & 39 & $7 \%$ & 31 & $9 \%$ & - & - \\
\hline PSD & - & - & - & - & - & - & 23 & $14 \%$ \\
\hline Total & 234 & $61 \%$ & 250 & $64 \%$ & 285 & $56 \%$ & 261 & $47 \%$ \\
\hline
\end{tabular}

Os partidos selecionados têm também em São Paulo notável relevância, representando juntos a maioria das cadeiras conquistadas nos pleitos (com exceção de 2014, que conquistam juntos $47 \%$ das 70 cadeiras do distrito).

Isto posto, se para os partidos é racional distribuir os candidatos ao longo do território (como argumento do capítulo 1), cabe questionar como eles alocam esses candidatos ao regionalmente. Para tal, é preciso empreender esforços para encontrar uma definição das regiões conforme sugerem os trabalhos que apontam para a importância do contexto geoespacial sobre o mundo social e político.

\footnotetext{
${ }^{34}$ Ver Guarnieri, 2011.
} 


\section{2 - A dinâmica regional: definindo as regiões}

$\mathrm{O}$ argumento da geografia eleitoral, de que uma dinâmica intrínseca ao mundo social ditada pelo espaço é a base para o mundo político de forma que este é balizado e influenciado por características sociais que irrompem conforme o local, pressupõe uma definição de regiões aprimorada. As regiões as quais a teoria se refere não podem ser fruto de decisões políticas ou reflexos dela (da política) porque, conforme o argumento, é o layer político que está posto sob o plano geoespacial. Essa definiç̧ão precisa conferir às regiões, portanto, um caráter exógeno à política.

Desse modo, a despeito da organização política, a definição das regiões para a geografia eleitoral supõe uma definição mais simples, não necessariamente institucionalmente formal, mas que dê conta de captar a dinâmica que é criada pela própria disposição territorial e social. Em outras palavras, as regiões do distrito precisam ser delimitadas pelos movimentos criados pelo espaço geográfico que baliza o cotidiano das pessoas, o fluxo de informações que chega até elas. Definições tradicionalmente adotadas, como a das regiões administrativas - formalmente instituídas pela primeira vez em $1970^{35}$-, portanto, não são adequadas para tal propósito, dado que foram politicamente decididas e impostas à dinâmica geoespacial inerente ao environment (Huckfeldt e Sprague, 1987).

Nesse sentido, o Instituto Brasileiro de Geografia e Estatística, IBGE, fornece uma alternativa bastante adequada à proposta teórica em questão. A "Regiões de Influência das Cidades" (Regic) foi desenvolvida com o intuito de encontrar uma divisão do país em regiões funcionais. Estas regiões funcionais correspondem aos relacionamentos hierárquicos estabelecidos entre cada uma das cidades brasileiras que, em conjunto, formam a rede urbana brasileira. Conforme a pesquisa da Regic,

"a ideia de rede [...] chama a atenção para a complexidade das interações espaciais, resultantes do conjunto de ações desencadeadas em lugares mais ou menos longínquos" (Dias, 2005, p. 23), num processo que leva à difusão de funções urbanas de nível médio, pela redução dos limiares necessários à sua instalação. (Regic IBGE, 2007, p. 9).

\footnotetext{
35 Desde sua instituição a divisão das regiões administrativas sofre alterações. A mais recente, por exemplo, foi a criação da $16^{\circ}$ Região Administrativa - Sorocaba em 2014.
} 
Os nós "de referência" da rede seriam formados por aquelas cidades que constituem localidades centrais (para cada um dos níveis nacional, estadual, regional), em níveis hierarquicamente mais altos e, ao seu redor, os municípios que ficam no entorno desses centros, de hierarquia mais baixa. O estabelecimento desses nós centrais seria dado pelo desenvolvimento de elevados níveis de fluxos econômicos e materiais, característico dos polos regionais, os quais carecem os municípios de nível inferior na cadeia hierárquica. Esses níveis de hierarquia se dividem em categorias que vão desde "Grande Metrópole Nacional (1A)" para o caso de São Paulo, até o nível 5, em que encontram-se as cidades de hierarquia mais baixa ${ }^{36}$. A tabela abaixo exemplifica:

Tabela 3 - Níveis de hierarquia dos municípios brasileiros - Regic/IBGE

\begin{tabular}{cll}
\hline \hline Classificação & Hierarquia & Cidades e Características \\
\hline 1A & Grande Metrópole Nacional & São Paulo \\
1B & Metrópole Nacional & Rio de Janeiro e Brasília \\
1C & Metrópole & Manaus, Belém, Fortaleza, Recife, Salvador, BH, Curitiba, Goiânia, Porto Alegre \\
2A & Capital Regional A & 11 cidades; aproximadamente 955 mil habitantes e 487 relacionamentos \\
2B & Capital Regional B & 20 cidades; aproximadamente 435 mil habitantes e 406 relacionamentos \\
2C & Capital Regional C & 39 cidades; aproximadamente 250 mil habitantes e 162 relacionamentos \\
3A & Centro Sub-regional A & 85 cidades; aproximadamente 95 mil habitantes e 112 relacionamentos \\
3B & Centro Sub-regional B & 79 cidades; aproximadamente 71 mil habitantes e 71 relacionamentos \\
4A & Centro Zona A & 192 cidades; aproximadamente 45 mil habitantes e 49 relacionamentos \\
4B & Centro Zona B & 364 cidades; aproximadamente 23 mil habitantes e 16 relacionamentos \\
5 & Centro local & 4473 cidades; menos de 10 mil habitantes \\
\hline
\end{tabular}

Fonte: IBGE. Elaboração Própria.

Num plano prático, a definição das cidades polo regionais se deu com base no nível de desenvolvimento que elas possuem de serviços como saúde, fluxos de comércio, ligações aéreas com outras regiões, cobertura de emissoras de televisão, jornais locais e instituições de ensino superior. Estes são os diferenciais que dotam centralidade às cidades, e elevam seu nível hierárquico frente às demais cidades da pesquisa. De maneira inversa, municípios com menos oferta desses serviços - localizados ao redor das cidades polo - dependem da estrutura das cidades mais centrais, sendo que são limitados por questões propriamente geográficas como a distância/proximidade entre municípios e a oferta de malha rodoviária viável.

\footnotetext{
${ }^{36}$ Detalhes da operacionalização encontram-se no anexo 2.
} 
A Regic foi desenvolvida com base numa série de questionários aplicados numa amostra de municípios que corresponde a $83 \%$ de todos os 5.564 municípios brasileiros. Estes questionários investigaram as ligações de transporte regulares entre municípios e o destino dos moradores para a obtenção de serviços como educação superior, saúde, compras em geral e aeroportos. Com base nesses questionários, foram definidas a hierarquia, as áreas de influência das cidades, a articulação entre os municípios e a rede de cidades. Nas palavras dos autores,

buscou-se definir a hierarquia dos centros urbanos e delimitar as regiões de influência a eles associadas a partir dos aspectos de gestão federal e empresarial e da dotação de equipamentos e serviços, de modo a identificar os pontos do território a partir dos quais são emitidas decisões e é exercido o comando em uma rede de cidades. (Regic IBGE, 2007).

Assim, a hierarquização dos municípios originou cada uma das regiões de influencia dessas cidades de hierarquia mais elevada (conforme a tabela 3). Isto é, municípios de hierarquia mais elevada constituíram-se como polos regionais para cidades de hierarquia menor, que ficam ao seu redor e, com eles, estabelecem relações de comércio, fluxo de pessoas, transporte, educação e saúde, por exemplo.

À parte da arena política, e baseada exclusivamente em questões geográficas e socioeconômicas, a Regic é uma alternativa razoável para o problema posto pela geografia eleitoral. Abrangente, as regiões definidas pela pesquisa são moldadas de acordo com a fluidez de pessoas e informações pela malha de cidades; fluidez esta criada e naturalizada pelo espaço geográfico nos quais as cidades estão inseridas e que, de forma muito elementar, dita para onde vão e o que chega até os moradores de cada uma das cidades brasileiras. Ela é, assim, a rede que será utilizada para a definição das regiões neste trabalho, seguindo a teoria da geografia eleitoral.

\subsection{1 - A rede de São Paulo}

O estado de São Paulo é composto por 645 municípios e a Regic os distribui entre 15 diferentes regiões. Sua capital, São Paulo, na classificação de cidades da pesquisa, é o 
município de nível mais elevado, ou a "Grande metrópole nacional". Dessa forma, a cidade de São Paulo influencia todas as demais cidades do estado, a despeito delas pertencerem a regiões cuja cidade polo é outra. Isso não anula ou diminui a influência das cidades polo regionais, mas indica que as informações que circulam por São Paulo frequentemente atingem também outros municípios mais distantes. Basta pensar na distribuição de jornais: enquanto o jornal do município do extremo oeste do estado não circula na capital, jornais como "O Estado de São Paulo", ou "A Folha de São Paulo", cuja cidade de origem é São Paulo, circulam por todas as cidades do estado - e, vale dizer, do país. A distribuição dos municípios do estado na rede está disposta conforme expõe o Mapa 1.

\section{Mapa 1 - A rede de municípios do estado de São Paulo}

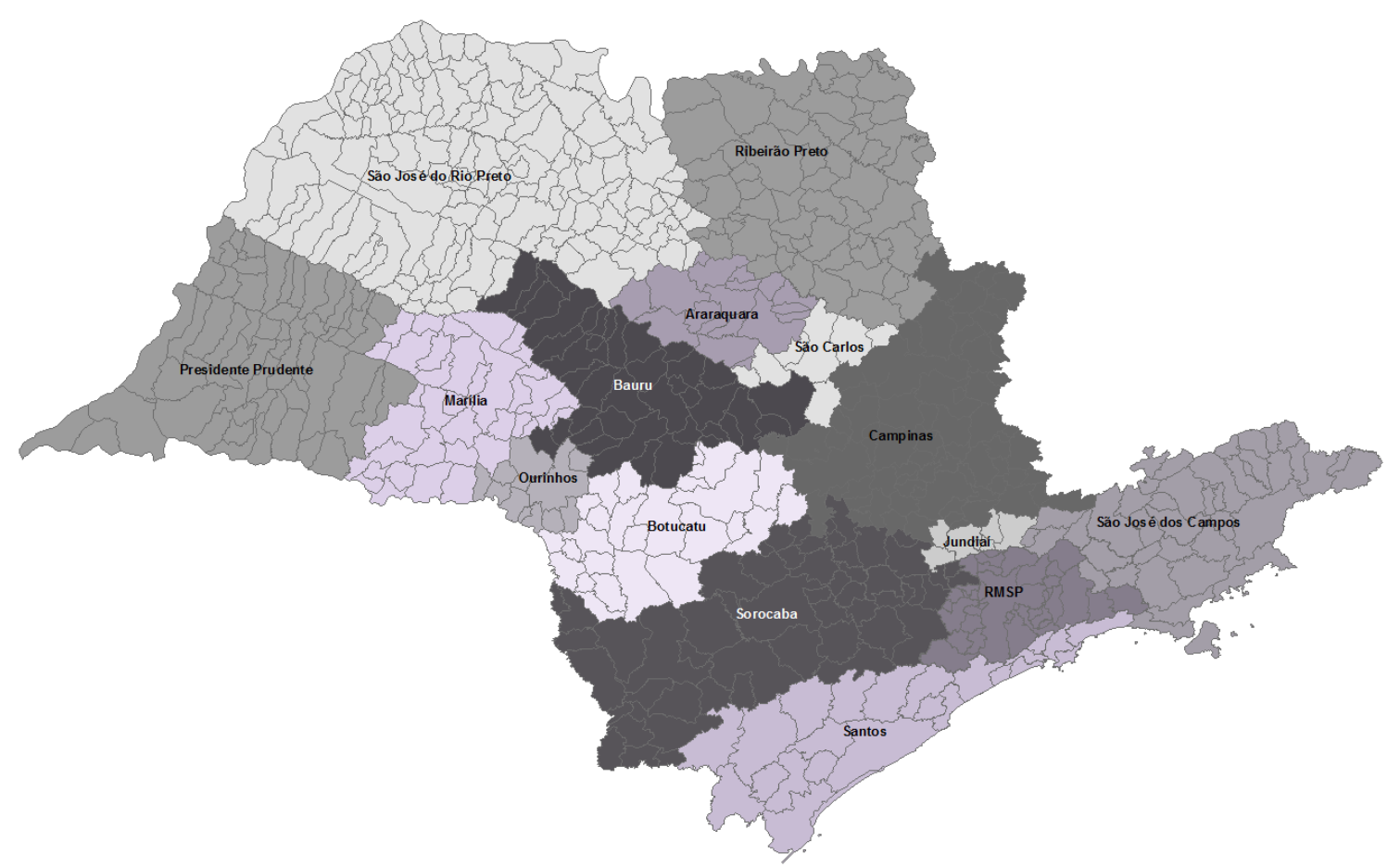

Fontes: Regic-IBGE; Base-shp: CEM/Cebrap. Elaboração Própria.

Essas quinze regiões, nomeadas pelas cidades polo (de maior hierarquia) de cada uma delas, conforme a tabela abaixo, são compostas por: 
Tabela 4 - Rede Urbana - São Paulo e População

\begin{tabular}{cccccc}
\hline \hline \multirow{2}{*}{$\begin{array}{c}\text { Municípios de } \\
\text { Referência }\end{array}$} & \multirow{2}{*}{ No municípios } & \multicolumn{4}{c}{ População } \\
\cline { 3 - 6 } & 18 & $\mathbf{2 0 0 2}$ & $\mathbf{2 0 0 6}$ & $\mathbf{2 0 1 0}$ & $\mathbf{2 0 1 4}$ \\
\hline Araraquara & 39 & 968.988 & 1.049 .894 & 1.067 .978 & 1.136 .219 \\
Bauru & 26 & 449.595 & 479.668 & 501.080 & 534.794 \\
Botucatu & 77 & 4.634 .534 & 5.085 .759 & 5.356 .156 & 5.774 .324 \\
Campinas & 7 & 667.528 & 728.640 & 788.202 & 854.623 \\
Jundiaí & 36 & 675.602 & 706.708 & 714.680 & 729.784 \\
Marília & 11 & 202.942 & 211.368 & 219.277 & 231.944 \\
Ourinhos & 57 & 807.163 & 831.240 & 851.258 & 915.305 \\
Presidente Prudente & 62 & 17.769 .576 & 19.084 .436 & 19.533 .584 & 20.765 .991 \\
Ribeirão Preto & 36 & 2.050 .741 & 2.191 .432 & 2.320 .385 & 2.487 .053 \\
RMSP & 24 & 1.747 .135 & 1.878 .790 & 1.937 .702 & 2.065 .208 \\
Santos & 7 & 328.506 & 353.312 & 371.408 & 397.998 \\
São Carlos & 147 & 2.071 .875 & 2.190 .422 & 2.281 .178 & 2.426 .203 \\
São José do Rio Preto & 43 & 2.065 .084 & 2.233 .498 & 2.351 .676 & 2.525 .073 \\
São José dos Campos & 55 & 2.085 .204 & 2.265 .387 & 2.403 .261 & 2.588 .956 \\
Sorocaba & $\mathbf{6 4 5}$ & $\mathbf{3 7 . 0 3 4 . 4 0 5}$ & $\mathbf{3 9 . 8 2 9 . 5 7 5}$ & $\mathbf{4 1 . 2 6 4 . 2 0 8}$ & $\mathbf{4 4 . 0 3 7 . 3 1 8}$ \\
\hline Total & & & &
\end{tabular}

Fonte: IBGE. Elaboração Própria.

A rede de influência dos municípios implica que um cidadão que mora numa cidade vizinha à Campinas, por exemplo, busque serviços em Campinas, e não em Botucatu. Ou ainda, que as informações locais que circulam ao redor dos municípios de São José dos Campos venham de São José dos Campos, e não de Ribeirão Preto. Cada uma dessas regiões teria uma dinâmica interna própria que atinge somente municípios que pertencem à sua rede, e não os demais. O princípio elementar é que a informação que flui e circula numa região não circula e flui em outras regiões. Isso se deve às relações de localidade e proximidade que propiciam vieses locais sobre cidadãos: o cidadão de Presidente Prudente tem mais contato e interesse pelas informações, pelo contexto de sua região (cf. Agnew, 1996 $6^{37}$ ), do que informações de São Carlos, por exemplo. Esse fluxo de informações não é intencional, nem se dá por acaso: ele é fruto da dinâmica geoespacial inerente ao mundo social.

A análise sobre a alocação regional da lista de candidatos pelos partidos será feita com base nessa divisão regional instituída pela dinâmica que a Regic captou. O desafio que segue é verificar se essas regiões dão real sentido à dinâmica do mundo político. Uma primeira etapa disso será associar os políticos da lista de candidatos à cada uma das 15 regiões estabelecidas pela Regic.

\footnotetext{
${ }^{37}$ Ver discussão no capítulo 1.
} 


\section{3 - As regiões e os candidatos}

Se Shugart e Carey (1995) advogaram pela importância crucial do comportamento personalista em relação ao eleitorado em sistemas de representação proporcional de lista aberta, dez anos depois Shugart et al. (2005) apontaram que os atributos pessoais dos candidatos são centrais na obtenção de votos em sistemas com este arranjo eleitoral. Esses atributos, nas palavras dos autores,

$$
\begin{aligned}
& \text { são potencialmente mais valiosos frente ao eleitorado que o } \\
& \text { comportamento orientado às constituencies primeiramente apontado } \\
& \text { pela literatura do "voto pessoal" (Shugart et al, 2005, p.438) }
\end{aligned}
$$

O argumento é que estes atributos não podem ser alterados ou construídos pelos candidatos, eles são fixos. E por isso podem constituir importantes atalhos para os eleitores num sistema em que oferta de candidatos a cada pleito por cada partido é grande, o que torna difícil a diferenciação e a escolha do eleitor por um único candidato. Os atributos pessoais dos candidatos não são uma questão de escolha deliberada ou não dos candidatos, mas uma questão substancial e objetiva frente ao eleitorado.

Nesse sentido, os autores apontam em consonância com Gallagher (1988) que estes atributos pessoais, no geral, se relacionam com as raízes locais dos candidatos. Concretamente, argumentam que experiência política-eleitoral local e origem local são bons indicadores para os eleitores. Isto é, eleitores conhecem estes candidatos e supõem que eles têm conhecimento dos problemas locais, e do local em si. Cain, Ferejohn e Fiorina (1987, p. 221) também apontaram para a possibilidade de adoção da estratégia de recrutamento de figuras políticas localmente conhecidas para a lista de candidatos em distritos de lista aberta e magnitude elevada. Esses candidatos teriam a vantagem da proeminência local e uma maior sensibilidade aos assuntos locais.

Assim, conforme Shugart et al. (2005), dois são os caminhos que tornam possíveis a associação de um candidato à um local: sua origem e suas experiências políticas locais anteriores. Concretamente, serão utilizados para os fins deste trabalho o local de filiação de um candidato e seu histórico de passado político local.

\footnotetext{
${ }^{38}$ Tradução própria.
} 


\subsection{1 - A filiação partidária}

O local de filiação de um candidato permite atribuir um primeiro critério de localidade a um candidato. Para a associação ao local, o total de filiados no estado de São Paulo foi utilizado de maneira que se tornou possível conhecer o histórico geográfico de filiação dos candidatos dos cinco partidos analisados. A tabela 4 evidencia o universo de filiados por partidos no estado, os partidos estão organizados por tamanho de membership:

Tabela 5 - Número de filiados por partido SP

\begin{tabular}{cccc}
\hline \hline Partido & Filiados & Partido & Filiados \\
\hline PMDB & 617.227 & PMN & 50.736 \\
PT & 462.501 & PHS & 43.771 \\
PSDB & 410.414 & SD & 41.557 \\
PTB & 399.544 & PT DO B & 39.234 \\
PPB/PP & 271.153 & PTN & 35.556 \\
PFL/DEM & 227.745 & PSOL & 29.886 \\
PDT & 198.261 & PTC & 27.328 \\
PR & 181.070 & PRTB & 24.207 \\
PSB & 158.955 & PEN & 15.707 \\
PV & 130.483 & PROS & 12.396 \\
PPS & 129.370 & PPL & 6.560 \\
PC DO B & 91.490 & PMB & 4.992 \\
PRP & 80.823 & PSTU & 4.826 \\
PSC & 78.376 & REDE & 2.597 \\
PRB & 72.940 & PCB & 2.589 \\
PSDC & 56.661 & NOVO & 1.685 \\
PSL & 55.379 & PCO & 955 \\
PSD & 53.774 & & \\
\hline & Total & F.020.748 & \\
\hline & & Dados 1o semestre/2016 & TSE. Elaboração própria.
\end{tabular}

Foram analisados todos os 1.030 candidatos lançados pelos cinco maiores partidos nacionais no estado de São Paulo entre 2002 e 2014. Quase a totalidade de candidatos foi encontrada na base de São Paulo (ver tabela 5). Isso implica que, em média, 93\% dos candidatos lançados pelos partidos analisados se filiaram no estado de São Paulo. Aqueles que se filiaram em outros estados foram excluídos desta categoria de análise porque, conforme este critério, não é possível atribuir a eles domicílio eleitoral paulista, ou seja, não é possível afirmar a região ao qual ele pertence. 
Tabela 6 - \% dos candidatos

lançados encontrados na base de

filiados em SP

\begin{tabular}{lc}
\hline \hline Partido & \% dos encontrados \\
\hline PMDB & $99,6 \%$ \\
PT & $97,2 \%$ \\
PPB/PP & $98,2 \%$ \\
PFL/DEM & $68,0 \%$ \\
PSDB & $95,2 \%$ \\
PSD & $100 \%$ \\
\hline
\end{tabular}

Fonte: TSE. Elaboração Própria.

A distribuição do número de candidatos entre os partidos de acordo com a região de filiação deles a cada ano encontra-se no anexo 3.

\subsection{2 - O passado político local}

O segundo critério utilizado para definir a associação de um candidato com uma região é o seu histórico de passado político local. Key (1949) foi o primeiro a apontar que eleitores teriam preferência pelo candidato local. Se por um lado a proximidade faz estreitar laços entre o candidato e o eleitor, de outro, determinados contextos locais expõem eleitores a vieses específicos, fruto da estrutura geoespacial. É nesta estrutura que se assenta a arena política e a vida cotidiana dos eleitores e a exposição originada por ela é responsável por criar e ditar o ritmo do fluxo de informações que fluem pelo território. Esse fluxo de informações é responsável por criar e alterar as preferências políticas dos eleitores.

Dessa forma, concretamente, informações que são geradas numa determinada localidade não chegam até outra naturalmente, a menos que a estrutura sociogeográfica contribua para tal. Isso inclui informações políticas, de campanhas eleitorais. Assim, a campanha do ex-prefeito de Sorocaba a deputado federal atinge os moradores da região de Sorocaba, mas atinge pouco moradores da região de Ribeirão Preto. Da mesma forma que a candidatura do ex-vereador de Santos é mais popular entre o eleitorado da região santista do que entre o eleitorado da região campineira. 
Dada a carência de identificação partidária já citada, outras são as informações que o eleitor leva em consideração ao escolher seus candidatos. Conforme Gallagher (1988) e Shugart et al. (2005) é o seu atributo pessoal cristalizado nas suas raízes locais, que importa, não fatores políticos. Assim, para o argumento da geografia eleitoral, pouco importa o vínculo partidário, ou por qual partido o candidato concorreu nas eleições municipais. Basta saber por qual município (e, consequentemente, por qual região) o candidato já concorreu para associá-lo a determinada localidade. Essa é, portanto, informação que será utilizada nesta análise.

Muitos são os cargos políticos que poderiam tornar um indivíduo politicamente público, como a obtenção de secretarias municipais e cargos eletivos. Nesta análise, será utilizado somente o último: para atribuir uma localidade a um candidato ao legislativo federal será verificado se o candidato a deputado federal já disputou algum cargo político local como prefeitura, vice-prefeitura ou vereança no passado e, em caso afirmativo, em qual município/região isso aconteceu. Para avaliar essa característica, buscou-se o passado político local dos candidatos de cada um dos pleitos. O primeiro pleito analisado (2002) teve apenas um pleito local como referência de busca, isto é, as eleições municipais de 2000. Já o último, de 2014, contemplou todas as eleições nacionais anteriores à este ano, até 2000. A tabela 7 mostra o número de candidatos analisados de acordo com seu passado político local.

Tabela 7 - Candidatos a deputado federal dos partidos analisados com Passado Político Local

\begin{tabular}{|c|c|c|c|c|c|c|c|c|c|c|c|c|}
\hline \multirow[b]{3}{*}{ Ano } & \multicolumn{12}{|c|}{ Eleições Municipais } \\
\hline & \multicolumn{3}{|c|}{2000} & \multicolumn{3}{|c|}{2004} & \multicolumn{3}{|c|}{2008} & \multicolumn{3}{|c|}{2012} \\
\hline & $\begin{array}{c}\text { Prefeito } \\
\text { e vice }\end{array}$ & Vereador & Total & $\begin{array}{c}\text { Prefeito e } \\
\text { vice }\end{array}$ & Vereador & Total & $\begin{array}{c}\text { Prefeito e } \\
\text { vice }\end{array}$ & Vereador & Total & $\begin{array}{l}\text { Prefeito e } \\
\text { vice }\end{array}$ & Vereador & Total \\
\hline 2002 & 21 & 64 & 81 & - & - & - & - & - & - & - & - & - \\
\hline 2006 & 32 & 55 & 87 & 27 & 74 & 101 & - & - & - & - & - & - \\
\hline 2010 & 31 & 54 & 85 & 38 & 69 & 107 & 28 & 69 & 77 & - & - & - \\
\hline 2014 & 16 & 43 & 59 & 31 & 48 & 79 & 26 & 66 & 92 & 21 & 77 & 98 \\
\hline
\end{tabular}

Fonte: TSE. Elaboração Própria.

O número de candidatos com passado político local a cada pleito é alto, e estável ao longo dos pleitos. Naturalmente, há mais ex-vereadores na análise porque o número de vereadores é maior que o número de prefeitos e vice-prefeitos. A alocação destes candidatos por partido por região de passado político local se encontra no anexo 4. 


\subsection{3 - O candidato político local e a alocação regional}

Uma vez definidos os dois critérios de alocação regional de candidatos, filiação partidária e passado político local, o passo seguinte foi mesclar ambas as informações. Dado que a unidade de análise empregada para este trabalho é a região e não os municípios, o critério adotado foi que quando local de filiação e histórico de passado político local eram de uma mesma região, ainda que de municípios diferentes, então aquela região foi atribuída ao candidato. Quando cada um dos critérios de alocação apontava para regiões diferentes, o candidato foi excluído da análise, porque não era possível dizer, com segurança, qual era a sua região de pertencimento. Quando apenas uma das informações estava disponível (candidato filiado sem passado político local, ou candidato com passado político local, mas local de filiação em outro estado, por exemplo), então ela foi considerada a região de pertencimento do candidato. Dessa forma, apenas aqueles candidatos aos quais foi possível atribuir, com certeza, uma região foram analisados neste trabalho.

Isto posto, cabe analisar qual a capacidade de alocação de deputados federais de cada região. A magnitude dos distritos brasileiros é atribuída proporcionalmente à população, onde aos menores estados é conferida uma magnitude mínima de $\mathrm{M}=8$, e ao maior, São Paulo, $M=70$. Estes 70 deputados federais que representam o estado, teoricamente, podem ser alocados nas regiões. Assim sendo, é possível estimar quantos candidatos cada uma das 15 regiões definidas pela Regic do IBGE consegue eleger apenas com o seu próprio eleitorado.

Nesse sentido, a lógica da alocação de candidatos ao partido interessa não frente à população das regiões (como a magnitude), mas frente ao número de eleitores que, numa mesma região, poderá eleger seu (ou seus) candidato(s), a depender do número de pessoas suficientes para tal atingir um mínimo de votos que será convertido em cadeiras. A conversão de votos em cadeiras é feita por meio do cálculo do quociente eleitoral (QE) pelo método D'Hondt. Isso é, o quociente eleitoral $Q E$ do distrito d é dado por

$$
Q E_{d}=\frac{V v_{d}}{M_{d}}
$$


Em que $V v$ são os votos válidos do distrito $d$ e $M$ é a o número de cadeiras disponível nesse distrito $d$, ou seja, a sua magnitude. De maneira inversa, o cálculo da magnitude de cada uma das regiões $\mathrm{Mreg}_{r}$ dado o eleitorado regional pode ser descrito como

$$
\operatorname{Mreg}_{r}=\frac{V v_{r}}{Q E_{d}}
$$

Em que $V v_{r d}$ é quantidade de votos válidos na região $\mathrm{r}$ e $\mathrm{QE}_{\mathrm{d}}$ é o quociente eleitoral do distrito $d$. A tabela 7, abaixo, mostra os valores da magnitude eleitoral das regiões de São Paulo $\mathrm{Mreg}_{r}$, considerando o eleitorado de cada região.

Tabela 8 - Magnitude eleitoral das Regiões de SP dado seu eleitorado

\begin{tabular}{|c|c|c|c|c|c|c|c|c|}
\hline \multirow{2}{*}{ Região } & \multicolumn{2}{|c|}{2002} & \multicolumn{2}{|c|}{2006} & \multicolumn{2}{|c|}{2010} & \multicolumn{2}{|c|}{2014} \\
\hline & Eleitorado & Mreg $_{r}$ & Eleitorado & Mreg $_{r}$ & Eleitorado & Mreg $_{r}$ & Eleitorado & Mreg $_{r}$ \\
\hline Araraquara & 357.051 & 1,0 & 392.818 & 1,0 & 421.785 & 1,0 & 444.157 & 1,0 \\
\hline Bauru & 672.970 & 1,8 & 734.279 & 1,8 & 780.563 & 1,8 & 822.022 & 1,8 \\
\hline Botucatu & 313.296 & 0,9 & 346.747 & 0,9 & 372.918 & 0,9 & 394.108 & 0,9 \\
\hline Campinas & 3.161 .764 & 8,6 & 3.513 .383 & 8,8 & 3.854 .228 & 8,9 & 4.120 .533 & 9,0 \\
\hline Jundiaí & 461.888 & 1,3 & 519.498 & 1,3 & 567.301 & 1,3 & 607.419 & 1,3 \\
\hline Marília & 469.166 & 1,3 & 501.576 & 1,3 & 527.120 & 1,2 & 549.801 & 1,2 \\
\hline Ourinhos & 140.627 & 0,4 & 151.525 & 0,4 & 160.901 & 0,4 & 168.269 & 0,4 \\
\hline Presidente Prudente & 603.762 & 1,6 & 638.964 & 1,6 & 665.346 & 1,5 & 696.710 & 1,5 \\
\hline Ribeirão Preto & 1.409 .725 & 3,8 & 1.537 .014 & 3,8 & 1.659 .103 & 3,8 & 1.750 .954 & 3,8 \\
\hline RMSP & 12.331 .946 & 33,6 & 13.360 .606 & 33,4 & 14.397.239 & 33,3 & 15.136 .495 & 33,1 \\
\hline Santos & 1.230 .831 & 3,4 & 1.325 .485 & 3,3 & 1.437 .187 & 3,3 & 1.527 .732 & 3,3 \\
\hline São Carlos & 225.258 & 0,6 & 250.653 & 0,6 & 273.245 & 0,6 & 290.261 & 0,6 \\
\hline São José do Rio Preto & 1.510 .311 & 4,1 & 1.612 .731 & 4,0 & 1.717 .627 & 4,0 & 1.812 .957 & 4,0 \\
\hline São José dos Campos & 1.395 .461 & 3,8 & 1.563 .003 & 3,9 & 1.707 .034 & 3,9 & 1.825 .206 & 4,0 \\
\hline Sorocaba & 1.389 .931 & 3,8 & 1.559 .701 & 3,9 & 1.715 .168 & 4,0 & 1.851 .808 & 4,1 \\
\hline Total SP & 25.673.987 & 70 & 28.007 .983 & 70 & 30.256 .765 & 70 & 31.998 .432 & 70 \\
\hline
\end{tabular}

Considerando a distribuição do eleitorado e a magnitude $M=70$ de São Paulo, cada uma das regiões tem definido um valor que representa, em teoria, o número potencial de deputados eleitos para cada uma dessas regiões. Em outras palavras, a Região Metropolitana de São Paulo (RMSP), por exemplo, elegeria em média 33,4 deputados dos 70 totais eleitos no estado se a distribuição de eleitos fosse proporcional à distribuição de eleitores. Isso significa que a RMSP concentra cerca de $47 \%$ do eleitorado paulista e, por isso, em teoria teria $47 \%$ da representação estadual na Câmara dos Deputados. Analogamente, a região de Araraquara concentra 1,2\% do eleitorado do 
estado, e teria $1,2 \%$ da representação dos deputados do estado. O mapa 2 mostra isso graficamente:

Mapa 2 - Mapa da magnitude eleitoral das Regiões de SP dado seu eleitorado

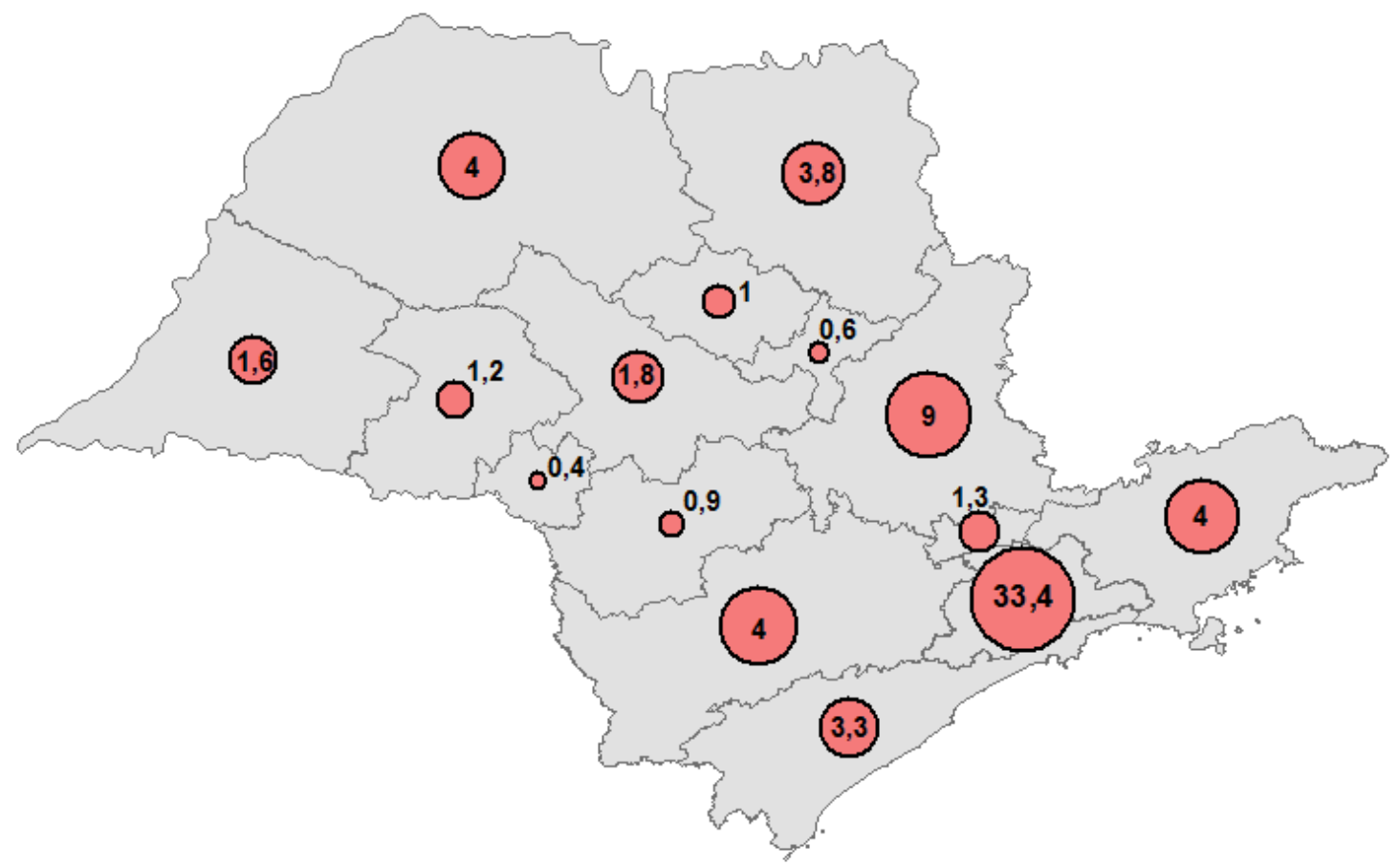

Fontes: Regic-IBGE; Base-shp: CEM/Cebrap. Elaboração Própria.

O mapa 2 ilustra a divisão de deputados possíveis por regiões da Regic - IBGE no estado de São Paulo dados sua magnitude $\mathrm{M}=70$ e seu eleitorado. Teoricamente, a magnitude de cada uma das regiões indica o número potencial de cadeiras que um partido pode pleitear no interior de cada uma delas, regiões com maior eleitorado têm valores maiores.

Nesse sentido, ceterus paribus, é racional que um partido lance, em cada uma das regiões, um número de candidatos igual ou menor à magnitude regional Mreg $_{r}$. Esse cenário, entretanto, só deve ser considerado isoladamente, isto é, se um só partido almejasse a meta irreal de eleger todos os 70 deputados federais do estado. Como isso é altamente improvável, cabe a cada uma das agremiações lançar um número menor de candidatos competitivos em cada pleito, maximizando suas chances de vencer frente aos recursos (partidário e financeiro) necessários para tal. Competitivos, em destaque, porque lançar candidatos não competitivos implica em mais votos agregados na soma do quociente eleitoral, e ao mesmo tempo em poucos custos aos partidos uma vez que 
estes candidatos não demandam tanto recursos quando os competitivos, aqueles que os partidos investem (capital político, partidário e financeiro) para eleger. Em outras palavras, é mais barato lançar candidatos não competitivos porque eles custam pouco ao partido. Cabe compreender, assim, como esses partidos alocam seus candidatos regionalmente. 


\section{4 - Como partidos alocam seus candidatos regionalmente?}

Se, conforme a teoria da geografia eleitoral, partidos agem como atores estratégicos maximizadores e fazem uso da dinâmica socioespacial, que origina fluxos de informação dentro das regiões, o que espera-se encontrar é uma distribuição otimizada de candidatos de acordo com o potencial eleitoral de cada uma das regiões. Ou seja, um número de candidatos próximo àquele que revela a capacidade de alocação de deputados federais por região.

Duas foram as formas de observar como os partidos alocam seus candidatos regionalmente. A primeira foi observar quantos candidatos estão presentes em cada uma das regiões. Neste primeiro caso, todos os candidatos foram considerados na análise, independente do número de votos que recebeu nas eleições. Dado o primeiro argumento (ver capítulo 1) de que partidos não exercem papel de controle da arena eleitoral, em tese, não se sabe quais candidatos têm maiores chances de sucesso eleitoral. Logo, primeiramente, todos os candidatos foram considerados igualmente competitivos.

Os mapas abaixo estão divididos por partido e por ano. Cada um dos tons de cores representa um ano eleitoral diferente e sua gradação representa o número de candidatos que um partido lançou neste ano, por região. Assim, quão mais escura a cor, mais candidatos foram lançados e, quanto mais claro, menos. Branco representa nenhum candidato lançado.

A despeito do tamanho da sua lista de candidatos, o mapa 3 evidencia o baixo número de candidatos que o PFL/DEM lançou em cada uma das regiões entre 2002 e 2010. Com exceção da região de Araraquara, cuja magnitude regional é de $\operatorname{Mreg}_{r}=1$ (ver mapa 2 acima) e o partido lançou dois candidatos, todos os demais distritos revelam que o partido alocou menos candidatos que o possível de acordo com as magnitudes regionais. 
Mapa 3 - Alocação regional de candidatos do PFL/DEM entre 2002 e 2010

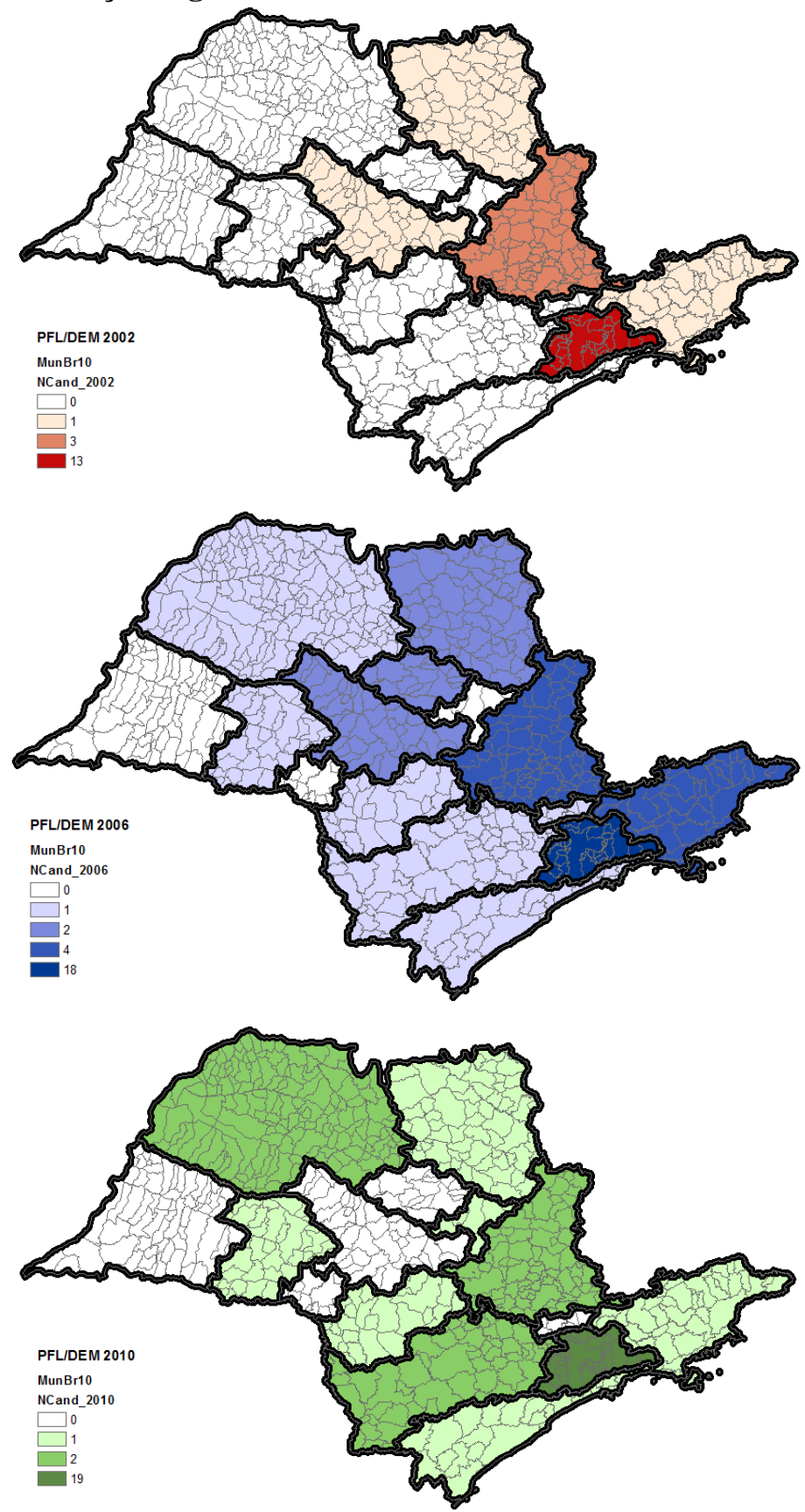

Fontes: Regic-IBGE; Base-shp: CEM/Cebrap. Elaboração Própria.

O PMDB, por sua vez, apresenta no geral um número de candidatos por região abaixo da magnitude regional na maioria das regiões. 
Mapa 4 - Alocação regional de candidatos do PMDB entre 2002 e 2014
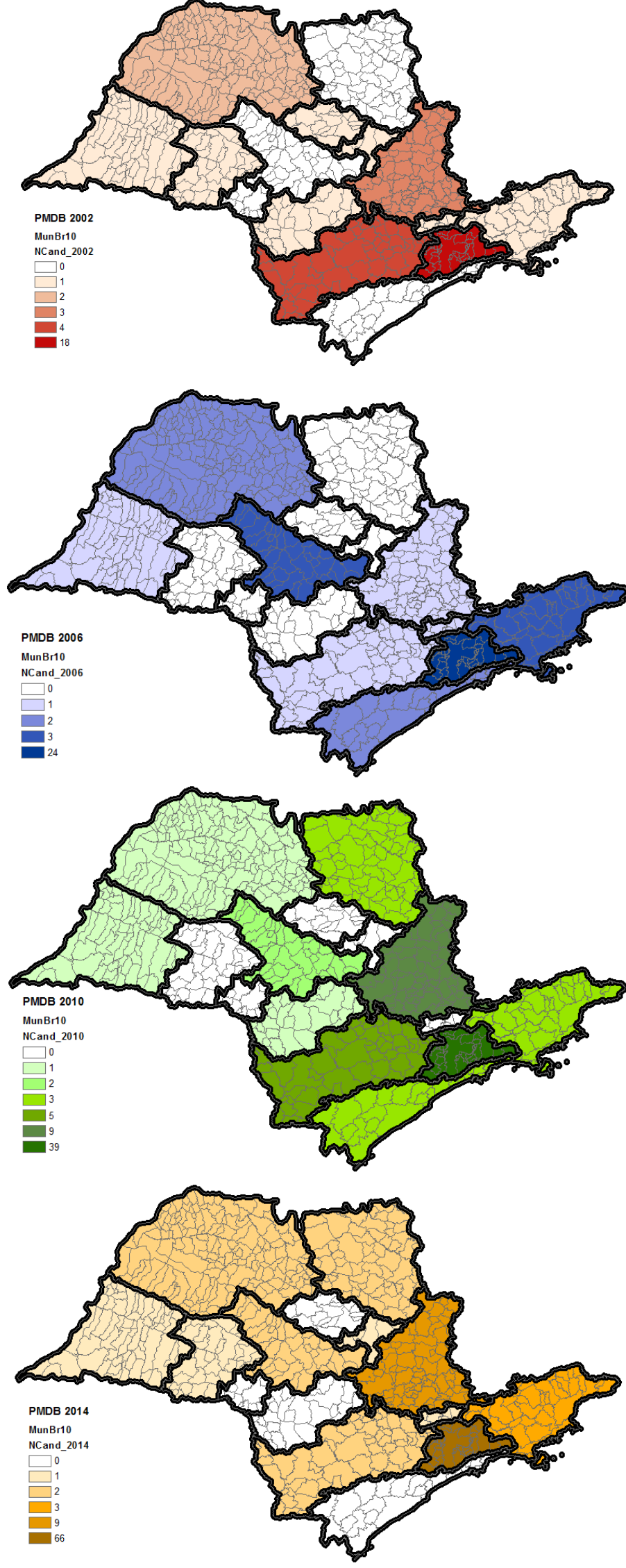

Fontes: Regic-IBGE; Base-shp: CEM/Cebrap. Elaboração Própria. 
Conforme mostra o mapa 4, exceções são apenas em 2006 e 2010 para a região de Bauru, em que o partido apresenta 3 candidatos, mas a $\operatorname{Mreg}_{r}=1,8$; em 2010, que o partido apresenta para a região de Sorocaba 1 candidato a mais do que a magnitude regional $\left(\right.$ Mreg $\left._{r}=4\right)$; e na RMSP que, em 2010 o partido apresenta cerca de 5 candidatos a mais que o limite da região $\left(\operatorname{Mreg}_{r}=33,4\right)$, e em 2014, em que apresenta aproximadamente o dobro da capacidade regional de candidatos.

Vale destacar que, conforme a geografia eleitoral, a RMSP tem um diferencial frente às demais regiões. O município de São Paulo é conceituado como "Grande metrópole regional", 1A, e por isso consegue influenciar o fluxo informacional de outras regiões com alguma facilidade. Esse argumento não o descaracteriza enquanto polo de uma região - a RMSP -, mas aponta que informações de São Paulo (município) extravasam seu limiar regional com mais facilidade porque é hierarquicamente superior, característica que lhe confere a possibilidade de "chegar" a regiões mais distantes mais facilmente que polos hierarquicamente inferiores. Concretamente, cidadãos das demais regiões vão mais à cidade de São Paulo porque esta é a capital de seu estado e serviços que são oferecidos nela frequentemente não são em outros polos regionais de hierarquia mais baixa (ou, ao menos, não com tamanha oferta que é encontrada em São Paulo). Ou ainda, jornais produzidos em São Paulo são vendidos em outras regiões do estado, enquanto jornais de outros municípios são circunscritos às suas regiões ${ }^{39}$.

Não se pretende, com este argumento, oferecer uma justificativa ao fato do PMDB lançar o dobro de candidatos que a região consegue alocar. $\mathrm{O}$ intuito é afirmar que em certa medida é natural - conforme o argumento - que a RMSP tenha mais candidatos do que pode alocar em si já que estes conseguem extravasar o seu limite regional com mais facilidade que candidatos de regiões cujo município polo é hierarquicamente inferior à São Paulo (1A). Essa estratégia (de alocar mais candidatos na RMSP que sua capacidade regional), entretanto, é utilizada pelos partidos, como evidenciam os mapas 5 e 6, do PPB/PP e PT, respectivamente. Conforme o mapa 5, o PPB/PP somente 2010 ultrapassa o limite regional de 33,4 candidatos na RMSP. Em todos os demais anos o partido apresenta um número de candidatos alinhado com o a magnitude regional teórica.

\footnotetext{
${ }^{39}$ Para mais detalhes sobre o fluxo de jornais e pessoas no estado de São Paulo (cuja proxy é o transporte rodoviário diário), ver anexo 5.
} 
Mapa 5 - Alocação regional de candidatos do PPB/PP entre 2002 e 2014
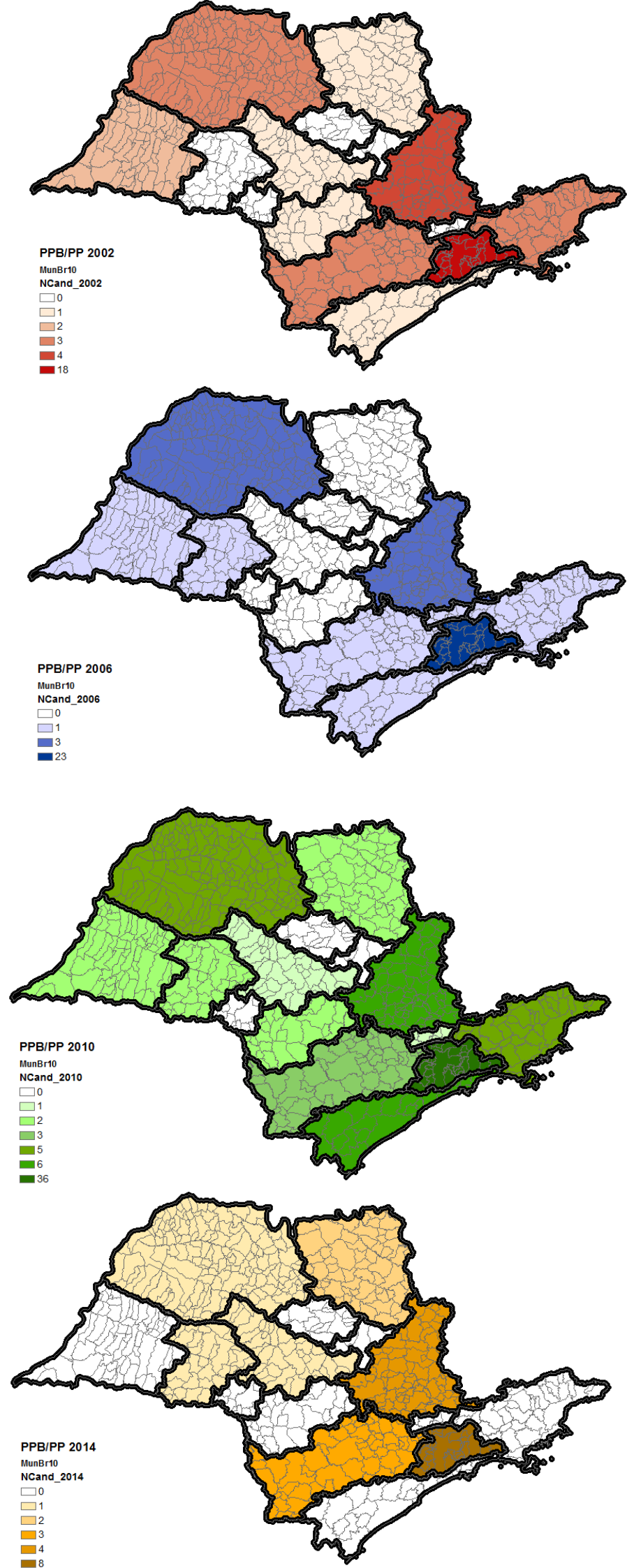

Fontes: Regic-IBGE; Base-shp: CEM/Cebrap. Elaboração Própria. 
O limite teórico de $\mathrm{Mreg}_{r}=9$ da região de Campinas é ultrapassado pelo PT em 2002, em 5 candidatos (lança 14) e em 2010, em 1 candidato. Essa extrapolação acontece ainda em 2010 e 2014 para a RMSP em, respectivamente 2 e 8 candidatos, e em Ourinhos, em 2014 (apenas 1 candidato a mais).

Mapa 6 - Alocação regional de candidatos do PT entre 2002 e 2014
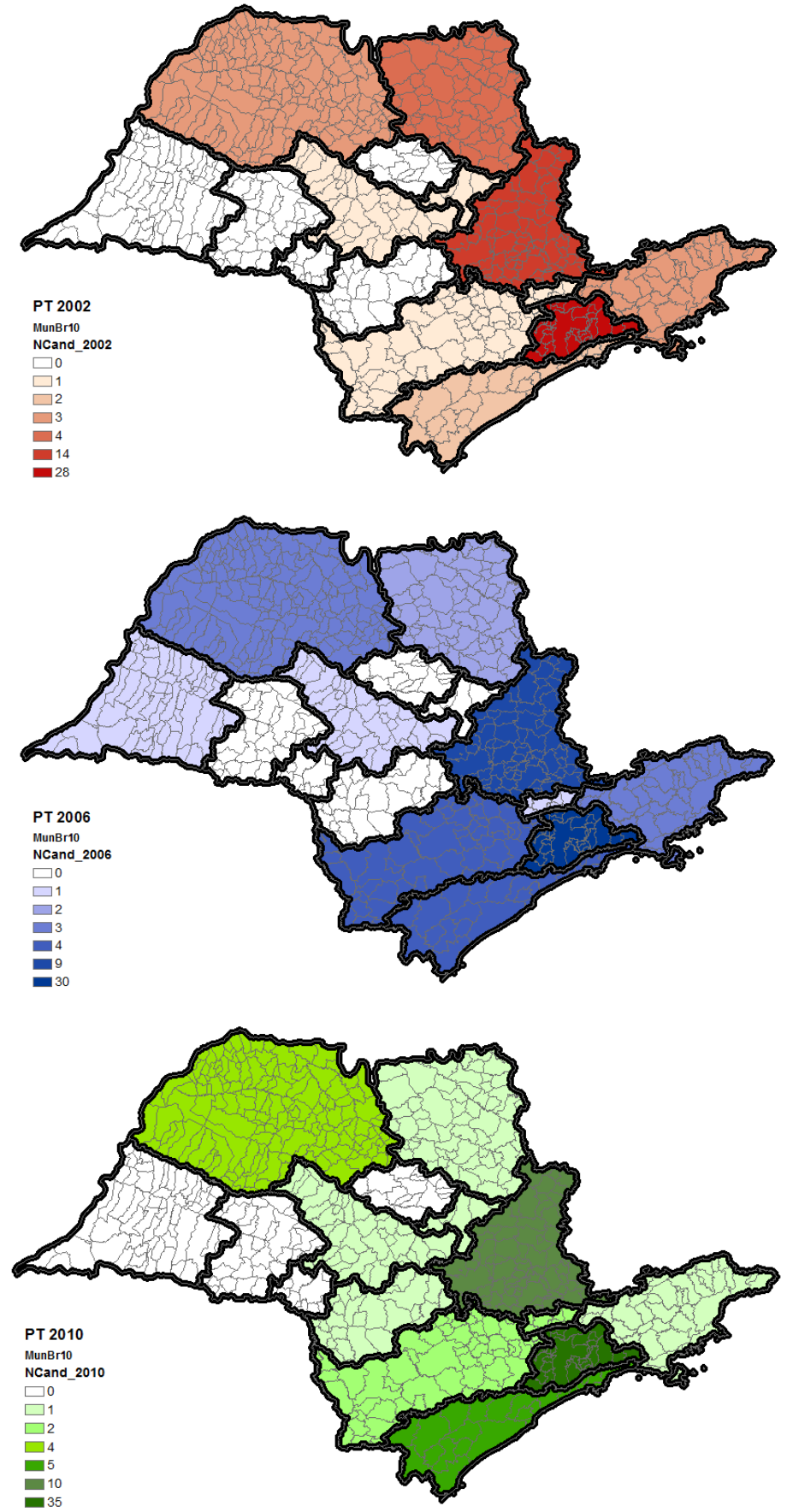


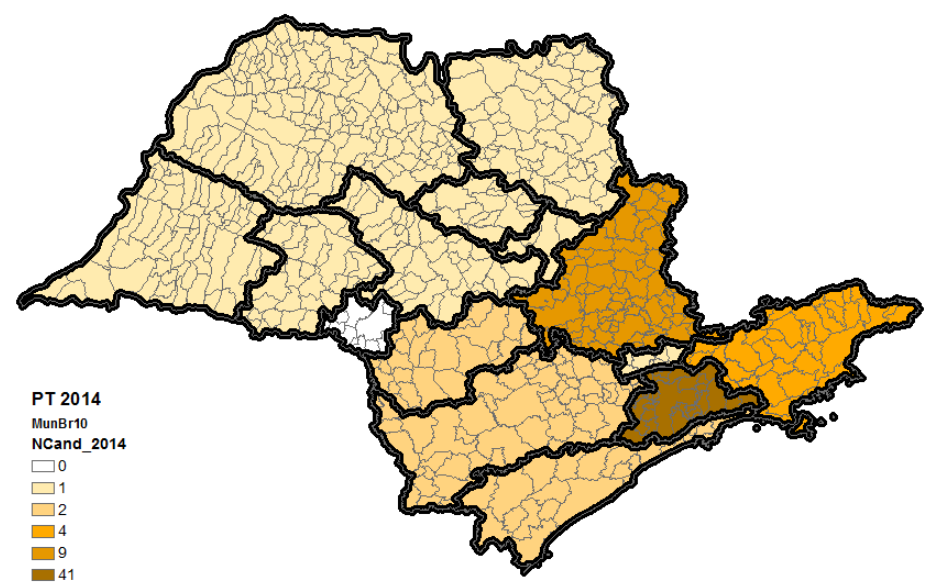

Fontes: Regic-IBGE; Base-shp: CEM/Cebrap. Elaboração Própria.

O PSD só participou da eleição de 2014, quando competiu pela primeira vez e tirou o posto do PFL/DEM de quinto mais votado no Brasil. Conforme evidencia o mapa 7, apresenta poucos candidatos por região, não excedendo a magnitude regional criada em nenhuma delas.

Mapa 7 - Alocação regional de candidatos do PSD em 2014

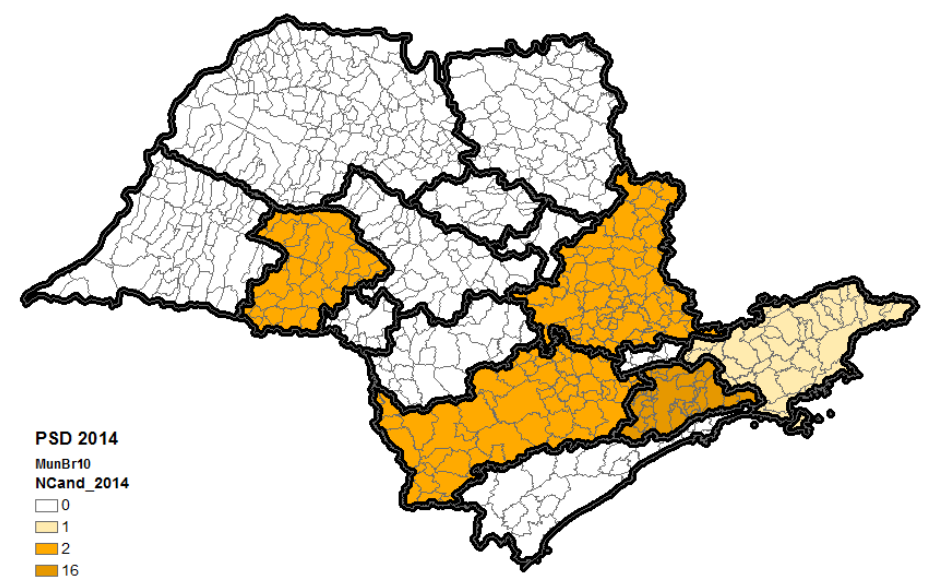

Fontes: Regic-IBGE; Base-shp: CEM/Cebrap. Elaboração Própria.

O mapa 8 mostra os dados de alocação regional do PSDB entre 2002 e 2014. O partido, como mostra o mapa, lança poucos candidatos a mais que a magnitude regional quando o faz. 
Mapa 8 - Alocação regional de candidatos do PSDB entre 2002 e 2014
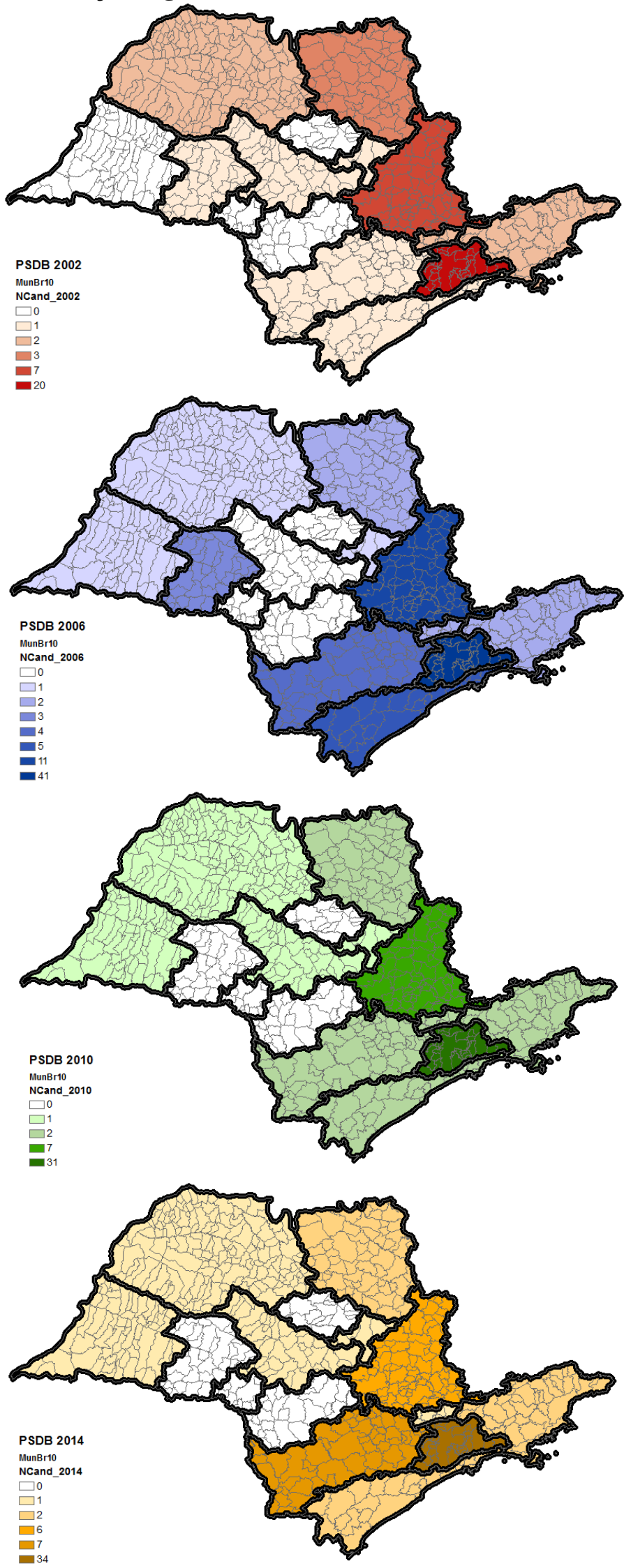

Fontes: Regic-IBGE; Base-shp: CEM/Cebrap. Elaboração Própria. 
Em 2002 o partido não lançou nenhum candidato a mais que a magnitude regional. Em 2006, entretanto, lançou 41 candidatos na RMSP, em que a $M r e g_{r}=33,4$. Lança, ainda, 11 candidatos na região de Campinas, 2 a mais que a sua magnitude regional. Também em Santos o partido lança 5 candidatos, dois a mais que a magnitude da região $\left(\mathrm{Mreg}_{r}\right.$ = 3,3). Em 2014, lança, por fim, 7 candidatos na região de Sorocaba, em que a Mreg $_{r}=$ 4.

A análise da alocação regional de todos os candidatos lançados pelos partidos entre 2002 e 2014 mostra que, no geral, são poucas as regiões em que partidos lançam mais candidatos que a magnitude regional atribuída às regiões de acordo com o seu eleitorado e a magnitude do distrito de SP. O lançamento de mais candidatos que a magnitude regional ocorre com mais frequência na RMSP, o que pode, em parte, ser explicado pelo nível hierárquico da cidade polo desta região, a grande metrópole nacional, conforme a classificação da Regic - IBGE.

Esse fenômeno do baixo número de candidatos por região implica que, se considerada razoável a magnitude de cada uma das regiões de São Paulo, na maior parte delas não há, em tese, competição intrapartidária. Mesmo nos casos em que o número de candidatos é mais alto que a $\operatorname{Mreg}_{r}$ a competição é relativamente baixa, com exceção da RMSP - que tem uma dinâmica própria. Latner e McGann (2005) também ressaltam a importância das capitais para os partidos Nos casos analisados pelos autores, Israel e Holanda, também há um viés que beneficia o lançamento de candidaturas nessas cidades, como explicitado no capítulo 1, levando a um maior número de candidatos por partidos nessas regiões.

No geral, o número de candidaturas por região se encaixa num padrão de número possível de candidatos conforme o critério geoespacial. Ora, se partidos não alocassem estrategicamente seus candidatos com vistas a contornar sua competição interna gerada pela magnitude elevada e a lista aberta, a explicação para a distribuição regional de candidatos como os mapas acima mostram seria fruto de uma vicissitude? Vale ressaltar que a análise acima foi desenvolvida com base em todos os candidatos.

Se considerado de Cheibub e Sin (2015), desenvolvido no capítulo 1, de que partidos ponderam as candidaturas que lançam pelo perfil dos candidatos, como se apresenta o padrão partidário de lançamento de candidaturas? A diferenciação das candidaturas entre fracos, fortes e invencíveis - é relevante à organização partidária. Carneiro (2009) 
mostra por meio de entrevistas com as lideranças partidárias dos maiores partidos ${ }^{40}$ entre 1994 e 2006, que há uma classificação interna dos candidatos, a saber,

\begin{abstract}
"aquele que se sabe que tem muito voto, o chamado 'puxador de voto'; aquele que vai se eleger, mas o número de votos não é alto, não chega a ser um puxador, é o que chamamos de 'pipão'; aquele que tem voto médio, vai ajudar muito a legenda, dá consistência, mesmo não sendo eleito, é o que chamamos de 'rabiola da pipa'; e, por último, tem o que chamamos de 'rabo', são aqueles que simplesmente compõem a legenda, estão ali para 'tapar buraco', não vão ter quase voto nenhum. Em alguns casos ainda tem 'o rabo do rabo', esses ainda têm menos votos" (Laura Carneiro, vice-presidente de assuntos do diretório municipal do DEM - entrevista realizada em 06/03/2008) (Carneiro, 2009, p.112).
\end{abstract}

As entrevistas de Carneiro revelam ainda que partidos, ao escolher os candidatos que irão compor suas listas, evitam escolher nomes que podem dividir os votos entre candidatos fortes em certas regiões. Essa foi a aposta de Nicolau (2006) que aponta o fenômeno; mais tarde também de Braga e Amaral (2013).

Assim sendo, faz-se necessário observar como se dá a distribuição de candidaturas quando se considera apenas aqueles que são, em alguma medida, competitivos para o partido. Classificar as chances de sucesso eleitoral de um candidato é tarefa arbitrária uma vez que é impossível saber quais são, aos olhos do partido, os critérios ou o corte que coloca de um lado os candidatos competitivos e aqueles que não o são. Com o intuito de diminuir tal arbitrariedade optou-se aqui por um critério singelo: a obtenção de cadeiras por um partido é condicionada ao cálculo do quociente eleitoral $Q E$, como já mencionado, assim a escolha foi usar um corte do $Q E$ para definir quais candidatos podiam ser considerados como competitivos. Esse corte do $Q E$ utilizado foi de $10 \%$ do quociente estadual do ano. Ou seja, apenas candidatos que atingiriam sozinhos $10 \%$ do $Q E^{41}$ foram considerados competitivos. A tabela 8 abaixo ilustra o critério adotado.

\footnotetext{
${ }^{40} \mathrm{PT}, \mathrm{PSDB}, \mathrm{PFL} / \mathrm{DEM}$ e PMDB.

${ }^{41}$ Conforme este critério, em 2002129 candidatos foram considerados competitivos, dentre eles, 65 eleitos. Em 2006, 145 eram competitivos, tendo sido 68 eleitos. Em 2010, de 141 competitivos, 70 foram eleitos. Já em 2014, 136 eram competitivos e, destes, 68 foram eleitos. O número de candidatos competitivos por partido por ano encontra-se no Anexo 6.
} 
Tabela 9- Quociente Eleitoral - SP $(M=70)$ e Corte do QE para Candidatos Competitivos

\begin{tabular}{cccccc}
\hline \hline Ano & Votos Nominais & Votos de Legenda & $\begin{array}{c}\text { Votos Válidos } \\
\text { (nominais + legenda) }\end{array}$ & $\begin{array}{c}\text { Quociente Eleitoral } \\
\text { (votos válidos/M) }\end{array}$ & $\begin{array}{c}\text { Corte } \\
\text { 10\% QE }\end{array}$ \\
\hline 2002 & 17.593 .894 & 2.023 .376 & 19.617 .270 & 280.247 & 28.025 \\
2006 & 18.015 .340 & 2.768 .680 & 20.784 .020 & 296.915 & 29.691 \\
2010 & 19.370 .010 & 2.673 .624 & 22.043 .634 & 314.909 & 31.491 \\
2014 & 19.072 .417 & 2.193 .777 & 21.266 .194 & 303.803 & 30.380 \\
\hline
\end{tabular}

Fonte: TSE. Elaboração Própria.

Nesta acepção, para ser considerado competitivo um candidato precisaria obter em média 29.895 votos, ou $10 \%$ do QE. Vale ressaltar que apenas $30 \%$ dos municípios paulistas, de acordo com o Censo de 2010, têm mais que 29.000 habitantes. Assim, para ser considerado competitivo bastaria a um candidato conquistar $0,19 \%$ do eleitorado da RMSP, ou 0,34\% dos votos da cidade de São Paulo, ou ainda todos os votos do município de Ituverava (cujo eleitorado é de 30.305), na Região de Ribeirão Preto.

Considerando a importância da distinção dos candidatos para os partidos, conforme sugerem Carneiro (2009) e Cheibub e Sin (2015), os mapas a seguir ilustram a distribuição regional dos candidatos competitivos (que obtiveram um mínimo de $10 \%$ do $Q E$ ) alocados nas listas dos partidos analisados entre 2002 e 2014.

O mapa 9 mostra que PFL/DEM lança um número bastante baixo de candidatos competitivos em todo o estado de São Paulo entre 2002 e 2010. Dos seus 93 candidatos totais ao longo dos anos, apenas 36 podem ser considerados competitivos. Mais uma vez há uma concentração destes candidatos na RMSP, mas em nenhum dos pleitos ela ultrapassa $25 \%$ do total de candidatos que o partido, em tese, poderia lançar e ainda assim não ter competição intrapartidária (isto é, o teto de 33,4 candidatos para esta região). Dessa forma, seus 8 candidatos lançados na RMSP em 2010 competiam internamente falando - pelas 33 cadeiras daquela região. Sem considerar a competição interpartidos é como os candidatos do PFL/DEM tivessem, nessa região, 4 cadeiras em disputa para cada um deles. 
Mapa 9 - Alocação regional de candidatos competitivos do PFL/DEM entre 2002 e 2010
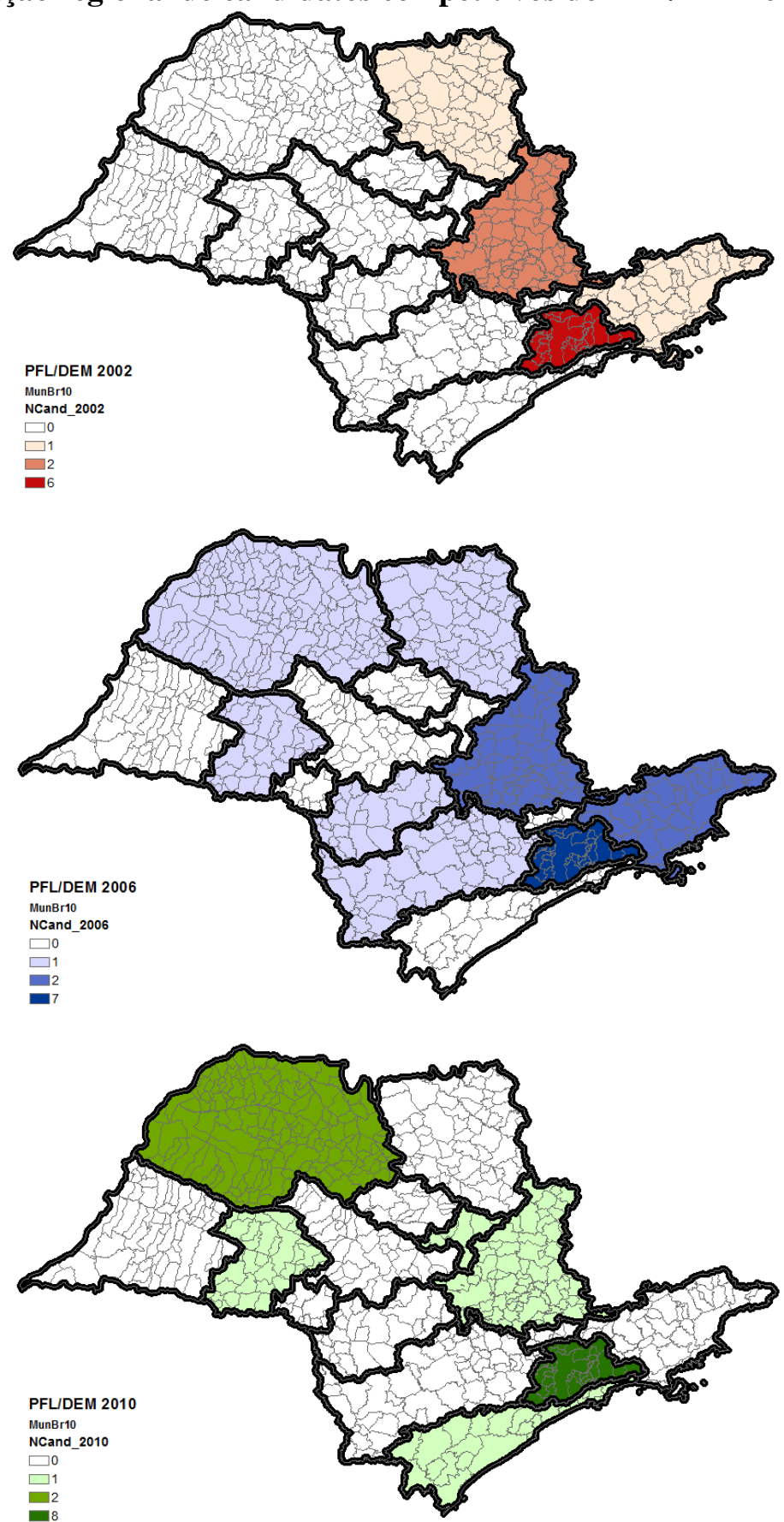

Fontes: Regic-IBGE; Base-shp: CEM/Cebrap. Elaboração Própria.

No PMDB, que lançava tantos candidatos - inclusive excedendo o limite da magnitude regional - o cenário é ainda mais destacado. O número máximo de candidatosc competitivos lançados numa região, a RMSP, é 6. Em todas as demais regiões o partido ou não está presente com candidatos competitivos, ou não lança candidatos, conforme o mapa 10: 
Mapa 10 - Alocação regional de candidatos competitivos do PMDB entre 2002 e 2014
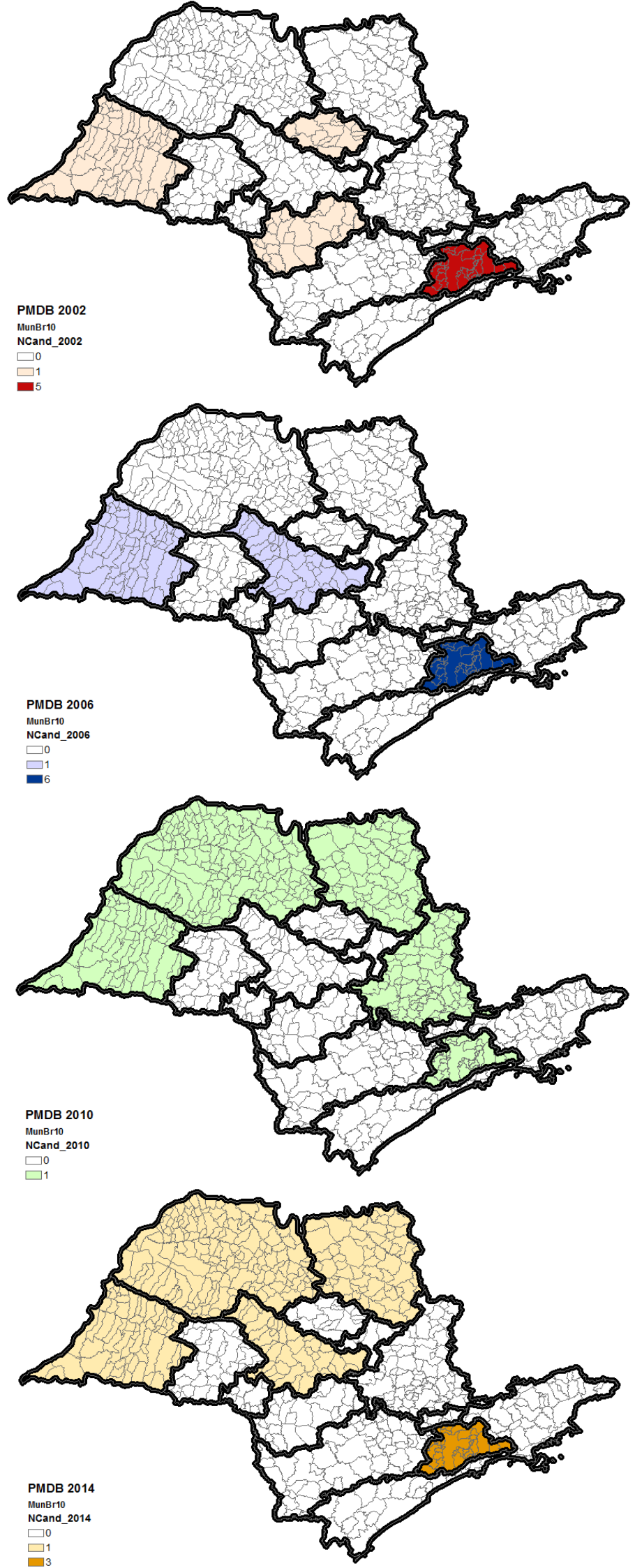

Fontes: Regic-IBGE; Base-shp: CEM/Cebrap. Elaboração Própria. 
Vale ressaltar que o PMDB tem apresentado um desempenho que cai a cada ano na disputa do legislativo federal em São Paulo. Ainda assim, é um dos maiores partidos nacionais e o partido com maior número de filiados em todo o estado, com mais de 600mil membros. Além disso, é o segundo partido com maior número de prefeituras no estado, estando a frente de 89 prefeituras desde 2012, 19 a mais que o pleito anterior, em 2008, quando conquistou 70 prefeituras. Curiosamente, se de um lado o partido não mostra, absolutamente, sinais de mingua, por outro, apresenta poucos candidatos competitivos à Câmara dos Deputados.

O PPB/PP, por sua vez, também tem um quadro pequeno de candidatos competitivos por região. Conforme o mapa 11, apresenta mais candidatos na RMSP - um padrão -, mas ainda assim o número de candidatos é baixo, em média, 2,75 candidatos nesta região.

Mapa 11 - Alocação regional de candidatos competitivos do PPB/PP entre 2002 e 2014
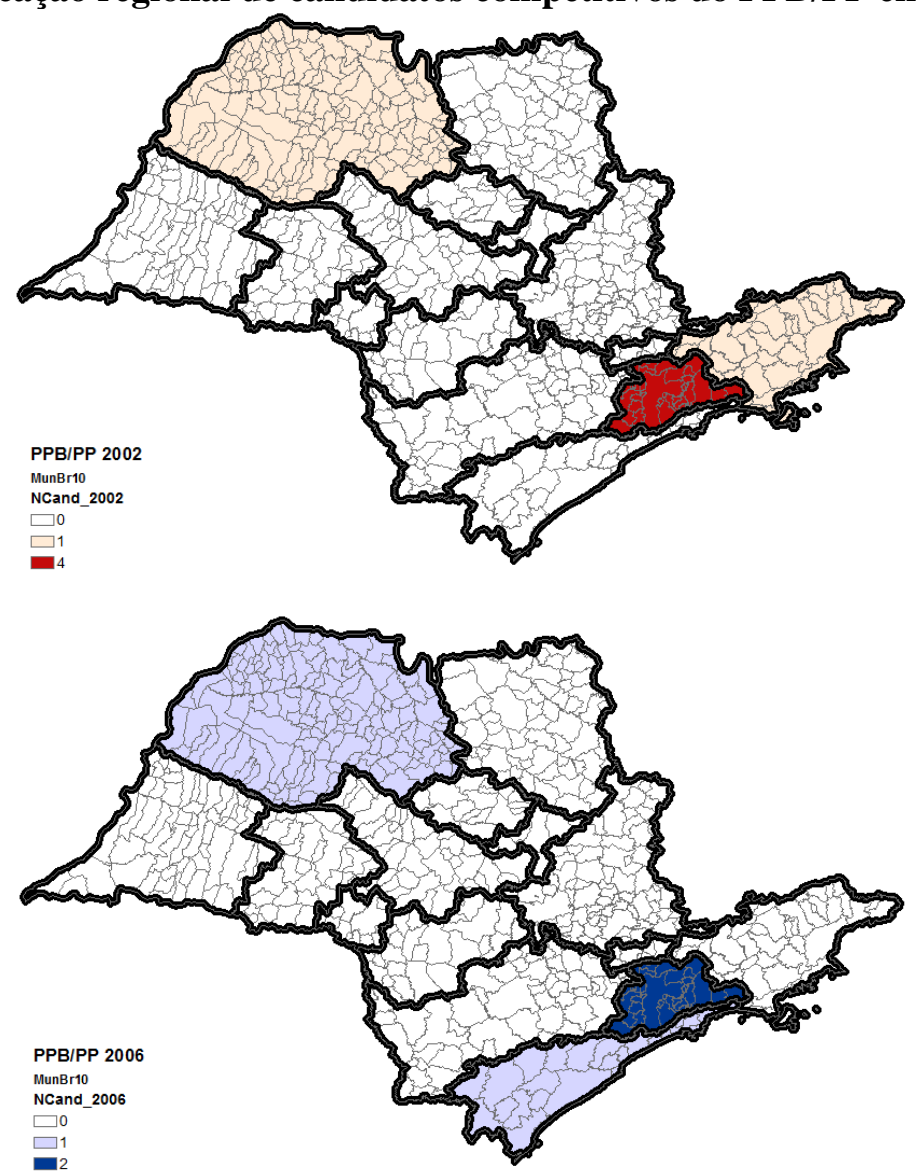

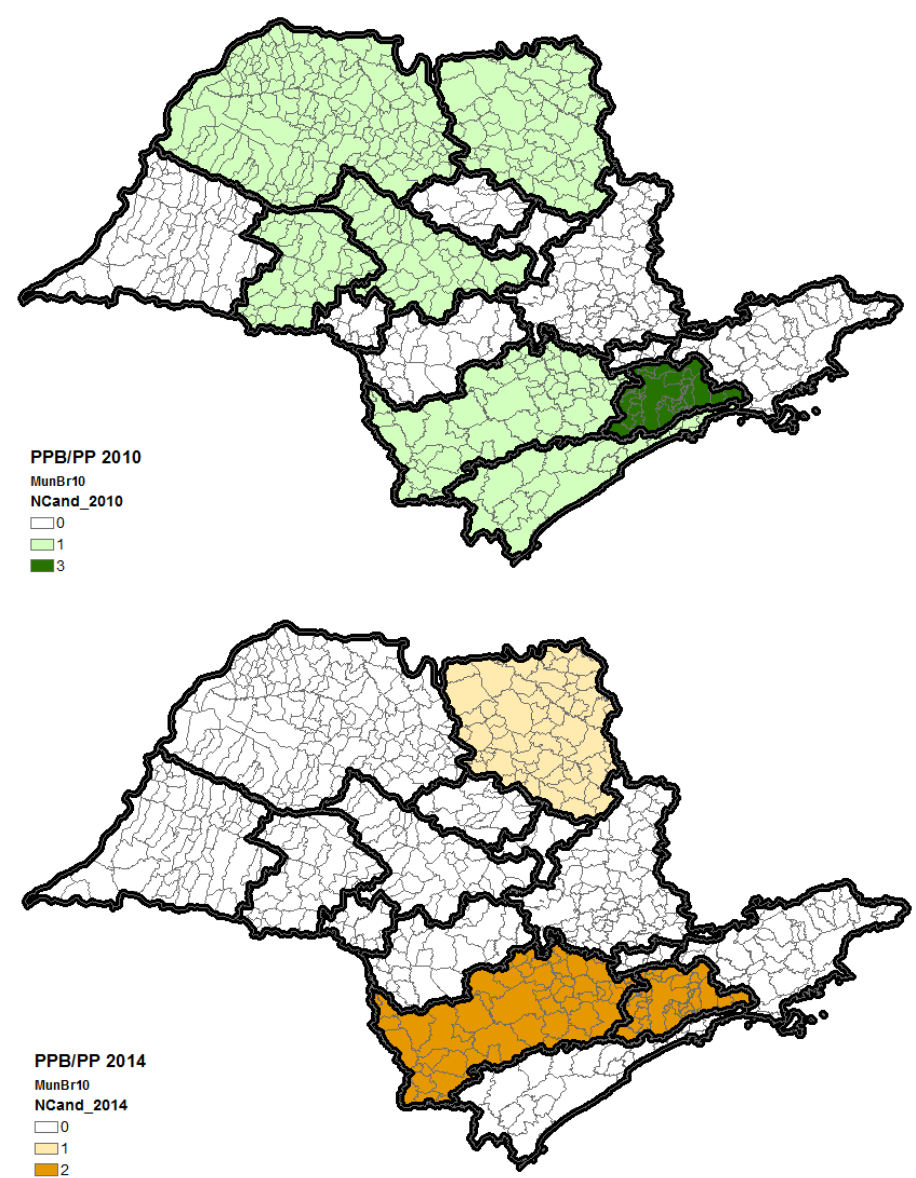

Fontes: Regic-IBGE; Base-shp: CEM/Cebrap. Elaboração Própria.

Já o PT apresenta mais candidatos competitivos que seus adversários anteriormente analisados. Ainda que esses candidatos competitivos se concentrem, majoritariamente, na RMSP - berço do partido -, o partido se faz presente também nas demais regiões do estado. Mais uma vez, em nenhuma das regiões a magnitude regional é ultrapassada, sendo que o maior número de candidatos é na RMSP $\left(\right.$ Mreg $\left._{r}=33,4\right)$ em 2014, onde apresenta 20 candidatos. 
Mapa 12 - Alocação regional de candidatos competitivos do PT entre 2002 e 2014
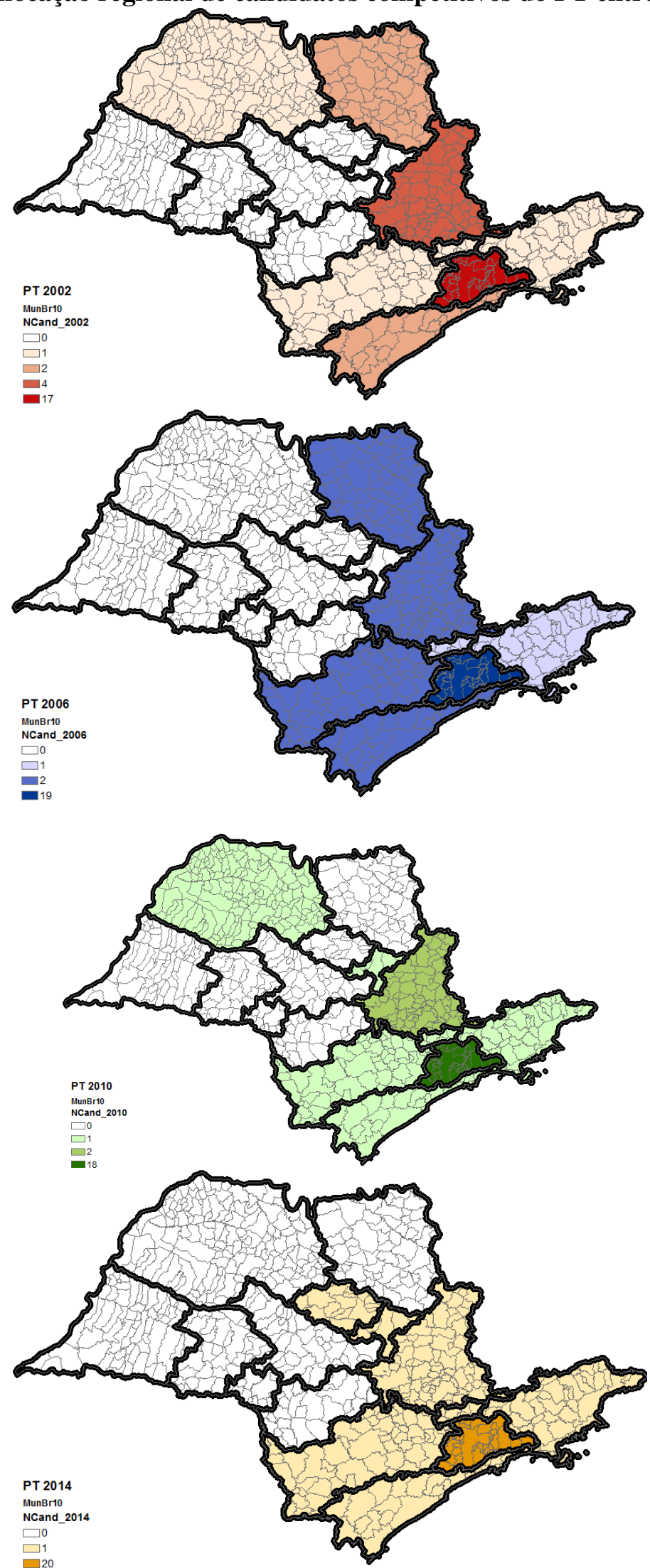

Fontes: Regic-IBGE; Base-shp: CEM/Cebrap. Elaboração Própria. 
O PSD, presente na análise apenas em 2014, mais uma vez tem uma lista modesta, em que apresenta apenas 6 candidatos competitivos na RMSP, e está presente em apenas outras 4 regiões do estado com um número ainda menor de candidatos competitivos em sua lista de candidatos.

Mapa 13 - Alocação regional de candidatos competitivos do PSD entre 2002 e 2014

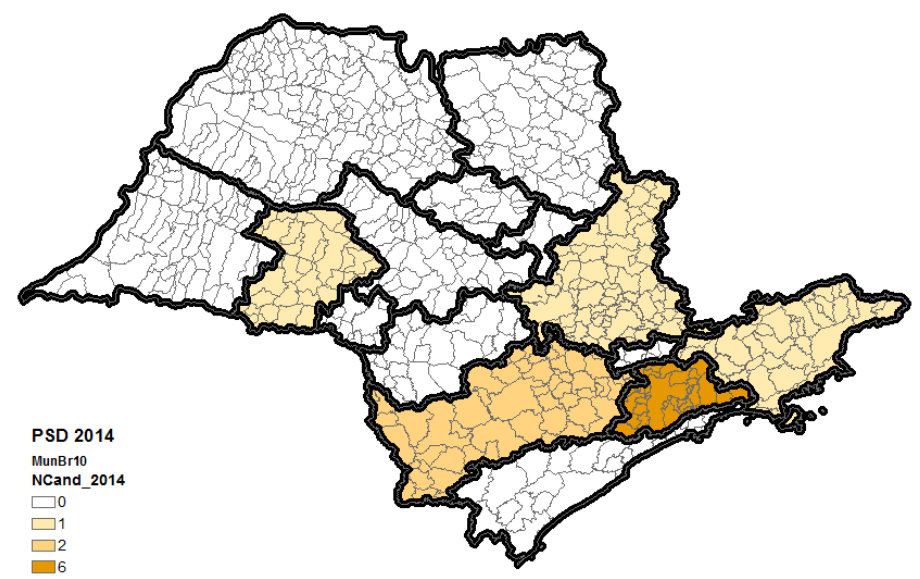

Fontes: Regic-IBGE; Base-shp: CEM/Cebrap. Elaboração Própria.

Por fim, o PSDB, como o PT, está mais presente em diferentes regiões que os demais partidos; apresenta também mais candidatos na RMSP do que nas outras regiões. Ainda assim, em nenhuma das regiões o partido apresenta mais candidatos que o limite da magnitude regional, atingindo o teto apenas na região de Sorocaba, em 2010, com 4 candidatos, o mesmo valor de magnitude regional deste local. 
Mapa 14 - Alocação regional de candidatos competitivos do PSDB entre 2002 e 2014

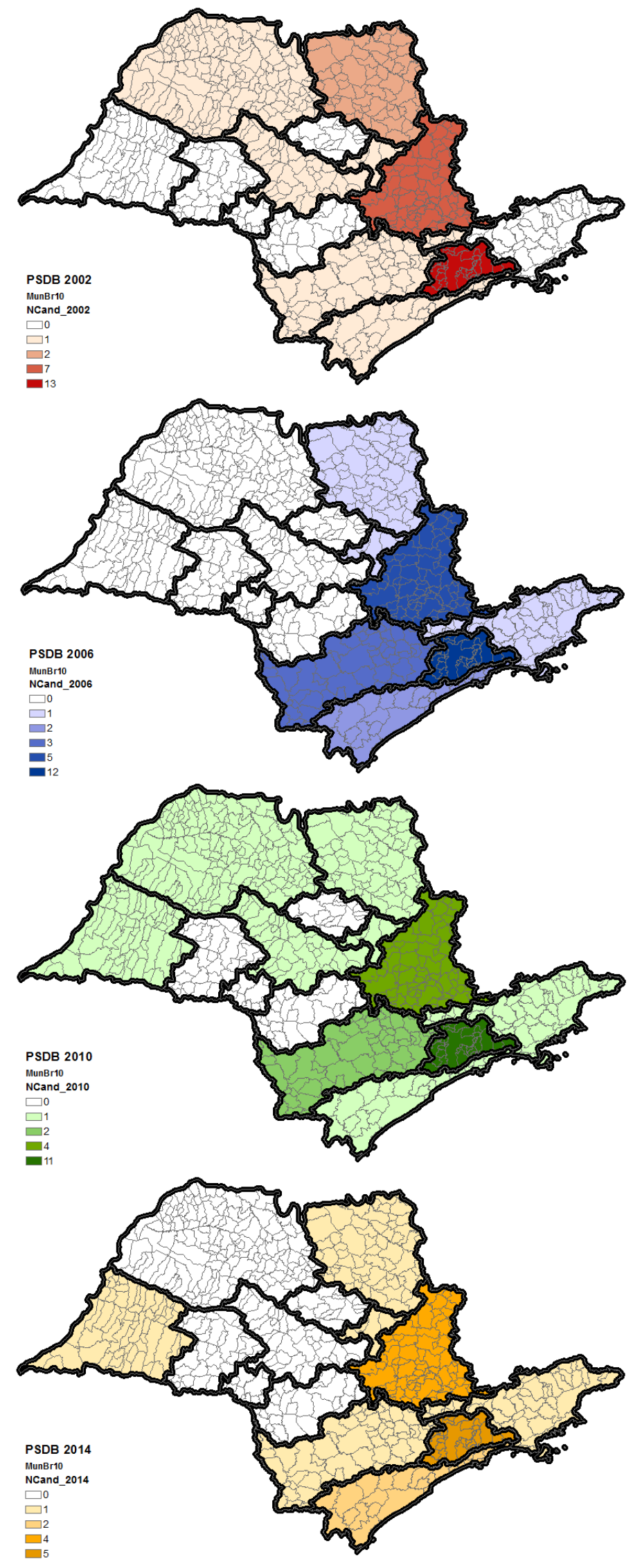

Fontes: Regic-IBGE; Base-shp: CEM/Cebrap. Elaboração Própria. 
A análise da alocação partidária regional dos candidatos considerados competitivos pelo critério de $10 \%$ do QE mostrou que a competição intrapartidária é mínima para qualquer um dos cinco maiores partidos que se analise. Estes partidos, como já fora ressaltado, são os maiores partidos nacionais (que mais elegem candidatos sistematicamente ao longo das eleições nacionais) e fazer parte da sua lista de candidatos aumenta, em teoria, a chance de vitória de um candidato. Todos eles têm alto número de filiados no estado, o que evidencia sua grande estrutura organizacional. Não se pode, portanto, creditar o baixo número de candidatos na lista destes partidos a uma falta de candidatos disponíveis que esses partidos teriam ao compor suas listas em cada eleição.

A alocação regional de candidatos - de acordo com as regiões estabelecidas pela Regic do IBGE - contorna eficazmente a competição intrapartidária que é causada como um efeito perverso pela lista aberta e pela elevada magnitude dos distritos eleitorais brasileiros. O caso do estado de São Paulo ilustra tal achado. Não se pretende, com isso, afirmar que partidos conhecem a estrutura desenhada pelo IBGE na Regic, mas que naturalmente alocam os candidatos de suas listas conforme as regiões formadas em torno das grandes cidades do estado, da mesma forma que o morador de Presidente Venceslau, a $628 \mathrm{~km}$ do município de São Paulo, e a $57 \mathrm{~km}$ de Presidente Prudente, sabe que quando precisa de assistência médica, ele deve buscar em Presidente Prudente, e não em Sorocaba, ou em Ribeirão Preto. Ou como o morador de São Vicente (a 8 km de Santos), que lê e se interessa mais por notícias dos jornais de Santos, do que dos jornais de São José do Rio Preto (a 526 km de São Vicente), ou São José dos Campos (a $156 \mathrm{~km})$. Em outras palavras, é a relação de proximidade engendrada pela estrutura sociogeográfica do estado que baliza a vida e o cotidiano de eleitores, candidatos e partidos. Partidos podem "burlar" tal estrutura, mas isso acarreta custos reais, como a construção de candidaturas em locais distantes tanto quanto capital humano-partidário, quanto a recursos financeiros propriamente falando.

Cabe questionar se essa lógica regional que pode ser verificada na formação da lista partidária se aplica também à lógica eleitoral em si. Isto é, se na dinâmica política eleitoral a lógica regional se faz igualmente presente frente aos olhos do eleitorado. 


\section{5 - Mas candidatos regionais são mais votados em suas regiões?}

Conforme o argumento da geografia eleitoral, a lógica das regiões tomadas concretamente pelas regiões da Regic do IBGE não agem somente sob o mundo das decisões partidárias, mas também age na perspectiva do eleitor. Posto de outra maneira, a dinâmica do mundo social dada pelo espaço é a base tanto das decisões partidárias quanto das decisões do eleitor. A análise das estratégias partidárias, como desenvolvida até aqui, preocupou-se somente com a esfera partidária. Certamente a estratégia é voltada para o sucesso eleitoral e a conquista de votos, isto é, mesmo que o candidato não vença as eleições isso não implica que seu partido não tenha agido de forma estratégica. Mas só fará sentido ao partido agir de tal forma se a dinâmica regional se refletir também na decisão do eleitor. Cabe questionar, como essa dinâmica geoespacial se reflete no voto?

Teoricamente a relação de proximidade engendrada pela geografia e as estruturas sociais que são influenciadas por ela fariam com que o eleitor concedesse seu voto ao candidato mais próximo geograficamente. $\mathrm{O}$ candidato da região, portanto, deveria estar à frente dos demais candidatos do partido: o eleitor santista, imerso na região de Santos e na dinâmica própria desta região, tenderia a votar no candidato local, aquele o qual o eleitor identifica como o candidato regional. Assim, o candidato Santista tenderia a ser o mais votado na região sul-litorânea do que o candidato de Campinas, por exemplo.

A exceção seria o candidato da RMSP. Como explicitado anteriormente, nesta região se localiza a "Grande Metrópole Nacional", a cidade de São Paulo. Hierarquicamente superior à todas as demais, São Paulo teria maior alcance sobre as demais regiões, de forma que o candidato local da RMSP consegue atingir outras regiões com mais facilidade que outros candidatos de outras regiões. Sendo assim, o argumento permite dois resultados possíveis: independente da posição final do candidato na lista do partido, numa determinada região vence ou o candidato local, ou o candidato da grande metrópole nacional, da RMSP.

O gráfico 1 abaixo evidencia a relação entre a posição do candidato na lista final do partido - isto é, se ele é o $1^{\circ}, 2^{\circ}$ ou n ${ }^{\circ}$ mais votado frente a todos os candidatos no estado - e a posição deste mesmo candidato no interior da sua região para o caso do PFL/DEM. Cada ponto representa um candidato da lista do partido, independente da sua região - somente os da RMSP estão destacados. 


\section{Gráfico 2 - Posição do candidato na lista geral do partido e na sua respectiva região - PFL/DEM}

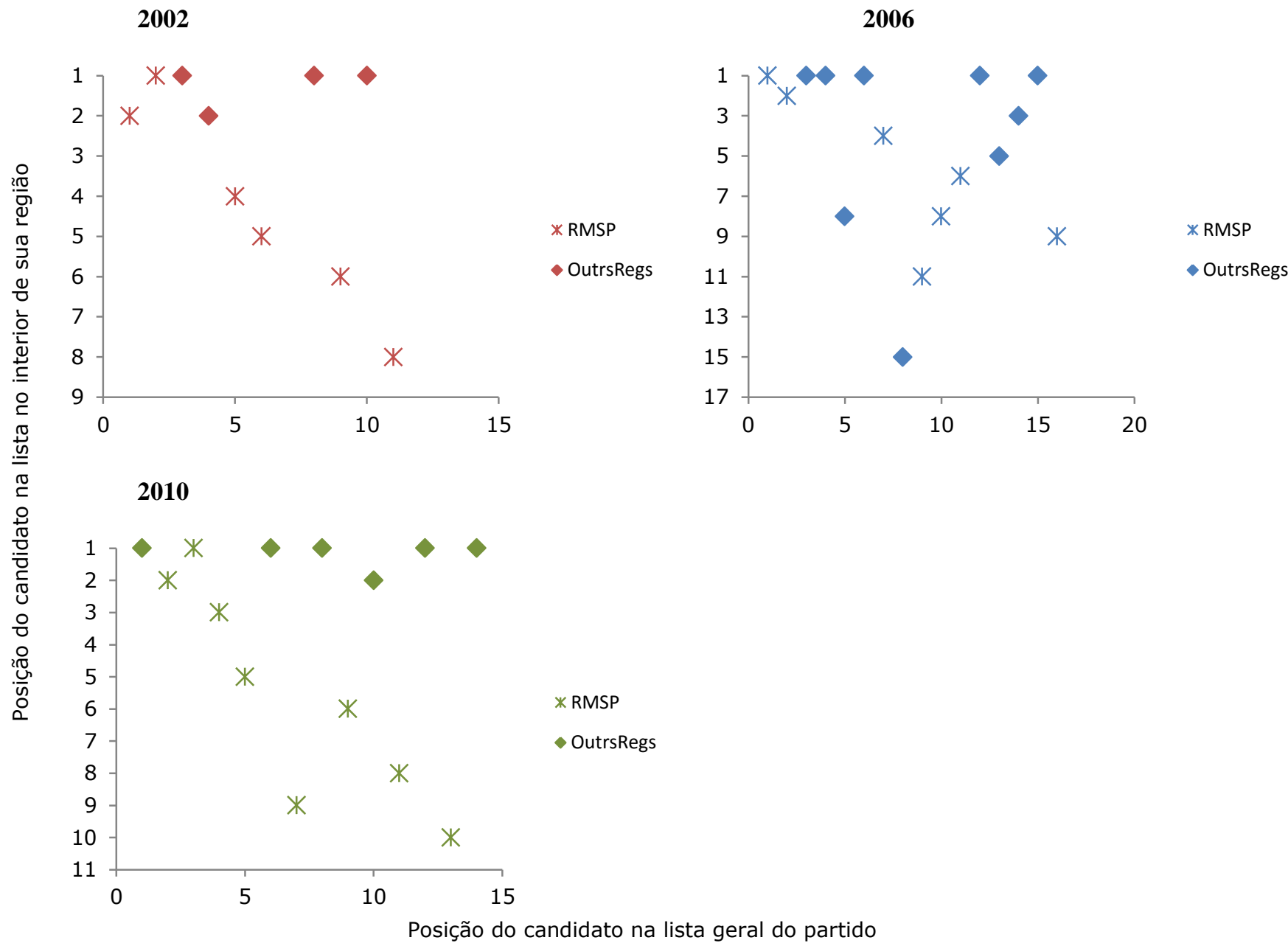

Fonte: TSE. Elaboração Própria.

Considerando os três primeiros lugares no interior de uma região, com exceção do ano de 2006, todos os candidatos regionais do PFL/DEM venceram no interior de suas regiões, estão nos primeiros lugares. Ainda que estes candidatos não sejam os mais votados da lista de todo o partido (como é o caso de 2002 e 2006), no interior de suas regiões eles foram os mais votados.

A análise do caso do PMDB é ainda mais contundente, neste sentido. Todos os candidatos locais venceram no interior de suas regiões, como mostra o gráfico 2 abaixo: 


\section{Gráfico 3 - Posição do candidato na lista geral do partido e na sua respectiva região -}

\section{PMDB}

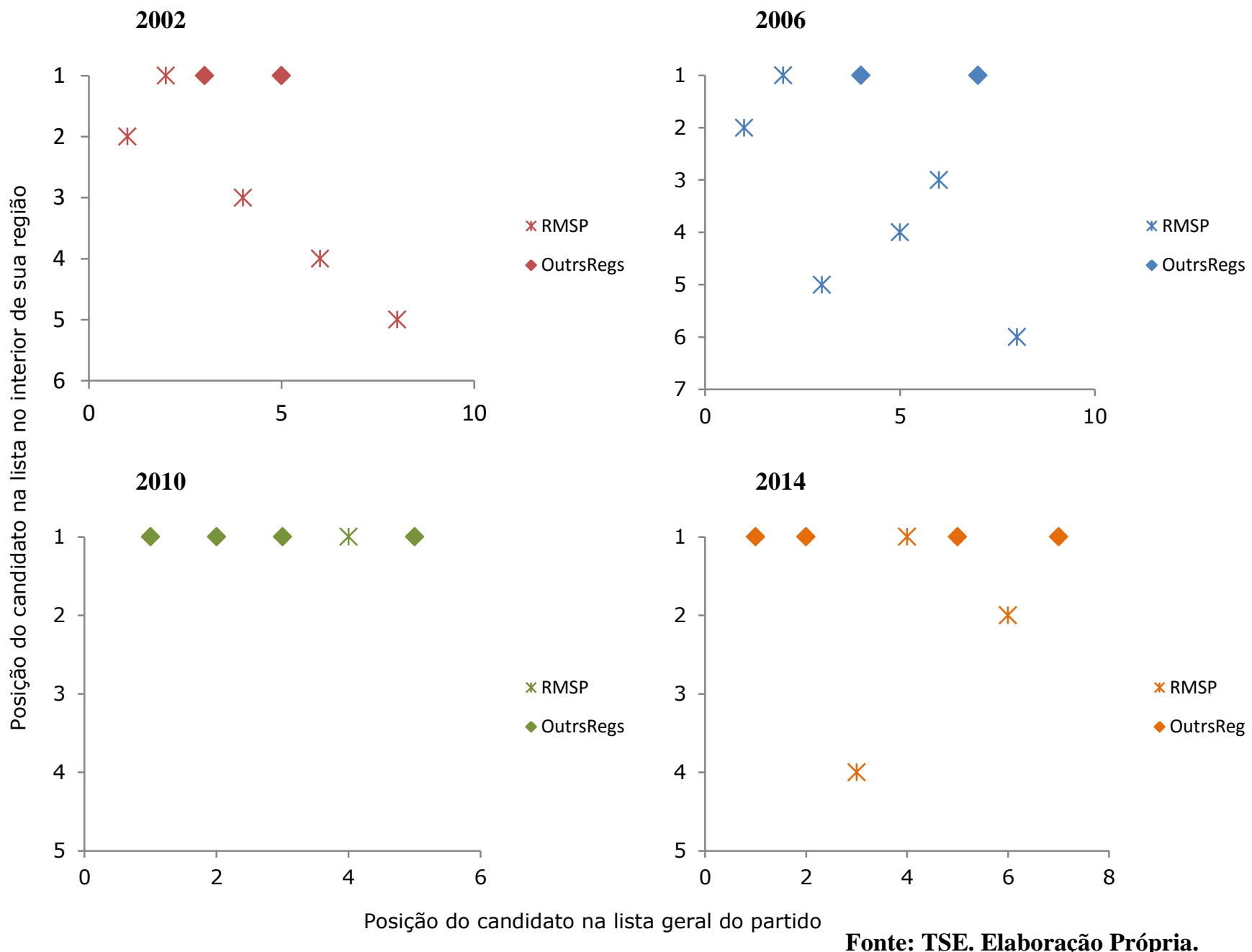

A despeito do baixo número de candidatos competitivos lançados localmente como visto na seção anterior, o PMDB têm sucesso eleitoral em $100 \%$ dos casos: todos os candidatos locais foram os mais votados no interior de suas regiões, não tendo disputado votos com nenhum outro candidato, nem mesmo da RMSP.

Este padrão de sucesso ocorre também no PPB/PP no qual, com exceção de um candidato em 2014, todos os demais candidatos locais tiveram igualmente êxito na conquista do voto do eleitor no interior da sua própria região, conforme evidencia o gráfico 3 abaixo: 


\section{Gráfico 4 - Posição do candidato na lista geral do partido e na sua respectiva região -}

PPB/PP

2002
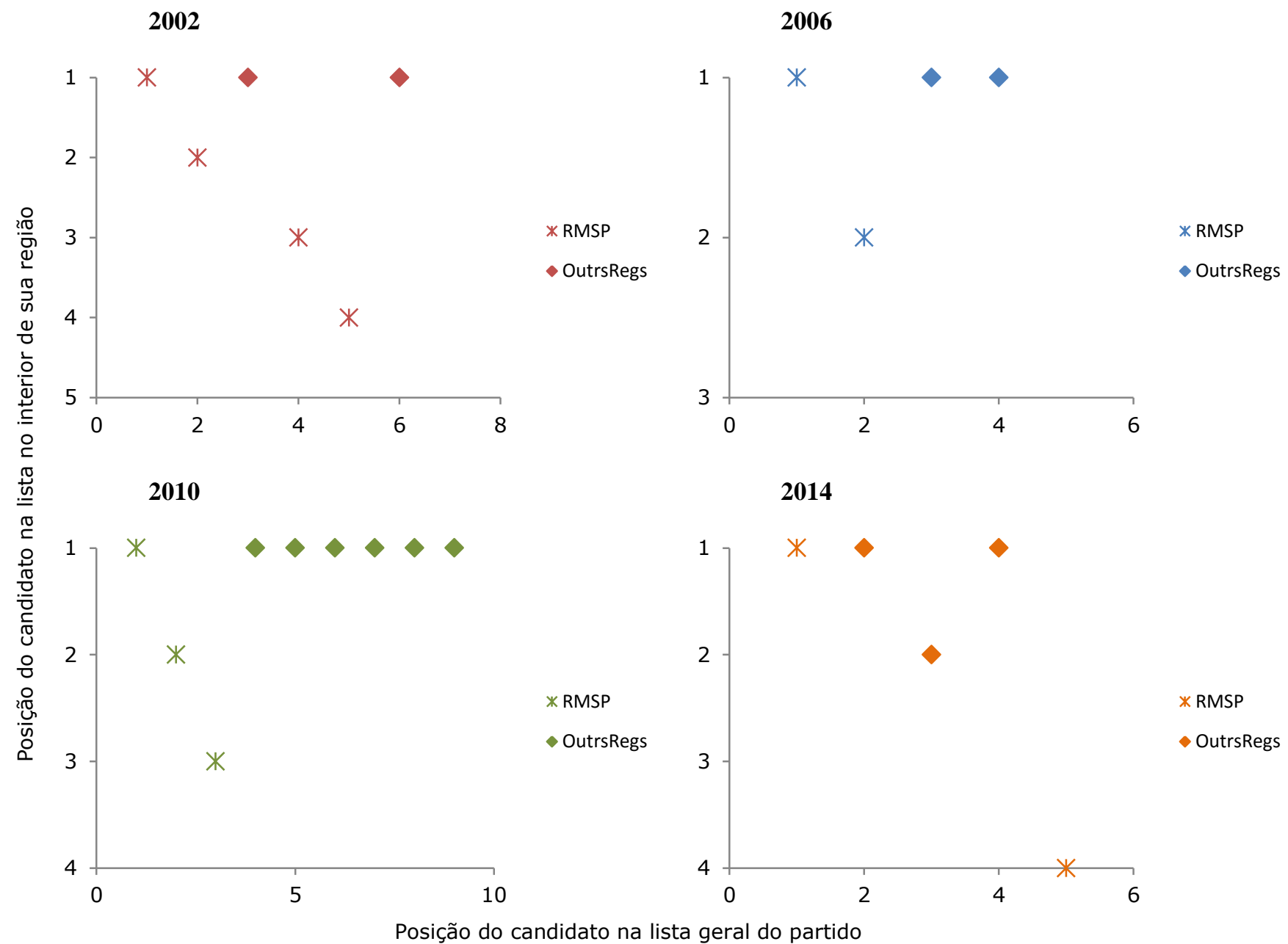

Fonte: TSE. Elaboração Própria.

O caso petista também mostra um padrão de sucesso na obtenção de votos do eleitor regional por parte dos candidatos regionais. Conforme o gráfico 4, a despeito de um leve desvio em 2002, em todos os demais anos os candidatos do PT conseguem vencer no interior de suas regiões. Em 2014, 100\% dos candidatos locais foram os que obtiveram mais votos nas suas regiões. Conforme o argumento da geografia eleitoral, o candidato petista da região de Campinas foi o mais votado na região de Campinas, bem como o de Ribeirão Preto foi o mais votado em sua região. 


\section{Gráfico 5 - Posição do candidato na lista geral do partido e na sua respectiva região - PT}

2002

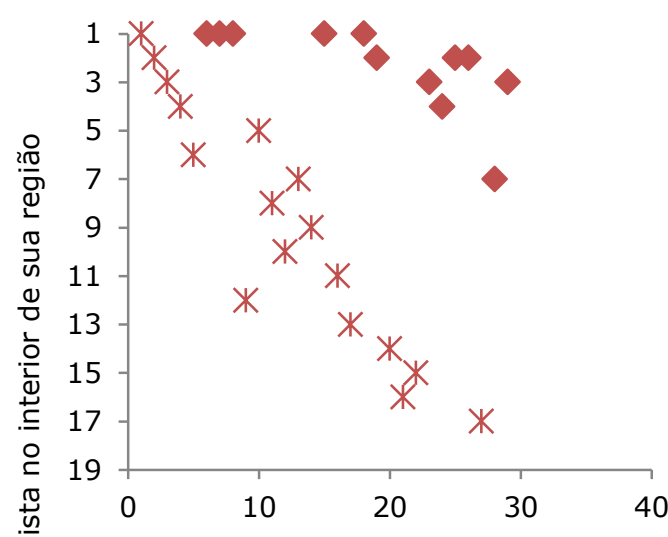

2010

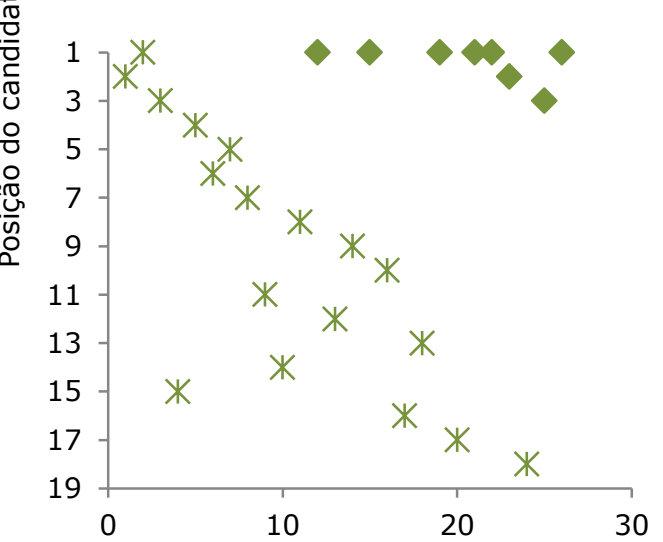

2006

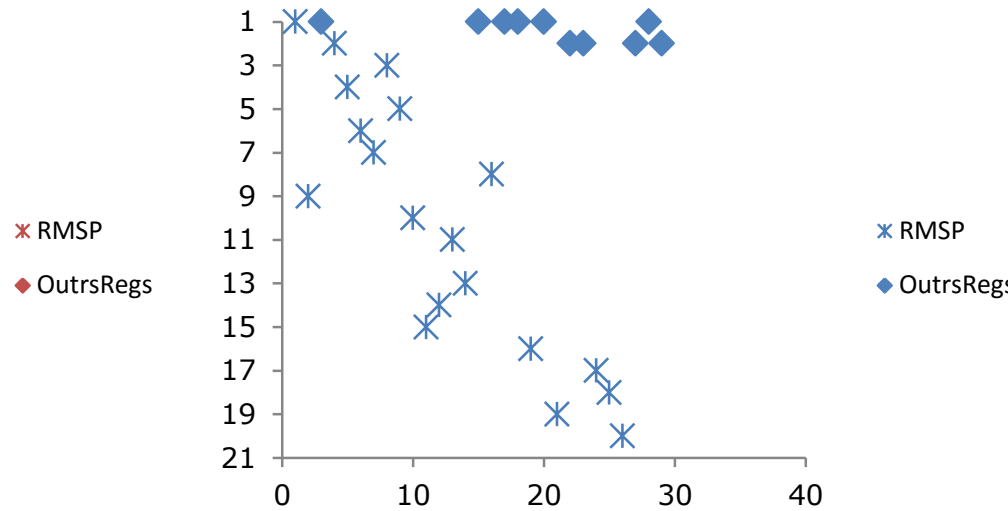

2014

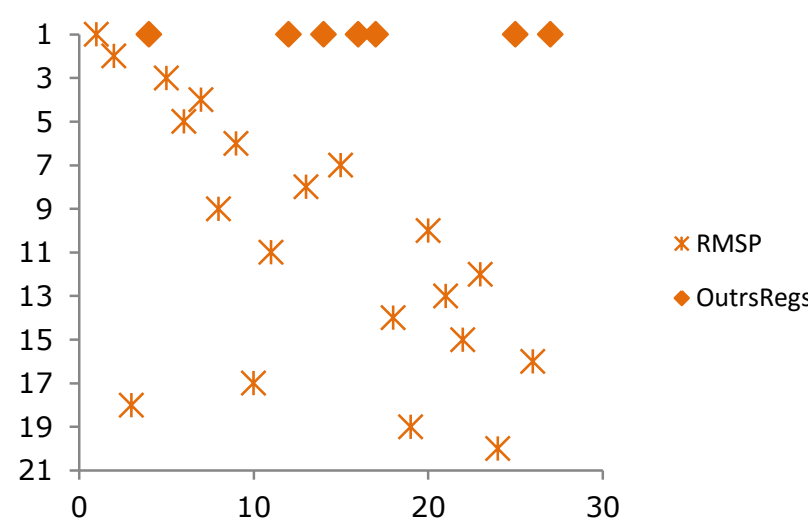

Fonte: TSE. Elaboração Própria.

Os pontos marcados pela RMSP evidenciam os casos em que os candidatos da capital foram os vencedores nas regiões, denotando a facilidade dos candidatos da capital de capilarizarem suas campanhas e votos ao longo do território. Vale ressaltar que, mesmo assim, em menos da metade das vezes eles vencem os candidatos locais de outras regiões, o que aponta que, ainda que o candidato da RMSP consiga "transbordar" os limites regionais impostos pela estrutura geoespacial, poucas vezes ele consegue desbancar os candidatos locais no interior de uma região. Cabe apontar ainda que esses candidatos da RMSP concentram-se sempre no topo da lista do seu próprio partido, o que reforça a diferenciação partidária de um candidato, como apontado por Cheibub e Sin (2015). Isto é, esses candidatos conseguem muitos votos porque são candidatos fortes. Na classificação de Carneiro (2009), eles seriam os puxadores de votos de um partido. 
O caso do PSDB é bastante semelhante, ainda que conte com alguns candidatos mais desviantes que o PT. Conforme o gráfico 4 abaixo, alguns de seus candidatos locais não são os mais votados no interior das suas regiões, mas a concentração de pontos indica uma tendência geral de "topo", como todos os demais partidos analisados.

\section{Gráfico 6 - Posição do candidato na lista geral do partido e na sua respectiva região - PSDB}

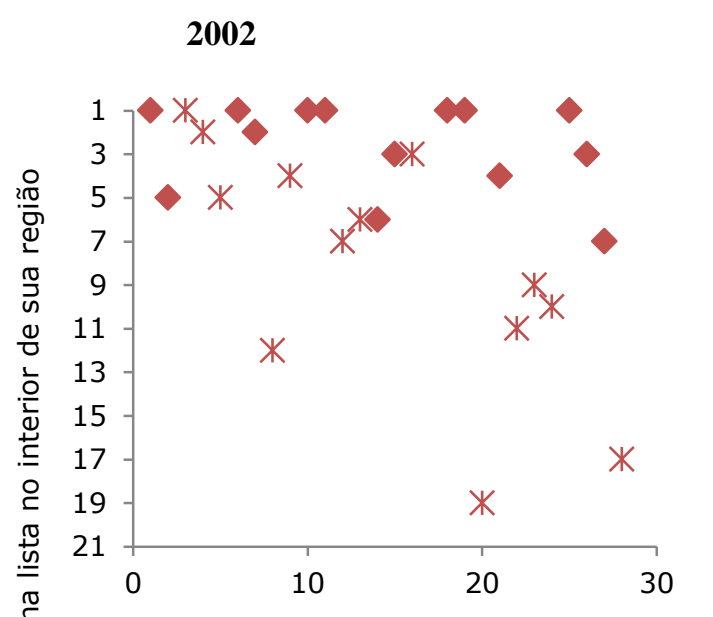

2010

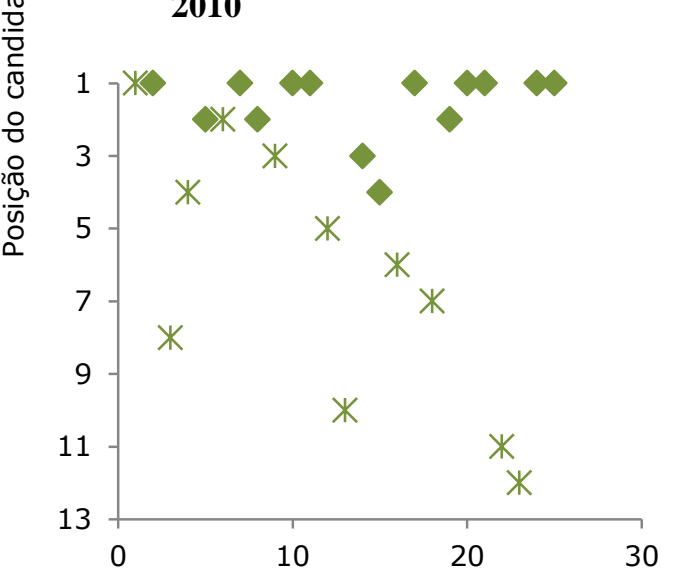

Posição do candidato na lista geral do partido
2006

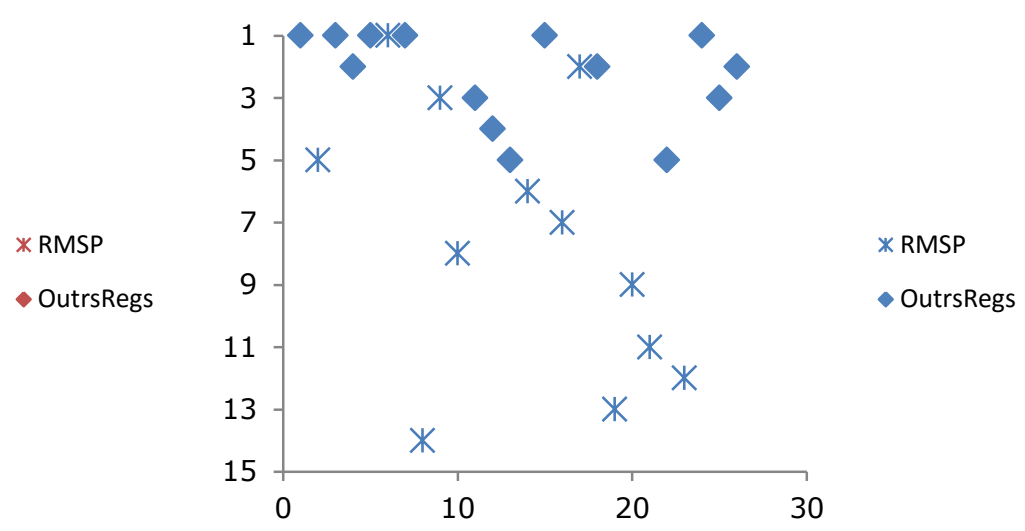

2014

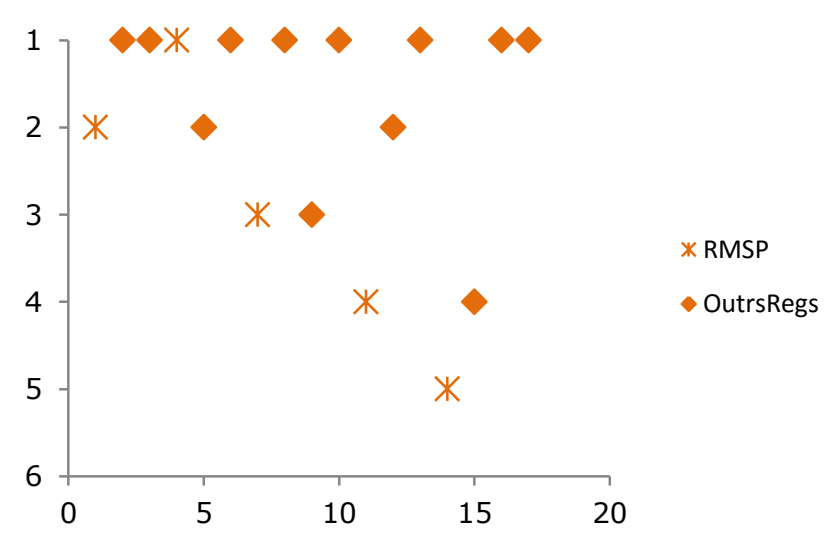

Fonte: TSE. Elaboração Própria.

Essa tendência, por fim, se faz presente também no PSD em 2014. Um pouco mais tímida que nos demais partidos, mas ainda assim segue o padrão de que seus candidatos locais ficam no topo das listas no interior das suas regiões, ainda que não na lista geral do seu partido. Com menos candidatos lançados que os partidos anteriores, o PSD revela candidatos regionais entre os três primeiros mais votados das regiões, a despeito da localização destes no interior do partido como um todo. Conforme o gráfico 6 abaixo. 
Gráfico 7 - Posição do candidato na lista geral do partido e na sua respectiva região - PSD

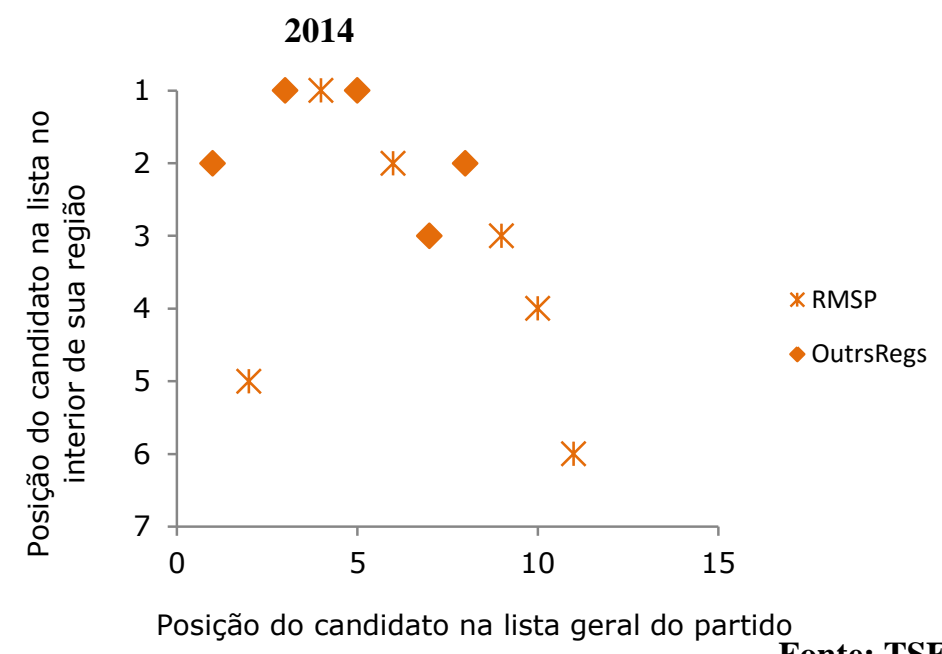

Fonte: TSE. Elaboração Própria.

A análise do sucesso eleitoral dos candidatos no interior de suas regiões mostra que o eleitor corresponde à estratégia do partido. Posto de outra forma, a dinâmica regional que o partido considera ao formular suas listas está presente não apenas na dimensão partidária de alocação de candidatos, mas também na decisão de atribuição de voto do eleitor que mostra preferir, no geral, o candidato local frente a outros candidatos. Em termos concretos, para o eleitor a lógica regional afeta sua escolha que acaba se dando mais pelo candidato "conhecido", aquele cuja campanha é divulgada intensamente na região, que já foi político local e que está nos jornais ou nos outdoors das cidades que estes eleitores frequentam, do que para qualquer outro candidato.

Vale ressaltar, mais uma vez, a diferenciação do candidato da RMSP que consegue votos dispersos geograficamente, independente da região. Esse fenômeno está de acordo com o argumento da geografia eleitoral, e também com Latner e McGann (2005), conforme exposto no capítulo 1 deste trabalho. O "candidato da capital" consegue mais votos fora da sua região porque a capital consegue exercer influência sobre outras regiões com mais facilidade. Ou seja, o candidato de São Paulo consegue votos em Presidente Prudente, mas o candidato de São José dos Campos dificilmente conseguirá. $\mathrm{Na}$ minoria dos casos analisados (apenas cinco), vale pontuar, consegue ${ }^{42}$.

42 Esses desvios acontecem em no máximo três regiões (de quinze) no PT em 2002, no PFL/DEM e no PSDB em 2006, no PPB/PP em 2010 e no PSD em 2014, apenas. Para consultar os dados, ver anexo 7. 
Esse argumento de regionalização de estratégias partidárias e a conquista dos votos regionais pelo candidato local não implica na dominância do eleitorado no mesmo sentido que o argumento distributivista (ver Ames, 2003). Se naquela teoria o eleitor concederia em troca seu voto a um candidato que lhe concede políticas do tipo pork barrel, aqui o refinamento se dá com base nos argumentos da geografia eleitoral. Os candidatos locais conseguem o voto regional por uma dinâmica não política, mas geoespacial. Isso implica que a "lealdade" do eleitor no caso distributivista aqui se vincula à sua cidade, à sua região: é ao político local que o eleitor se mostra fiel, não àquele que lhe destina obras. Político local, frisa-se aqui, porque pouco importa o nome deste político. O que conta, nesta acepção, é a vinculação dele ao espaço, ao mundo geoespacial no qual se assenta o mundo social e o mundo político. 


\section{6 - Considerações Parciais}

$\mathrm{O}$ argumento da geografia eleitoral sobre a existência de um layer engendrado pelo contexto socioespacial que seria a base do mundo social e do mundo político revela-se promissora do ponto de vista partidário. Latner e McGann (2005) mostraram que estratégias regionalistas são utilizadas pelos partidos em sistemas de representação proporcional. Aos distritos nacionais analisados pelos autores (Holanda e Israel) assemelham-se às regiões subdistritais da representação proporcional de lista aberta brasileira. Isto é, a elevada magnitude dos distritos brasileiros possibilita a existência de subdistritos que, dadas as relações originadas e estabelecidas pelas características geoespaciais, constituem-se como regiões no interior de um distrito.

Ao analisado o caso de São Paulo - maior magnitude brasileira - de acordo com as regiões estabelecidas pela Região de Influência das Cidades, Regic, do IBGE, a regionalização mostrou-se presente tanto de uma perspectiva partidária quanto da perspectiva do eleitor. Adequada ao argumento da geografia eleitoral, a definição regional da Regic-IBGE foi delineada por fatores externos à arena política, considerando os movimentos engendrados pela dinâmica do espaço sob a qual se assenta o cotidiano dos eleitores, candidatos e partidos, bem como o fluxo de informações que flui chega até eles. Assim, de dois pontos de vista a Regic mostrou-se consistente: são refletidas nas estratégias dos partidos quanto a distribuição de seus candidatos ao longo do distrito, e refletidas também nos eleitores, que correspondem à ela, ao votar mais nestes candidatos do que em candidatos de outras regiões.

Mais uma vez, não se pretende aqui ressaltar que partidos ou eleitores tenham consciência dessas regiões e ponderem suas decisões por meio delas ativamente. Pelo contrário, a geografia eleitoral afirma que a dinâmica espacial em questão opera naturalmente na vida cotidiana dos atores - partidos ou eleitores -. Dessa forma, é nas relações do dia-a-dia que eleitores têm mais contato com alguns candidatos (locais) do que com outros (não-locais), e é a cada campanha que partidos decidem pela alocação de seus candidatos competitivos de maneira que eles compitam entre si diretamente. $\mathrm{O}$ resultado da alocação dos candidatos pelos partidos é evidente pela distribuição de candidatos entre as regiões. Nenhum partido aloca mais candidatos competitivos numa determinada região do que seu potencial eletivo, portanto, estes candidatos competitivos não competem entre si do ponto de vista regional. Vale afirmar que intertemporalmente 
não foi possível verificar uma dinâmica clara, ou um padrão sobre se os partidos buscam "preencher" com candidatos as regiões que eles não se faziam presentes anteriormente. Ainda assim, é possível afirmar que partidos respondem à lógica das regiões do estado para contornar a competição intrapartidária em cada eleição.

Essa resposta ao layer geoespacial pode ser verificada também no comportamento dos eleitores. A análise mostrou que os candidatos locais são mais votados no interior de suas regiões que outros candidatos, à exceção daqueles cuja origem é a grande metrópole nacional, São Paulo. Em outras palavras, a relação de proximidade consegue fazer com que o voto do eleitor seja concedido ao candidato local, e dificulta a vitória do candidato "estrangeiro" porque este não consegue atingir este eleitorado com facilidade. Ao menos, não sem uma extensa construção partidária de sua candidatura na região que ele pretende se inserir, o que acarreta custos financeiros e partidários podendo revelar-se pouco vantajoso de um ponto de vista partidário-maximizador. 


\section{CONCLUSÕES}

O cenário no qual partidos, atores estratégicos que organizam a arena eleitoral, tomam suas decisões é imerso em restrições que emergem dos incentivos gerados pelo sistema eleitoral brasileiro. É necessário, assim, que os partidos lidem com essas restrições e incentivos de forma que possam atingir, sob os menores custos, o máximo sucesso eleitoral possível. Esse é o objetivo dessas agremiações coletivas. Ainda que existam muitas motivações às estratégias dos partidos, todas elas devem enfrentar as restrições institucionais da legislação que rege as eleições.

Assim, partidos, que têm prerrogativas legais para atuarem no processo eleitoral, precisam lidar com os incentivos que emanam, principalmente, da lista aberta e das magnitudes dos distritos, cujo número é bastante elevado. Dessas duas características emergem, de um lado, a centralidade do candidato frente ao partido e, de outro, um incentivo ao alto número de candidatos - o que pode gerar competição intrapartidária e os elevados custos às campanhas eleitorais, dada a extensão dos territórios de $\mathrm{M}$ grande.

Nesse sentido, há incentivos para a estratégia de regionalização seja porque eles estão presentes em qualquer formato de sistema institucional (Latner \& McGann, 2005), seja porque a extensão territorial aumenta os custos e cria obstáculos para as campanhas em distritos grandes (Ames, 2003). Mas diferente do controverso (ver Figueiredo \& Limongi, 2002) caráter distributivista dessas regiões apontado por Ames, assume-se aqui que há uma motivação alternativa por trás dele: a estrutura da competição originaria a opção regionalista aos atores políticos e aos eleitores.

A proposta deste trabalho foi, de certa forma, dialogar com esses estudos que primeiramente apontaram os incentivos à regionalização, mas acrescentar à eles outras duas dimensões, a partidária e a de que a competição, a magnitude dos distritos e a lista aberta despertam incentivos à formação de subdistritos, ou nas palavras de Ames, constituencies. Longe de corroborá-los, o intuito foi mostrar que ao fenômeno da subdistritalização há uma alternativa teórica que argumenta não pelo distributivismo, mas por um sistema eleitoral que traz o elemento regional ao plano das decisões partidárias, isto é, a subdistritalização em decorrência da ação intencional política que, com isso, garantiria a ausência ou diminuição da competição intrapartidária no 
território. $\mathrm{O}$ intuito da pesquisa, nesse ínterim, foi verificar se essas regiões faziam sentido quando se observa a questão pela ótica da formação estratégica das listas de candidatos pelos partidos.

Dois foram os esforços necessários nessa pesquisa. O primeiro, definir as regiões do distrito paulista analisado de acordo com uma proposta exógena à arena política. Conforme o argumento da geografia eleitoral, a arena política se assenta sob estes distritos e, portanto era preciso encontrar uma definição capaz de captar os movimentos possibilitados pela dinâmica do espaço a fim de verificá-las sob o prisma da arena política. A Região de Influência das Cidades, Regic, do IBGE foi a alternativa escolhida para tal. Elaborada com base nos fluxos de informação e pessoas entre as cidades, a pesquisa desenvolveu uma hierarquização de municípios que serviu como base para a formação de regiões no interior dos estados. Conforme o argumento, sob esta definição regional assenta-se o mundo social e político, e foi com base nela que esta pesquisa explorou a dimensão partidária da análise proposta.

O segundo esforço consistiu em analisar como os partidos se apropriam dessa dimensão regional quando da elaboração de suas listas de candidatos. Os resultados mostraram que a Regic reflete bem a dinâmica da alocação regional de candidatos por parte dos partidos. Desta perspectiva, a distribuição de candidatos entre as regiões sugere que as agremiações conseguem contornar os incentivos que geram competição intrapartidária por meio de tal estratégia na formação de suas listas de candidatos. Sob a perspectiva da regionalização, partidos alocam candidatos de forma que eles conseguem obter votos de suas regiões sem ter que disputar com candidatos de outras regiões, onde estes têm sucesso eleitoral, igualmente. Soma-se a isso o fato de que o resultado eleitoral no interior dessas regiões do estado de São Paulo sugere exatamente o mesmo: os votos regionais são majoritariamente conquistados pelos candidatos locais. Praticamente inexistem casos que candidatos locais de uma região perdem votos para candidatos de outras regiões.

Dessa forma, duas são as contribuições desta pesquisa. De um lado, tanto partidos, quando da alocação de candidatos na lista, quanto eleitores, na decisão do voto, são influenciados por uma dinâmica regional sob a qual estão postas tanto a arena política quando a arena em que se dá a vida cotidiana das pessoas. De outro, os achados sugerem que suas atitudes e estratégias consideram esse caráter regional, em 
consonância com a teoria da geografia eleitoral e também com aquela que deriva das instituições políticas os incentivos à regionalização eleitoral.

Nesse cenário promissor, uma série de alternativas se abrem. Essa investigação se deu sobre o plano do legislativo nacional, mas como partidos agem desta perspectiva quando o pleito em questão é para cargos dos legislativos estaduais? A lista aberta neste caso funciona como na escolha dos deputados federais? Ou o número de candidatos elevado no nível estadual altera a dinâmica desta competição? Além disso, cabe explorar como a dinâmica interna das regiões influencia a escolha dos candidatos, isto é, candidatos são escolhidos de acordo com o passado político local de cidades hierarquicamente superiores, ou a força dessas cidades sobre as demais não é um fator considerado na escolha do candidato em si? Além disso, verificar se os candidatos desses municípios de grau maior na hierarquia têm um alcance maior sobre outras regiões, isto é, verificar se um candidato de São Paulo alcança mais votos "estrangeiros" do que um candidato da cidade de Guarulhos, por exemplo. Os dados mostram que candidatos da RMSP frequentemente conseguem votos em regiões distantes, mas não candidatos de outras regiões. Isto é, candidatos da RMSP conseguem votos em Ribeirão Preto, mas candidatos de Ribeirão Preto não conseguem votos em Santos, por exemplo. É possível ainda explorar como os partidos escolhem quando consideram o ângulo do carreirismo político e das suas próprias estratégias.

Por fim, muitas são as alternativas de pesquisa que estas conclusões suscitam. Este trabalho fez uma incursão no sentido de reforçar que o meio social e o político respondem aos fatores regionais, que influencia suas atitudes e estratégias. Essa característica contribui para que partidos possam contornar incentivos perversos da legislação, como a competição intrapartidária, e com isso otimizar seus resultados eleitorais. Isso se faz possível por meio dessa dinâmica não política, mas geoespacial na qual estão alicerçados todo o mundo político e social. O fator regional apresenta-se, portanto, como uma dimensão em potencial para as futuras análises político-eleitorais. 


\section{BIBLIOGRAFIA}

Agnew, J. (1996). Mapping politics: how context counts in electoral geography. Political Geography, 15(2), 129-146.

Agnew, J. A. (1987). Place and Politics: The Geographical Mediation of State and Society. Allen \& Unwin.

Álvares, M. L. M. (2008). Brazilian women in electoral contests: candidate selection and degree of access to congressional office. Dados, 51(4), 895-939.

Amaral, O. E. do. (2013). The changes in the forms of militancy within the PT: greater inclusion and lesser intensity. Revista Brasileira de Ciências Sociais, 28(82), 6786.

Amaral, O. M. E. do, \& Meneguello, R. (2010, December 17). As transformações na organização interna do Partido dos Trabalhadores entre 1995 e 2009 [Tese de Doutorado].

Ames, B. (1995). Electoral Strategy under Open-List Proportional Representation. American Journal of Political Science, 39(2), 406-433.

Ames, B. (2003). Os entraves da democracia no Brasil. FGV Editora.

Araújo, C. (2001a). Analyzing Strategies: The Potentials and Limits of Quota Policies in Brazil. Revista Estudos Feministas, 9(1), 231-252.

Araújo, C. (2001b). Gender quotas for candidacy to the legislature: the Brazilian case as compared to international experience. Dados, 44(1), 0-0.

Araújo, C. (2009). Gênero e acesso ao poder legislativo no Brasil: as cotas entre as instituições e a cultura. Revista Brasileira de Ciência Política, O(2), 23-59.

Araújo, C., \& Alves, J. E. D. (2007). Social indicators and electoral system's impacts on women's chances in elections and their interactions with the mechanism of quotas. Dados, 50(3), 535-577. 
Araújo, C., \& Borges, D. (2013). Trajetórias Políticas e Chances Eleitorais: Analisando o "gênero"das candidaturas em 2010. Revista de Sociologia e Política, 21(46).

Benoit, K. (2001). District magnitude, electoral formula, and the number of parties. European Journal of Political Research, 39(2), 203-224.

Bolognesi, B. (2013). The candidate selection in DEM, PMDB, PSDB and PT in the Brazilian's 2010 federal legislative elections: candidates perception from party list building. Revista de Sociologia E Política, 21(46), 45-68.

Braga, M. do S. S. (2008a). Organizações partidárias e seleção de candidatos no estado de São Paulo. Opinião Pública, 14(2), 454-485.

Braga, M. do S. S. (2008b). Organizações partidárias e seleção de candidatos no estado de São Paulo. Opinião Pública, 14(2), 454-485.

Braga, M. do S. S., \& Amaral, O. E. do. (2013). Candidate selection and party competition: the case of Brazil. Revista de Sociologia E Política, 21(46), 33-43.

Braga, M. do S. S., Veiga, L. F., \& Miríade, A. (2009a). Recruitment and profile of candidates and the elected to the Chamber of Deputies in the elections of 2006. Revista Brasileira de Ciências Sociais, 24(70), 123-142.

Braga, M. do S. S., Veiga, L. F., \& Miríade, A. (2009b). Recrutamento e perfil dos candidatos e dos eleitos à Câmara dos Deputados nas eleições de 2006. Revista Brasileira de Ciências Sociais, 24(70), 123-142.

Burbank, M. J. (1997). Explaining Contextual Effects on Vote Choice. Political Behavior, 19(2), 113-132.

Cain, B., Ferejohn, J., \& Fiorina, M. (1987). The Personal Vote - Constituency Service and Electoral Independence. Cambridge: Harvard University Press.

Carey, J. M., \& Hix, S. (2011). The Electoral Sweet Spot: Low-Magnitude Proportional Electoral Systems. American Journal of Political Science, 55(2), 383-397.

Carey, J. M., \& Shugart, M. S. (1995). Incentives to cultivate a personal vote: A rank ordering of electoral formulas. Electoral Studies, 14(4), 417-439. 
Carvalho, N. R. de. (2003). E no início eram as bases: geografia política do voto e comportamento legislativo no Brasil. Editora Revan.

Cervi, E. U. (2010). Financiamento de campanhas e desempenho eleitoral no Brasil: análise das contribuições de pessoas físicas, jurídicas e partidos políticos às eleições de 2008 nas capitais de Estado. Revista Brasileira de Ciência Política, O(4), 135167.

Chang, E. C. C., \& Golden, M. A. (2007). Electoral Systems, District Magnitude and Corruption. British Journal of Political Science, 37(1), 115-137.

Cheibub, J. A., \& Sin, G. (2015). Order in Chaos: Intraparty Coordination in Open List PR Systems. Presented at the 73rd MPSA Annual Conference, Chicago, EUA.

Cox, G. W., \& McCubbins, M. D. (1993). Legislative Leviathan: Party Government in the House. Berkeley: University of California Press.

Czudnowski, M. M. (1970). Legislative Recruitment under Proportional Representation in Israel: A Model and a Case Study. Midwest Journal of Political Science, 14(2), 216.

Dyck, J. J., Gaines, B. J., \& Shaw, D. R. (2009). The Effect of Local Political Context on How Americans Vote. American Politics Research, 37(6), 1088-1115.

Farrell, D. M. (2011). Electoral Systems: A Comparative Introduction. Palgrave Macmillan.

Figueiredo, A. C., \& Limongi, F. (2002a). Incentivos Eleitorais, Partidos e Política Orçamentária. Dados, 45(2).

Figueiredo, A. C., \& Limongi, F. (2002b). Incentivos Eleitorais, Partidos e Política Orçamentária. Dados - Revista de Ciências Sociais, 45(2), 303-344.

Freidenberg, F. (2003). Selección de Candidatos y Democracia Interna en los Partidos de la América Latina.

Gallagher, M., \& Marsh, M. (1988). Candidate Selection in Comparative Perspective: The Secret Garden of Politics. Londres: SAGE. 
Guarnieri, F. (2004). Partidos, seleção de candidatos e comportamento político. Universidade de São Paulo, São Paulo.

Guarnieri, F. (2011). A força dos partidos fracos. Dados, 54(1), 235-258.

Guarnieri, F. (2012). Organização partidária e mobilização eleitoral no Brasil: o elo perdido. In $8^{\circ}$ encontro da $A B C P$. Brasília, DF.

Hazan, R. Y. (2002). Candidate Selection. In Comparing Democracies 2: New Challenges in the Study of Elections and Voting. SAGE.

Hazan, R. Y., \& Rahat, G. (2010). Democracy within Parties: Candidate Selection Methods and their Political Consequences. Oxford; New York: Oxford University Press.

Helander, V. (1997). Finland. In Passages to Power. Legislative Recruitment in advanced democracies. Cambridge University Press: Norris, $\mathrm{P}$.

Homans, G. C. (1988). Behaviourism and after. In Social Theory Today. Giddens, A. Stanford University Press.

Htun, M., \& Power, T. J. (2006). Gender, Parties, and Support for Equal Rights in the Brazilian Congress. Latin American Politics and Society, 48(4), 83-104.

Huckfeldt, R., \& Sprague, J. (1987). Networks in Context: The Social Flow of Political Information. The American Political Science Review, 81(4), 1197-1216.

IBGE. (2007). Regiões de influência das cidades. Rio de Janeiro: Ministério do Planejamento, Orçamento e Gestão - IBGE.

Jankowski, M. (2016). Voting for locals: Voters' information processing strategies in open-list PR systems. Electoral Studies, 43, 72-84.

Key, V. O. (1949). Southern politics in State and Nation. A. A. Knopf.

Kinzo, M. D. G. (2004). Partidos, eleições e democracia no Brasil pós-1985. Revista Brasileira de Ciências Sociais, 19(54), 23-40. 
Lamounier, B. (1992). Estrutura Institucional e governabilidade na década de 1990. In J. P. dos Reis Velloso, O Brasil e as reformas políticas. Rio de Janeiro: J. Olympio Editora.

Latner, M., \& McGann, A. (2005). Geographical representation under proportional representation: The cases of Israel and the Netherlands. Electoral Studies, 24(4), 709-734.

Lau, R. R., \& Redlawsk, D. P. (2006). How Voters Decide: Information Processing in Election Campaigns. Cambridge University Press.

Lembo, C. (1999). O futuro da liberdade: estudos e circunstâncias. Edicoes Loyola.

Lijphart, A. (1977). Democracy in Plural Societies: A Comparative Exploration. Yale University Press.

Lijphart, A. (1999). Patterns of Democracy: Government Forms and Performance in Thirty-six Countries. Yale University Press.

Maciel, N. R. A. (2014). Velhas Raposas, Novos Governistas: o PMDB e a Democracia Brasileira. Universidade Estadual do Rio de Janeiro, Rio de Janeiro.

Mainwaring, S. (1990). Politicians, Parties and Electoral Systems: Brazil in Comparative Perspective. University of Notre Dame, Helen Kellogg Institute for International Studies.

Mainwaring, S. (1991). Políticos, partidos e sistemas eleitorais. Novos Estudos, 29, 3458.

Mainwaring, S. (1991). Políticos, partidos e sistemas eleitorais: o Brasil numa perspectiva comparada. Novos Estudos - CEBRAP, 29, 34-58.

Mainwaring, S. (1999). Rethinking Party Systems in the Third Wave of Democratization: The Case of Brazil (1 edition). Stanford, Calif.: Stanford University Press. 
Marenco, A., \& Serna, M. (2007a). Por que carreiras políticas na esquerda e na direita não são iguais? Recrutamento legislativo em Brasil, Chile e Uruguai. Revista Brasileira de Ciências Sociais, 22(64), 93-113.

Marenco, A., \& Serna, M. (2007b). Why left and right do not have the same political careers? Legislative recruitment in Brazil, Chile, and Uruguay. Revista Brasileira de Ciências Sociais, 22(64), 93-113.

Marsh, M. (1987). Electoral evaluations of candidates in Irish general elections 194882. Irish Political Studies, 2(1), 65-76. http://doi.org/10.1080/07907188708406437

Mayhew, D. R. (1974). Congress: The Electoral Connection. Yale University Press.

McPhee, W. N. (1972). A theory of informal social influence.

Meneguello, R. (1989). PT: a formação de um partido, 1979-1982. Paz e Terra.

Mesquita, L. (2008). Emendas ao orçamento e conexão eleitoral na Câmara dos Deputados Brasileira (Dissertação de Mestrado). Universidade de São Paulo, São Paulo.

Mesquita, L., Silotto, G., Luz, J., \& Hubert, P. (2014). Emendas Individuais e Concentração de Votos: uma análise exploratória. Teoria E Pesquisa, 23(2), 82106.

Mucinhato, R. M. D. (2015). Um passo adiante, dois passos para trás: o PMDB de 1979 a 1982 (text). Universidade de São Paulo.

Nicolau, J. (2006). The open-list of electoral system in Brazil. Dados, 49(4), 689-720.

Norris, P. (1993). Gender and Party Politics (annotated edition edition). London; Thousand Oaks, Calif: SAGE Publications Ltd.

Norris, P. (1997). Passages to Power: Legislative Recruitment in Advanced Democracies. Cambridge University Press.

Norris, P. (2004). Electoral Engineering: Voting Rules and Political Behavior. Cambridge University Press. 
Norris, P., \& Lovenduski, J. (1995). Political Recruitment: Gender, Race and Class in the British Parliament. Cambridge University Press.

Norris, P., \& Lovenduski, J. (2010). Puzzles in political recruitment. In Women, Gender and Politics: a reader. Oxford University Press: Krooks and Childs.

North, D. C. (1990). Institutions, Institutional Change and Economic Performance. Cambridge University Press.

Pattie, C., \& Ron Johnston. (2000). "People Who Talk Together Vote Together": An Exploration of Contextual Effects in Great Britain. Annals of the Association of American Geographers, 90(1), 41-66.

Pereira, C., \& Mueller, B. (2003a). Partidos fracos na arena eleitoral e partidos fortes na arena legislativa: a conexão eleitoral no Brasil. Dados, 46(4), 735-771.

Pereira, C., \& Mueller, B. (2003b). Weak parties in the electoral arena, strong parties in the legislative arena: the electoral connection in Brazil. Dados, 46(4), 735-771.

Pereira, C., \& Renno, L. (2007). What does the reelected have?The return: the outline of a reelection theory in Brazil. Revista de Economia Política, 27(4), 664-683.

Peres, P. S. (2008). Behavior or institutions? The historical basis of the neoinstitutionalism in the political sciences. Revista Brasileira de Ciências Sociais, 23(68), 53-71.

Perissinotto, R. M., \& Miríade, A. (2009). Paths to congress: candidates running for and elected to the Brazilian chamber of deputies in 2006. Dados, 52(2), 301-333.

Potter, J. D., \& Olivella, S. (2015). Electoral strategy in geographic space: Accounting for spatial proximity in district-level party competition. Electoral Studies, 40, 7686.

Praça, S., Freitas, A., \& Hoepers, B. (2012). A rotatividade dos servidores de confiança no governo federal brasileiro, 2010-2011. Novos Estudos - CEBRAP, (94), 91-107.

Rae, D. W. (1995). Using District Magnitude to Regulate Political Party Competition. The Journal of Economic Perspectives, 9(1), 65-75. 
Rahat, G. (2007). Candidate Selection: The Choice Before the Choice. Journal of Democracy, 18(1), 157-170.

Ranney, A. (1981). Candidate Selection. In Democracy at the polls: a comparative study of competitive national elections (American Enterprise Institute). Washington: BUTLER, David / PENNIMAN, Howard R. / RANNEY, Austin.

Ribeiro, P. F. (2013). Organização e poder nos partidos brasileiros: uma análise dos estatutos. Revista Brasileira de Ciência Política, O(10), 225-265.

Ribeiro, P. F. (2014). An Amphibian Party? Organisational Change and Adaptation in the Brazilian Workers' Party, 1980-2012. Journal of Latin American Studies, $46(1), 87-119$.

Rodrigues, L. M. (2002). Partidos, ideologia e composição social: um estudo das bancadas partidárias na Câmara dos Deputados. São Paulo: Edusp.

Rodrigues, L. M. (2006). Mudanças na Classe Política Brasileira. São Paulo: Publifolha.

Roma, C. (2002). A institucionalização do PSDB entre 1988 e 1999. Revista Brasileira de Ciências Sociais, 17(49), 71-92.

Sacchet, T., \& Speck, B. W. (2012). Financiamento eleitoral, representação política e gênero: uma análise das eleições de 2006. Opinião Pública, 18(1), 177-197.

Samuels, D. (1997). Determinantes do Voto Partidário em Sistemas Eleitorais Centrados no Candidato: Evidências sobre o Brasil. Dados, 40(3).

Samuels, D. (2001). Money, Elections, and Democracy in Brazil. Latin American Politics and Society, 43(2), 27.

Samuels, D. J. (2002). Pork Barreling Is Not Credit Claiming or Advertising: Campaign Finance and the Sources of the Personal Vote in Brazil. The Journal of Politics, 64(3), 845-863.

Santos, F. G. M. (2003). O poder legislativo no presidencialismo de coalizão. Editora UFMG. 
Schattschneider, E. E. (1942). Party Government. Holt, Rinehart and Winston.

Schmitt, R., Carneiro, L. P., \& Kuschnir, K. (1999). Campaign strategies used in free airtime in proportional elections. Dados, 42(2), 00-00.

Shugart, M. S., Valdini, M. E., \& Suominen, K. (2005a). Looking for Locals: Voter Information Demands and Personal Vote-Earning Attributes of Legislators under Proportional Representation. American Journal of Political Science, 49(2), 437449.

Shugart, M. S., Valdini, M. E., \& Suominen, K. (2005b). Looking for Locals: Voter Information Demands and Personal Vote-Earning Attributes of Legislators under Proportional Representation. American Journal of Political Science, 49(2), 437449.

Siavelis, P. M., \& Morgenstern, S. (2008). Candidate Recruitment and Selection in Latin America: A Framework for Analysis. Latin American Politics and Society, 50(4), 27-58.

Souza, C. (2001). Federalism and social expenditure in Brazil: tensions and tendencies. Lua Nova: Revista de Cultura E Política, (52), 5-28.

Speck, B. W., \& Mancuso, W. P. (2014). A study on the impact of campaign finance, political capital and gender on electoral performance. Brazilian Political Science Review, 8(1), 34-57.

Steinmo, S., Thelen, K., \& Longstreth, F. (1992). Structuring Politics: Historical Institutionalism in Comparative Analysis. Cambridge University Press.

Tavits, M. (2010). Effect of Local Ties On Electoral Success and Parliamentary Behaviour The Case of Estonia. Party Politics, 16(2), 215-235.

Terron, S. L. (2009). A composição de territórios eleitorais no Brasil: uma análise das votações de Lula (1989-2006). Instituto Universitário de Pesquisas do Rio de Janeiro, IUPERJ, Rio de Janeiro.

Terron, S. L., \& Soares, G. A. D. (2010). As bases eleitorais de Lula e do PT: do distanciamento ao divórcio. Opinião Pública, 16(2), 310-337. 
Anexo 1 - Magnitudes dos distritos brasileiros

\begin{tabular}{|c|c|}
\hline Estado & Magnitude \\
\hline São Paulo & 70 \\
\hline Minas Gerais & 53 \\
\hline Rio de Janeiro & 46 \\
\hline Bahia & 39 \\
\hline Rio Grande do Sul & 31 \\
\hline Paraná & 30 \\
\hline Pernambuco & 25 \\
\hline Ceará & 22 \\
\hline Maranhão & 18 \\
\hline Goiás & 17 \\
\hline Pará & 17 \\
\hline Santa Catarina & 16 \\
\hline Paraíba & 12 \\
\hline Espírito Santo & 10 \\
\hline Piauí & 10 \\
\hline Alagoas & 9 \\
\hline Acre & 8 \\
\hline Amazonas & 8 \\
\hline Amapá & 8 \\
\hline Distrito Federal & 8 \\
\hline Mato Grosso do Sul & 8 \\
\hline Mato Grosso & 8 \\
\hline Rio Grande do Norte & 8 \\
\hline Rondônia & 8 \\
\hline Roraima & 8 \\
\hline Sergipe & 8 \\
\hline Tocantins & 8 \\
\hline Total & 513 \\
\hline Mediana & 10 \\
\hline Média & 19 \\
\hline
\end{tabular}

Fonte: TSE. Elaboração Própria. 


\section{Anexo 2 - Regic}

A operacionalização dos dados da Regic/IBGE correspondentes ao estado de São Paulo se deu da seguinte forma: uma vez que a matriz das regiões de influência do estado não possui um mesmo desenho para todos os municípios (Quadro 1) - isto é, nem todas as cidades abaixo do nível 1A estão no nível 2A, mas algumas estão no nível 2B, ou 2C, etc. -, o primeiro nível utilizado para sua subdivisão como área de influência foi o primeiro que aparecia logo após o nível da Grande Metrópole Nacional (São Paulo, que é referência e influência para toda a rede urbana brasileira), independente do nível que fosse. No caso exemplificado, os municípios utilizados foram, portanto, Santos (2C) e Ourinhos (3A). A partir disso foi possível chegar ao Mapa $\mathrm{x}$ abaixo e, simplificadamente ao Mapa 1 do Capítulo 3. 
Quadro 1 - Exemplo de estrutura da matriz das regiões de influência

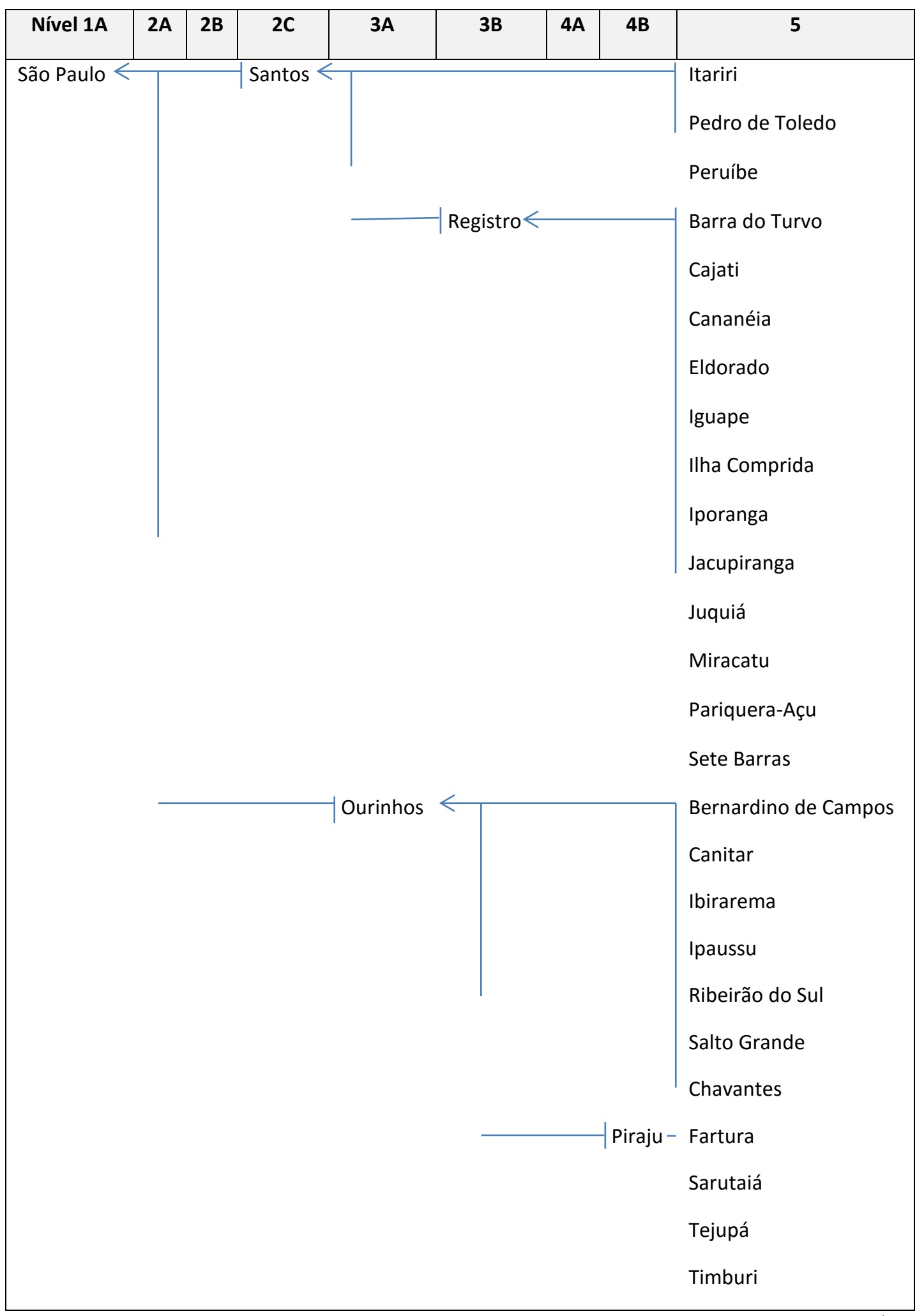

Fonte: Regic - IBGE. Elaboração Própria. 
Mapa 16 - Região de Influência das cidades de São Paulo de acordo com a hierarquia

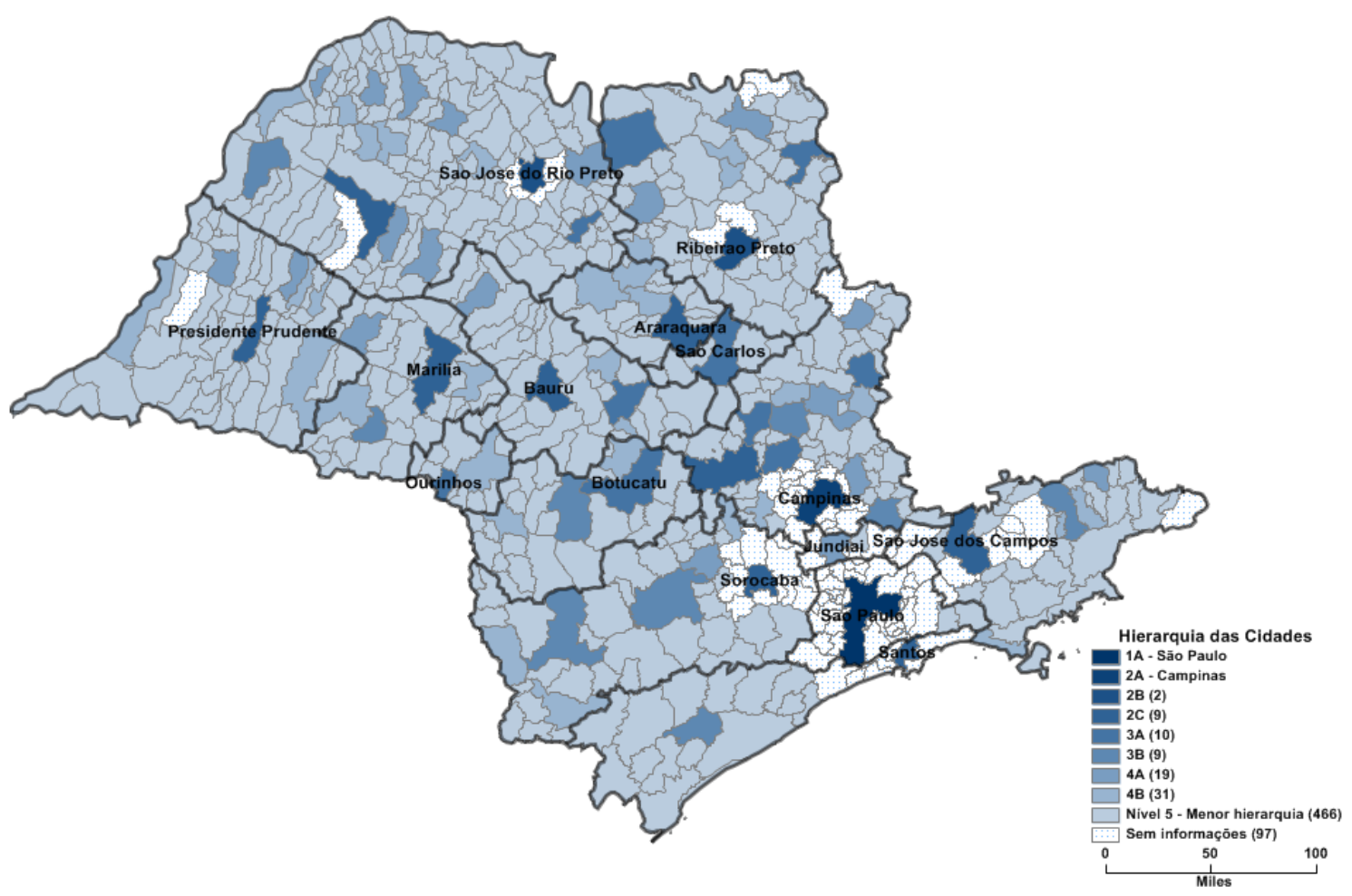

Fontes: Regic-IBGE; Base-shp: CEM/Cebrap. Elaboração Própria. 


\section{Anexo 3 - Número de candidatos alocados na lista por partido e por região de acordo com local de filiação}

Alocação de Candidatos na Lista de acordo com local de filiação dos candidatos - PMDB

\begin{tabular}{|c|c|c|c|c|c|c|c|c|c|c|c|c|c|c|c|c|c|}
\hline \multirow[b]{2}{*}{ Ano } & \multirow[b]{2}{*}{ Partido } & \multicolumn{16}{|c|}{ Região } \\
\hline & & Araraquara & Bauru & Botucatu & Campinas & Jundiaí & Marilía & Ourinhos & $\begin{array}{l}\text { Presidente } \\
\text { Prudente }\end{array}$ & $\begin{array}{c}\text { Ribeirão } \\
\text { Preto }\end{array}$ & RMSP & Santos & $\begin{array}{l}\text { São } \\
\text { Carlos }\end{array}$ & $\begin{array}{c}\text { São } \\
\text { José do } \\
\text { Rio } \\
\text { Preto } \\
\end{array}$ & $\begin{array}{c}\text { São } \\
\text { José } \\
\text { dos } \\
\text { Campos } \\
\end{array}$ & Sorocaba & $\begin{array}{c}\text { Outras } \\
\text { UFs }\end{array}$ \\
\hline 2002 & \multirow{4}{*}{ PMDB } & 1 & - & 1 & 3 & 1 & 1 & - & 1 & - & 18 & - & 1 & 2 & 1 & 4 & 2 \\
\hline 2006 & & - & 3 & - & 1 & 1 & - & - & 1 & - & 24 & 2 & - & 2 & 3 & 1 & 1 \\
\hline 2010 & & - & 2 & 1 & 9 & - & - & - & 1 & 3 & 39 & 3 & - & 1 & 3 & 5 & 1 \\
\hline 2014 & & - & 2 & - & 9 & 1 & 1 & - & 1 & 2 & 66 & - & 1 & 2 & 3 & 2 & - \\
\hline
\end{tabular}

Alocação de Candidatos na Lista de acordo com local de filiação dos candidatos - PT

\begin{tabular}{|c|c|c|c|c|c|c|c|c|c|c|c|c|c|c|c|c|c|}
\hline \multirow[b]{2}{*}{ Ano } & \multirow[b]{2}{*}{ Partido } & \multicolumn{16}{|c|}{ Região } \\
\hline & & Araraquara & Bauru & Botucatu & Campinas & Jundiaí & Marilía & Ourinhos & $\begin{array}{l}\text { Presidente } \\
\text { Prudente }\end{array}$ & $\begin{array}{l}\text { Ribeirão } \\
\text { Preto }\end{array}$ & RMSP & Santos & $\begin{array}{c}\text { São } \\
\text { Carlos }\end{array}$ & $\begin{array}{c}\text { São } \\
\text { José do } \\
\text { Rio } \\
\text { Preto }\end{array}$ & $\begin{array}{c}\text { São } \\
\text { José } \\
\text { dos } \\
\text { Campos }\end{array}$ & Sorocaba & $\begin{array}{c}\text { Outras } \\
\text { UFs }\end{array}$ \\
\hline 2002 & \multirow{4}{*}{ PT } & - & 1 & - & 14 & 1 & - & - & - & 4 & 29 & 2 & 1 & 2 & 3 & 1 & 2 \\
\hline 2006 & & - & 1 & - & 9 & 1 & - & - & 1 & 2 & 32 & 2 & - & 2 & 4 & 3 & 3 \\
\hline 2010 & & - & 1 & 1 & 10 & 2 & - & - & - & 1 & 35 & 5 & 1 & 4 & 2 & 1 & - \\
\hline 2014 & & 1 & 1 & 2 & 9 & 1 & 1 & - & 1 & 1 & 41 & 2 & 1 & 1 & 4 & 1 & 1 \\
\hline
\end{tabular}




\begin{tabular}{|c|c|c|c|c|c|c|c|c|c|c|c|c|c|c|c|c|c|}
\hline \multirow[b]{2}{*}{ Ano } & \multirow[b]{2}{*}{ Partido } & \multicolumn{16}{|c|}{ Região } \\
\hline & & Araraquara & Bauru & Botucatu & Campinas & Jundiaí & Marilía & Ourinhos & $\begin{array}{l}\text { Presidente } \\
\text { Prudente }\end{array}$ & $\begin{array}{c}\text { Ribeirão } \\
\text { Preto }\end{array}$ & RMSP & Santos & $\begin{array}{c}\text { São } \\
\text { Carlos }\end{array}$ & $\begin{array}{c}\text { São } \\
\text { José do } \\
\text { Rio } \\
\text { Preto } \\
\end{array}$ & $\begin{array}{c}\text { São } \\
\text { José } \\
\text { dos } \\
\text { Campos }\end{array}$ & Sorocaba & $\begin{array}{c}\text { Outras } \\
\text { UFs }\end{array}$ \\
\hline 2002 & \multirow{4}{*}{ PPB/PP } & - & - & 2 & 4 & - & - & - & 2 & 1 & 17 & 2 & - & 3 & 3 & 3 & - \\
\hline 2006 & & - & - & - & 3 & 1 & 1 & - & 1 & - & 23 & 1 & - & 3 & 1 & 1 & 2 \\
\hline 2010 & & - & 1 & 2 & 8 & 1 & 2 & - & 2 & 2 & 35 & 5 & - & 5 & 5 & 3 & - \\
\hline 2014 & & - & 1 & - & 4 & - & - & - & - & 2 & 8 & - & - & 1 & - & 3 & - \\
\hline \multicolumn{18}{|c|}{ Alocação de Candidatos na Lista de acordo com local de filiação dos candidatos - PFL/DEM } \\
\hline \multicolumn{18}{|c|}{ Região } \\
\hline Ano & Partido & Araraquara & Bauru & Botucatu & Campinas & Jundiaí & Marilía & Ourinhos & $\begin{array}{l}\text { Presidente } \\
\text { Prudente }\end{array}$ & $\begin{array}{c}\text { Ribeirão } \\
\text { Preto }\end{array}$ & RMSP & Santos & $\begin{array}{c}\text { São } \\
\text { Carlos }\end{array}$ & $\begin{array}{c}\text { São } \\
\text { José do } \\
\text { Rio } \\
\text { Preto } \\
\end{array}$ & $\begin{array}{c}\text { São } \\
\text { José } \\
\text { dos } \\
\text { Campos }\end{array}$ & Sorocaba & $\begin{array}{c}\text { Outras } \\
\text { UFs }\end{array}$ \\
\hline 2002 & & - & 1 & - & 3 & - & - & - & - & 1 & 13 & - & - & - & 1 & - & 4 \\
\hline 2006 & PFL/DEM & 2 & 2 & 1 & 4 & 1 & 1 & - & - & 2 & 18 & 1 & - & 1 & 4 & 1 & 1 \\
\hline 2010 & & - & - & 1 & 2 & - & - & - & - & 1 & 18 & 1 & 1 & 2 & 2 & 2 & - \\
\hline
\end{tabular}

Alocação de Candidatos na Lista de acordo com local de filiação dos candidatos - PSDB

\begin{tabular}{|c|c|c|c|c|c|c|c|c|c|c|c|c|c|c|c|c|c|}
\hline \multirow[b]{2}{*}{ Ano } & \multirow[b]{2}{*}{ Partido } & \multicolumn{16}{|c|}{ Região } \\
\hline & & Araraquara & Bauru & Botucatu & Campinas & Jundiaí & Marilía & Ourinhos & $\begin{array}{l}\text { Presidente } \\
\text { Prudente }\end{array}$ & $\begin{array}{c}\text { Ribeirão } \\
\text { Preto }\end{array}$ & RMSP & Santos & $\begin{array}{c}\begin{array}{c}\text { São } \\
\text { Carlos }\end{array} \\
\end{array}$ & $\begin{array}{c}\text { São } \\
\text { José do } \\
\text { Rio } \\
\text { Preto } \\
\end{array}$ & $\begin{array}{c}\text { São } \\
\text { José } \\
\text { dos } \\
\text { Campos } \\
\end{array}$ & Sorocaba & $\begin{array}{c}\text { Outras } \\
\text { UFs }\end{array}$ \\
\hline 2002 & \multirow{4}{*}{ PSDB } & - & 1 & - & 7 & 2 & 1 & - & - & 3 & 19 & 1 & 1 & 2 & 2 & 1 & 3 \\
\hline 2006 & & - & - & - & 11 & 2 & 3 & - & 1 & 2 & 40 & 5 & 1 & 1 & 2 & 4 & 3 \\
\hline 2010 & & - & 1 & - & 7 & - & - & - & 1 & 2 & 31 & 2 & 1 & 1 & 2 & 2 & - \\
\hline 2014 & & - & 1 & - & 6 & 1 & - & - & 1 & 2 & 34 & 2 & 1 & 1 & 2 & 7 & 1 \\
\hline
\end{tabular}


Alocação de Candidatos na Lista de acordo com local de filiação dos candidatos - PSD

\begin{tabular}{|c|c|c|c|c|c|c|c|c|c|c|c|c|c|c|c|c|c|}
\hline \multirow[b]{2}{*}{ Ano } & \multirow[b]{2}{*}{ Partido } & \multicolumn{16}{|c|}{ Região } \\
\hline & & Araraquara & Bauru & Botucatu & Campinas & Jundiaí & Marilía & Ourinhos & $\begin{array}{l}\text { Presidente } \\
\text { Prudente }\end{array}$ & $\begin{array}{c}\text { Ribeirão } \\
\text { Preto }\end{array}$ & RMSP & Santos & $\begin{array}{c}\text { São } \\
\text { Carlos }\end{array}$ & $\begin{array}{c}\text { São } \\
\text { José do } \\
\text { Rio } \\
\text { Preto } \\
\end{array}$ & $\begin{array}{c}\text { São } \\
\text { José } \\
\text { dos } \\
\text { Campos }\end{array}$ & Sorocaba & $\begin{array}{c}\text { Outras } \\
\text { UFs }\end{array}$ \\
\hline 2014 & PSD & - & - & - & 2 & - & 2 & - & - & - & 16 & - & - & - & 1 & 2 & - \\
\hline
\end{tabular}


Anexo 4 - Número de candidatos alocados na lista por partido e por região de acordo com passado político local

Alocação de Candidatos com Passado Político Local por região - PMDB

\begin{tabular}{|c|c|c|c|c|c|c|c|c|c|c|c|c|c|c|c|c|}
\hline \multirow[b]{2}{*}{ Ano } & \multirow[b]{2}{*}{ Partido } & \multicolumn{15}{|c|}{ Região } \\
\hline & & Araraquara & Bauru & Botucatu & Campinas & Jundiaí & Marilía & Ourinhos & $\begin{array}{l}\text { Presidente } \\
\text { Prudente }\end{array}$ & $\begin{array}{l}\text { Ribeirão } \\
\text { Preto }\end{array}$ & RMSP & Santos & $\begin{array}{c}\text { São } \\
\text { Carlos }\end{array}$ & $\begin{array}{c}\text { São José } \\
\text { do Rio } \\
\text { Preto }\end{array}$ & $\begin{array}{c}\text { São José } \\
\text { dos } \\
\text { Campos }\end{array}$ & Sorocaba \\
\hline 2002 & \multirow{4}{*}{ PMDB } & 1 & - & - & 2 & - & 1 & - & - & - & 4 & - & - & - & - & - \\
\hline 2006 & & - & 4 & - & - & 2 & - & - & - & - & 14 & 3 & - & - & 2 & 2 \\
\hline 2010 & & - & 1 & 1 & 7 & - & - & - & - & 7 & 26 & 3 & - & 4 & 5 & 4 \\
\hline 2014 & & - & 6 & - & 12 & 1 & - & - & 1 & 3 & 71 & - & - & 5 & 9 & 5 \\
\hline \multicolumn{17}{|c|}{ Alocação de Candidatos com Passado Político Local por região - PSDB } \\
\hline & & \multicolumn{15}{|c|}{$\begin{array}{ll}\text { Região } \\
\end{array}$} \\
\hline Ano & Partido & Araraquara & Bauru & Botucatu & Campinas & Jundiaí & Marilía & Ourinhos & $\begin{array}{l}\text { Presidente } \\
\text { Prudente }\end{array}$ & $\begin{array}{l}\text { Ribeirão } \\
\text { Preto }\end{array}$ & RMSP & Santos & $\begin{array}{c}\text { São } \\
\text { Carlos }\end{array}$ & $\begin{array}{l}\text { São José } \\
\text { do Rio } \\
\text { Preto }\end{array}$ & $\begin{array}{c}\text { São José } \\
\text { dos } \\
\text { Campos }\end{array}$ & Sorocaba \\
\hline 2002 & \multirow{4}{*}{ PSDB } & - & - & - & 5 & - & - & - & - & 1 & 3 & - & - & - & 1 & - \\
\hline 2006 & & - & - & - & 12 & 2 & 2 & - & 2 & 3 & 22 & - & - & 1 & 3 & 4 \\
\hline 2010 & & - & - & - & 8 & 5 & - & - & - & 1 & 28 & 3 & - & - & 3 & 1 \\
\hline 2014 & & - & 4 & - & 10 & 3 & - & - & 5 & 7 & 26 & 6 & - & - & 6 & 17 \\
\hline
\end{tabular}

Alocação de Candidatos com Passado Político Local por região - PT

\begin{tabular}{|c|c|c|c|c|c|c|c|c|c|c|c|c|c|c|c|c|}
\hline \multirow[b]{2}{*}{ Ano } & \multirow[b]{2}{*}{ Partido } & \multicolumn{15}{|c|}{ Região } \\
\hline & & Araraquara & Bauru & Botucatu & Campinas & Jundiaí & Marilía & Ourinhos & $\begin{array}{c}\text { Presidente } \\
\text { Prudente }\end{array}$ & $\begin{array}{c}\text { Ribeirão } \\
\text { Preto }\end{array}$ & RMSP & Santos & $\begin{array}{c}\text { São } \\
\text { Carlos }\end{array}$ & $\begin{array}{c}\text { São José } \\
\text { do Rio } \\
\text { Preto }\end{array}$ & $\begin{array}{c}\text { São José } \\
\text { dos } \\
\text { Campos }\end{array}$ & Sorocaba \\
\hline 2002 & \multirow{4}{*}{ PT } & - & 1 & - & 10 & 1 & - & - & - & 2 & 13 & 4 & 1 & 2 & 1 & - \\
\hline 2006 & & - & 2 & - & 11 & 1 & - & - & 2 & 2 & 20 & 8 & - & 5 & 4 & 4 \\
\hline 2010 & & - & 3 & 1 & 12 & 4 & - & - & - & 1 & 36 & 8 & 2 & 3 & 2 & 1 \\
\hline 2014 & & 4 & 5 & 3 & 17 & 4 & - & - & 5 & 1 & 69 & 6 & 2 & 1 & 7 & 7 \\
\hline
\end{tabular}


Alocação de Candidatos com Passado Político Local por região - PFL/DEM

\begin{tabular}{|c|c|c|c|c|c|c|c|c|c|c|c|c|c|c|c|c|}
\hline \multirow[b]{2}{*}{ Ano } & \multirow[b]{2}{*}{ Partido } & \multicolumn{15}{|c|}{ Região } \\
\hline & & Araraquara & Bauru & Botucatu & Campinas & Jundiaí & Marilía & Ourinhos & $\begin{array}{c}\text { Presidente } \\
\text { Prudente }\end{array}$ & $\begin{array}{c}\text { Ribeirão } \\
\text { Preto }\end{array}$ & RMSP & Santos & $\begin{array}{c}\text { São } \\
\text { Carlos }\end{array}$ & $\begin{array}{c}\text { São José } \\
\text { do Rio } \\
\text { Preto }\end{array}$ & $\begin{array}{c}\text { São José } \\
\text { dos } \\
\text { Campos }\end{array}$ & Sorocaba \\
\hline 2002 & & - & 1 & - & 1 & - & - & - & - & - & 3 & - & - & - & 1 & - \\
\hline 2006 & PFL/DEM & 1 & 2 & - & 3 & 2 & - & - & - & - & 4 & 1 & - & 1 & 5 & 1 \\
\hline 2010 & & - & - & - & 2 & - & - & - & - & 1 & 7 & 2 & 1 & 1 & - & 7 \\
\hline
\end{tabular}

Alocação de Candidatos com Passado Político Local por região - PPB/PP

\begin{tabular}{|c|c|c|c|c|c|c|c|c|c|c|c|c|c|c|c|c|}
\hline \multirow[b]{2}{*}{ Ano } & \multirow[b]{2}{*}{ Partido } & \multicolumn{15}{|c|}{ Região } \\
\hline & & Araraquara & Bauru & Botucatu & Campinas & Jundiaí & Marilía & Ourinhos & $\begin{array}{c}\text { Presidente } \\
\text { Prudente }\end{array}$ & $\begin{array}{c}\text { Ribeirão } \\
\text { Preto }\end{array}$ & RMSP & Santos & $\begin{array}{c}\text { São } \\
\text { Carlos }\end{array}$ & $\begin{array}{l}\text { São José } \\
\text { do Rio } \\
\text { Preto }\end{array}$ & $\begin{array}{c}\text { São José } \\
\text { dos } \\
\text { Campos }\end{array}$ & Sorocaba \\
\hline 2002 & \multirow{4}{*}{ PPB/PP } & - & 1 & 1 & 4 & - & - & - & 1 & 1 & 8 & 1 & - & 2 & 1 & 2 \\
\hline 2006 & & - & - & - & 2 & - & 1 & - & 1 & - & 15 & 2 & - & 4 & 1 & 1 \\
\hline 2010 & & - & 2 & 4 & 11 & - & 3 & - & 2 & 6 & 32 & 9 & - & 6 & 9 & 4 \\
\hline 2014 & & - & 5 & - & 8 & - & 1 & - & - & 9 & 20 & - & - & 5 & - & 4 \\
\hline
\end{tabular}

Alocação de Candidatos com Passado Político Local por região - PSD

\begin{tabular}{|c|c|c|c|c|c|c|c|c|c|c|c|c|c|c|c|c|}
\hline \multirow[b]{2}{*}{ Ano } & \multirow[b]{2}{*}{ Partido } & \multicolumn{15}{|c|}{ Região } \\
\hline & & Araraquara & Bauru & Botucatu & Campinas & Jundiaí & Marilía & Ourinhos & $\begin{array}{c}\text { Presidente } \\
\text { Prudente }\end{array}$ & $\begin{array}{c}\text { Ribeirão } \\
\text { Preto }\end{array}$ & RMSP & Santos & $\begin{array}{c}\text { São } \\
\text { Carlos }\end{array}$ & $\begin{array}{c}\text { São José } \\
\text { do Rio } \\
\text { Preto }\end{array}$ & $\begin{array}{c}\text { São José } \\
\text { dos } \\
\text { Campos }\end{array}$ & Sorocaba \\
\hline 2014 & PSD & - & - & - & 3 & - & 2 & - & - & - & 30 & - & - & - & - & 5 \\
\hline
\end{tabular}

Fonte: TSE. Elaboração Própria. 


\section{Anexo 5 - Regic: fluxo informacional e fluxo de pessoas}

O fluxo informacional que atinge os eleitores é tomado neste trabalho como proxy do fluxo de circulação de jornais. A distribuição dos jornais locais funcionam não apenas como meios de informações sobre fatos, mas como instrumento de divulgação de campanha, divulgação da imagem dos políticos, tanto como candidatos, como "figuras conhecidas" da cidade ou da região. A ilustração do fluxo informacional entre as cidades do estado de São Paulo foram divididas de duas formas. A primeira ilustra todos os jornais locais, com exceção dos que se originam na cidade de São Paulo, já a segunda os inclui.

\section{Mapa 17 - O fluxo de informacional: distribuição de jornais locais no estado de}

\section{São Paulo}
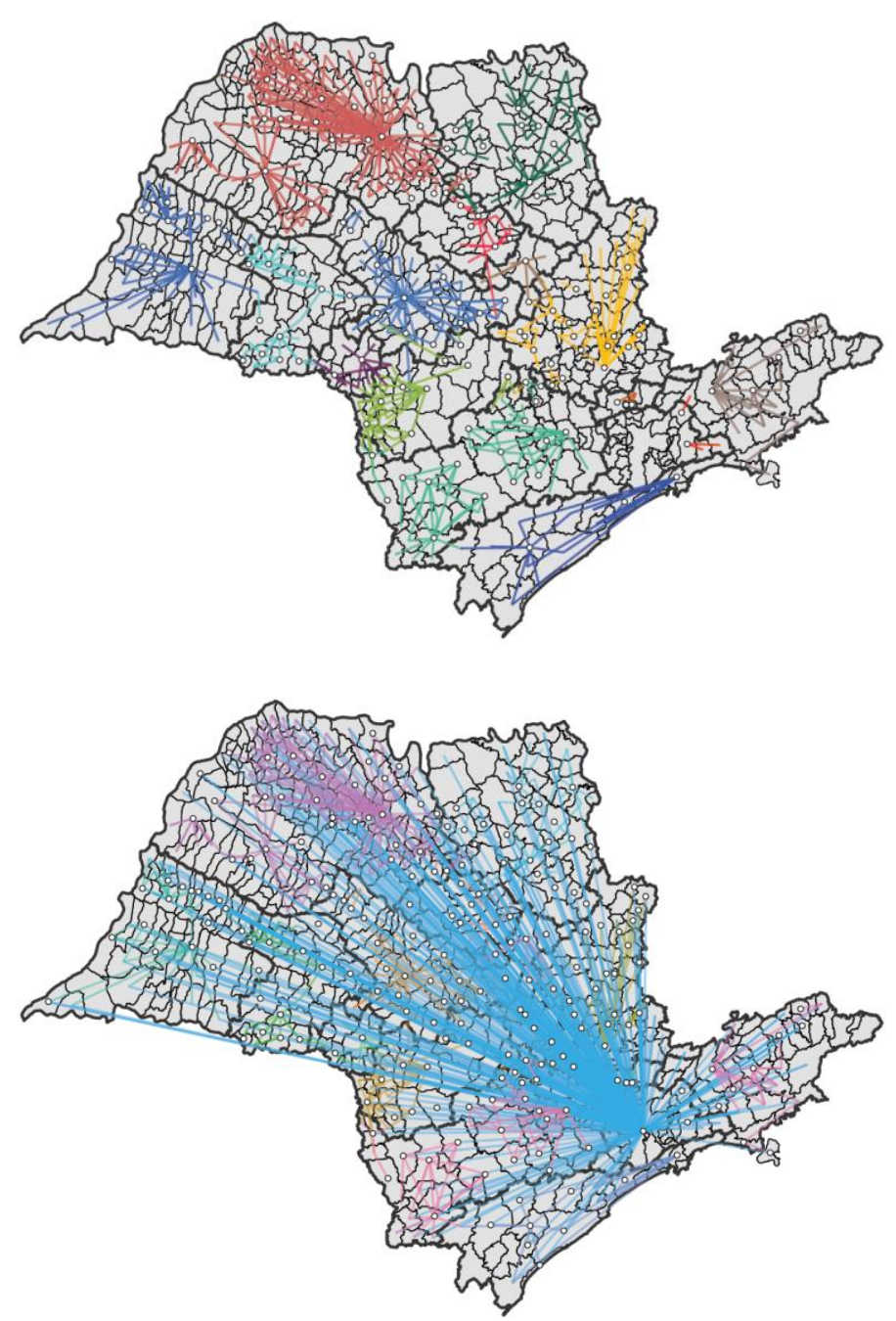

Fontes: Regic-IBGE; Base-shp: CEM/Cebrap. Elaboração Própria. 
O mapa 16 facilita a ilustração do fenômeno tratado no capítulo 3, a saber, a facilidade de extrapolação informacional da Grande Metrópole Nacional (São Paulo) sobre as demais regiões do estado.

Analogamente, o fluxo de pessoas, tomado como o fluxo de transportes diários entre os cidadãos do estado, revela o caminho percorrido diariamente pelos habitantes de uma região. Os deslocamentos caracterizam o fluxo de pessoas que diariamente se locomove para estudar em outras cidades, fazer compras, utilizar demais serviços, como saúde. Ele revela quais são os destinos que os habitantes de uma região tomam diariamente em busca de uma rede social e econômica a qual depende e caracteriza a vida dessas pessoas. Como anteriormente, o fluxo de pessoas foi tomado primeiramente sem a cidade de São Paulo e, depois, incluindo-a.

\section{Mapa 18 - O fluxo de pessoas: o fluxo de transporte entre cidades em SP}

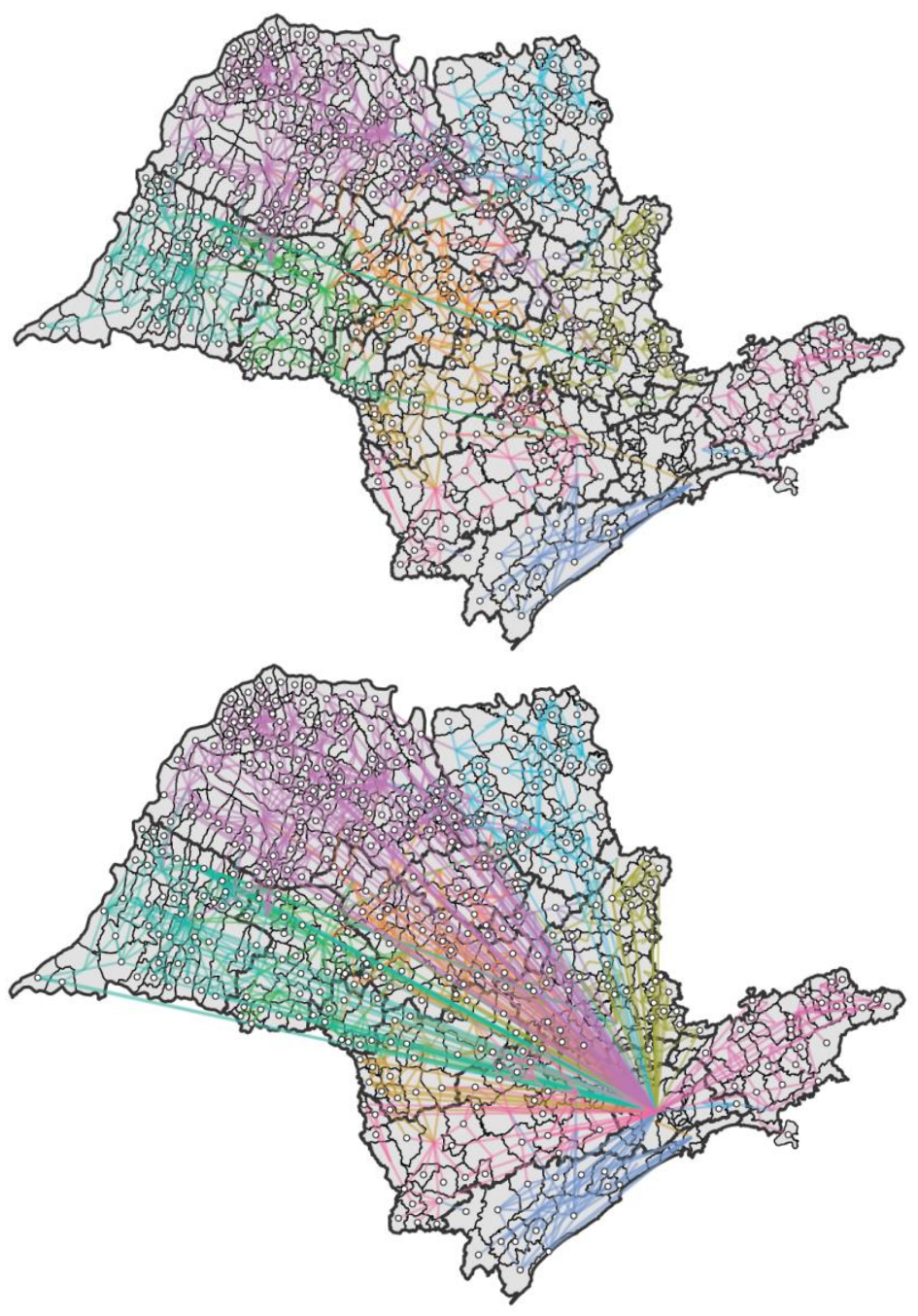

Fontes: Regic-IBGE; Base-shp: CEM/Cebrap. Elaboração Própria. 
Da mesma forma, o fluxo de pessoas revela a intensidade de relações entre São Paulo e as demais regiões do estado. Tal característica não implica na diminuição da importância das regiões de nível hierárquico inferior, mas estabelece que tanto informações geradas (mapa 16) quanto o fluxo de pessoas (mapa 17) com a cidade de São Paulo tem maior intensidade, ocorre com mais facilidade entre as regiões. Vale ressaltar que o contrário, como evidenciam os mapas, não é verdadeiro: regiões distantes não influenciam São Paulo, da mesma forma que não influenciam outras regiões de nível hierárquico semelhante. 


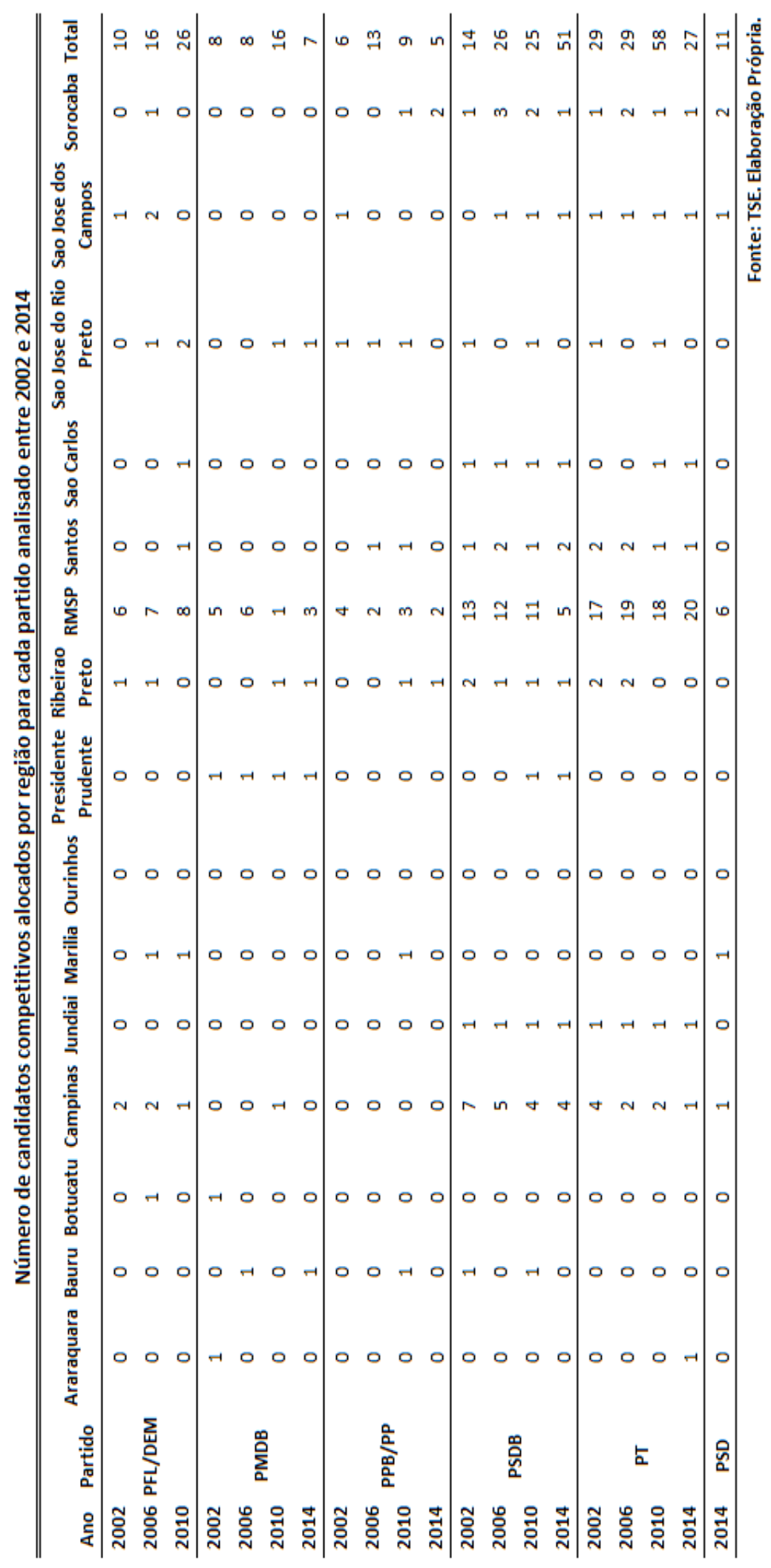




\section{Anexo 7 - Região do candidato de acordo com a sua posição na lista do partido por região}

\section{1 - PFL/DEM}

Alocação regional dos candidatos na lista por região e posição na lista (votos) - PFL/DEM 2002

\begin{tabular}{|c|c|c|c|c|c|c|c|c|c|c|c|c|c|c|c|}
\hline $\begin{array}{l}\text { Posição } \\
\text { na lista }\end{array}$ & Araraquara & Bauru & Botucatu & Campinas & Jundiai & Marilia & Ourinhos & $\begin{array}{c}\text { Presidente } \\
\text { Prudente } \\
\text { (Pres.Prudte.) }\end{array}$ & $\begin{array}{l}\text { Ribeirao Preto } \\
\text { (Rib. Preto) }\end{array}$ & RMSP & Santos & São Carlos & $\begin{array}{c}\text { Sao Jose do } \\
\text { Rio Preto } \\
\text { (SJRP) } \\
\end{array}$ & $\begin{array}{l}\text { São José dos } \\
\text { Campos (SJC) }\end{array}$ & Sorocaba \\
\hline 1 & Rib. Preto & RMSP & RMSP & Campinas & Campinas & Campinas & RMSP & RMSP & Rib. Preto & RMSP & RMSP & Campinas & RMSP & SJC & RMSP \\
\hline 2 & Campinas & RMSP & RMSP & Campinas & RMSP & RMSP & Campinas & RMSP & Campinas & RMSP & RMSP & RMSP & RMSP & RMSP & RMSP \\
\hline 3 & Campinas & RMSP & Campinas & RMSP & RMSP & RMSP & RMSP & Campinas & RMSP & RMSP & Rib. Preto & Rib. Preto & Campinas & Campinas & Campinas \\
\hline 4 & RMSP & Campinas & RMSP & RMSP & RMSP & RMSP & RMSP & RMSP & RMSP & RMSP & RMSP & RMSP & RMSP & RMSP & RMSP \\
\hline 5 & RMSP & RMSP & Campinas & RMSP & RMSP & RMSP & RMSP & RMSP & RMSP & RMSP & RMSP & RMSP & RMSP & RMSP & RMSP \\
\hline 6 & RMSP & Campinas & RMSP & Rib. Preto & RMSP & RMSP & RMSP & RMSP & Campinas & Campinas & Campinas & Campinas & Campinas & RMSP & RMSP \\
\hline 7 & RMSP & RMSP & RMSP & RMSP & Campinas & Campinas & Campinas & Campinas & RMSP & RMSP & RMSP & RMSP & Rib. Preto & RMSP & RMSP \\
\hline 8 & RMSP & Rib. Preto & RMSP & RMSP & Rib. Preto & Rib. Preto & RMSP & RMSP & RMSP & Campinas & RMSP & RMSP & RMSP & Rib. Preto & Campinas \\
\hline 9 & RMSP & RMSP & Rib. Preto & SJC & SJC & SJC & Rib. Preto & Rib. Preto & SJC & Rib. Preto & Campinas & RMSP & RMSP & Campinas & Rib. Preto \\
\hline 10 & SJC & SJC & SJC & RMSP & RMSP & RMSP & SJC & SJC & RMSP & SJC & SJC & SJC & SJC & RMSP & SJC \\
\hline
\end{tabular}


Alocação regional dos candidatos na lista por região e posição na lista (votos) - PFL/DEM 2006

\begin{tabular}{|c|c|c|c|c|c|c|c|c|c|c|c|c|c|c|c|}
\hline $\begin{array}{l}\text { Posição } \\
\text { na lista }\end{array}$ & Araraquara & Bauru & Botucatu & Campinas & Jundiai & Marilia & Ourinhos & $\begin{array}{c}\text { Presidente } \\
\text { Prudente } \\
\text { (Pres.Prudte.) }\end{array}$ & $\begin{array}{c}\text { Ribeirao } \\
\text { Preto (Rib. } \\
\text { Preto) } \\
\end{array}$ & RMSP & Santos & São Carlos & $\begin{array}{c}\text { Sao Jose do } \\
\text { Rio Preto } \\
\text { (SJRP) } \\
\end{array}$ & $\begin{array}{l}\text { São José dos } \\
\text { Campos (SJC) }\end{array}$ & Sorocaba \\
\hline 1 & RMSP & Campinas & Botucatu & Campinas & Campinas & Campinas & Marilia & RMSP & RMSP & RMSP & Marilia & RMSP & SJRP & SJC & Sorocaba \\
\hline 2 & Campinas & RMSP & RMSP & RMSP & RMSP & RMSP & Rib.Preto & SJRP & SJC & RMSP & RMSP & Campinas & RMSP & RMSP & SJRP \\
\hline 3 & Campinas & SJRP & RMSP & RMSP & RMSP & RMSP & RMSP & Rib.Preto & Rib.Preto & Sorocaba & RMSP & Rib.Preto & SJC & RMSP & RMSP \\
\hline 4 & Rib.Preto & RMSP & SJRP & RMSP & Sorocaba & Sorocaba & RMSP & RMSP & Campinas & RMSP & Sorocaba & Sorocaba & RMSP & RMSP & RMSP \\
\hline 5 & Marilia & Botucatu & Rib.Preto & Campinas & RMSP & RMSP & RMSP & Marilia & SJRP & Marilia & SJC & RMSP & Rib.Preto & Sorocaba & RMSP \\
\hline 6 & RMSP & Rib.Preto & RMSP & RMSP & RMSP & RMSP & Campinas & Botucatu & RMSP & RMSP & RMSP & Campinas & Marilia & Rib.Preto & Marilia \\
\hline 7 & RMSP & RMSP & Sorocaba & RMSP & RMSP & RMSP & SJRP & Campinas & Campinas & SJC & RMSP & RMSP & Campinas & RMSP & Rib.Preto \\
\hline 8 & RMSP & Marilia & SJC & SJC & Marilia & Marilia & Botucatu & RMSP & RMSP & RMSP & Campinas & RMSP & Botucatu & Campinas & RMSP \\
\hline 9 & SJRP & RMSP & Marilia & SJRP & Rib.Preto & Rib.Preto & RMSP & RMSP & RMSP & RMSP & RMSP & RMSP & Campinas & RMSP & Campinas \\
\hline 10 & RMSP & Campinas & RMSP & Rib.Preto & Campinas & Campinas & RMSP & Sorocaba & Botucatu & Campinas & Botucatu & Marilia & RMSP & RMSP & RMSP \\
\hline 11 & Botucatu & SJC & RMSP & Botucatu & SJRP & SJRP & Sorocaba & SJC & RMSP & RMSP & SJRP & RMSP & RMSP & Marilia & SJC \\
\hline 12 & RMSP & RMSP & Campinas & Sorocaba & Botucatu & Botucatu & Campinas & RMSP & Marilia & Campinas & Rib.Preto & Botucatu & RMSP & Botucatu & Campinas \\
\hline 13 & Sorocaba & RMSP & Campinas & Marilia & RMSP & RMSP & RMSP & RMSP & RMSP & SJRP & RMSP & SJC & RMSP & Campinas & Botucatu \\
\hline 14 & SJC & Sorocaba & RMSP & RMSP & SJC & SJC & SJC & RMSP & Sorocaba & Rib.Preto & RMSP & SJRP & Sorocaba & SJRP & RMSP \\
\hline 15 & RMSP & RMSP & SJC & RMSP & RMSP & RMSP & RMSP & SJC & RMSP & SJC & Campinas & RMSP & RMSP & SJC & RMSP \\
\hline 16 & SJC & SJC & RMSP & SJC & SJC & SJC & SJC & Campinas & SJC & Botucatu & SJC & SJC & SJC & RMSP & SJC \\
\hline
\end{tabular}

Fonte: TSE. Elaboração Própria. 
Alocação regional dos candidatos na lista por região e posição na lista (votos) - PFL/DEM 2010

\begin{tabular}{|c|c|c|c|c|c|c|c|c|c|c|c|c|c|c|c|}
\hline $\begin{array}{l}\text { Posição na } \\
\text { lista }\end{array}$ & Araraquara & Bauru & Botucatu & Campinas & Jundiai & Marilia & Ourinhos & $\begin{array}{c}\text { Presidente } \\
\text { Prudente } \\
\text { (Pres.Prudte.) }\end{array}$ & $\begin{array}{c}\text { Ribeirao } \\
\text { Preto (Rib. } \\
\text { Preto) }\end{array}$ & RMSP & Santos & São Carlos & $\begin{array}{l}\text { Sao Jose do } \\
\text { Rio Preto } \\
\text { (SJRP) }\end{array}$ & $\begin{array}{c}\text { São José } \\
\text { dos Campos } \\
\text { (SJC) }\end{array}$ & Sorocaba \\
\hline 2 & RMSP & RMSP & RMSP & RMSP & RMSP & SJRP & RMSP & SJRP & Campinas & RMSP & RMSP & SJRP & SJRP & RMSP & RMSP \\
\hline 3 & Sao Carlos & Campinas & RMSP & RMSP & RMSP & RMSP & SJRP & RMSP & SJRP & RMSP & Marilia & RMSP & RMSP & RMSP & RMSP \\
\hline 4 & RMSP & RMSP & SJRP & Sao Carlos & RMSP & RMSP & RMSP & SJRP & RMSP & SJRP & RMSP & RMSP & RMSP & RMSP & RMSP \\
\hline 5 & RMSP & Sao Carlos & Sao Carlos & SJRP & RMSP & RMSP & RMSP & RMSP & SJRP & RMSP & RMSP & RMSP & Marilia & RMSP & SJRP \\
\hline 6 & RMSP & SJRP & RMSP & RMSP & RMSP & SJRP & RMSP & Marilia & RMSP & RMSP & RMSP & Campinas & RMSP & RMSP & Marilia \\
\hline 7 & RMSP & Marilia & RMSP & RMSP & Marilia & RMSP & RMSP & RMSP & RMSP & Marilia & RMSP & RMSP & RMSP & SJRP & RMSP \\
\hline 8 & Campinas & RMSP & RMSP & RMSP & RMSP & RMSP & SJRP & Sao Carlos & Sao Carlos & RMSP & SJRP & Marilia & Campinas & Campinas & SJRP \\
\hline 9 & Marilia & RMSP & Marilia & RMSP & SJRP & RMSP & RMSP & RMSP & RMSP & RMSP & RMSP & RMSP & RMSP & RMSP & RMSP \\
\hline 10 & SJRP & RMSP & Campinas & RMSP & RMSP & Sao Carlos & RMSP & RMSP & RMSP & RMSP & RMSP & RMSP & RMSP & RMSP & RMSP \\
\hline 11 & RMSP & RMSP & RMSP & SJRP & RMSP & RMSP & Sao Carlos & RMSP & Marilia & Campinas & RMSP & SJRP & RMSP & SJRP & RMSP \\
\hline 13 & RMSP & RMSP & RMSP & RMSP & Santos & Campinas & Santos & Campinas & RMSP & SJRP & Campinas & Santos & Sao Carlos & Sao Carlos & Sao Carlos \\
\hline 14 & Santos & Santos & Santos & Santos & Sao Carlos & Santos & RMSP & Santos & Santos & Sao Carlos & SJRP & RMSP & Santos & Santos & Santos \\
\hline
\end{tabular}

Fonte: TSE. Elaboração Própria.

\section{$2-\mathrm{PMDB}$}


Alocação regional dos candidatos na lista por região e posição na lista (votos) - PMDB 2002

\begin{tabular}{|c|c|c|c|c|c|c|c|c|c|c|c|c|c|c|c|}
\hline $\begin{array}{l}\text { Posição } \\
\text { na lista }\end{array}$ & Araraquara & Bauru & Botucatu & Campinas & Jundiai & Marilia & Ourinhos & $\begin{array}{c}\text { Presidente } \\
\text { Prudente } \\
\text { (Pres.Prudte.) }\end{array}$ & $\begin{array}{c}\text { Ribeirao } \\
\text { Preto (Rib. } \\
\text { Preto) }\end{array}$ & RMSP & Santos & São Carlos & $\begin{array}{l}\text { Sao Jose do } \\
\text { Rio Preto } \\
\text { (SJRP) }\end{array}$ & $\begin{array}{l}\text { São José } \\
\text { dos } \\
\text { Campos } \\
\text { (SJC) } \\
\end{array}$ & Sorocaba \\
\hline 1 & Araraquara & Botucatu & Botucatu & RMSP & RMSP & RMSP & Botucatu & RMSP & RMSP & RMSP & RMSP & Araraquara & RMSP & RMSP & RMSP \\
\hline 2 & RMSP & RMSP & Pres.Prudte. & RMSP & RMSP & RMSP & RMSP & Pres.Prudte. & RMSP & RMSP & RMSP & RMSP & Pres.Prudte. & RMSP & Botucatu \\
\hline 3 & Botucatu & RMSP & RMSP & RMSP & RMSP & RMSP & Pres.Prudte. & Botucatu & Araraquara & RMSP & RMSP & RMSP & RMSP & RMSP & RMSP \\
\hline 4 & RMSP & Araraquara & RMSP & Botucatu & RMSP & RMSP & RMSP & RMSP & Pres.Prudte. & RMSP & RMSP & RMSP & Araraquara & Araraquara & RMSP \\
\hline 5 & RMSP & Pres.Prudte. & RMSP & RMSP & Pres.Prudte.F & Pres.Prudte. & RMSP & RMSP & RMSP & RMSP & Pres.Prudte. & RMSP & RMSP & RMSP & RMSP \\
\hline 6 & Pres.Prudte. & RMSP & Araraquara & Araraquara & Botucatu & Botucatu & Ara raquara & RMSP & Botucatu & Araraquara & Botucatu & Botucatu & RMSP & Botucatu & RMSP \\
\hline 7 & RMSP & RMSP & RMSP & Pres.Prudte. & RMSP & RMSP & RMSP & Araraquara & RMSP & Botucatu & Araraquara & RMSP & Botucatu & RMSP & Araraquara \\
\hline 8 & RMSP & RMSP & RMSP & RMSP & Araraquara & Araraquara & RMSP & RMSP & RMSP & Pres.Prudte. & RMSP & Pres.Prudte. & RMSP & Pres.Prudte.I & Pres.Prudte. \\
\hline
\end{tabular}

Alocação regional dos candidatos na lista por região e posição na lista (votos) - PMDB 2006

\begin{tabular}{|c|c|c|c|c|c|c|c|c|c|c|c|c|c|c|c|}
\hline $\begin{array}{l}\text { Posição na } \\
\text { lista }\end{array}$ & Araraquara & Bauru & Botucatu & Campinas & Jundiai & Marilia & Ourinhos & $\begin{array}{c}\text { Presidente } \\
\text { Prudente } \\
\text { (Pres.Prudte.) }\end{array}$ & $\begin{array}{c}\text { Ribeirao Preto } \\
\text { (Rib. Preto) }\end{array}$ & RMSP & Santos & São Carlos & $\begin{array}{c}\text { Sao Jose do } \\
\text { Rio Preto } \\
\text { (SJRP) } \\
\end{array}$ & $\begin{array}{l}\text { São José dos } \\
\text { Campos (SJC) }\end{array}$ & Sorocaba \\
\hline 1 & RMSP & Bauru & RMSP & RMSP & RMSP & RMSP & Pres.Prudte & Pres.Prudte & RMSP & RMSP & RMSP & RMSP & RMSP & RMSP & RMSP \\
\hline 2 & RMSP & RMSP & RMSP & RMSP & RMSP & RMSP & RMSP & RMSP & Pres.Prudte & RMSP & RMSP & RMSP & RMSP & RMSP & RMSP \\
\hline 3 & RMSP & RMSP & RMSP & RMSP & RMSP & RMSP & RMSP & RMSP & RMSP & RMSP & RMSP & RMSP & Pres.Prudte & RMSP & RMSP \\
\hline 4 & Pres.Prudte & Pres.Prudte & Pres.Prudte & RMSP & RMSP & RMSP & RMSP & RMSP & RMSP & RMSP & RMSP & RMSP & RMSP & RMSP & RMSP \\
\hline 5 & RMSP & RMSP & RMSP & RMSP & RMSP & RMSP & Bauru & RMSP & RMSP & RMSP & RMSP & RMSP & RMSP & RMSP & RMSP \\
\hline 6 & RMSP & RMSP & RMSP & Pres.Prudte & RMSP & RMSP & RMSP & RMSP & RMSP & RMSP & Pres.Prudte & Pres.Prudte & RMSP & Pres.Prudte & RMSP \\
\hline 7 & RMSP & RMSP & Bauru & RMSP & Pres.Prudte & Pres.Prudte & RMSP & RMSP & RMSP & Pres.Prudte & RMSP & RMSP & RMSP & RMSP & Pres.Prudte \\
\hline 8 & Bauru & RMSP & RMSP & Bauru & Bauru & Bauru & RMSP & Bauru & Bauru & Bauru & Bauru & Bauru & Bauru & Bauru & Bauru \\
\hline
\end{tabular}

Fonte: TSE. Elaboração Própria. 


\begin{tabular}{|c|c|c|c|c|c|c|c|c|c|c|c|c|c|c|c|}
\hline $\begin{array}{l}\text { Posição na } \\
\text { lista }\end{array}$ & Araraquara & Bauru & Botucatu & Campinas & Jundiai & Marilia & Ourinhos & $\begin{array}{l}\text { Presidente } \\
\text { Prudente } \\
\text { (Pres.Prudte.) }\end{array}$ & $\begin{array}{c}\text { Ribeirao Preto } \\
\text { (Rib. Preto) }\end{array}$ & RMSP & Santos & São Carlos & $\begin{array}{l}\text { Sao Jose do } \\
\text { Rio Preto } \\
\text { (SJRP) }\end{array}$ & $\begin{array}{l}\text { São José } \\
\text { dos Campos } \\
\text { (SJC) }\end{array}$ & Sorocaba \\
\hline 1 & Rib. Preto & Pres.Prudte $\mathrm{F}$ & Pres.Prudte & Campinas & Campinas $\mathrm{P}$ & Pres.Prudte $P$ & Pres.Prudte & Pres.Prudte & Rib. Preto & RMSP & Pres.Prudte & Campinas & SJRP & RMSP & Campinas \\
\hline 2 & Pres.Prudte & RMSP & RMSP & Pres.Prudte & Pres.Prudte & RMSP & RMSP & SJRP & Pres.Prudte & Campinas & RMSP & Rib. Preto & Pres.Prudte & Campinas & RMSP \\
\hline 3 & Campinas & SJRP & Campinas & RMSP & RMSP & SJRP & SJRP & RMSP & Campinas & Pres.Prudte & Campinas & Pres.Prudte & Campinas & Pres.Prudte & Pres.Prudte \\
\hline 4 & SJRP & Campinas & Rib. Preto & SJRP & SJRP & Campinas & Campinas & Campinas & SJRP & SJRP & SJRP & RMSP & RMSP & SJRP & SJRP \\
\hline 5 & RMSP & Rib. Preto & SJRP & Rib. Preto & Rib. Preto & Rib. Preto & Rib. Preto & Rib. Preto & RMSP & Rib. Preto & Rib. Preto & SJRP & Rib. Preto & Rib. Preto & Rib. Preto \\
\hline & & & & & & & & & & & & & Fonte & e: TSE. Elabora & ação Própria. \\
\hline \multicolumn{16}{|c|}{ Alocação regional dos candidatos na lista por região e posição na lista (votos) - PMDB 2014} \\
\hline $\begin{array}{l}\text { Posição na } \\
\text { lista }\end{array}$ & Araraquara & Bauru & Botucatu & Campinas & Jundiai & Marilia & Ourinhos & $\begin{array}{c}\text { Presidente } \\
\text { Prudente } \\
\text { (Pres.Prudte.) }\end{array}$ & $\begin{array}{c}\text { Ribeirao } \\
\text { Preto (Rib. } \\
\quad \text { Preto) }\end{array}$ & RMSP & Santos & São Carlos & $\begin{array}{l}\text { Sao Jose do } \\
\text { Rio Preto } \\
\text { (SJRP) }\end{array}$ & $\begin{array}{l}\text { São José } \\
\text { dos Campos } \\
\text { (SJC) }\end{array}$ & Sorocaba \\
\hline 2 & RMSP & Rib. Preto & Bauru & RMSP & Rib. Preto & Rib. Preto & Rib. Preto & RMSP & RMSP & RMSP & RMSP & RMSP & Rib. Preto & RMSP & RMSP \\
\hline 3 & SJRP & RMSP & RMSP & RMSP & RMSP & Pres.Prudte & Bauru & Rib. Preto & SJRP & Rib. Preto & RMSP & RMSP & RMSP & RMSP & RMSP \\
\hline 4 & RMSP & Pres.Prudte & RMSP & Pres.Prudte & RMSP & RMSP & Pres.Prudte & RMSP & RMSP & RMSP & RMSP & SJRP & Pres.Prudte & RMSP & RMSP \\
\hline 5 & Bauru & SJRP & Pres.Prudte & SJRP & SJRP & RMSP & RMSP & SJRP & Pres.Prudte $P$ & Pres.Prudte $\mathrm{F}$ & Pres.Prudte & Pres.Prudte & RMSP & Pres.Prudte & Pres.Prudte \\
\hline 6 & Pres.Prudte & RMSP & RMSP & Bauru & Pres.Prudte & Bauru & RMSP & RMSP & Bauru & SJRP & SJRP & Bauru & Bauru & SJRP & Bauru \\
\hline 7 & RMSP & RMSP & SJRP & RMSP & Bauru & SJRP & SJRP & Bauru & RMSP & Bauru & Bauru & RMSP & RMSP & Bauru & SJRP \\
\hline
\end{tabular}

Fonte: TSE. Elaboração Própria.

\section{3 - PPB/PP}


Alocação regional dos candidatos na lista por região e posição na lista (votos) - PPB/PP 2002

\begin{tabular}{|c|c|c|c|c|c|c|c|c|c|c|c|c|c|c|c|}
\hline $\begin{array}{l}\text { Posição na } \\
\text { lista }\end{array}$ & Araraquara & Bauru & Botucatu & Campinas & Jundiai & Marilia & Ourinhos & $\begin{array}{c}\text { Presidente } \\
\text { Prudente } \\
\text { (Pres.Prudte.) }\end{array}$ & $\begin{array}{c}\text { Ribeirao Preto } \\
\text { (Rib. Preto) }\end{array}$ & RMSP & Santos & São Carlos & $\begin{array}{l}\text { Sao Jose do Rio } \\
\text { Preto (SJRP) }\end{array}$ & $\begin{array}{l}\text { São José dos } \\
\text { Campos (SJC) }\end{array}$ & Sorocaba \\
\hline 1 & RMSP & SJRP & RMSP & RMSP & RMSP & RMSP & RMSP & SJRP & SJRP & RMSP & RMSP & RMSP & SJRP & SJC & RMSP \\
\hline 2 & SJRP & RMSP & RMSP & RMSP & RMSP & RMSP & RMSP & RMSP & RMSP & RMSP & RMSP & RMSP & RMSP & RMSP & RMSP \\
\hline 3 & RMSP & RMSP & RMSP & SJRP & RMSP & RMSP & RMSP & RMSP & RMSP & RMSP & RMSP & RMSP & RMSP & RMSP & RMSP \\
\hline 4 & RMSP & RMSP & RMSP & SJC & RMSP & RMSP & SJRP & RMSP & RMSP & RMSP & RMSP & RMSP & RMSP & RMSP & SJC \\
\hline 5 & RMSP & RMSP & SJRP & RMSP & SJC & SJC & SJC & RMSP & RMSP & SJC & SJC & SJRP & RMSP & RMSP & RMSP \\
\hline 6 & SJC & SJC & SJC & RMSP & SJRP & SJRP & RMSP & SJC & SJC & SJRP & SJRP & SJC & SJC & SJRP & SJRP \\
\hline
\end{tabular}

Alocação regional dos candidatos na lista por região e posição na lista (votos) - PPB/PP 2006

\begin{tabular}{|c|c|c|c|c|c|c|c|c|c|c|c|c|c|c|c|}
\hline $\begin{array}{l}\text { Posição na } \\
\text { lista }\end{array}$ & Araraquara & Bauru & Botucatu & Campinas & Jundiai & Marilia & Ourinhos & $\begin{array}{c}\text { Presidente } \\
\text { Prudente } \\
\text { (Pres.Prudte.) }\end{array}$ & $\begin{array}{c}\text { Ribeirao } \\
\text { Preto (Rib. } \\
\text { Preto) }\end{array}$ & RMSP & Santos & São Carlos & $\begin{array}{l}\text { Sao Jose do } \\
\text { Rio Preto } \\
\text { (SJRP) }\end{array}$ & $\begin{array}{l}\text { São José } \\
\text { dos Campos } \\
\text { (SJC) }\end{array}$ & Sorocaba \\
\hline 2 & RMSP & RMSP & RMSP & RMSP & RMSP & RMSP & RMSP & RMSP & RMSP & RMSP & RMSP & RMSP & RMSP & RMSP & RMSP \\
\hline 3 & SJRP & SJRP & Santos & SJRP & Santos & Santos & SJRP & SJRP & SJRP & SJRP & RMSP & SJRP & RMSP & Santos & SJRP \\
\hline 4 & Santos & Santos & SJRP & Santos & SJRP & SJRP & Santos & Santos & Santos & Santos & SJRP & Santos & Santos & SJRP & Santos \\
\hline
\end{tabular}

Fonte: TSE. Elaboração Própria. 


\begin{tabular}{|c|c|c|c|c|c|c|c|c|c|c|c|c|c|c|c|}
\hline $\begin{array}{l}\text { Posição na } \\
\text { lista }\end{array}$ & Araraquara & Bauru & Botucatu & Campinas & Jundiai & Marilia & Ourinhos & $\begin{array}{c}\text { Presidente } \\
\text { Prudente } \\
\text { (Pres.Prudte.) }\end{array}$ & $\begin{array}{c}\text { Ribeirao } \\
\text { Preto (Rib. } \\
\text { Preto) }\end{array}$ & RMSP & Santos & São Carlos & $\begin{array}{c}\text { Sao Jose do } \\
\text { Rio Preto } \\
\text { (SJRP) }\end{array}$ & $\begin{array}{l}\text { São José } \\
\text { dos Campos } \\
\text { (SJC) }\end{array}$ & Sorocaba \\
\hline 2 & RMSP & RMSP & Sorocaba & RMSP & RMSP & RMSP & RMSP & RMSP & Marilia & RMSP & RMSP & RMSP & RMSP & RMSP & RMSP \\
\hline 3 & RMSP & Marilia & RMSP & RMSP & RMSP & SJRP & Marilia & Marilia & RMSP & RMSP & RMSP & RMSP & RMSP & RMSP & RMSP \\
\hline 4 & SJRP & RMSP & Marilia & SJRP & Santos & RMSP & Bauru & SJRP & RMSP & SJRP & RMSP & SJRP & RMSP & Santos & RMSP \\
\hline 5 & Marilia & RMSP & RMSP & Santos & SJRP & RMSP & SJRP & RMSP & SJRP & Santos & SJRP & Marilia & Marilia & SJRP & Marilia \\
\hline 6 & Bauru & SJRP & SJRP & Marilia & Sorocaba & Bauru & Sorocaba & Bauru & RMSP & Bauru & Sorocaba & Santos & Santos & Marilia & SJRP \\
\hline 7 & Santos & Santos & Bauru & Bauru & Marilia & Santos & RMSP & Santos & Santos & Marilia & Bauru & Bauru & Bauru & Bauru & Santos \\
\hline 8 & Rib. Preto & Sorocaba & Santos & Sorocaba & Bauru & Rib. Preto & Santos & Rib. Preto & Bauru & Sorocaba & Marilia & Rib. Preto & Rib. Preto & Sorocaba & Bauru \\
\hline 9 & Sorocaba & Rib. Preto & Rib. Preto & Rib. Preto & Rib. Preto & Sorocaba & Rib. Preto & Sorocaba & Sorocaba & Rib. Preto & Rib. Preto & Sorocaba & Sorocaba & Rib. Preto & Rib. Preto \\
\hline
\end{tabular}

Alocação regional dos candidatos na lista por região e posição na lista (votos) - PPB/PP 2014

\begin{tabular}{|c|c|c|c|c|c|c|c|c|c|c|c|c|c|c|c|}
\hline $\begin{array}{l}\text { Posição na } \\
\text { lista }\end{array}$ & Araraquara & Bauru & Botucatu & Campinas & Jundiai & Marilia & Ourinhos & $\begin{array}{c}\text { Presidente } \\
\text { Prudente } \\
\text { (Pres.Prudte.) }\end{array}$ & $\begin{array}{c}\text { Ribeirao } \\
\text { Preto (Rib. } \\
\text { Preto) }\end{array}$ & RMSP & Santos & São Carlos & $\begin{array}{l}\text { Sao Jose do } \\
\text { Rio Preto } \\
\text { (SJRP) }\end{array}$ & $\begin{array}{l}\text { São José } \\
\text { dos Campos } \\
\text { (SJC) }\end{array}$ & Sorocaba \\
\hline 1 & RMSP & RMSP & Sorocaba & RMSP & Sorocaba & Sorocaba & RMSP & RMSP & Rib. Preto & RMSP & RMSP & RMSP & Sorocaba & Sorocaba & Sorocaba \\
\hline 2 & Sorocaba & Sorocaba & RMSP & Sorocaba & RMSP & RMSP & Sorocaba & Sorocaba & Sorocaba & Sorocaba & Sorocaba & Sorocaba & RMSP & RMSP & Sorocaba \\
\hline 3 & Sorocaba & Sorocaba & Sorocaba & Sorocaba & RMSP & Sorocaba & RMSP & RMSP & RMSP & Sorocaba & Sorocaba & RMSP & RMSP & RMSP & RMSP \\
\hline 4 & RMSP & RMSP & RMSP & RMSP & Sorocaba & RMSP & Sorocaba & Sorocaba & Sorocaba & RMSP & RMSP & Sorocaba & Sorocaba & Sorocaba & RMSP \\
\hline
\end{tabular}

Fonte: TSE. Elaboração Própria.

\section{4 - PSDB}


Alocação regional dos candidatos na lista por região e posição na lista (votos) - PSDB 2002

\begin{tabular}{|c|c|c|c|c|c|c|c|c|c|c|c|c|c|c|c|}
\hline $\begin{array}{l}\text { Posição } \\
\text { na lista }\end{array}$ & Araraquara & Bauru & Botucatu & Campinas & Jundiai & Marilia & Ourinhos & $\begin{array}{c}\text { Presidente } \\
\text { Prudente } \\
\text { (Pres.Prudte.) }\end{array}$ & $\begin{array}{l}\text { Ribeirao Preto } \\
\text { (Rib. Preto) }\end{array}$ & RMSP & Santos & São Carlos & $\begin{array}{l}\text { Sao Jose do Rio } \\
\text { Preto (SJRP) }\end{array}$ & $\begin{array}{l}\text { São José dos } \\
\text { Campos (SJC) }\end{array}$ & Sorocaba \\
\hline 1 & Sao Carlos & Bauru & RMSP & Campinas & Jundiai & Jundiai & RMSP & RMSP & Rib. Preto & RMSP & Santos & Sao Carlos & SJRP & Campinas & Sorocaba \\
\hline 2 & Campinas & Campinas & RMSP & Campinas & RMSP & RMSP & RMSP & Campinas & RMSP & RMSP & RMSP & Campinas & RMSP & RMSP & RMSP \\
\hline 3 & RMSP & SJRP & RMSP & Campinas & RMSP & RMSP & RMSP & Campinas & Rib. Preto & RMSP & Campinas & Campinas & Campinas & RMSP & RMSP \\
\hline 4 & Campinas & Campinas & Sorocaba & Campinas & Campinas & Campinas & SJRP & RMSP & Campinas & RMSP & RMSP & Campinas & Campinas & SJRP & Campinas \\
\hline 5 & RMSP & Campinas & Campinas & Campinas & RMSP & RMSP & Campinas & RMSP & SJRP & RMSP & RMSP & RMSP & Campinas & RMSP & Santos \\
\hline 6 & Santos & RMSP & Campinas & Campinas & RMSP & RMSP & Campinas & RMSP & Santos & RMSP & RMSP & RMSP & RMSP & RMSP & SJRP \\
\hline 7 & RMSP & RMSP & RMSP & Campinas & RMSP & RMSP & Campinas & Campinas & Campinas & RMSP & Campinas & RMSP & RMSP & RMSP & RMSP \\
\hline 8 & Campinas & Sao Carlos & RMSP & SJRP & RMSP & RMSP & RMSP & RMSP & RMSP & Campinas & RMSP & RMSP & RMSP & RMSP & RMSP \\
\hline 9 & RMSP & Santos & Campinas & RMSP & Campinas & Campinas & RMSP & RMSP & RMSP & RMSP & RMSP & RMSP & Campinas & RMSP & Campinas \\
\hline 10 & Campinas & RMSP & Santos & RMSP & RMSP & RMSP & Bauru & RMSP & Campinas & RMSP & RMSP & Campinas & RMSP & RMSP & Campinas \\
\hline 11 & SJRP & RMSP & Rib. Preto & Jundiai & RMSP & RMSP & RMSP & Rib. Preto & RMSP & RMSP & Campinas & RMSP & RMSP & RMSP & RMSP \\
\hline 12 & Rib. Preto & RMSP & Ba uru & RMSP & Campinas & Campinas & Rib. Preto & Bauru & Sao Carlos & RMSP & SJRP & RMSP & RMSP & RMSP & RMSP \\
\hline 13 & Rib. Preto & RMSP & Sao Carlos & RMSP & RMSP & RMSP & RMSP & RMSP & RMSP & Campinas & RMSP & Santos & Sao Carlos & Santos & Campinas \\
\hline 15 & RMSP & Campinas & RMSP & Santos & Campinas & Campinas & Campinas & Santos & Campinas & Campinas & Rib. Preto & RMSP & Rib. Preto & RMSP & RMSP \\
\hline 16 & RMSP & Rib. Preto & RMSP & RMSP & Santos & Santos & Rib. Preto & RMSP & RMSP & Campinas & RMSP & Campinas & RMSP & Rib. Preto & Rib. Preto \\
\hline 17 & Campinas & RMSP & RMSP & RMSP & RMSP & RMSP & Sao Carlos & SJRP & RMSP & RMSP & RMSP & Rib. Preto & Rib. Preto & Campinas & RMSP \\
\hline 18 & RMSP & Campinas & RMSP & RMSP & Sao Carlos & Sao Carlos & RMSP & Sao Carlos & RMSP & Santos & Campinas & RMSP & RMSP & Campinas & RMSP \\
\hline 19 & RMSP & RMSP & Rib. Preto & RMSP & Campinas & Campinas & RMSP & Campinas & RMSP & RMSP & RMSP & RMSP & Ba uru & Campinas & Campinas \\
\hline 20 & RMSP & Campinas & SJRP & RMSP & RMSP & RMSP & Campinas & Campinas & RMSP & Rib. Preto & Sao Carlos & RMSP & Campinas & Sao Carlos & RMSP \\
\hline 21 & RMSP & Sorocaba & Campinas & Rib. Preto & Rib. Preto & Rib. Preto & RMSP & RMSP & Campinas & Campinas & Sorocaba & Campinas & RMSP & Rib. Preto & Rib. Preto \\
\hline 22 & Campinas & RMSP & RMSP & RMSP & Bauru & Bauru & Campinas & RMSP & Bauru & Jundiai & Rib. Preto & Bauru & RMSP & Sorocaba & RMSP \\
\hline 23 & RMSP & RMSP & Campinas & RMSP & Campinas & Campinas & Sorocaba & Campinas & RMSP & Sao Carlos & Campinas & Rib. Preto & Campinas & Bauru & RMSP \\
\hline 24 & RMSP & Campinas & RMSP & Sorocaba & Sorocaba & Sorocaba & Campinas & RMSP & Jundiai & Rib. Preto & RMSP & Sorocaba & RMSP & RMSP & Jundiai \\
\hline 25 & Campinas & Rib. Preto & Campinas & Bauru & RMSP & RMSP & RMSP & Sorocaba & RMSP & Bauru & Jundiai & RMSP & RMSP & Jundiai & RMSP \\
\hline 26 & Sorocaba & RMSP & RMSP & Rib. Preto & Campinas & Campinas & RMSP & RMSP & Sorocaba & Sorocaba & Bauru & RMSP & Campinas & Campinas & Campinas \\
\hline 27 & RMSP & Jundiai & Campinas & RMSP & Rib. Preto & Rib. Preto & RMSP & Campinas & RMSP & Campinas & Campinas & Campinas & Jundiai & RMSP & Campinas \\
\hline 28 & Jundiai & RMSP & Jundiai & RMSP & RMSP & RMSP & Jundiai & Jundiai & Campinas & Campinas & Campinas & Jundiai & Sorocaba & Campinas & Bauru \\
\hline
\end{tabular}

Fonte: TSE. Elaboração Própria. 


\begin{tabular}{|c|c|c|c|c|c|c|c|c|c|c|c|c|c|c|c|}
\hline $\begin{array}{l}\text { Posição na } \\
\text { lista }\end{array}$ & Araraquara & Bauru & Botucatu & Campinas & Jundiai & Marilia & Ourinhos & $\begin{array}{c}\text { Presidente } \\
\text { Prudente } \\
\text { (Pres.Prudte.) }\end{array}$ & $\begin{array}{c}\text { Ribeirao } \\
\text { Preto (Rib. } \\
\text { Preto) }\end{array}$ & RMSP & Santos & São Carlos & $\begin{array}{l}\text { Sao Jose do } \\
\text { Rio Preto } \\
\text { (SJRP) }\end{array}$ & $\begin{array}{l}\text { São José } \\
\text { dos Campos } \\
\text { (SJC) }\end{array}$ & Sorocaba \\
\hline 2 & Rib.Preto & RMSP & Sorocaba & Campinas & RMSP & RMSP & RMSP & Campinas & RMSP & RMSP & Santos & Campinas & RMSP & RMSP & Sorocaba \\
\hline 3 & Campinas & Sorocaba & Sorocaba & Campinas & Campinas & Campinas & Campinas & RMSP & RMSP & RMSP & Santos & Rib.Preto & Campinas & Campinas & RMSP \\
\hline 4 & RMSP & RMSP & Rib.Preto & Campinas & Campinas & Campinas & Sorocaba & Campinas & Campinas & Sorocaba & RMSP & RMSP & RMSP & Sorocaba & RMSP \\
\hline 5 & RMSP & Sao Carlos & RMSP & Campinas & Sorocaba & Sorocaba & RMSP & RMSP & Campinas & RMSP & RMSP & Sorocaba & Rib.Preto & RMSP & Sorocaba \\
\hline 6 & Jundiai & Campinas & RMSP & RMSP & RMSP & RMSP & RMSP & Sa o Carlos & RMSP & RMSP & Campinas & RMSP & SJC & RMSP & RMSP \\
\hline 7 & RMSP & Rib.Preto & RMSP & RMSP & RMSP & RMSP & RMSP & RMSP & Sao Carlos & RMSP & Sorocaba & RMSP & Sorocaba & RMSP & RMSP \\
\hline 8 & RMSP & RMSP & Campinas & RMSP & RMSP & RMSP & SJC & Rib.Preto & RMSP & RMSP & RMSP & RMSP & RMSP & Campinas & RMSP \\
\hline 9 & RMSP & Sorocaba & Campinas & RMSP & RMSP & RMSP & RMSP & RMSP & Campinas & RMSP & RMSP & RMSP & RMSP & RMSP & RMSP \\
\hline 10 & Campinas & RMSP & Sorocaba & RMSP & RMSP & RMSP & Campinas & SJC & Sorocaba & Campinas & RMSP & Campinas & Sorocaba & RMSP & Campinas \\
\hline 11 & Sorocaba & RMSP & RMSP & Sao Carlos & Sorocaba & Sorocaba & RMSP & RMSP & Campinas & RMSP & Sorocaba & RMSP & Sao Carlos & RMSP & Campinas \\
\hline 13 & RMSP & Campinas & RMSP & RMSP & RMSP & RMSP & RMSP & RMSP & RMSP & RMSP & RMSP & SJC & Campinas & Campinas & RMSP \\
\hline 14 & Campinas & Santos & RMSP & Sorocaba & RMSP & RMSP & Rib.Preto & Campinas & Sorocaba & RMSP & Campinas & RMSP & Campinas & Santos & RMSP \\
\hline 15 & RMSP & Campinas & Campinas & Sorocaba & Campinas & Campinas & Sorocaba & RMSP & $\mathrm{SJC}$ & Campinas & Sorocaba & Santos & RMSP & Sao Carlos & RMSP \\
\hline 16 & Sorocaba & RMSP & RMSP & RMSP & SJC & SJC & RMSP & Campinas & RMSP & Campinas & RMSP & Campinas & RMSP & RMSP & RMSP \\
\hline 17 & RMSP & RMSP & RMSP & RMSP & Campinas & Campinas & RMSP & RMSP & RMSP & Campinas & RMSP & Jundiai & Santos & Sorocaba & Sao Carlos \\
\hline 18 & SJC & RMSP & RMSP & RMSP & Sao Carlos & Sao Carlos & Sao Carlos & Campinas & Campinas & Sorocaba & Sao Carlos & Campinas & Sorocaba & Rib.Preto & RMSP \\
\hline 19 & Santos & RMSP & Campinas & $\mathrm{SJC}$ & RMSP & RMSP & Santos & RMSP & RMSP & $\mathrm{SJC}$ & $\mathrm{SJC}$ & RMSP & RMSP & RMSP & Rib.Preto \\
\hline 20 & Sorocaba & Sorocaba & Santos & RMSP & Santos & Santos & RMSP & Santos & Santos & Sao Carlos & RMSP & Campinas & Campinas & Sorocaba & Campinas \\
\hline 21 & RMSP & Campinas & Sao Carlos & Jundiai & Rib.Preto & Rib.Preto & Campinas & RMSP & Sorocaba & Rib.Preto & RMSP & RMSP & RMSP & Jundiai & SJC \\
\hline 22 & Campinas & Campinas & RMSP & Santos & Campinas & Campinas & Campinas & Sorocaba & RMSP & Santos & Campinas & Sorocaba & RMSP & Campinas & RMSP \\
\hline 23 & Campinas & RMSP & RMSP & Sorocaba & Sorocaba & Sorocaba & Campinas & Sorocaba & Santos & Santos & Rib.Preto & RMSP & RMSP & Campinas & Campinas \\
\hline 24 & RMSP & Jundiai & Campinas & RMSP & Santos & Santos & Jundiai & RMSP & RMSP & Sorocaba & Campinas & Santos & Santos & Santos & Campinas \\
\hline 25 & Santos & RMSP & Santos & Santos & RMSP & RMSP & Santos & Santos & RMSP & Campinas & RMSP & RMSP & RMSP & RMSP & Jundiai \\
\hline 26 & RMSP & Santos & Jundiai & RMSP & RMSP & RMSP & RMSP & Jundiai & Jundiai & Jundiai & Jundiai & RMSP & Jundiai & RMSP & Santos \\
\hline
\end{tabular}




\begin{tabular}{|c|c|c|c|c|c|c|c|c|c|c|c|c|c|c|c|}
\hline $\begin{array}{l}\text { Posição na } \\
\text { lista }\end{array}$ & Araraquara & Bauru & Botucatu & Campinas & Jundiai & Marilia & Ourinhos & $\begin{array}{c}\text { Presidente } \\
\text { Prudente } \\
\text { (Pres.Prudte.) }\end{array}$ & $\begin{array}{c}\text { Ribeirao } \\
\text { Preto (Rib. } \\
\text { Preto) }\end{array}$ & RMSP & Santos & São Carlos & $\begin{array}{l}\text { Sao Jose do } \\
\text { Rio Preto } \\
\text { (SJRP) }\end{array}$ & $\begin{array}{l}\text { São José } \\
\text { dos Campos } \\
\text { (SJC) }\end{array}$ & Sorocaba \\
\hline 2 & RMSP & RMSP & Sorocaba & Campinas & RMSP & RMSP & Campinas & RMSP & SJRP & RMSP & RMSP & Campinas & SJRP & SJRP & Sorocaba \\
\hline 3 & Campinas & Sao Carlos & RMSP & Campinas & Campinas & Campinas & RMSP & Campinas & Sao Carlos & RMSP & RMSP & Rib. Preto & RMSP & Santos & RMSP \\
\hline 4 & SJRP & RMSP & RMSP & Campinas & RMSP & RMSP & RMSP & Campinas & Campinas & RMSP & RMSP & SJRP & Campinas & RMSP & RMSP \\
\hline 5 & Rib. Preto & SJRP & Campinas & RMSP & RMSP & Campinas & RMSP & SJRP & RMSP & RMSP & RMSP & RMSP & RMSP & RMSP & RMSP \\
\hline 6 & RMSP & Campinas & RMSP & RMSP & RMSP & SJRP & SJRP & Sao Carlos & Campinas & RMSP & RMSP & Campinas & Sao Carlos & RMSP & RMSP \\
\hline 7 & Jundiai & RMSP & SJRP & RMSP & RMSP & RMSP & RMSP & RMSP & RMSP & RMSP & RMSP & RMSP & Rib. Preto & Jundiai & Jundiai \\
\hline 8 & Campinas & Rib. Preto & Rib. Preto & SJRP & SJRP & Rib. Preto & RMSP & Campinas & Campinas & RMSP & RMSP & Jundiai & Campinas & RMSP & Campinas \\
\hline 9 & RMSP & RMSP & Sorocaba & Jundiai & RMSP & RMSP & Sao Carlos & RMSP & RMSP & SJRP & SJRP & RMSP & RMSP & Campinas & RMSP \\
\hline 10 & RMSP & RMSP & RMSP & Rib. Preto & RMSP & Sao Carlos & RMSP & RMSP & SJC & RMSP & Jundiai & RMSP & Campinas & RMSP & SJRP \\
\hline 11 & RMSP & Campinas & SJC & RMSP & Campinas & Campinas & Rib. Preto & RMSP & RMSP & RMSP & Campinas & Campinas & RMSP & RMSP & RMSP \\
\hline 13 & Campinas & RMSP & Bauru & Sao Carlos & RMSP & Pres.Prudte & RMSP & RMSP & RMSP & Jundiai & RMSP & RMSP & Campinas & Campinas & RMSP \\
\hline 14 & RMSP & RMSP & RMSP & RMSP & Campinas & Campinas & Bauru & RMSP & RMSP & Campinas & Campinas & RMSP & RMSP & RMSP & RMSP \\
\hline 15 & Santos & RMSP & Sao Carlos & RMSP & RMSP & Santos & Campinas & RMSP & RMSP & Campinas & Campinas & RMSP & Santos & RMSP & Campinas \\
\hline 16 & RMSP & RMSP & RMSP & Santos & SJC & Bauru & Campinas & Campinas & RMSP & Campinas & Sao Carlos & Campinas & RMSP & RMSP & RMSP \\
\hline 17 & SJC & Campinas & RMSP & RMSP & RMSP & RMSP & Campinas & RMSP & RMSP & Santos & RMSP & SJC & RMSP & RMSP & RMSP \\
\hline 18 & RMSP & SJC & RMSP & RMSP & Sao Carlos & RMSP & SJC & Rib. Preto & Campinas & Campinas & Sorocaba & RMSP & RMSP & Campinas & RMSP \\
\hline 19 & Campinas & Santos & RMSP & SJC & Campinas & RMSP & RMSP & Jundiai & Santos & SJC & RMSP & Santos & Pres.Prudte & Campinas & Sao Carlos \\
\hline 20 & RMSP & Campinas & Jundiai & RMSP & Santos & RMSP & Pres.Prudte & SJC & RMSP & Sao Carlos & Campinas & RMSP & RMSP & Sao Carlos & Rib. Preto \\
\hline 21 & Bauru & RMSP & RMSP & Bauru & Rib. Preto & SJC & RMSP & RMSP & Jundiai & Rib. Preto & SJC & RMSP & Jundiai & Rib. Preto & Santos \\
\hline 22 & RMSP & Pres.Prudte & Campinas & Sorocaba & Sorocaba & RMSP & Sorocaba & RMSP & Sorocaba & Sorocaba & Sorocaba & Bauru & Sorocaba & Bauru & SJC \\
\hline 23 & Sorocaba & Jundiai & Santos & RMSP & Sorocaba & Sorocaba & Santos & Bauru & Bauru & Bauru & Rib. Preto & Sorocaba & Bauru & Sorocaba & Bauru \\
\hline 24 & Pres.Prudte & Sorocaba & Pres.Prudte & Sorocaba & Bauru & Jundiai & Jundiai & Sorocaba & Pres.Prudte & Sorocaba & Pres.Prudte & Sorocaba & RMSP & Sorocaba & Campinas \\
\hline 25 & Sorocaba & Sorocaba & Campinas & Pres.Prudte & Pres.Prudte & Sorocaba & Sorocaba & Sorocaba & Sorocaba & Pres.Prudte & Bauru & Pres.Prudte & Sorocaba & Pres.Prudte & Pres.Prudte \\
\hline
\end{tabular}




\begin{tabular}{|c|c|c|c|c|c|c|c|c|c|c|c|c|c|c|c|}
\hline $\begin{array}{l}\text { Posição na } \\
\text { lista }\end{array}$ & Araraquara & Bauru & Botucatu & Campinas & Jundiai & Marilia & Ourinhos & $\begin{array}{c}\text { Presidente } \\
\text { Prudente } \\
\text { (Pres.Prudte.) }\end{array}$ & $\begin{array}{c}\text { Ribeirao } \\
\text { Preto (Rib. } \\
\text { Preto) }\end{array}$ & RMSP & Santos & São Carlos & $\begin{array}{c}\text { Sao Jose do } \\
\text { Rio Preto } \\
\text { (SJRP) }\end{array}$ & $\begin{array}{l}\text { São José } \\
\text { dos Campos } \\
\text { (SJC) }\end{array}$ & Sorocaba \\
\hline 2 & Rib. Preto & Campinas & RMSP & Campinas & Campinas & Santos & RMSP & Campinas & Campinas & RMSP & Santos & Rib. Preto & Campinas & Santos & Santos \\
\hline 3 & Sao Carlos & Campinas & Rib. Preto & Campinas & RMSP & RMSP & RMSP & Rib. Preto & Sao Carlos & RMSP & RMSP & Campinas & Rib. Preto & RMSP & RMSP \\
\hline 4 & RMSP & Sao Carlos & RMSP & Campinas & RMSP & Campinas & RMSP & Santos & RMSP & RMSP & RMSP & Campinas & Campinas & Campinas & RMSP \\
\hline 5 & Jundiai & Rib. Preto & Campinas & RMSP & RMSP & Campinas & Campinas & RMSP & RMSP & RMSP & Rib. Preto & RMSP & Campinas & RMSP & Jundiai \\
\hline 6 & Campinas & Campinas & Campinas & RMSP & Campinas & Rib. Preto & Santos & RMSP & Campinas & Santos & RMSP & Campinas & Campinas & RMSP & RMSP \\
\hline 7 & Campinas & Sorocaba & RMSP & Jundiai & Campinas & Campinas & Campinas & Campinas & SJC & Campinas & Campinas & RMSP & RMSP & Campinas & RMSP \\
\hline 8 & RMSP & RMSP & Campinas & Rib. Preto & Rib. Preto & RMSP & Rib. Preto & Sao Carlos & Santos & Rib. Preto & Campinas & Santos & Sao Carlos & RMSP & Campinas \\
\hline 9 & Campinas & RMSP & Sorocaba & RMSP & Santos & RMSP & Sao Carlos & Campinas & Campinas & Campinas & RMSP & Campinas & RMSP & Rib. Preto & Campinas \\
\hline 10 & RMSP & Santos & RMSP & RMSP & RMSP & Jundiai & RMSP & RMSP & RMSP & Campinas & Campinas & RMSP & Santos & Jundiai & Campinas \\
\hline 11 & RMSP & Campinas & Jundiai & Sao Carlos & RMSP & Sao Carlos & Sorocaba & Campinas & Jundiai & Jundiai & RMSP & RMSP & RMSP & Campinas & Rib. Preto \\
\hline 13 & SJC & SJC & Santos & SJC & SJC & Sorocaba & Santos & Sorocaba & Campinas & Campinas & Sao Carlos & SJC & SJC & Sao Carlos & RMSP \\
\hline 14 & Santos & Santos & SJC & Sorocaba & Sao Carlos & Campinas & SJC & RMSP & Santos & Sao Carlos & Jundiai & Santos & Santos & Campinas & Santos \\
\hline 15 & Santos & RMSP & Campinas & RMSP & Santos & Pres.Prudte & Pres.Prudte & SJC & Pres.Prudte & SJC & SJC & RMSP & RMSP & Sorocaba & Sao Carlos \\
\hline 16 & RMSP & RMSP & Sao Carlos & Santos & Sorocaba & SJC & Campinas & Jundiai & Sorocaba & Sorocaba & Sorocaba & Sorocaba & Pres.Prudte & RMSP & SJC \\
\hline 17 & Pres.Prudte & Pres.Prudte & Pres.Prudte & Pres.Prudte & Pres.Prudte & Santos & Jundiai & Santos & RMSP & Pres.Prudte & Pres.Prudte & Pres.Prudte & Sorocaba & Pres.Prudte & Pres.Prudte \\
\hline
\end{tabular}

Fonte: TSE. Elaboração Própria. 
Alocação regional dos candidatos na lista por região e posição na lista (votos) - PT 2002

\begin{tabular}{|c|c|c|c|c|c|c|c|c|c|c|c|c|c|c|c|}
\hline $\begin{array}{l}\text { Posição na } \\
\text { lista }\end{array}$ & Araraquara & Bauru & Botucatu & Campinas & Jundiai & Marilia & Ourinhos & $\begin{array}{c}\text { Presidente } \\
\text { Prudente } \\
\text { (Pres.Prudte.) }\end{array}$ & $\begin{array}{c}\text { Ribeirao } \\
\text { Preto (Rib. } \\
\text { Preto) }\end{array}$ & RMSP & Santos & São Carlos & $\begin{array}{l}\text { Sao Jose do } \\
\text { Rio Preto } \\
\text { (SJRP) }\end{array}$ & $\begin{array}{l}\text { São José } \\
\text { dos } \\
\text { Campos } \\
\text { (SJC) }\end{array}$ & Sorocaba \\
\hline 1 & RMSP & RMSP & RMSP & Campinas & Jundiai & Jundiai & RMSP & RMSP & RMSP & RMSP & Santos & RMSP & RMSP & SJC & Sorocaba \\
\hline 2 & RMSP & RMSP & Sorocaba & RMSP & RMSP & RMSP & RMSP & SJRP & Rib. Preto & RMSP & Santos & RMSP & SJRP & RMSP & RMSP \\
\hline 3 & RMSP & RMSP & RMSP & Campinas & RMSP & RMSP & RMSP & RMSP & Rib. Preto & RMSP & RMSP & RMSP & Campinas & RMSP & RMSP \\
\hline 4 & RMSP & RMSP & RMSP & Campinas & RMSP & RMSP & RMSP & RMSP & RMSP & RMSP & RMSP & Sorocaba & RMSP & RMSP & RMSP \\
\hline 5 & RMSP & Campinas & RMSP & RMSP & RMSP & RMSP & RMSP & RMSP & RMSP & RMSP & RMSP & RMSP & RMSP & RMSP & RMSP \\
\hline 6 & RMSP & RMSP & RMSP & RMSP & RMSP & RMSP & RMSP & RMSP & RMSP & RMSP & RMSP & RMSP & RMSP & RMSP & RMSP \\
\hline 7 & RMSP & RMSP & RMSP & Campinas & RMSP & RMSP & RMSP & RMSP & RMSP & RMSP & RMSP & RMSP & RMSP & RMSP & RMSP \\
\hline 8 & RMSP & RMSP & RMSP & RMSP & RMSP & RMSP & Jundiai & RMSP & RMSP & RMSP & RMSP & RMSP & RMSP & Campinas & Campinas \\
\hline 9 & RMSP & RMSP & RMSP & RMSP & RMSP & RMSP & RMSP & Jundiai & RMSP & RMSP & Campinas & RMSP & RMSP & RMSP & RMSP \\
\hline 10 & Jundiai & RMSP & RMSP & RMSP & RMSP & RMSP & SJRP & RMSP & Campinas & RMSP & RMSP & RMSP & RMSP & Campinas & Jundiai \\
\hline 11 & RMSP & RMSP & RMSP & RMSP & RMSP & RMSP & RMSP & RMSP & RMSP & RMSP & RMSP & RMSP & RMSP & RMSP & RMSP \\
\hline 12 & RMSP & RMSP & RMSP & RMSP & RMSP & RMSP & RMSP & RMSP & RMSP & RMSP & RMSP & Rib. Preto & RMSP & RMSP & RMSP \\
\hline 13 & SJRP & RMSP & RMSP & Jundiai & RMSP & RMSP & RMSP & RMSP & RMSP & RMSP & RMSP & Campinas & RMSP & Sorocaba & Campinas \\
\hline 14 & RMSP & RMSP & RMSP & RMSP & Campinas & Campinas & Sorocaba & Sorocaba & SJRP & RMSP & RMSP & RMSP & RMSP & RMSP & RMSP \\
\hline 15 & RMSP & Campinas & RMSP & RMSP & Santos & Santos & Campinas & Campinas & RMSP & RMSP & RMSP & Santos & Sorocaba & RMSP & RMSP \\
\hline 16 & Rib. Preto & Jundiai & Campinas & RMSP & RMSP & RMSP & RMSP & RMSP & RMSP & RMSP & Campinas & Campinas & Campinas & Santos & RMSP \\
\hline 17 & Sorocaba & RMSP & Santos & RMSP & Campinas & Campinas & RMSP & Campinas & RMSP & RMSP & RMSP & RMSP & RMSP & Jundiai & Campinas \\
\hline 18 & Campinas & RMSP & Jundiai & Santos & Campinas & Campinas & Santos & Campinas & Campinas & Campinas & RMSP & Jundiai & Jundiai & RMSP & Santos \\
\hline 19 & RMSP & Campinas & Rib. Preto & RMSP & RMSP & RMSP & RMSP & Santos & Santos & Campinas & Sorocaba & RMSP & RMSP & Campinas & RMSP \\
\hline 20 & Santos & Santos & RMSP & RMSP & RMSP & RMSP & Rib. Preto & Santos & Sorocaba & Santos & RMSP & Rib. Preto & RMSP & Santos & Campinas \\
\hline 21 & Campinas & Sorocaba & SJRP & RMSP & RMSP & RMSP & RMSP & RMSP & RMSP & Jundiai & RMSP & Campinas & Campinas & RMSP & RMSP \\
\hline 22 & Rib. Preto & Santos & Campinas & SJC & Sorocaba & Sorocaba & RMSP & Rib. Preto & Santos & Santos & Jundiai & SJRP & Rib. Preto & Rib. Preto & RMSP \\
\hline 23 & RMSP & SJRP & RMSP & Santos & SJC & SJC & Rib. Preto & SJC & SJC & Sorocaba & RMSP & Campinas & Santos & RMSP & RMSP \\
\hline 24 & Campinas & Rib. Preto & SJC & Sorocaba & Santos & Santos & Campinas & RMSP & Jundiai & SJC & Rib. Preto & RMSP & RMSP & SJRP & SJRP \\
\hline 25 & SJC & Campinas & Rib. Preto & Rib. Preto & SJRP & SJRP & Santos & RMSP & RMSP & Campinas & SJC & Santos & Rib. Preto & RMSP & Santos \\
\hline 26 & Santos & RMSP & Campinas & RMSP & Campinas & Campinas & Campinas & Rib. Preto & Campinas & Rib. Preto & Rib. Preto & RMSP & Santos & RMSP & SJC \\
\hline 27 & RMSP & SJC & Santos & RMSP & Rib. Preto & Rib. Preto & RMSP & Campinas & RMSP & Campinas & Campinas & SJC & Campinas & RMSP & RMSP \\
\hline 28 & RMSP & Rib. Preto & Campinas & SJRP & RMSP & RMSP & SJC & RMSP & RMSP & Rib. Preto & Campinas & RMSP & RMSP & Rib. Preto & Rib. Preto \\
\hline 29 & Campinas & RMSP & RMSP & Rib. Preto & Rib. Preto & Rib. Preto & Campinas & RMSP & Campinas & SJRP & SJRP & RMSP & SJC & Campinas & Rib. Preto \\
\hline
\end{tabular}




\begin{tabular}{|c|c|c|c|c|c|c|c|c|c|c|c|c|c|c|c|}
\hline $\begin{array}{l}\text { Posição na } \\
\text { lista }\end{array}$ & Araraquara & Bauru & Botucatu & Campinas & Jundiai & Marilia & Ourinhos & $\begin{array}{c}\text { Presidente } \\
\text { Prudente } \\
\text { (Pres.Prudte.) }\end{array}$ & $\begin{array}{c}\text { Ribeirao } \\
\text { Preto (Rib. } \\
\text { Preto) }\end{array}$ & RMSP & Santos & São Carlos & $\begin{array}{l}\text { Sao Jose do } \\
\text { Rio Preto } \\
\text { (SJRP) }\end{array}$ & $\begin{array}{l}\text { São José } \\
\text { dos } \\
\text { Campos } \\
\text { (SJC) }\end{array}$ & Sorocaba \\
\hline 1 & Rib.Preto & RMSP & RMSP & Campinas & Jundiai & Jundiai & RMSP & RMSP & Rib.Preto & RMSP & Santos & RMSP & RMSP & SJC & Sorocaba \\
\hline 2 & RMSP & RMSP & Sorocaba & Campinas & RMSP & RMSP & RMSP & RMSP & Rib.Preto & RMSP & Santos & RMSP & Rib.Preto & RMSP & Sorocaba \\
\hline 3 & RMSP & RMSP & RMSP & RMSP & RMSP & RMSP & RMSP & RMSP & RMSP & RMSP & RMSP & Rib.Preto & Campinas & RMSP & $\mathrm{RMSP}$ \\
\hline 4 & RMSP & Campinas & RMSP & RMSP & RMSP & RMSP & RMSP & RMSP & RMSP & RMSP & RMSP & RMSP & RMSP & RMSP & RMSP \\
\hline 5 & Rib.Preto & RMSP & Sorocaba & RMSP & RMSP & RMSP & Rib.Preto & RMSP & RMSP & RMSP & RMSP & RMSP & RMSP & RMSP & RMSP \\
\hline 6 & RMSP & RMSP & RMSP & Rib.Preto & RMSP & RMSP & RMSP & RMSP & Campinas & RMSP & RMSP & Sorocaba & RMSP & RMSP & RMSP \\
\hline 7 & Campinas & RMSP & RMSP & RMSP & RMSP & RMSP & RMSP & Jundiai & RMSP & RMSP & RMSP & RMSP & RMSP & RMSP & RMSP \\
\hline 8 & RMSP & RMSP & RMSP & RMSP & RMSP & RMSP & Sorocaba & Campinas & RMSP & RMSP & RMSP & RMSP & RMSP & RMSP & Jundiai \\
\hline 9 & RMSP & RMSP & RMSP & Jundiai & Rib.Preto & Rib.Preto & RMSP & RMSP & Santos & RMSP & RMSP & RMSP & RMSP & Rib.Preto & RMSP \\
\hline 10 & RMSP & Campinas & Rib.Preto & RMSP & RMSP & RMSP & RMSP & RMSP & RMSP & RMSP & RMSP & RMSP & RMSP & RMSP & RMSP \\
\hline 11 & RMSP & Jundiai & RMSP & RMSP & Campinas & Campinas & RMSP & Sorocaba & RMSP & RMSP & RMSP & RMSP & RMSP & Campinas & RMSP \\
\hline 12 & RMSP & Rib.Preto & Campinas & RMSP & RMSP & RMSP & RMSP & RMSP & RMSP & Rib.Preto & RMSP & RMSP & RMSP & RMSP & RMSP \\
\hline 13 & RMSP & RMSP & Jundiai & RMSP & RMSP & RMSP & RMSP & RMSP & RMSP & RMSP & RMSP & Campinas & RMSP & Santos & RMSP \\
\hline 14 & Jundiai & RMSP & RMSP & RMSP & RMSP & RMSP & RMSP & Rib.Preto & RMSP & RMSP & RMSP & RMSP & Campinas & Sorocaba & Rib.Preto \\
\hline 15 & RMSP & RMSP & RMSP & RMSP & RMSP & RMSP & RMSP & Santos & RMSP & RMSP & Rib.Preto & Campinas & Rib.Preto & RMSP & RMSP \\
\hline 16 & RMSP & RMSP & RMSP & RMSP & RMSP & RMSP & Jundiai & RMSP & RMSP & RMSP & RMSP & Jundiai & RMSP & Campinas & RMSP \\
\hline 17 & RMSP & RMSP & RMSP & SJC & RMSP & RMSP & RMSP & RMSP & RMSP & RMSP & RMSP & RMSP & RMSP & RMSP & RMSP \\
\hline 18 & Campinas & RMSP & RMSP & RMSP & RMSP & RMSP & Santos & RMSP & Jundiai & RMSP & Campinas & RMSP & Jundiai & RMSP & RMSP \\
\hline 19 & RMSP & Sorocaba & RMSP & RMSP & RMSP & RMSP & Sorocaba & RMSP & RMSP & RMSP & RMSP & RMSP & Sorocaba & RMSP & RMSP \\
\hline 20 & Santos & RMSP & RMSP & Sorocaba & Santos & Santos & RMSP & RMSP & RMSP & RMSP & Jundiai & RMSP & SJC & RMSP & Campinas \\
\hline 21 & RMSP & Sorocaba & RMSP & RMSP & Campinas & Campinas & RMSP & Rib.Preto & Campinas & Campinas & RMSP & RMSP & RMSP & RMSP & RMSP \\
\hline 22 & Sorocaba & Santos & RMSP & Santos & Sorocaba & Sorocaba & RMSP & SJC & Santos & Jundiai & Sorocaba & Rib.Preto & RMSP & RMSP & Santos \\
\hline 23 & RMSP & RMSP & Campinas & RMSP & RMSP & RMSP & Campinas & Santos & RMSP & Santos & Campinas & RMSP & RMSP & RMSP & Campinas \\
\hline 24 & Santos & Rib.Preto & RMSP & RMSP & RMSP & RMSP & RMSP & RMSP & Sorocaba & Campinas & RMSP & Santos & Santos & Jundiai & SJC \\
\hline 25 & Sorocaba & RMSP & Santos & Santos & Santos & Santos & Santos & RMSP & RMSP & SJC & RMSP & Santos & Santos & Santos & RMSP \\
\hline 26 & RMSP & RMSP & RMSP & RMSP & SJC & SJC & Rib.Preto & Campinas & Sorocaba & Santos & Rib.Preto & Sorocaba & RMSP & RMSP & RMSP \\
\hline 27 & RMSP & SJC & Santos & Sorocaba & Rib.Preto & Rib.Preto & Campinas & RMSP & RMSP & Sorocaba & Sorocaba & SJC & Sorocaba & Rib.Preto & Rib.Preto \\
\hline 28 & RMSP & Santos & Rib.Preto & RMSP & RMSP & RMSP & RMSP & RMSP & RMSP & Rib.Preto & SJC & RMSP & RMSP & RMSP & Santos \\
\hline 29 & SJC & RMSP & SJC & Rib.Preto & Sorocaba & Sorocaba & SJC & Sorocaba & SJC & Sorocaba & RMSP & RMSP & RMSP & Sorocaba & RMSP \\
\hline
\end{tabular}


Alocação regional dos candidatos na lista por região e posição na lista (votos) - PT 2010

\begin{tabular}{|c|c|c|c|c|c|c|c|c|c|c|c|c|c|c|c|}
\hline $\begin{array}{l}\text { Posição na } \\
\text { lista }\end{array}$ & Araraquara & Bauru & Botucatu & Campinas & Jundiai & Marilia & Ourinhos & $\begin{array}{c}\text { Presidente } \\
\text { Prudente } \\
\text { (Pres.Prudte.) }\end{array}$ & $\begin{array}{c}\text { Ribeirao } \\
\text { Preto (Rib. } \\
\text { Preto) }\end{array}$ & RMSP & Santos & São Carlos & $\begin{array}{l}\text { Sao Jose do } \\
\text { Rio Preto } \\
\text { (SJRP) }\end{array}$ & $\begin{array}{l}\text { São José } \\
\text { dos Campos } \\
\text { (SJC) }\end{array}$ & Sorocaba \\
\hline 2 & RMSP & RMSP & RMSP & RMSP & RMSP & RMSP & RMSP & RMSP & Sao Carlos & RMSP & RMSP & RMSP & SJRP & RMSP & RMSP \\
\hline 3 & RMSP & RMSP & RMSP & Campinas & RMSP & RMSP & RMSP & RMSP & RMSP & RMSP & RMSP & RMSP & RMSP & RMSP & RMSP \\
\hline 4 & RMSP & RMSP & RMSP & RMSP & RMSP & RMSP & RMSP & RMSP & RMSP & RMSP & RMSP & RMSP & RMSP & RMSP & RMSP \\
\hline 6 & RMSP & RMSP & RMSP & RMSP & RMSP & RMSP & RMSP & RMSP & RMSP & RMSP & RMSP & RMSP & RMSP & RMSP & RMSP \\
\hline 7 & RMSP & RMSP & RMSP & Sao Carlos & RMSP & RMSP & RMSP & SJRP & RMSP & RMSP & RMSP & SJRP & RMSP & RMSP & RMSP \\
\hline 8 & SJRP & SJRP & RMSP & RMSP & RMSP & RMSP & RMSP & RMSP & RMSP & RMSP & RMSP & RMSP & Campinas & RMSP & RMSP \\
\hline 9 & RMSP & RMSP & RMSP & RMSP & RMSP & RMSP & RMSP & RMSP & SJRP & RMSP & RMSP & RMSP & RMSP & RMSP & RMSP \\
\hline 10 & RMSP & RMSP & Campinas & RMSP & SJC & RMSP & RMSP & RMSP & RMSP & RMSP & RMSP & RMSP & RMSP & RMSP & RMSP \\
\hline 11 & RMSP & RMSP & Sorocaba & RMSP & RMSP & Sao Carlos & RMSP & Campinas & RMSP & RMSP & RMSP & RMSP & Sao Carlos & RMSP & RMSP \\
\hline 13 & RMSP & RMSP & RMSP & RMSP & Sao Carlos & RMSP & RMSP & RMSP & RMSP & RMSP & RMSP & RMSP & RMSP & RMSP & RMSP \\
\hline 14 & RMSP & RMSP & RMSP & RMSP & Campinas & RMSP & Campinas & RMSP & RMSP & RMSP & RMSP & SJC & RMSP & RMSP & RMSP \\
\hline 15 & Campinas & RMSP & Sao Carlos & RMSP & RMSP & RMSP & RMSP & RMSP & Campinas & RMSP & RMSP & Sorocaba & RMSP & SJRP & RMSP \\
\hline 16 & RMSP & Campinas & RMSP & RMSP & RMSP & Campinas & Sao Carlos & RMSP & RMSP & RMSP & RMSP & RMSP & RMSP & RMSP & RMSP \\
\hline 17 & RMSP & RMSP & RMSP & RMSP & RMSP & RMSP & RMSP & Sao Carlos & RMSP & RMSP & SJRP & Campinas & RMSP & RMSP & SJRP \\
\hline 18 & RMSP & RMSP & RMSP & SJRP & Sorocaba & SJRP & RMSP & RMSP & RMSP & RMSP & RMSP & RMSP & Santos & RMSP & RMSP \\
\hline 19 & Sorocaba & Jundiai & Santos & RMSP & RMSP & Sorocaba & Sorocaba & Sorocaba & RMSP & Campinas & Campinas & RMSP & Sorocaba & Campinas & Campinas \\
\hline 20 & SJC & RMSP & RMSP & Jundiai & RMSP & SJC & SJC & Santos & Santos & SJRP & RMSP & RMSP & RMSP & Sao Carlos & RMSP \\
\hline 21 & Campinas & Sorocaba & SJC & RMSP & RMSP & RMSP & Santos & Jundiai & Sorocaba & SJC & RMSP & RMSP & SJC & RMSP & Sao Carlos \\
\hline 22 & RMSP & Santos & RMSP & SJC & Campinas & Santos & RMSP & RMSP & SJC & Sao Carlos & Sorocaba & Campinas & Campinas & Santos & Campinas \\
\hline 23 & RMSP & RMSP & Campinas & Santos & Santos & RMSP & RMSP & SJC & Campinas & Santos & Sao Carlos & Santos & RMSP & Sorocaba & RMSP \\
\hline 24 & Santos & RMSP & RMSP & Sorocaba & RMSP & RMSP & RMSP & Campinas & RMSP & Sorocaba & Campinas & RMSP & Jundiai & RMSP & SJC \\
\hline 25 & Jundiai & Campinas & RMSP & RMSP & RMSP & Campinas & Campinas & RMSP & Jundiai & Campinas & SJC & RMSP & RMSP & RMSP & Jundiai \\
\hline 26 & RMSP & SJC & Jundiai & RMSP & SJRP & Jundiai & Jundiai & RMSP & RMSP & Jundiai & Jundiai & Jundiai & RMSP & Jundiai & Santos \\
\hline
\end{tabular}




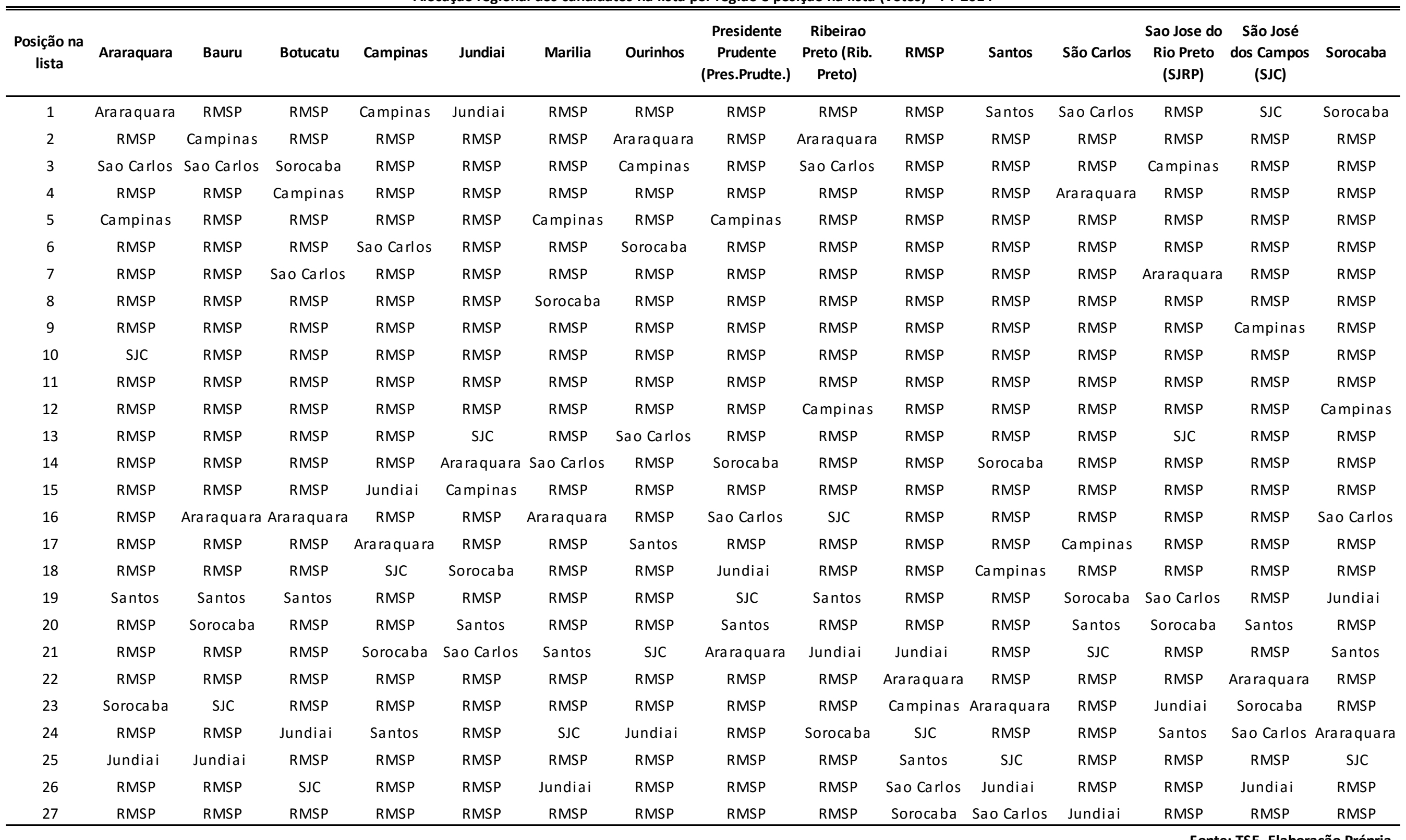


Alocação regional dos candidatos na lista por região e posição na lista (votos) - PSD 2014

\begin{tabular}{|c|c|c|c|c|c|c|c|c|c|c|c|c|c|c|c|}
\hline $\begin{array}{l}\text { Posição na } \\
\text { lista }\end{array}$ & Araraquara & Bauru & Botucatu & Campinas & Jundiai & Marilia & Ourinhos & $\begin{array}{c}\text { Presidente } \\
\text { Prudente } \\
\text { (Pres.Prudte.) }\end{array}$ & $\begin{array}{c}\text { Ribeirao } \\
\text { Preto (Rib. } \\
\text { Preto) }\end{array}$ & RMSP & Santos & São Carlos & $\begin{array}{l}\text { Sao Jose do } \\
\text { Rio Preto } \\
\text { (SJRP) }\end{array}$ & $\begin{array}{l}\text { São José } \\
\text { dos Campos } \\
\text { (SJC) }\end{array}$ & Sorocaba \\
\hline 1 & RMSP & RMSP & Sorocaba & Sorocaba & SJC & Marilia & Marilia & RMSP & Sorocaba & RMSP & Sorocaba & Sorocaba & Sorocaba & RMSP & Sorocaba \\
\hline 2 & Sorocaba & Sorocaba & Sorocaba & Campinas & Sorocaba & Sorocaba & Sorocaba & Sorocaba & Campinas & RMSP & SJC & RMSP & RMSP & Sorocaba & Sorocaba \\
\hline 3 & Sorocaba & Campinas & Marilia & RMSP & Sorocaba & RMSP & SJC & Marilia & RMSP & RMSP & RMSP & Campinas & SJC & SJC & RMSP \\
\hline 4 & SJC & Sorocaba & RMSP & Sorocaba & Campinas & Sorocaba & Sorocaba & SJC & Sorocaba & RMSP & Marilia & Sorocaba & Marilia & RMSP & RMSP \\
\hline 6 & Campinas & SJC & RMSP & Marilia & RMSP & RMSP & RMSP & RMSP & Marilia & RMSP & RMSP & RMSP & Campinas & Sorocaba & RMSP \\
\hline 7 & RMSP & RMSP & Campinas & RMSP & RMSP & RMSP & RMSP & RMSP & SJC & Sorocaba & RMSP & Marilia & RMSP & Campinas & SJC \\
\hline 8 & Marilia & RMSP & SJC & RMSP & RMSP & Campinas & RMSP & RMSP & RMSP & Marilia & RMSP & RMSP & RMSP & RMSP & Marilia \\
\hline 9 & RMSP & RMSP & RMSP & RMSP & Marilia & RMSP & RMSP & RMSP & RMSP & SJC & RMSP & RMSP & RMSP & Marilia & Campinas \\
\hline 10 & RMSP & RMSP & RMSP & RMSP & RMSP & RMSP & Campinas & Campinas & RMSP & Sorocaba & Campinas & RMSP & RMSP & RMSP & RMSP \\
\hline 11 & RMSP & RMSP & RMSP & RMSP & RMSP & RMSP & RMSP & RMSP & RMSP & Campinas & RMSP & RMSP & RMSP & RMSP & RMSP \\
\hline
\end{tabular}

Fonte: TSE. Elaboração Própria. 